


\section{TO THE READER.}

GAUG 17

This book is not in good condition. Please use it carefully.

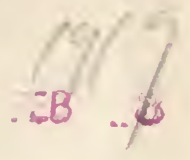

8 JAN 9
"AUE 2

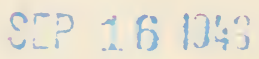

A. Jhir 15

u

ar SEF 30

क6न \& 1

(2) $1 \pi$

300524

3:AR 15
$4=2-5,47$ 




\section{BIG GAME SHOOTING ON THE EQUATOR}




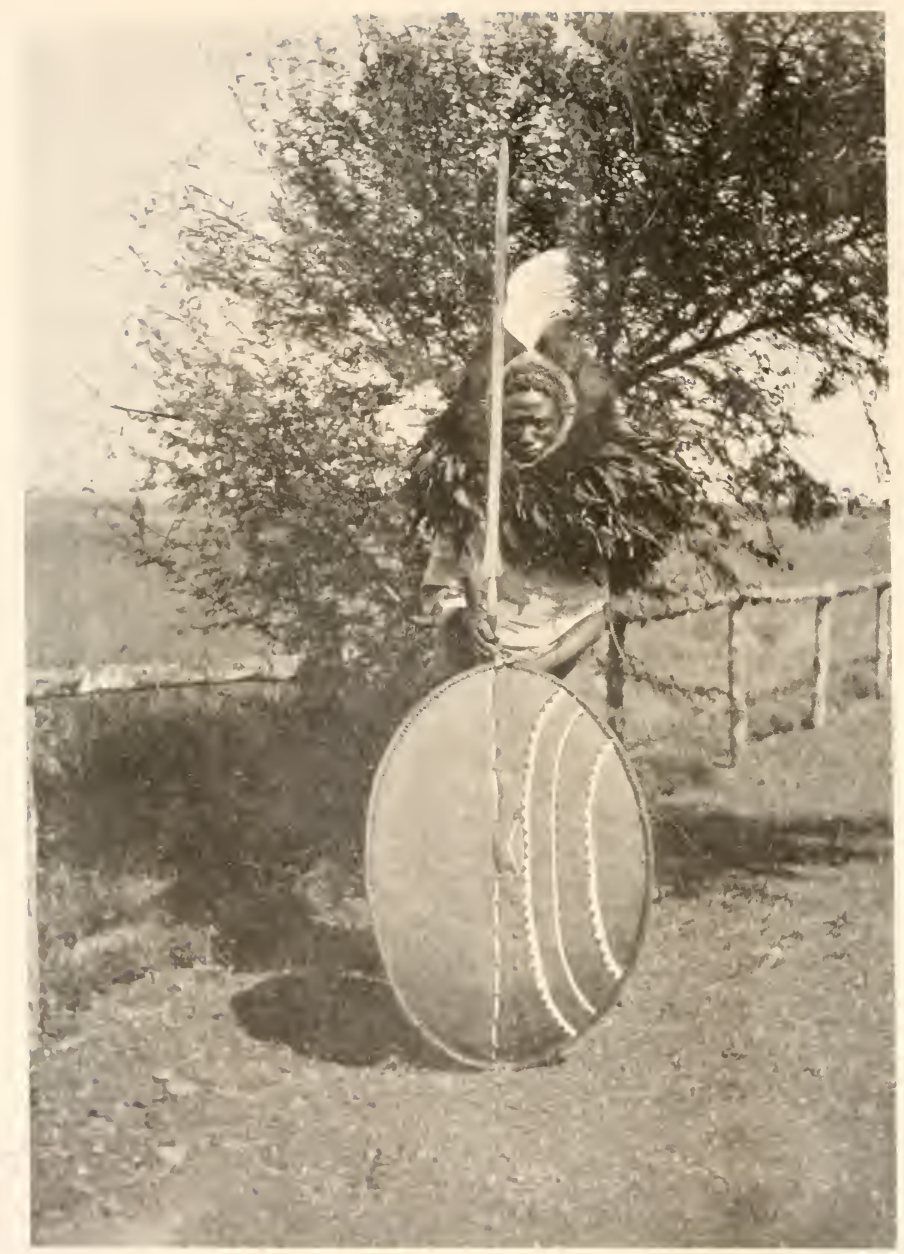

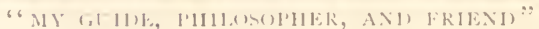




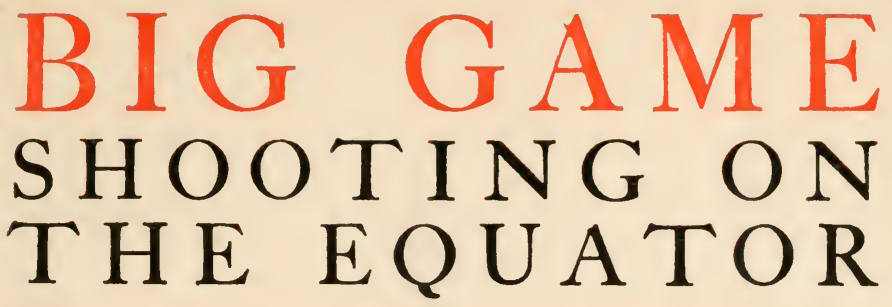

BY CAPTAIN F. A. DICKINSON, F.R.G.S. WITH AN INTRODUCTION BY SIR CHARLES NORTON ELIOT, K.C.M.G. LATE COMMISSIONER FOR BRITISH EAST AFRICA 77 ILLUSTRATIONS REPRODUCEDFROM PHOTOGRAPHS 


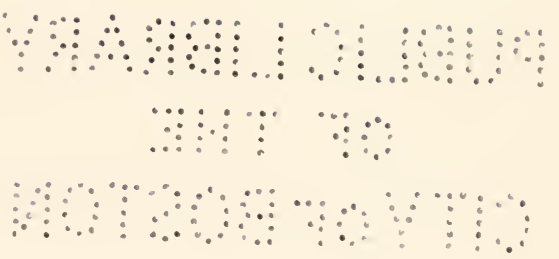

PLYMOUTH: WILLIAM BKENDON AND SON, LTD., PRINTERS 


\section{INTRODUCTION}

YAPTAIN DICKINSON has asked me to write an introduction to his notes on Sport in East Africa, and I have much pleasure in complying with his request, although I am not a sportsman myself and have no qualification for speaking about sport in our Equatorial African possessions. But I know the country well, and can bear witness to the extraordinary and almost incredible quantity of big game which it contains. Tropical Africa is remarkable for the number and variety of large Ungulata contained in its fauna, and all the conditions are favourable to the sportsman and even to the mere sightseer. The country is open, and hence whatever game there is can be seen without difficulty, whereas in neighbouring countries, such as Uganda, it is hidden by forests and high grass; also legislation has intervened in time to stop the havoc wrought by the unrestrained energy of private sportsmen, and reserves of considerable extent have been established within whose precincts no animal may be killed. The Uganda Railway passes through 


\section{Big Game Shooting}

the best known of these reserves, and for almost one hundred miles the traveller may view from the windows of his railway carriage the surprising spectacle of large and beautiful animals which are rarely seen outside zoological gardens feeding freely and without fear close to the railway track. The two most abundant animals are the Zebra, which may be seen in herds which sometimes literally contain thousands, and the Hartebeest or Kongoni, a strongly built antelope of somewhat bovine appearance, with a sloping back. Mingled with this latter is sometimes found the Wildebeest or Gnu, a curious-looking creature which attracts attention not only by its bushy mane but by its strange leaps and capers. Neither Hartebeest nor Wildebeest are remarkable for grace of build or movement, but this is supplied by the beautiful Gazelles, known as Gazella Thomsoni and G. Granti, which are sometimes so plentiful that they cover large tracts of the plain. A pretty sight may occasionally be seen near Naivasha, where the wild gazelles become surrounded by the flocks of native sheep and go on grazing without fear. These antelopes and the zebra, together with ostriches, may nearly always be found on the Athi plains. Rarer, but still sometimes to be seen by those whom fortune favours, are lions, giraffes, and rhinoceros. It is better to see the latter animal from a train than to meet it when marching, for though Captain 


\section{Introduction}

Dickinson endeavours to whitewash its-character, there is no doubt that either from shortness of sight or shortness of temper it has a way of charging caravans, which is not only inconvenient but dangerous. The elephant alone of the larger mammals is rarely visible and, in the East Africa Protectorate at any rate, keeps to the shelter of forests or bushy country; but wherever there is a large sheet of water, and even in some quite small rivers, the nose and ears of the hippopotamus may generally be seen protruding from the surface.

This profusion of animal life can of course be preserved only by the rigid enforcement of the game laws within the area of the reserves, where no animals of any kind may be killed. Outside these reserves sportsmen are allowed to kill a limited amount of game, which is, however, sufficient to provide specimens of all the heads which any one is likely to desire. Besides the species mentioned above the sportsman will probably see Impalah, Oribi, Oryx, Roan, Waterbuck, Waller's Gazelle, and many others. The two most beautiful antelopes, the Greater Kudu and the Sable, are both somewhat rare, but the former is found near Baringo and the latter on the coast near Gazi. Travellers, however, are likely to be attracted by the excellent climate and beautiful scenery of the open country districts, rather than by the tropical jungles of the coast. 


\section{Big Game Shooting}

I hardly venture to offer any opinion as to which are the best localities for sport. When I was in the Protectorate about two years ago, it was generally considered that the greatest variety, if not the greatest quantity of game, was to be found either in the scrub-covered plains between Voi and Taveta, or in the open country between Nakuru and Baringo.

Sport in East Africa can hardly be said to be within the reach of a poor man unless he is a resident, in which case opportunities will occur without much expense; but the traveller must face a certain outlay in connection with the equipment of his caravan, and is warned not to be too Spartan or to run risks of exposure, for, excellent as the climate is, the dangers of both sunstroke and chill are very real and very terrible to the imprudent. Financially East African travelling has this advantage, that you know the expense beforehand. The cost of a caravan can be calculated, and once it is paid for, it is impossible to spend money when on the march.

Captain Dickinson treats not only of sport, but also of the scenery of the Protectorate, which is as remarkable as its fauna. Those who have seen the dome of Kilimanjaro in the evening light, or looked from some neighbouring height across the wide, windy hollows of the Rift Valley or the course of the Kerio River, will understand his enthusiasm for East African landscapes and 


\section{Introduction}

the spell which they cast on all spectators. Much of the charm and grandeur of these views depends on the size of the panorama and cannot be reproduced, but the excellent photographs which Captain Dickinson has taken will go far to give a true impression of these highlands. They are specially interesting because they represent not merely the better-known scenes of the Protectorate, but also remote parts like the AngloGerman boundary and the Laikipia escarpment, which are only now becoming known and which the author has had exceptional opportunities of visiting.

C. ELIOT. 



\section{PREFACE}

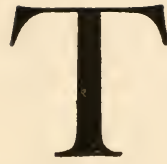

HIS attempt at a book-I would rather call it a series of sketches-is written to try and help young sportsmen who come out to East Africa to find their way round, particularly at the present time, when this part of the world seems to be a most popular paradise for the big-game shooter.

I was very fortunate in being able to get up North with the new Masai Reserves Commission, as I got a good number of my trophies there and then in Laikipia. I was also lucky in being sent out with the Anglo-German Boundary Commission, as the shooting all down the border was wonderful, and, what is more, had never before been touched.

In this book I want to put down ideas of the various kinds of animals that I have come across, that sportsmen who go to East Africa might meet any day of the week-in their proper district, of course-so as to be a sort of guide as to what to do in the pursuit of them.

Another two reasons for this effort are, that, firstly, I fancy there is not an up-to-date book 


\section{Big Game Shooting}

on this part of the world to be had, without going to the trouble of buying a big, heavy volume, which gives, besides the animals one wants, forty thousand other kinds as well that one never meets here. The country is so gaining in popularity every day that it is often impossible to obtain porters for Government purposes, at certain favourite times for shooting-parties, in Nairobi, on account of the numbers of sportsmen in the country who have snapped them up.

Secondly, someof the photographs are good likenesses of the various animals depicted. A photograph cannot lie when a picture is taken in the jungle; at any rate I know that my five by four Kodak doesn't. I have had to borrow some films from my friends, as I stupidly used to forget my camera on occasions at first, and I take this opportunity of expressing my thanks for their kindness.

East Africa is a paradise in more than one sense of the word. The quantity of game in certain parts, easily get-at-able, is absurd. I remember when in Somaliland, before I came here, hearing fellows talking about the amount of game one could see in a day from the windows of the comfortable carriages on the Uganda Railway, which passes through the heart of the game country. I said little, but thought every time, "All men are liars." All I can now say is, if you don't believe it go there and see for yourself, and you will be badly startled. 


\section{Preface}

Of course if one dives off after a certain animal to a beastly, stony, waterless part, one may find it not so much like the Garden of Eden as one expected, even after being warned; but if the shooter does go he will probably get his beast if he makes up his mind to try.

Some parts are a veritable paradise from the scenery and vegetation point of view, and there is game as well in all probability; and there are other places where game is all in all and scenery a minor point.

Let our friend go to the top of the Mau.Plateau and cast his eyes on the forest round him and the misty Rift Valley thousands of feet below him.

He can shoot on the Tana River and have the snow-clad peak of Kenia in view all the time from his base of river scenery and undulating wooded plains.

Again, he might wander about round the forests at the foot of Kilimanjaro, which will not disappoint him; nor will the game either. Kilimanjaro is the highest mountain in Africa, and is worth going a long way to see it as I have from my grass house. I lived on the side of a small hill, and could feel quite frosty, looking over the tropical forest at my feet, steaming with damp and humming with mosquitoes, at Kilimanjaro's double snow-clad top, 19,000 feet above the clouds. Then there are the flowers and the butterflies, 


\section{Big Game Shooting}

which, if one walks about with one's eyes open, are always changing with localities; and the hundred and one details which a lover of nature takes in. I have seen funny little birds, the size of a huge beetle, with tails ten inches long, others bright shot-green or blue, that live on insects. There is an unpleasant kind of tsetse there, and some superfine scorpions. Partridge and guineafowl jostle with one another to clear away from one, and a mile away you can hear the bass grunt of the hippo saying, "Good morning! Sorry I can't stop!" One "lives" in a forest like that amidst birds and beasts, but it rather annoys one's boots. Go there and take it all in.

Having wandered about a bit, through Somaliland and East Africa, I rather fancy I say to myself, "this looks like so-and-so country." For example, on the very morning I wrote this paragraph, I could not help thinking that although it was frightfully wet, as the rains were on, my location looked rather like Lesser Kudu country in a way. I had not gone a mile before I saw a Gerenuk. Now, from Somaliland experience, I knew that they both liked the same kind of ground and are found together, and so would have betted that I should see one at any moment. I was quite right, as next morning I did, and I was not out-of-the-way astonished-I got one a week later a mile from the same place. I don't mean to say that because one sees a nice wooded river, or a rolling open 

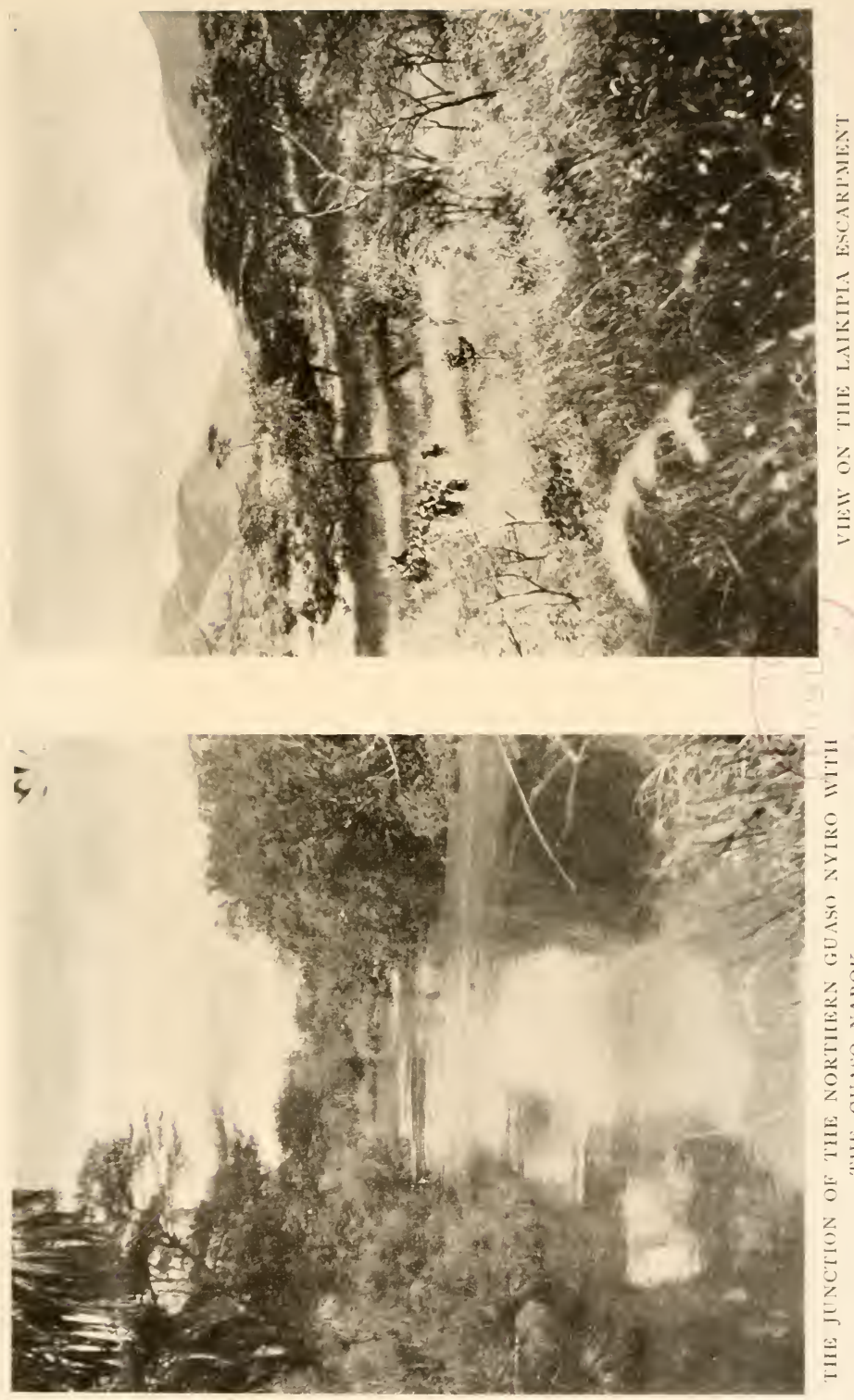

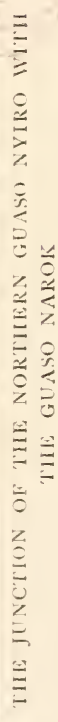





\section{Preface}

plain, one won't think they mean Waterbuck or Hartebeest respectively. Of course they do as a rule, and every one knows it. What I mean is that a man who notices configuration of the country, soil, trees, grass, etc., and thinks where he saw the kind before, and then puts two and two together, may just be able to get a shy, difficult beast, because he remembers that he found it in similar country before, and does not go blundering along and frighten the thing away through not knowing what he might expect.

Unfortunately there is no proper large scale map obtainable to show all the little places in the large districts dealt with; but new maps are announced as coming out immediately, I believe, and can be obtained from the Intelligence Department of the War Office and from the Geographical Society. A very good map of the Anglo-German Boundary has been issued, entitled "Kilimanjaro," but naturally this embraces only a portion of the hunting grounds. 
. 


\section{CONTENTS}

InTRODUCTION

PREFACE . . . . . . . . . $\mathrm{I} 3$

INTROdUctory Chapter . . . . . . 27

In Untrodden Paths . . . . . . . . 48

Elephant (Elephas Africanus) . . . . . 7 I

Rhinoceros (Rhinoceros Bicornis) • . . $\quad 77$

A Red-Letter Day . . . . . . . . 83

Hippopotamus .

Giraffe (Giraffa Camelopardalis) . . . . 92

Lion (Felis Leo) . $\quad . \quad$. $\quad . \quad$. 94

Other Carnivora . . . . . . . . . 97

Greater Kudu (Strepsiceros Kudu) . . . . 100

LESSER KuDU (Strepsiceros Imberbis) . . . . . 103

BeIsa Oryx (Oryx Beisa). . . . . . 106

Fringe-eared Oryx (Oryx Callotis). . . . IO9

Buffalo (Bos Caffer). . . . . . . II

A Buffalo Drive . . . . . . . . 1 I 7

ElaND (Taurotragus Livingstoni) . • . . 125

Roan Antelope (Hippotragus Equinus) . . . 128

Impalah (Epyceros Melampus) . • . . . I3I

Water-Buck (Cobus Ellipsiprymmus and Cobus Defassa

Sing-Sing) . . . . . . . . 135 


\section{Big Game Shooting}

Wildebeest (Connochotes Albojubatus)

Hartebeest (Bubalis Jacksoni. Bubalis Neumanni.

Bubalis Cokei) . . . . . . . . 142

Topi (Damaliscus Jimela) . . . . . . 146

The Zebra (Equus Gréryi and E. Burchelli) . . ${ }_{4} 48$

Bush-Buck (Tragelaphus Scriptus) . . . . I $5^{\mathbf{I}}$

Waller's Gazelle (Lithocranius Walleri) • • . 153

Grant's Gazelle (Gazella Granti) • • • . I56

Roberts's Gazelle (Gazella Granti Robertsi) • $\quad$ I 59

Peters's Gazelle (Gazella Petersi) . . . . I6 I

Thomson's Gazelle (Gazella Thomsoni) • • . ${ }^{16} 6_{3}$

Bohor Reed-Buck (Cervicapra Bohor) . . . ${ }^{1} 6_{5}$

WART-Hog (Phacocharus Africanus) . . . . ${ }^{167}$

Ostrich (Struthio Masaicus) . . . . . . 169

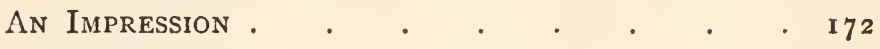

Ways AND MEANS. • . . . . . . 179

Round Lake Natron . . . . . . 210

To Naivasha after Duck and Snipe . . 223

A Day on the German Boundary . • • . 235

The Preservation of Big Game . . . 246

Game Regulations of 1897 . . . . . 260

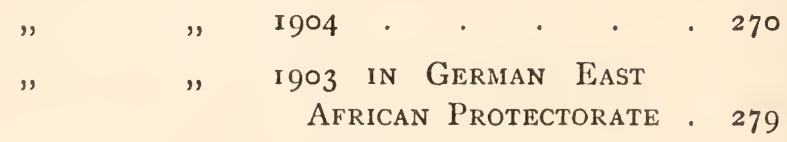




\section{ILLUSTRATIONS}

"My Guide, Philosopher, ANd Friend"

Frontispiece

TO FACE PAGE

The Junction of the Northern Guaso Nyiro with the GUaso NaROK . . . . . . . . . 16 VIEW ON THE LAIKIPIA ESCARPMENT • . . . . I6 A Group of Masai Spearmen . . . . . . . 52 More Masai, showing the various Headdresses • $\quad 52$ Cattle crossing the Ford on the Tana River . . . 56 The Thika-Thika River near its Junction with the Tana 56 Nandi Forest-Trees festooned with Beard-Moss . • 60 my House in Camp on the Guaso Nyiro . • • . 64 A Three Weeks' Shoot on the Guaso Nyiro • • . 64 A Wandorobo Village on the Guaso Nyiro • • . 66 My Wandorobo Hunters . • . . . . . . . 66 IN the Gorghs of the Great Rift Valley . . . . 68 Camp Lanjoro Dis . . . . . . . . . . 68 RHINOCEROS . . . . . . . . . 78 A RHINo looking NASTY JUST BEFORE CHARgING • • . 78 A Good Head . . . . . . . . . . 80 An abnormal Head. The Back Horn is longer than THE FRONT ONB . . . . . . . . . 80 "Hurry up! We Want to eat" • . . . . . 86 Rhino Ground with Kilimanjaro in the Distance • • 88 A Favouritb Hippo Pool on the Tana River • . . 88 A Fine Old Black-maned Lion . . . . . . . 94 


\section{Big Game Shooting}

The Greater Kudu in East Africa

TO FACE PAGE

Greater Kudu in Somaliland

- 100

Greater Kudu Country near Lake Baringo • • . 102

Lesser Kudu . . . . . . . . . . 104

Lesser Kudu . • • • • . . . . . . 104

The ORYX BeISA . . . . . . . . . . 106

Oryx Beisa. Showing the eye stripe and the absence OF HAIR ON THE EARS . . . . . . . . . 106

The Fringe-eared ORYX . . . . . . . . . 108

FRINGE-EARED ORYX . . . . . . . . . . 108

FRINGE-EARED ORYX . . . . . . . . . . IIO

A Baby Oryx Callotis . . . . . . . . . 110

Buffalo . . . . . . . . . . . . III

"AlONE I DID IT!" • . . . . . . . . . II2

The Entrance to The Swamp . . . . . . II6

One of the Perches we built for the Buffalo Drive a il 8

Into the SWAMp AfTer a Wounded Buffalo • . . I 20

A Fine Old Bull Buffalo . . . . . . . 122

The ENd of the Buffalo Hunt • . . . . . 122

TAUROTRAgUS LIVINGSTONI

A Bull Eland . . . . . . . . . . . 126

A Cow Eland . . . . . . . . . . 126

A Roan Bull . . . . . . . . . . . 128

"MASTER" With a ROAN Head . . . . . . 128

AN IMPalah Buck • . . . . . . . . 132

A Water-Buck on Lake Naivasha . . . . 132

A Sing-Sing Waterbuck • • • • • • • . 134

A Small Ellipsiprymus . . . . . . . 136

Cobus Ellipsiprymus . . . . . . . . . 136

A Bull Wildebeest . . . . . . . . . 140

A "Safari" on the Athi Plains . . . . . . 140 


\section{Illustrations}

COKE's HARTEBEEST

TO FACE PAGE

NeumanN's Hartebeest . . . . . . . . 142

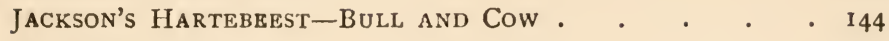

BURCHELl's ZEBRA . . . . . . . . . 148

"Tommy," the Tame Zebra, at Naivasha . . . . 148

A Bush-Buck . . . . . . . . . . ${ }^{152}$

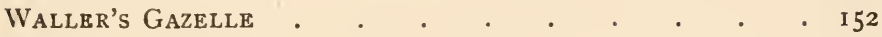

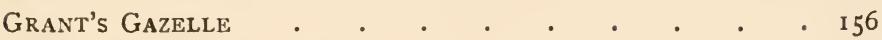

A Female Grant's Gazelle • . . . . . . 156

Some Heads of Gazella Granti-Robertsi . • • . 158

The same as above at a different angle . . . . 158

Thomson's Gazelle . . . . . . . • . 162

BOHOR REED-BUCK . . . . . . . . . 164

A Cock Ostrich in Full Plumage . . . . . 168

A Hen Ostrich • . . . . . . . . . . . 168

A Typical Camp under Kilimanjaro • . • . . 172

Kibawenzi, the Lesser Peak of Kilimanjaro, at Midday. i72

Kilimanjaro before Sunset • • • . • • . . 176

Kilimanjaro at Midnight • • • . • . . 176

The Swing Bridge at Thika-Thika River . . . . is 8

The Crossing of the Maragua River . . . . . 190

Soba Station in the Nand Hills • . • . . 196

Masai Spearmen, showing the different Costumes (sic) • $20+$

A Masai War Dance . . . . . . . . . 204 



\section{BIG GAME SHOOTING ON THE EQUATOR}





\section{BIG GAME SHOOTING ON THE EQUATOR}

\section{INTRODUCTORY CHAPTER}

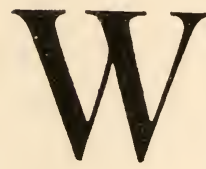

HILST I think of it, I may here state a very bald fact: that one stalks game; every one knows it, and that it is the proper thing to do; but I wish to say that no matter how rare the beast may be, and how awfully anxious one may be to get it, or if, on the other hand, it is very common, but one wants meat for the pot, it is absolutely playing the game to make the most careful stalk possible. It is playing the game to oneself, as it teaches one experience, and also to the animal, as it makes all the difference to him whether he is killed outright or goes off and dies a lingering death in the jungle, probably being helped to shuffle off this mortal coil by hyenas, and therefore being no meat or trophy for any one. One must take one's chance at an ostrich "at 600 yards running," as my Masai orderly used to say. 


\section{Big Game Shooting}

It was part of his job to tell me his idea of the sighting, for his education. But when one comes across any other kind of animal, it is not playing the game to open "magazine independent" at 300 yards or 400 yards. I remember in April, I904, when coming down by train and passing Elementeita station, I heard a fearful fusillade going on, and on asking the station-master there he said a party of four "bwanas" were shootingand I should just about think they were! I am sure one of them must have had a 600 cordite. Never again to Lake Elementeita!

Personally, when on the march, I know for a fact that I am little or no use after a six hours' trek, if I have had no food on starting, so I put off shooting till I have had my breakfast. Whilst one is on the subject of stalking, it may be mentioned that a practice that is most interesting is when one sees an animal one does not want, to walk up as close as possible, and see what liberties one can take with him; walking in a bee line, walking across him, etc.

I hope that the old and experienced big-game hunter will not unduly deride these strange remarks because he knows the whole show, and because it may also be the usual way of carrying on; but really one does not like to see young fellows come out having spent such enormous sums on batteries, outfit, etc., and after all that, make such fearful and awful mistakes, simply 


\section{Introductory Chapter}

because they really and honestly didn't know, that I hope this may give a helping hand to a few.

To return to the point!

Anything, as a hard and fast rule, at over 300 yards should be avoided-200 yards is too far; except on an absolutely flat plain, when one cannot even "worm" up to one's object, one should never fire at over 100 yards or 150 yards. With a very small amount of patience 80 or even 60 yards can often be reached, but it sometimes makes one sweat a bit, as, besides the exertion, all one's nerves are concentrated on not being seen, heard, or winded-I usually end up wringing wet after taking on a really stiff stalk.

I think it is a most necessary thing that directly one sees an animal, distinctly that is to say, one should have one's mind made up-"I want that!" and go for him at once without the slightest hesitation, telling one's men to walk straight on, also without delaying at all. It is almost a hard and fast rule that directly an animal sees the row of people walking in single file stop or hesitate, he is off like a bird. If you want the animal, go straight at him. The chances are that he will watch the number of men and porters walking along, and not you by yourself. Take the following as an example in point. They say that birds cannot count, so why should animals? I remember reading in a book as a boy, an account of how some one wanted to kill 


\section{Big Game Shooting}

a kite, but that whenever the man approached the nest, that kite got out of the way! I tried the same myself on a kestrel that annoyed the poultryyard "some," with the same result. However, on taking a small number of village boys with me and making them walk straight on whilst I stopped, I managed to secure the arch-villain on his or her return almost as soon as the other boys were well away.

On no account, when you see any animal, even one that you want very badly indeed, run! You are bound to do one of two things-first, make a noise and so give the show away; secondly, get so out of breath that you can't hold your rifle at all steady. It's often, very often done and is a horrid error. Think of the wind, and go quite easily and steadily at him. It will save you many a swear-word said in earnest.

It is always to be remembered that if one is stalking an animal and it suddenly looks up, and one makes almost certain that one is seen, the animal in question may often be badly bluffed by one's remaining absolutely motionless, not moving head, hand, or foot; standing if necessary with one foot in the air in the act of walking. The chances are that after one or sometimes two minutes, the beast will continue feeding, as he thinks you are only a tree stump! I recently met a zebra and took him in badly by waiting sitting down with all my gun-bearers for ten 


\section{Introductory Chapter}

minutes. He was head on and had seen us, but I wanted a heart shot and eventually got it. No one moved.

The smallest clump of grass will enable you to drop down and then take out your glasses and decide if his head is worth having or not. On very, very few occasions is it safe for every one to stop and begin pointing. I hate a shikari who points! Let him get you behind the nearest bush and then he can do what he likes-it takes a lot of teaching though! As a general rule the animal stands and watches one for a bit. If he makes off he will more often than not stand again twenty or thirty yards farther on, so one should be always ready for that shot.

Staying motionless is to my mind most important; also, when stalking any animal, carry your rifle either at the "trail," but with the muzzle pointing upwards, or at the "present." The latter is preferable. If one has the muzzle pointing downwards the sunlight is bound to flash off the best browned rifle in the world. I have now a Mannlicher with the top of the barrel left roughened, but even then the smooth oily parts of the bolt give the show away if I carry it with the barrel pointing downwards. In certain cases of game going suddenly off with a rush, I am sure it must have been the flash from the bright parts of the rifle, as there was at the time nothing else to account for it. 


\section{Big Game Shooting}

I suppose every one knows that, on being hit in the heart, an animal goes off with a rush for fifty yards before falling dead; hit in the lungs, he will not go very far, and a bloody froth comes out of his mouth and nose; whilst a shot in the neck floors him on the spot, but does not necessarily kill him. One knows when one is shooting straight, in which case go for the neck. It settles the matter at once.

I am very much afraid I shall be thought to be peculiar about stalking when I say that I have an absolute mania about being by myself, and not having a gun-bearer within two hundred solid yards, if that. I am not talking about the actual pursuit of dangerous game, when one wants a second gun at one's finger tips, but of ordinary common or garden game. Given that one has taken proper care (one should know that for certain), and that the wind is all right, if that animal goes off with a rush, turn round at once, and six to four you find it's the beastly gun-bearer who is doing something foolish. He either is saying, "Shoot! Shoot!" in his particular lingo in a stentorian whisper, or else says that he wanted "to see Master kill his animal," and so has shown himself. That is as good as telling you he has got bored. It is part of his job to be thoroughly bored! He has to wander round behind Master all day and every day carrying a very heavy double cordite. He may be sent into camp to fetch porters to 


\section{Introductory Chapter}

carry in dead meat, come back with them, and return to camp. He might be sent off on a hundred and one errands. It is all his job! He knows it! So he is made to be bored. In the same way, when you take out porters to bring in the meat that one hopes to kill, make them follow 400 yards or 500 yards behind. If, on the other hand, I am by myself, as I say, with a small-bore, and a rhino or a lion appears on the scene, it makes one think! I remember hoisting the white flag very badly on one occasion when a rhino arrived. I fled, and just met my gun-bearer half-way, he having taken it all in and run like a hare towards me in time. That is my own look-out; but I may say I have never been wandering round without a "solid" since-just in case! In the pursuit of dangerous game, when one "goes out for to meet them," one's gun-bearer is, or ought to be, so close behind that one can touch him. That is another occasion on which he is likely to be bored!

About my gun-bearers. In India I had a Mohammedan from the Punjab-a thoroughly bad lot, but plucky to the backbone; a hill man for work in the hills, from the district I was shooting in ; and a pet Bheel for anywhere in the Central Provinces. In Somaliland I had a first-rate Somali; but Somalis are proverbially plucky with game, and good at all dangerous game. To show the pluck of the ordinary savage, on one occasion 


\section{Big Game Shooting}

there I sent out with a certain distinguished V.C. officer, for a lion shoot, two men from my company as orderlies, armed with Martini-Enfield carbines and the service sword-bayonet. The officer was badly mauled by a lion, and at once both men rushed in with fixed bayonets, one getting the lion in the chest, whilst the other man stuck him down behind the shoulder-blade. Result, no more lion! Somalis are, as I said, undeniably plucky with any game, and I can give another instance later of a Somali's pluck in this country with buffalo.

Whilst I have been in East Africa I have had two Masai gun-bearers. Both are very plucky. The chief man is very calm and quiet, but, at the same time, quite all there; and the other is as plucky, but makes use of fearful language, so I am told, luckily in his own unknown tongue, on anything exciting happening. Every one to his own taste; but the Somali does want, and can command, an absolutely fancy wage. There are, of course, gun-bearers of other nationalities, and far be it from me to say anything against any of them, but I don't know them, and this is only my small experience.

A few remarks as to skins, etc., may be of some use.

Always keep the mask of any animal you may shoot. A skull when set up on the wall, properly cleaned, looks very well, but put a head skin on 


\section{Introductory Chapter}

it, and see what a tremendous difference it makes. Dress an animal's head in its skin, as nature made it, and then look round at all of them and note how very much more interesting it is to see the different colours and shapes; whether the skin is smooth or shaggy, for instance; while if an animal has a mane, like the Roan, there it is. It makes fifty per cent of difference, for instance, to the Hartebeest. The bare skull of the latter, with its absurdly long face, high horn-pedicle and horns, making the head still more elongated, is just saved by the ears sticking out on each side. When about to skin any head, think for a moment that one looks at it, set up high on the walls of one's ancestral hall, from below. Therefore, so as not to show stitches, or an irregularly cut line, the skin must be cut above, on the top of the neck. If the animal has a mane, cut the neck just on one side, taking care not to divide the mane. The animal will have its throat cut, but be careful to have the operation done not actually in its gullet, as ninety-nine out of a hundred savages will try to do, but at the very base, at the junction of the neck to the body. Cut off the head, and take the whole thing back to camp, "all standing." Arrived there, cut along the top of the neck to the top of the poll. From this point cut two lines, making a $\mathrm{V}$ to each horn. Then skin downwards, finishing off with the lips. The reason of the $\mathrm{V}$-shaped cut, starting with the 


\section{Big Game Shooting}

base of the $\mathrm{V}$ well back, is that by no chance can these cuts be seen when the head is on the wall, as they are well concealed by the horns. Take great care on meeting the eyes or eye-glands, Take all the flesh out of the lips, and, lastly, skin the ears by cutting out all the flesh, and then pushing a table-spoon up between the inside and outside skins. If insects are going to try and damage a skin, they start at any place where skin touches skin, ears and lips. Paint both of these with arsenical soap. Lastly, turn the skin inside out, stuff it well with dry grass, put it in the sun to dry, and after an hour or so rub in dry wood-ashes. It does not matter much about the skin shrinking, as whoever mounts the head for you at home has to moisten the skin, and so can stretch it. When the skins are properly dry, put them in the sun every day, and keep them inside out. The horns of certain animals cannot be taken off. Pull off all that you can. They will not come off for ten days or a fortnight, and you must on no account force them off by hitting them. A lot can be done towards killing maggots in a head, in the jungle, with boiling water. In the rains it is exceedingly hard to do anything with skins, as, there being no sun, they seem to try their best to go rotten at once, if not sooner! Drying by the camp fire is little good, except for a skin that one wants to keep at all hazards. In that case the sentry must 


\section{Introductory Chapter}

watch it all night and keep turning it. It is always one's luck to shoot a rare animal in the rains, and to have to throw away the mask because it refuses to dry properly. As regards measuring horns-in most animals the method is apparent. Take the front curve, start at the base, and measure along, gripping the measure lightly with one's fist, not pressing it into any corrugations, and follow the horn carefully to its tip. In the case of a kudu, start on the ridge at the base in front, and follow that ridge spirally round the horns. An eland is measured in a straight line. A buffalo, at its greatest outside span at the widest part and greatest inside span as well. (This will be usually in the same straight line as the former.) Wildebeest is done the same as a buffalo. Measure a lion, leopard, etc., lying at full length on the ground, sticking a spear into the ground at its nose and at the tip of its tail. Take the animal away and you have the measurement.

The big rains start in the last week in March or beginning of April, and last to the end of May. The autumn rains begin in the middle of November and go on for a month or six weeks. If you shoot in the rains, or directly after, you must take most of your shots standing, and you will be thoroughly badly wetted by the long grass in the mornings. A month after the rains the grass dries up by reason of the heat of the 


\section{Big Game Shooting}

sun, and is then burnt by the natives in most places. That is your time! Make arrangements accordingly, and be first on the ground.

I am afraid I have not mentioned smaller game in this "effort," such as duiker, steinbock, oribi, dikdik, etc., as I have been thinking more of the big heads to adorn one's baronial halls with-but shoot them! Their heads are worth having, and they are good eating, added to which, that is the class of animal amongst which one always stands a chance of finding a new species, because, there being at present such heaps of different varieties, there is no reason why Tom, Dick, or Harry should not find a new kind somewhere, and have the honour of it being named after him. Harryi would sound quite good! Again, in the bird line, greater bustard, lesser bustard, florican, guinea fowl, francolin, four different kinds of partridge, sand-grouse, and quail in thousands, to say nothing of duck, teal, and snipe, are to be had in great numbers, each in their different locality, and one does appreciate them, after the never-ending assortment of " nyama," cooked in various ways, and day after day. No. 4 shot ought to see one through, with a few No. 6 thrown in, and say fifty No. 8 for the quail and snipe.

Any attempt at advice on rifles I shall leave alone. Every one has his own pet ideas on that subject. I have found a double hammerless ejector, $400-450$ cordite, by Cogswell and 


\section{Introductory Chapter}

Harrison, a Jeffries 256 sporting Mannlicher, and a double I 2 -bore hammerless ejector, also by Cogswell and Harrison, quite sufficient for my wants in this country. They have done me extremely well.

As regards clothes, the same applies. I wear ordinary khaki. If a man wants a coat, flannel shirt, or cholera-belt - well, he knows it, and there is an end of that! At the same time I see little use in any one spending $£$ IO or $£ 15$ in the latest kinds of shooting coats, etc., with possibly patent elastic pleats, or some such tomfoolery, when any kind of shake-me-down does in camp. We all come to rags and patches in the long run.

A last word!

(I) Don't ignore a good gun-bearer's good advice because you think you know a thing or two.

(2) Don't slang him, or any one else, because you have a liver in the morning.

(3) Don't beat every one on the slightest provocation.

(4) Don't let a native start thinking for himself. Give him every possible direction, even down to the slightest detail.

(5) Don't promise a native a thing you can't do.

(6) Don't allow him to play with your guns.

(7) Don't worry any one when you may just as well leave it alone.

(8) Don't see your kit packed up. Something is bound to be upset. Hence-loss of temper. 


\section{Big Game Shooting}

(9) Don't on any account lose your temper and shout. (N.B.-This is very difficult!)

(Io) Don't cut the men's ordinary rations for a misdemeanour. They have got to live.

(II) Don't be taken in by any dodge they may try on. They will know you in a week, and it will then stop.

On the other hand-

(I) Remember a savage was born a savage and brought up a savage, and always will be one. $\mathrm{He}$ has no brains. Treat him accordingly.

(2) Decent servants will make you quite comfortable in camp after a week, when they know your ways.

(3) With a good headman, leave your caravan to him. He knows his job, and fussing will do harm.

(4) Feed your caravan with meat when you reasonably can, extra to their rations.

(5) It is very little use cutting the porters their pay when on trek, as it is a punishment for the future, and they do not feel it at the moment when it is all-important.

(6) You will have a real good time if you treat your dependants quietly and justly. It is they who make your time pleasant or the reverse, almost more so than good shooting.

I have used the word "local" in the following pages when describing the different kinds of 


\section{Introductory Chapter}

game that are to be met in the country, in the following sense :-

They may be roughly found in the same place every day at a certain time of the day. That is to say, in the morning they are feeding in a certain place, in the afternoon at another, and in the evening it is almost sure that they will be in a third place. If one can find out where these places are, one may be saved trouble, by not disturbing the herd if one does not want that particular kind of head; and getting a herd on the run means that it gives notice to the surrounding jungle, to a certain extent, that some one is about.

\section{PORTERS}

A few words on porters will, I hope, not come amiss.

Wanyamwezi and the real old Swahili are paid ten rupees a month and "posho" (rations); Wakamba, five rupees a month and "posho"; Wakikuyu, four rupees and "posho." The last named do not like going very far from their own country, and will not go to a waterless country; and if they are not dismissed in two months or so, in order that they may get home, they will possibly bolt and leave the shooting-party badly hung up.

Wakamba do not mind where they go, but as they live east of Nairobi, they are hardly 


\section{Big Game Shooting}

ever used north or west. They are first-rate trackers.

Both the last two mentioned are really good porters, will carry any load, and come into camp all together. Both are savages and speak "no known tongue," so they must have their own headman, whom, if he is not accredited by an official, they will choose for themselves.

In the old days the Wanyamwezi and Swahili were the only porters used anywhere; splendid porters they were, but they seem to be rather dying out now, besides which the bulk are nowadays only obtained from Mombasa, and in that case, the railway fare up to Nairobi or any other station makes them rather prohibitive. I must add, however, that it is by no means a very easy matter to get Kikuyu porters at Nairobi at certain times of the year.

All porters must be provided with a blanket and a water-bottle. They will produce their own thongs for tying up loads, but it is a sound thing to take a certain amount of rope with one.

Bring out from home twenty or thirty knives with a wooden handle, broad blades, fifteen inches long, and made of soft iron. The local savage thoroughly understands this weapon, as all his own cutting tools are made of the same material, and he can sharpen them with ease. This is rather important.

Prismatic field-glasses or a telescope are left to 


\section{Introductory Chapter}

the sportsman's taste, but note that glasses take up less room in one's pocket.

Go to John Edgington for your tent, and get a green rot-proof one of about $120 \mathrm{lb}$. It is two porters' loads, and is quite big enough. One's personal dependants want a tent, but that can be picked up second-hand in the country, as also can porters' tents.

Six to ten porters go to one tent.

A porter's load is $60 \mathrm{lb}$., which ought to include their "posho" for two or three days.

"Posho" is one "kibaba" of rice; or

one do. beans; or
one do. matama flour; or
half and half of two, per diem.

A "kibaba" is a tin pot measuring about one and a half pounds.

Any meat you shoot for them, except on emergency, when it should invariably be explained beforehand, is extra.

When one kills an animal the meat is always brought to one's tent door, every bit of it, and divided up by the headman. That ought to be a fixed rule, and they all know it.

It saves bother to give out "posho" for three or four days at a time. Take no excuse if it is all eaten in one or two days. Let them starve, that is all.

Twenty miles is a pretty good march for porters, but one will not want to do this unless one is 


\section{Big Game Shooting}

making for a point from which to start operations.

For one's personal entourage and safaris one needs-

One headman.

One head gun-bearer.

One second do.

One cook.

One cook's boy (whom he will pick out from amongst the porters).

One personal boy.

One small boy.

Twenty porters for kit, tents, cooking-pots, rifles, personal food, etc., will be found ample.

When one goes from one town to another, or food district to another, matters are quite easy, and from five to ten extra porters will be sufficient to carry their own food. This is almost always the case, as the headman takes the porters away and arranges to meet one at some distant point, say a week later, and porters can always carry a small amount of their own rations.

A licence costs the sportsman $£ 50$, and the amount of game allowed on it is liberal. I must say I should very much like to see one or two more animals put on the list of animals not to be shot, and one taken off. An appendix shows the numbers of animals one has to pay extra for, and their prices.

A list of impedimenta that are absolutely 


\section{Introductory Chapter}

necessary for a shooting trip may be of use to a tenderfoot.

(a) To be brought from England:

A green rot-proof tent, double fly, with bathroom.

A "Paragon" folding-bed.

A cork mattress and bedding.

A "Paragon" table, three feet square.

A do. chair.

A "Roorkee" chair.

A "Paragon" wash-hand-stand and bath in one.

A "Lord's" lamp complete.

All ammunition should be sent out beforehand consigned to Messrs. Smith Mackenzie, Mombasa, who would act as one's agents in the country.

There is no difficulty in landing it. The P. \& O. will not carry explosives.

A case of aluminium cooking pots.

(b) Can be obtained in the country :-

Mosquito curtains are indispensable, and can be made much cheaper than in England.

All food, drink, stores, etc., can be obtained on the spot, but it is cheaper to have them sent out from home.

"Chop boxes" for packing stores into 6o-lb. loads can be obtained without difficulty.

Messrs. Smith Mackenzie of Mombasa might be able to secure a good cook, but it would be 


\section{Big Game Shooting}

advisable to write and ask them beforehand to obtain a "boy" (personal servant), shikari, and all the rest of them, at Nairobi.

The best route to go to British East Africa is by the monthly Austrian Lloyd steamer from Trieste straight to Mombasa.

The German East African and Messageries Maritimes liners also go to Mombasa without a change on the journey.

The approximate cost of the return journey by sea to Mombasa, return railway fare to Nairobi, allowing for stewards' tips, wine bill on the ship, etc., should be covered by $£ 80$.

The remaining expenses when actually in the jungle shooting would decrease naturally in ratio if two, or even three, men went out to shoot together in the same shooting party.

Presents of sheep here and there, which would cost say four or five rupees apiece, would be ample. There is no necessity to take large stocks of beads or wire, except in the most outlandish parts.

If it is intended to ride when on the march from one point to another, a mule, which can be bought for 250 to 400 rupees, will be found the most suitable for the purpose, because grain, which would be indispensable for ponies, may be unobtainable in certain districts.

If it is intended to make a long expedition right away from civilization, donkeys would be 


\section{Introductory Chapter}

most suitable as transport. These can be bought mostly for thirty or forty rupees apiece at Nairobi ; but it would be advisable to write to one's agents beforehand, as slight difficulty might be experienced in procuring them at a moment's notice. Donkeys will carry a load of $\mathrm{I} 20 \mathrm{lb}$. each; they want no extra food beyond good grazing, and one boy could easily look after five or eight. Some fifteen or twenty porters will be found necessary as well, to help carry loads over bad places, to keep watch at nights, and for a hundred and one odd jobs.

All the officials and residents in the country will be found most obliging, and only too glad to help with their advice or in any way to further the requirements of the sportsman. 


\section{IN UNTRODDEN PATHS}

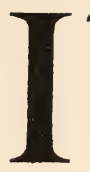

$T$ is my intention in this chapter to set forth a few experiences in the untrodden wilds of Eastern Equatorial Africa, which may be aptly called the "Sportsman's Paradise." Mombasa not so long ago was one of the big centres of the slave trade, and one can well imagine how suitable its innumerable creeks and rivers, running inland in all directions, were to the lawless operations of the raiders who navigated the swift-sailing dhows which carried the hapless slaves.

Mombasa also forms one terminus of the Uganda Railway, which stretches six hundred miles inland to Lake Victoria Nyanza, the greatest of the African lakes. What used in former days to be a dead-and-alive town is now transformed into a busy hive of industry, with the daily arrival and departure of trains instead of the very occasional return of a caravan of porters from the interior. The platform is thronged with savages-all clothed, however, as enforced by law-and as much in their right minds as an African savage 


\section{In Untrodden Paths}

can ever hope to be. Some have come to greet -iends, others have been sent with weird-looking trrows to take away merchandise; but the reater part are there just to help things by ooking on with staring eyes and capacious mouths agape.

One fine day, duty on firearms and other odds and ends having been paid, hotel bills settled, and baksheesh duly doled out, I took the train en route for Nairobi, three hundred and twenty-five miles away. Everything was in the van, I was led to believe, and I said good-bye and settled myself to the monotony of a journey in a very comfortable carriage, built on the Indian pattern, with two seats which become beds by night; two other beds, at present folded up along the ceiling and the wall; and every convenience for the modern traveller in the East.

Through groves of feathery palms and banana plantations we sped, pulling up at a wayside station every ten or fifteen miles. Looking out upon the scene, one saw the inevitable Indian station-master and his two or three dogs in the foreground, and in the distance rolling grass or dense bush. So we progressed till we reached the Taru Desert, with its beautiful, bright-green thorn bushes and red sand-sand that rises into the air with the draught created by the train and enters the carriage at every crevice. On waking next morning somewhere near Simba Station, I 


\section{Big Game Shooting}

found my eyes and ears full of sand, and everything was brick-red and grimy.

We were now approaching the vast rolling Kapiti and Athi plains, thronged on every side with innumerable herds of antelope. These herds of game may be counted, not by ones and twos, but literally in hundreds, and that from the windows of a railway carriage, so that the thought at once strikes the sportsman: "If I can see this close at hand, what must there be in the little-known districts miles away ?" Zebra, hartebeest, and gazelles swarm around, with a few wildebeest, and, if one is lucky, a rhinoceros may be discerned in the background.

So this wonderful panorama continues until Nairobi is reached, where one unpacks oneself and belongings and repairs to the hotel till arrangements can be made for continuing the journey.

This hill-station, five thousand odd feet above the sea, with its back to the Kikuyu forests and the Athi plains at its feet, is a thriving town, built for the most part of corrugated iron, and is the hub of the local universe. Warm in the English winter, with frosts at night in July, it occupies the proud position of being probably the only health resort on the Equator. With its pack of hounds, its club, with tennis and cricket grounds, its race weeks and attendant dances, and the extreme hospitality of all and sundry, Nairobi 


\section{In Untrodden Paths}

is a wonderful place indeed. On a clear morning in January the view is magnificent. With the town at your feet you look due north and see the snow-clad peak of Kenia, a hundred miles away, outlined against a vivid blue sky, whilst almost due south the twin tops of the highest mountain in Africa-Kilimanjaro-loom over the horizon at an even greater distance.

The forest land round Nairobi is very beautiful. Roads have been cut through it everywhere to enable the colonists to send their produce into the town in carts, instead of using the old-fashioned method of employing porters, who are expensive, besides being only able to carry a weight of sixty pounds on their heads.

On one occasion while in this region I had command of a column which consisted of two companies of the King's African Rifles. Our object was to worry some outlying tribes under Mount Kenia who had been annoying our friendlies in that direction, and had finally taken upon themselves the wiping out of a small native trading caravan. I had with me some Masai spearmen who were supposed to act as guides, counsellors, and friends, and to make themselves generally useful. And right good fellows they proved to be, in spite of their war-paint and evilsmelling feather and skin decorations.

The Masai were the old fighting race and hereditary rulers of this part of Africa, terrorizing 


\section{Big Game Shooting}

their neighbours and looting indiscriminately. No one knows whence they came, but their fairytales and folk-lore bring back the works of Grimm and the days of one's childhood in startling fashion. There are two extraordinary things on the East Coast of Africa. One is the Great Rift Valley, an example of volcanic action stretching roughly from the Sea of Galilee in Palestine, taking in the Great Lakes, and reaching to Quilimane and the mouth of the Zambesi. The other is the three curious tribes dwelling at intervals along it, starting, roughly again, with the Somali, continuing to the Masai, and ending with the Zulus. Little or nothing is known about any of these races except that their characteristics are peculiarly alike. All are more or less nomadic in their habits, all are cattle fanciers, and there is a lot of fight in all three of them.

The Masai are divided into several sub-tribes, each of which has its particular device painted on the oval skin shields, added to which are small lines or spots indicating the various families in that subdivision. The colouring is white and red with a very little black. They carry a nasty-looking spear, each end of which is made of soft iron, the "business end" being a blade some thirty inches long, and the butt an iron rod, used chiefly to stick the spear upright in the ground.

The men wear head-dresses of assorted shapes and sizes. The courageous warrior may be 


\section{In Untrodden Paths}

known by his tawny, cone-shaped hat of lion-skin, denoting that he has killed the animal himself; the usual run of fighting-man, however, is decked out in an oval ring of ostrich feathers which he wears over his head, kept in place behind with a thong of leather; the feathers are black, with two or three fine white ones at the highest part to give additional height to the wearer. Others wear tippets of "whydah-birds'" feathers, thick and very warm, which exude a certain effluvium. The rank and file make their appearance in nothing, and hope for the best! The warriors also carry one other weapon, a sword, called locally a "simi," which, though of soft iron, cuts to some purpose.

The Masai, as I mentioned before, are splendid fighters, and are enlisted as soldiers in the King's African Rifles, one company of which is composed exclusively of them; and first-rate soldiers they have proved themselves. They are very nice, easy-going fellows, who give no trouble, work hard, and don't drink-in fact, they are the best savages I have ever met.

The place we had to make for to commence our patrol was Fort Hall, the chief station in the Kenia province, and thither we bent our steps, travelling, for the first forty miles, across the Athi Plains, directly towards Donyo Sabuk, a wellknown mountain landmark in the countryside ound Nairobi. Game abounded on each side of 


\section{Big Game Shooting}

the narrow, well-worn footpath which does duty as a road in the East African wilds; but no adventure worth recording befell us, except that I shot my first water-buck.

Ere long we arrived at the Thika Thika River, which at the point of crossing runs deep down between steep banks in a broad ravine. A wooden, double-lock bridge had been begun, but had been left unfinished, and as the wire hawsers used for hauling the big baulks into position still stretched from side to side, we used these instead. One by one we sat in a rough wooden seat and were pulled across with a rope, the contrivance being hauled back again and again, till all the men and baggage were landed in safety on the right side of the river. No accident happened, luckily, as there was a longish drop to the water, which, moreover, swarmed with voracious crocodiles of the finest type. However, we provided them with no food that day!

Another thirty-five miles saw us at Fort Hall, a large stone fort with a ditch outside, perched on the top of a hill commanding a splendid view of mountain, river, and cultivated plains. The natives in that part-Wakikuyu-are well known as tillers of the soil ; in fact, almost all the labour in East Africa worth talking about is drawn from this huge tribe. After partaking of the hospitality of the genial Sub-Commissioner and his kindly wife, affairs of state were discussed and the 


\section{In Untrodden Paths}

making of history began. A move had to be made to cross the Tana River in two different places, in order to annoy the enemy as much as possible, the two parties effecting a junction again in a week or so.

Arrived at the river-bank, where there is a well-known ford, the first thing was to get a rope stretched across, and attach to this by pulleys a small punt we had brought for the occasion. If the river rose at any moment through the melting of the snows on Mount Kenia or the rainstorms which visit this part of the world fairly frequently, there would have been no means of getting back the cattle and sheep which we fondly imagined we should receive from the enemy, so this was done to prevent accidents. All precautions against a surprise were taken here, as although there was little danger in reality, still it was an important point. Camp was pitched that afternoon close by, and a strong cattle zareba built, with strands of barbed wire wound about to strengthen it.

Some few days later the Tana saw us again, and great was our delight to find that the river had not risen, since we had some cattle and sheep to get across, as we wanted them off our hands. After all was said and done, ferrying the stock over in a flat-bottom punt wanted a bit of doing and would have been solid hard work, to say the least of it; but now everything seemed made smooth, so to speak, the cattle being able to walk 


\section{Big Game Shooting}

across without any trouble. They were grateful to get into the cool water out of the heat after having been driven so many weary miles across a burning, sandy plain, and made no fuss at all. The Masai warriors showed their handiness again by walking across with them and patting the beasts to encourage them, and also supporting the calves under the chin when the water got too deep for them.

We used to go and fish at odd moments to while away the time, and one afternoon, whilst I was dreaming at the end of a bit of string, a heart-rending scream broke the silence, and put an end once for all to my reverie. I rushed off excitedly and found one of my men struggling at the end of his line, slipping slowly down the bank all the while. I roared with laughter, for the fellow's face was ashen and his eyeballs protruding with fright. He told me that when he felt a bit of a pull he thought he had caught a fish, but that the creature was so strong it was impossible to get a sight of what it was, much less to pull it out. Meanwhile a crowd of excited people had collected, all jabbering at once. If it wasn't a crocodile he had hooked, I told the unhappy angler, it must be a barbel, of which the river was full, in which case the fish would soon get tired, and something might be done. Somewhat reassured, he stuck to his line, and soon the water swirled violently; then the yellow scales and 


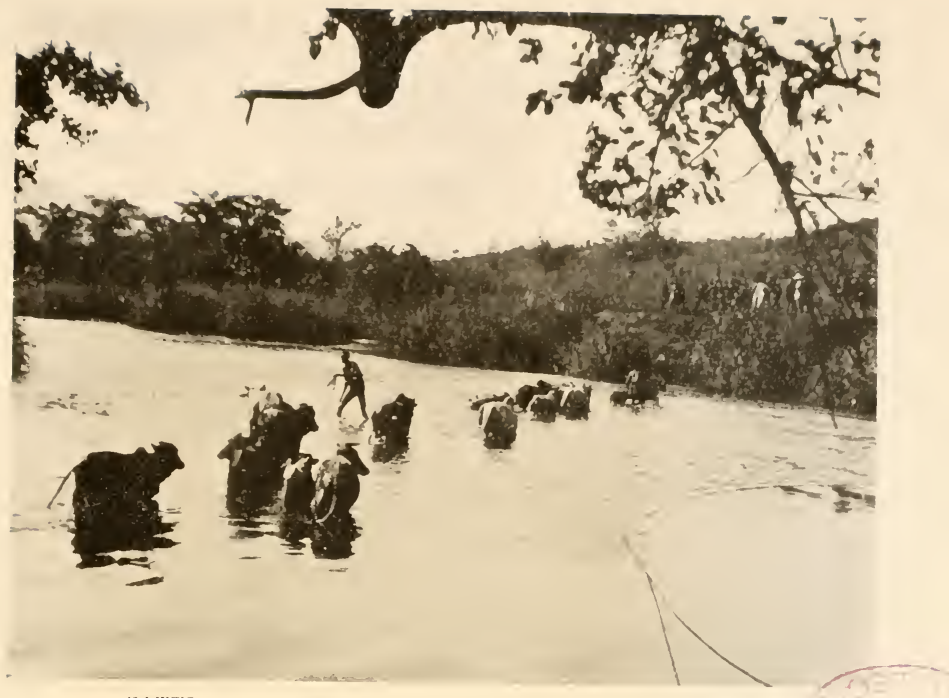

CATTLE CROSSING THE FORD ON THE TANA RITER

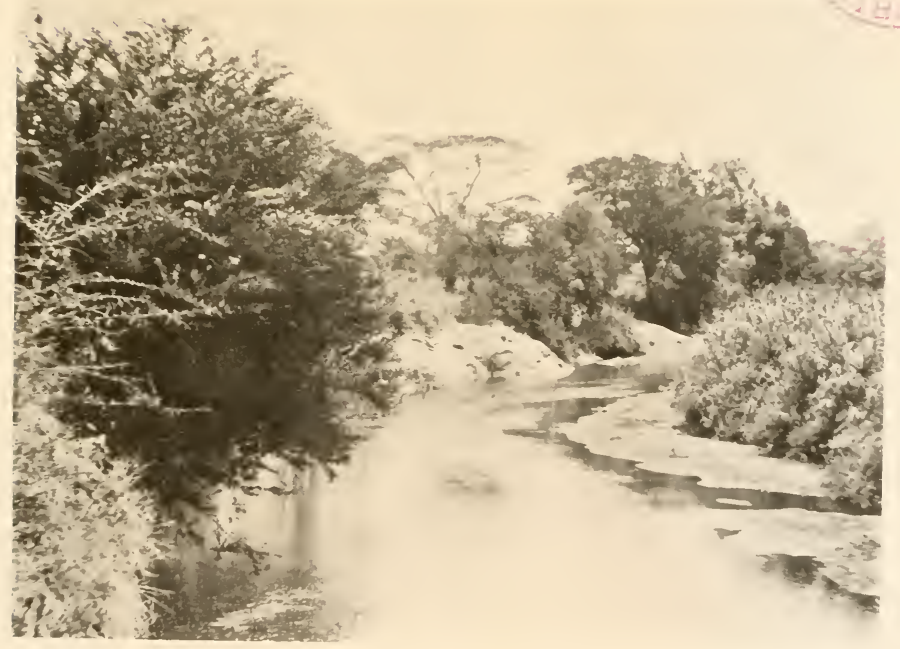

THE THIKA-THIKA RIVER NEAK ITS JUNCTION WITH IHE TANA 



\section{In Untrodden Paths}

huge tail of a monster barbel showed on the surface. One more haul, a lot of shouting and gratuitous advice from the spectators, and two of my gallant fellows rushed in with naked bayonets and transfixed the fish, although how they missed spiking one another I shall never understand.

We had got him, but he was a big thing to fish 'out; however, the spectators soon settled that for us, and placed the monster intact on the bank. Then came the weighing process. That seemed a hard nut to crack, for there was only a solitary five-pound weight available. Some bright person settled the difficulty by suggesting that the barbel should be divided out there and then as food; he was tired of waiting, he said. That gave us a clue. The fish was duly snapshotted, and then cut up and weighed out bit by bit. He came to about forty-six and a half pounds as nearly as I could calculate it, though the last two pieces were rather fragmentary. Their owners, however, didn't object in the least; it was all right, they said, as it was "all fish"!

The cattle in this part of the world are for the most part black and white. They are small as compared with English cattle, and have a hump on the back, much more developed in the cases of the bulls, so that they greatly resemble the mildeyed oxen of India, though their tempers cannot be said to be so equable. We were passing along 


\section{Big Game Shooting}

close to the herd, who, having been rather worried during the last few days, were ready to take offence at anything. They stopped and stared at the white man, and the big mottled bull objecting to being photographed began to stamp and snort, trying to make himself angry. At last he could stand it no longer; down went his head and up went his tail, and he thundered down on the unfortunate camera. Needless to say I skipped over a fence out of his way, and left him master of the situation.

I spent Christmas, 1904, in another part of East Africa. I had gone up by train with my Masai Company of the King's African Rifles, at a moment's notice, to the Nandi country, to patrol the Uganda Railway near Lake Victoria. The Nandi are an offshoot of the Masai, the only difference being that they speak another dialect. They, too, are cattle fanciers, and on the slightest sign of a row away go their beasts-guarded by picked warriors-into the depths of the forests, where they are hidden away in rocky gorges till the trouble is past. One may wander over the hills and along the paths at such times and never see a living thing, but every now and then you hear a shout echoing across the valley from the hill opposite, perhaps a mile away-a shout that is caught up and repeated from one eminence to the other, till the whole countryside reverberates with sound. This is the Nandi method of tele- 


\section{In Untrodden Paths}

graphing from hill-top to hill-top, and by means of it the tribesmen know in a very short space of time exactly what is the strength of the column of troops sent to punish them, its exact locality, and the direction in which it is moving.

They are a crafty people, their favourite method of carrying on warfare being to lie hidden in the thick bush and long grass in ambush for the unwary. When the enemy have approached to within ten or twenty yards a cloud of poisoned arrows is rained upon them, and so sudden is the onslaught that one cannot exactly tell from which direction it comes.

We left the train at Mohoroni Station and marched some six miles up into the hills on the north side of the railway to Soba, a pretty little station perched on a hill-top and in the centre of the section of the Nandi whom we suspected of having caused the trouble.

We set out on our patrol the following day at early dawn, getting soaked to the skin by the dew in the long grass through which the path wound its way, and anon groping our way in the semi-darkness of a primeval forest. Ferns hung down from the banks all round, and long grey strands of beard-moss festooned themselves from tree to tree. Up and down valleys, over the bare hill-sides, in and out of forests we trudged all day, and not a living thing did we see. Then back again we went, the way we had come, arriving at 


\section{Big Game Shooting}

Soba thoroughly tired out and quite ready for bed after a hard day's marching.

We woke next morning with the sun as usual, and found to our surprise that a whole tribe had come in and were sitting down awaiting a powwow, and our pleasure.

These were not the people who had caused the trouble; they said they had come in to talk to us about it, and denounced their brothers as thoroughly bad men, taking good care to make it plain that they themselves were quite good boys. There they were, in the typical attitude of all African natives, gathered together, squatting on the ground in more or less of a heap with their bright spears upright, and their chief-who, by the way, was armed with a formidable umbrellain front.

When everything had been amicably settled there came the inspection of the conventional bullock brought in as a present, which they well know will be duly admired and handed back for them to eat.

When one marches through the wilderness with porters and baggage one usually has some idea of where one wishes to get to-say a hundred miles away-but where to pitch one's different camps on the way is quite another matter. You leave a lot to chance and, with a guide or two who can never be said to be quite reliable, wander along any game path that looks 


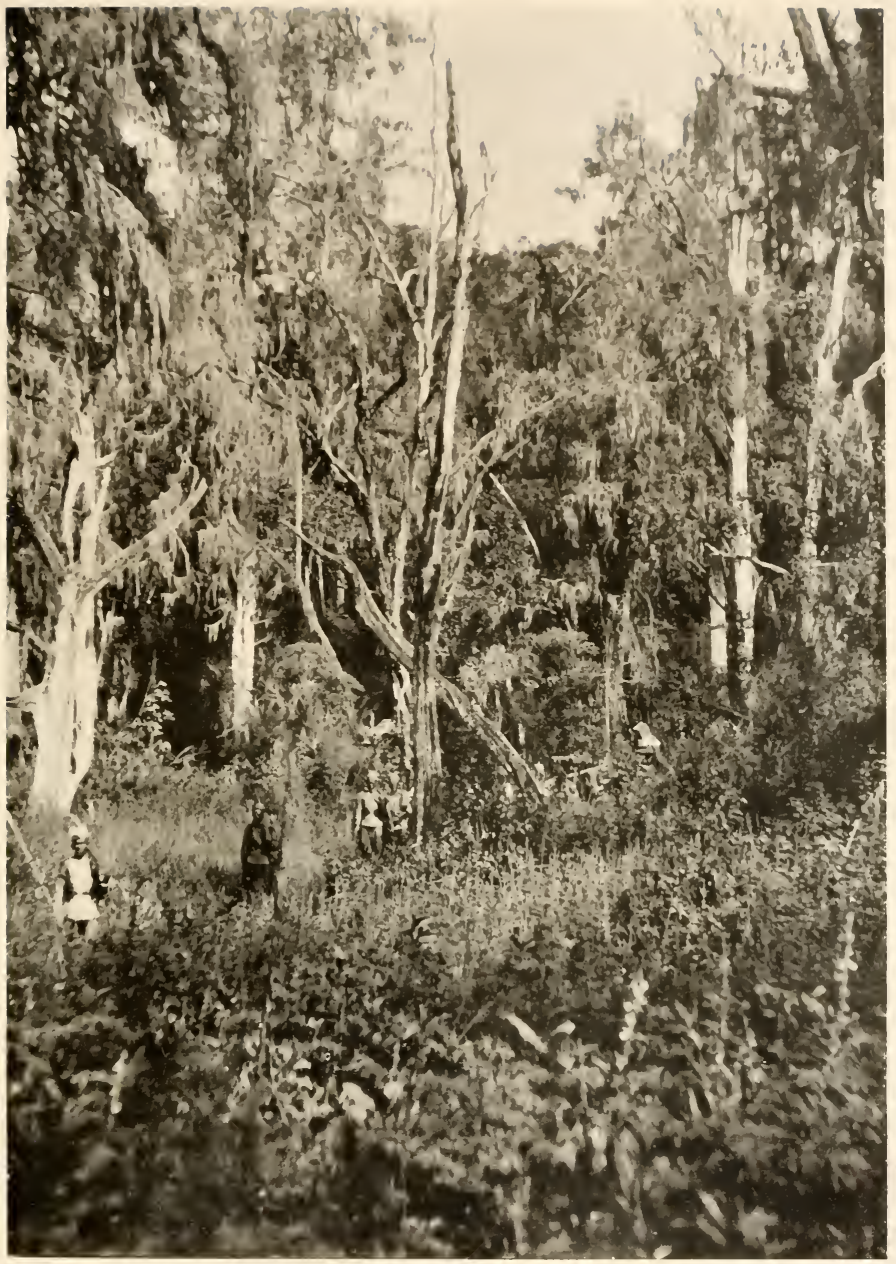

NANII FOREST-IREES FESTOONED WITH BEARI)-MOSS 


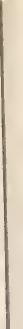




\section{In Untrodden Paths}

as if it led in the right direction. After doing this continually one really gets to think as a native does of time- that it doesn't matter. So if you do go out of the way for two or three miles it is all the same in the long run, and some good shooting may be picked up by the mischance.

On the march first of all comes "master," with a guide who says he knows the locality, and two or three gun-bearers; then, a mile behind, come half the escort of soldiers, close in front of the porters with the baggage. These again are followed by the remainder of the escort, whose business it is to keep the porters closed up and hurry on the laggards. By this formation, if game is met with on the way, you have a decent chance of getting in a shot without the animal being frightened away by the noise and chatter of your men, to say nothing of the strange and dreadful-looking packages they carry on their heads, some of which are enough to frighten any proper-thinking animal out of his senses. A signal from either side of the track, if anything should have been killed, will bring up the whole "safari" (caravan) helter-skelter on the chance of obtaining the much-coveted "nyama" (meat). The tit-bits-the tongue, kidneys, and saddle of an antelope, for instance-are by common consent always kept for "master," so he never worries himself, except to see that all meat is 


\section{Big Game Shooting}

brought along to camp, where he divides it out in the evening.

The only thing worth recording during the hundred and ten miles' march that brought me to the foot of the Laikipia escarpment, on another occasion, was an adventure with a rhinocerosone of those incidents that are always occurring if one wanders about this part of Africa often enough.

We were proceeding in single file through grass up to our knees, threading our way in and out of thorn bushes, when, without the slightest warning, there was a crash and a snort, and the unwieldy bulk of a bull rhinoceros loomed up some ten yards away. He had been lying in the friendly shade of a bush out of the sun, and had only just scented us. There he stood, swaying his head from side to side, apparently not having quite made up his mind what to do. He was in such close proximity to the path that I was afraid of leaving him alone, because he would be almost certain to get more angry and end by doing some considerable damage to property if not to life. So bang went the rifle, and with a thud the bullet hit him. Down came his head; then he grunted once or twice, and charged straight at us! He was thoroughly angry, determined to annihilate us or die in the attempt.

I could not quite understand how it was that I had not killed him on the spot, as he was so close, 


\section{In Untrodden Paths}

but there was no time for speculation. I gave him the other barrel, and luckily he tumbled down a couple of yards away, shot in the neck, and died almost instantaneously. On examining him after he had been cut open, I found that it was really the first bullet that had killed him. An animal shot in the heart, although dead to all intents and purposes, invariably makes a sudden rush in any direction for perhaps fifty yards or so before he falls down. The second shot, therefore, was unnecessary, although, of course, I could not possibly have known that at the time. His horns were nothing to speak of, but the body was all meat. The porters, with loud shouts, at once set upon it to cut it up. The head, feet, tongue, and tail were reserved for me, as usual-rhino-tail soup is excellent-and when a couple of ribs had been hacked away one of my small boys plunged bodily into the cavity, and after groping about for a few minutes appeared again, smothered in blood, jubilantly holding up the kidneys for my inspection; I thanked him and said he might keep them.

On joining the Anglo-German Boundary Commission, I arrived at my destination on my birthday, so it was an occasion of rejoicing for me, the more so because I had finished a lonely march through the wilderness and had reached the abode of my friends. 


\section{Big Game Shooting}

The camp was pitched in an open glade on a bend of the Guaso Nyiro River, which runs into a soda lake some ten miles away in German territory, called Lake Natron. Tents had been discarded long ago, both on account of the heat and also in order that they should not be worn out with unnecessary use. Instead we built ourselves large and airy houses of grass, thatched on a big framework of poles. The houses were some sixteen feet high, topped with a long ridge-pole, and about thirty feet long, thus giving plenty of space for a bedroom and sitting-room in one, and ample accommodation for one's boxes of food, general baggage, and trophies of the chase. The huts were open at both ends, to allow of a free passage of air right through.

My domicile is shown in the accompanying photograph. The grass has been cut all round forming rude paths, and a buffalo head is drying in the sun. One has to sleep under a mosquito curtain. The winged pests appeared regularly at sundown, and kept up their maddening music till next morning. There was no getting away from them.

This was a splendid shooting centre, the country simply swarming with antelopes of various species, buffalo, giraffe, rhinoceros, and partridges. After one has fed on venison for a time a bird is a great relief from the tough steaks and legs, however nicely they may be disguised by a good cook. 


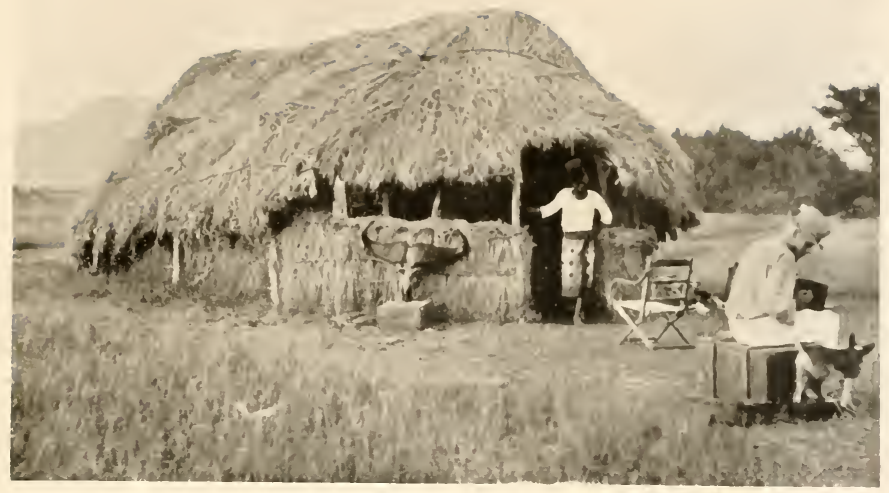

MY HOUSE IN CAMP ON THE GUASO NYIRO

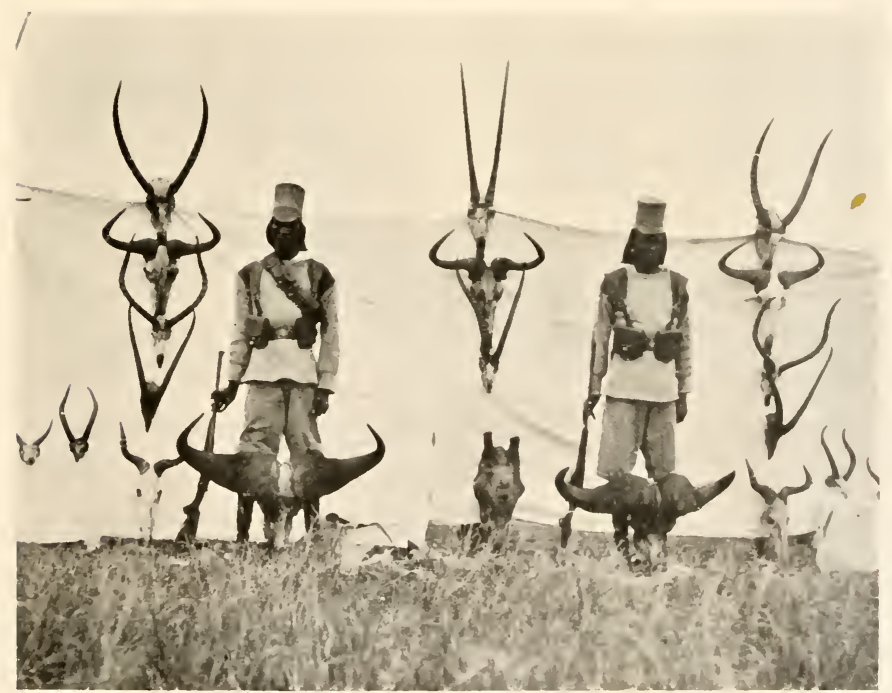

A THREE WEEKS' SHOOT ON 'THE GUASO NYIRO 



\section{In Untrodden Paths}

Wandering about the other side of the river one evening in search of something succulent for the pot, I chanced upon an old village built by the Wandorobo-the hunting tribe of East Africa. They are extremely shy of the white man, and, although never hostile, they seem nervous of having much to do with him. Small settlements of this peculiar race of aborigines may be found in the gloomy depths of almost any large forest in this part of the world.

The village, shown in the accompanying picture, consisted of a big circular zareba of thorn bushes, high and strong enough to prevent a lion from breaking through and stealing any of their stock. Inside the space was divided into different little "corrals," some containing tiny round houses of sticks and leaves, others for sheep, goats, and cattle. This village was peculiar of its kind, as, owing to the mosquitoes being so troublesome, the savage in this district has taken the infinite trouble to build himself houses perched upon long poles or stilts. The mosquito finds its home close to the ground in the grass, so that a house raised fifteen feet or so is almost immune from its attacks.

The Wandorobo, by the way, are the poorest of the poor. If they are met in the forest on the march, their worldly possessions and stock-in-trade are interesting. They seldom wear even the conventional fig-leaf. They are armed with a 


\section{Big Game Shooting}

bow and some twenty arrows, and usually carry a bit of rag carefully tied up, which contains some strips of bark which they use for medicinal purposes, somewhat in the same way as we use quinine. They possess hardly any sheep or cattle, and what they have are very carefully herded and looked after, being their most valuable commodity. In a country where a sheep costs six or seven shillings, they would infinitely prefer a present of two or three sheep to the same number of sovereigns. I was lucky enough to secure two Wandorobo hunters, who accompanied me everywhere, and most useful they were.

They were half starved when I first met them, so their hearts were won at once by the gift of some ribs of a rhinoceros which had just been killed. They said nothing, but took out their knives and devoured the flesh raw on the spot, seizing a bit of meat in their teeth and pulling at it, hacking the while at the bone with their knives. My men went into fits of laughter when they saw the unconscious hunters, too busy with their bones to notice my action, being transferred to the " picture box."

After having enjoyed the shooting round the Guaso Nyiro for the best part of a month, the time came for us to shift our camp some forty miles away over a waterless desert to a range of hills that could be made out in the dim distance, 


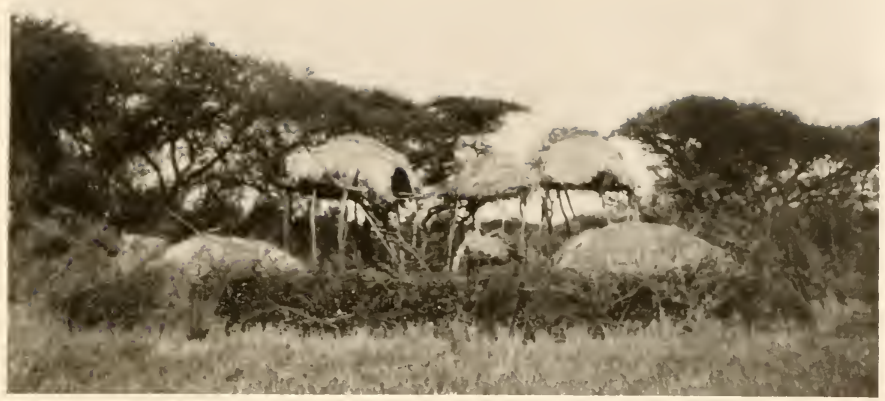

A WANDOROBO VILLAGE ON THE GUASO NYIRO

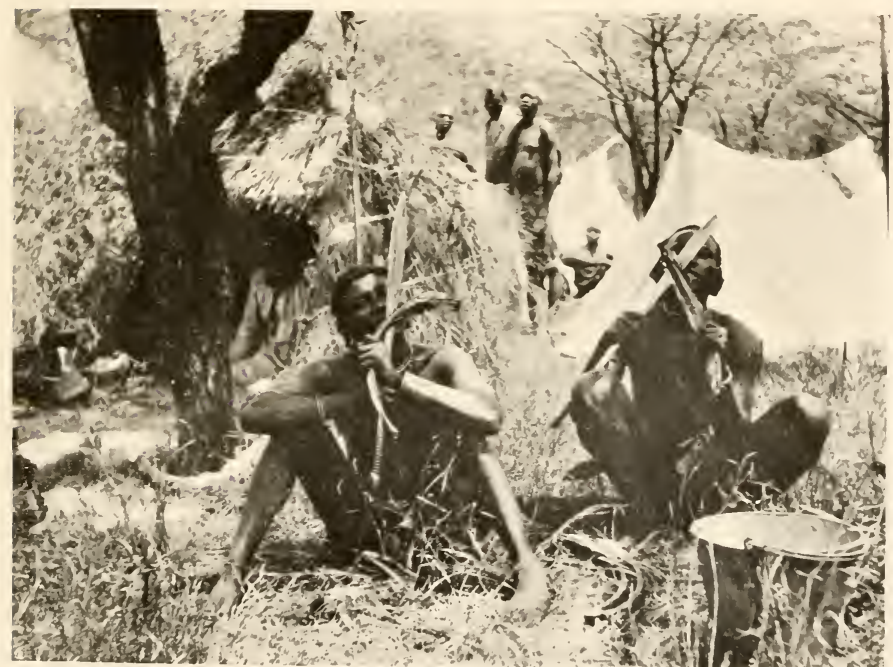

MY WANDOROBO HUNTERS 



\section{In Untrodden Paths}

which proved to be Mount Kilibei. As luck would have it, however, the rains had just set in, so we were by no means hard pressed for water at any time. In fact, at one place we had a little too much, and got a good bath into the bargain. The volcanic nature of the country in the Great Rift Valley causes it to be broken up here and there into vast cracks and deep chasms. We were marching along one of these gorges one morning on a sandy bed of a dried-up torrent. The sides were precipitous-composed of solid rock-where rock rabbits, the conies of the Bible, scuttled about from crevice to crevice. Hardly any vegetation was to be seen, except perhaps a few castor-oil plants, which seem to flourish in the barren rock without water in any shape or form. At last we came to a narrow opening in the gorge where the rock was too hard to have been worn with the rush of the raging water. A small stream trickled through it, with some bushes on the hill-side behind. Here it struck me to group my orderlies, as the scene would make a pretty picture.

I had taken the photograph here reproduced when we heard a low rumble. Mystified I asked my companions what it was, and they said it was probably thunder. Just at that moment, round a corner behind us came a moving wall of dirtybrown water. I had barely time to throw the camera into the branches of a thorn bush when 


\section{Big Game Shooting}

that liquid avalanche was upon us. To show how deep it was and the pace at which the water was travelling, I may state that it caught me high up on the chest, and before I had time to think we were all swept off our feet and carried helplessly along with it. We went for some distance before a slight unevenness of the rocks allowed us to scramble up, when, to my joy, I found that my orderlies, although badly scared, had not let go of my rifles or anything. It would have been somewhat excusable if they had, for the Masai cannot bear running water, and are in reality rather afraid of it.

In due course we arrived at our destination, Lanjoro Dis. Our camp was formed on the top of a flat spur sticking out of the mountain, covered with shady flat-topped thorn trees, and affording a beautiful view of hill and dale. All around us were lower peaks of the same range, thickly covered with grass and shrubs, with thorn trees poking their heads up at intervals. Towards the south, through a gap in the chain of hills, we could see in the far distance Arusia Mountain, in German territory, the pointed peak of which is snow-clad at this time of the year. Some ten miles away stretched Lake Natron, a soda lake, with Ngai Volcano, which is still active, at the end of it, also belonging to our Teuton neighbours. These lakes, I should explain, are of volcanic origin. On approaching them a thick 


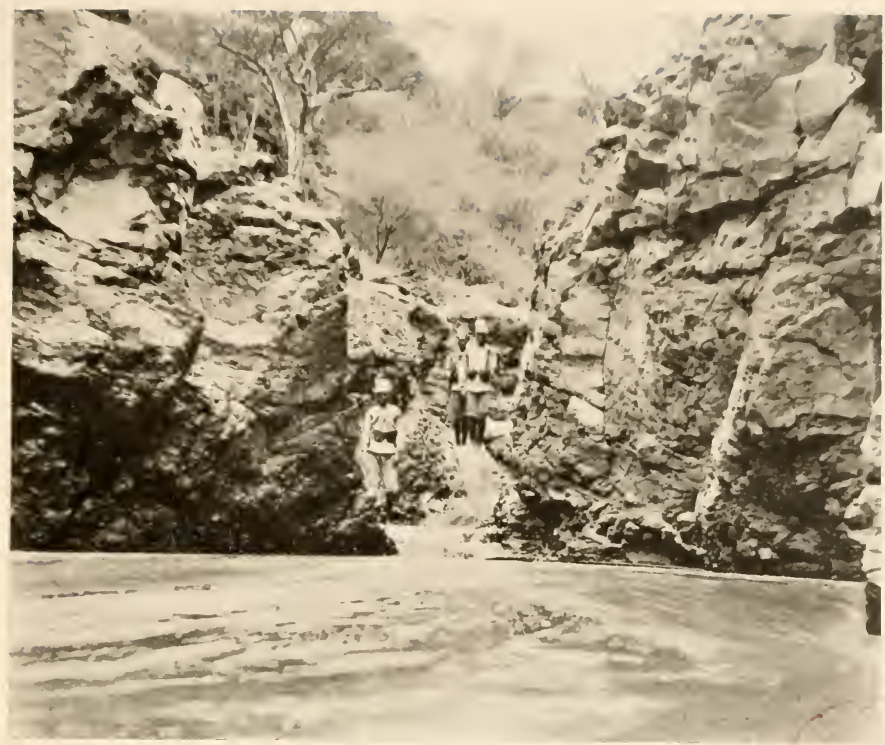

IN THE GORGES OF THE GREAT RIFT VAILEY

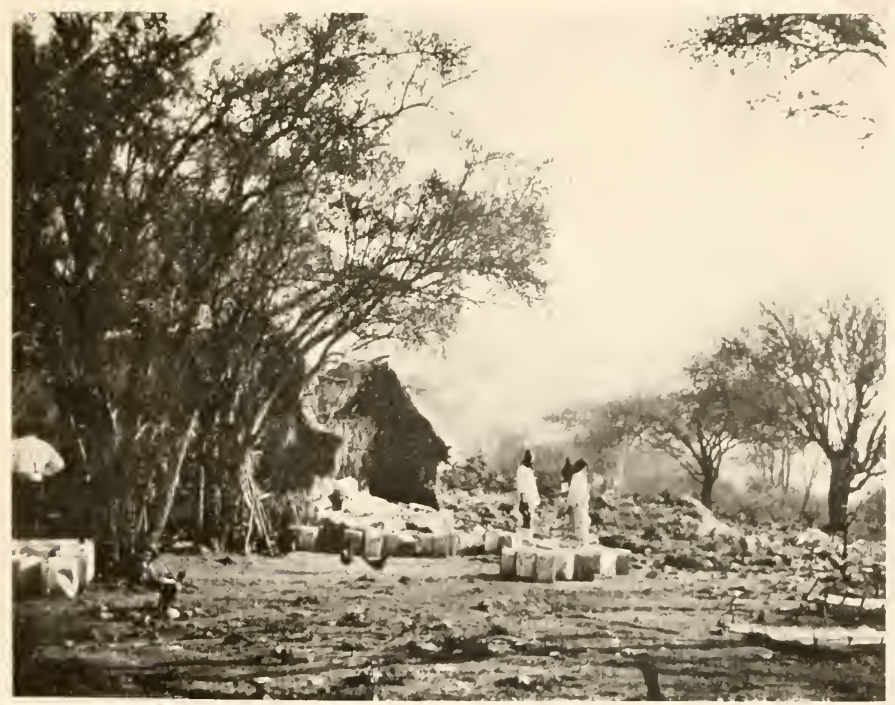





\section{In Untrodden Paths}

white scum is seen on the surface of the water, which, if skimmed off and allowed to dry, becomes some sort of crude soda. In the course of four or five days the scum collects again and the same process is repeated. The lakes smell horribly, and are fed by underground springs, besides the hot ones which trickle into them from the banks.

The camp itself was composed of the same sort of grass huts as we had just left behind us in the heat of the Guaso Nyiro. Now, however, there were "the rains" to contend with, and a nasty wind blowing, added to which we were some two thousand feet higher up. Something had to be done to augment creature comforts, and at last a bright spirit suggested that an empty kerosene oil tin, if it had holes punched haphazard all round it, would make a splendid extempore stove, provided the wood was cut small enough and the sparks did not fire the grass roof. The idea was at once vociferously applauded, with the result that many a chilly winter's night has since been enlivened with the genial warmth of that primitive stove.

The first night in the new camp was duly celebrated, the results of a buffalo hunt a few days previously providing the wherewithal.

Shortly after this I had the good luck to obtain some excellent photographs - difficult on account of the mists-of Mount Kilimanjaro, the 


\section{Big Game Shooting}

highest mountain in the African continent, nineteen thousand two hundred and sixty-six feet above the level of the sea. It boasts two peaks covered with perpetual snow; the higher is known as Kibo, and the lower and smaller is called Kibawenzi. Both peaks are in German territory, the frontier running round the base of both. Kilimanjaro means in Masai "The Mountain of the Great Spirit." The forests about its flanks swarm with elephant, buffalo, and rhinoceros, as well as with the pretty black-andwhite long-haired colobus monkey, whilst over the plains at its feet are dotted innumerable herds of antelope and gazelle, from the lordly eland to the diminutive dik-dik. Ostriches may be seen scudding before the wind with all sail set, and the guinea-fowl and homely partridge provide tasty delicacies for the pot.

I may add in conclusion that it will well repay anyone to visit East Africa for a shooting or even a sight-seeing holiday. To such travellers I wish the best of luck; may they have as good a time there as I did!

This article has been reprinted by kind permission of the Editor Wide World Magazine. 


\section{ELEPHANT}

ELEPHAS AFRICANUS

Swahili : Tembo. Masai: Ol-Le-'ng-aina.

7 HIS is one of those animals which it is needless to describe, but it is just as well to mention a few of the distinguishing points between it and the Indian elephant.

It stands much higher, say by two feet or so, and its footprints are therefore very much bigger. A fine bull's tusks weigh Ioo lb. each; they have been shot up to I $20 \mathrm{lb}$. or more, but between $60 \mathrm{lb}$. and $80 \mathrm{lb}$. apiece is a good pair, and a pair to be proud of. But the most noticeable difference lies in their ears, which are much larger and more ragged than their Indian friends'. I was told before setting eyes on one that an African elephant charging, with his trunk up and his huge ears stuck out on each side like studdingsails set on a line-of-battle ship of Nelson's time, screaming fit to burst the while, was about the most terrifying object to be met with in many a long day's march.

This magnificent beast "licks creation" through- 


\section{Big Game Shooting}

out the length and breadth of tropical Africa lording it over all, and smashing up thick scrub jungle into matchwood as he takes his daily promenade.

$\mathrm{He}$ is found, we will say, in a certain district twenty miles square. He may stay there for a fortnight, but never in the same locality. $\mathrm{He}$ and his attendants, two or three other bulls with fifty or sixty cows and calves, go feeding on, slowly, now halting when they arrive at their favourite trees for a bit, now making up for lost time whilst they pass something that doesn't taste so nice, still feeding; and then doing a sprint for some thirty miles if they have been shot at and thereby alarmed. It is very impressive to hear the crashing of the boughs as they wind their trunks round them and pull them down, then skinning them, so to speak, by running their trunks all along them; when the mass of foliage they have gathered describes a catherine-wheel as their trunks curl downwards and convey their food to their mouths.

An elephant never rests, according to our use of the word. He stands by day and stands at night, now eating, now trekking, and when he has got nothing to do he is sure to be mechanically switching the flies away with his great ears, and swinging a leg. That is a curious habit. He stands on three legs and swings the fourth. They cannot lie down on their sides except in 


\section{Elephant}

water, as they would be unable to rise again owing to their huge bulk, so they have to rest one limb by turns. That seems to correspond to our idea of sleep. They dearly love a bathe in water, where they are free from the stinging bites of mosquitoes, in a marsh for choice, and will stay in it for a whole day at a time up to their girths in mud, now and then squirting water over themselves. When thus occupied, as well as when travelling quietly, one may hear a peculiar rumbling sound, said to emanate from the stomach, and I believe it is undecided as to whether this is the cows talking to their calves or what it is, but the majority agree that it is only heard when they are, so to speak, happy, and unaware of any close proximity of danger.

It is very hard to distinguish the bulls from the cows when they are feeding, as one only catches a stray glimpse of a shining tusk or a twitching ear now and again, and the bulls are probably in the middle of the herd covering ten to fifteen acres, added to which the cows are on the outside, and usually very much on the qui vive. If a cow gets one's wind it is a decided nuisance, as besides standing the chance of a sudden and messy end, one is not allowed to shoot them (except of course in strict self-defence), and then, when one has so fired one's rifle to defeat the brute, the herd is off like a flock of sheep, crashing and tearing through the jungle in 


\section{Big Game Shooting}

any direction-the first that enters the leader's head-and as often as not bang over that unfortunate individual who loosed off; when the aforesaid "chance" is intensified unless there be a friendly tree (being strong and thick withal) near by. When once alarmed like that they will travel for miles and miles, literally, and they take some considerable catching, although their tracks are easy enough to follow, as a herd of seventy or eighty elephants split up into three or more parties, each in single file, makes a road one could walk along blindfold through the thickest jungle.

When badly wounded and they have discovered the whereabouts of their pursuer, they are the most formidable and most awe-inspiring animal to be met with in the world, and they say the most vindictive to boot.

For instance, very recently a sportsman was hunted by a wounded and fearfully enraged bull. He succeeded in climbing a small tree, and the brute, having caught his wind, and so located him, began to tear the tree to pieces, branch by branch, higher and higher, till he reached him. Again, an unfortunate gun-bearer was only saved by the elephant, who had been hit in the heart and was doing his final rush to work as much mischief as he could before going to the happy hunting-ground, falling dead with his trunk actually stretched out to seize the terror-stricken savage. 


\section{Elephant}

This is, par excellence, the animal which it is impossible to advise any man about with regard to a rifle. Some sportsmen use a 600 cordite, whilst a friend has recently killed two with one shot apiece with a 256 Mannlicher; but the majority use anything between a 400 and a 500 cordite, which, with a solid bullet, will be found heavy enough.

The head shots-No. I half-way between the eye and the ear-hole, sideways on, and No. 2 at the base of the trunk, end on, lower than a line between the eyes-will floor him. The heart shot, although virtually killing him, still may give him time to do no end of mischief.

If one kills a cow, one is heavily fined, besides having the tusks confiscated; but one is sometimes allowed to buy them back at a certain value per pound weight.

A rough estimate of the length of an elephant's tusk is that two-thirds of the total length is visible; therefore $3 \mathrm{ft}$. 6 ins. outside is a good big one.

Their feet are covered with large warts on the soles; the more and bigger they are, the older the animal is; so that on dry dusty ground one can see for oneself that one is pursuing a fine beast or the reverse. On other ground we must depend on the native trackers.

There are no tame elephants in Africa to the best of my belief. The reason why they have never 


\section{Big Game Shooting}

tried the "Keddah" system, which is in vogue in India, is because there is no market for them. It would not be worth while to tame them in India if the many rajahs did not buy elephants.

Elephants wander over a vast extent of country in the year, but natives ought to know roughly where they are to be met with in the different seasons. Wandorobo should certainly know. Sometimes it is in thick forest, at others it will be in thin scrub, and it is in this latter country that they are easiest to get at; and what is more to the point, in such country it will be found less difficult to distinguish the bulls from the cows.

There is one well-known herd which frequents Kibigori, near Lake Victoria, on the Uganda Railway; but they have been tremendously shot at, and so are very wary, as well as extremely vicious, in consequence.

They live all the year round in the thick bamboo forests on Kenia, Kilimanjaro, and the Aberdare range. The almost inaccessible Lorian swamp is said to be stiff with them, whilst there are any number in the Lorogi mountains beyond the Laikipia escarpment, and north toward Mount Elgon over the Guas-Ngishu plateau; but it is always rather hard to locate them. 


\section{RHINOCEROS \\ RHINOCEROS BICORNIS}

\section{SWahill : Kifaru. MaSaI : E-MUNY}

HE common two-horned rhinoceros
"looks very fierce, but is an awful
ass!"

That is what a small boy might say as a start for an essay at school, but it sums the animal up "in one," as they say.

$\mathrm{He}$ is like a large pig, black and hairless, has small pig eyes, and his upper lip has a prehensile tip to it. The curve of the lower jaw makes him look as if he were perpetually smiling. His horns are of a peculiar nature; the tips and two-thirds of the length look like horn till they are cut through sectionally, when they seem to be a mass of thickly coagulated hairs. And the fact that they are really composed of hair is borne out by their lower third part, from which the coarse ends of hair stick out till the base seems to be covered with cocoa-nut matting. Also when a beast is killed it will be found that his horns just move when pulled hard. They have to be cut off with a hatchet, bone and all, but after a day 


\section{Big Game Shooting}

or two the bone rots off, and in another week the skin goes too, leaving the base of the horn cupshaped. The rhino has three toes, which make his track easily distinguishable from the hippo's four-toed footmark. When he gallops he can travel much faster than he looks to be going.

$\mathrm{He}$ wanders about in an apparently aimless way, but usually deposits his dung in the same places for several days at a time, returning regularly about half an hour afterwards to spread it abroad with his horn and nose. I have seen him do this on one occasion, and it accounts for the long deep scrapes one sees in the ground. He can see very little twenty yards away from him, but his nose is very good. I have seen one begin to gallop three-quarters of a mile away on getting the wind of a caravan.

$\mathrm{He}$ is most alarming to look at, but-and it is a very big "but"- how often does he really charge in anger? I am sure-and most people in Africa will agree with me-that he gets so fussed at the first sound or smell of a human being that he starts galloping quite aimlessly before he can make up his mind where to go. Now if I suggest that it is not charging, I have got to prove it. First, What worries him? The smell of a caravan or human being. Why does he always go straight for a caravan or human being? Because, like most animals in the jungle, he runs away up-wind. (N.B. It is most un- 


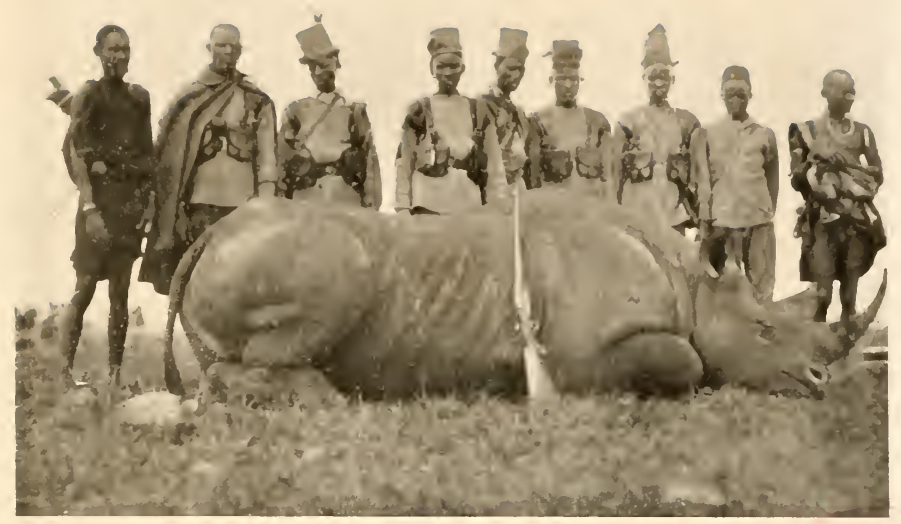

RIINOCEROS

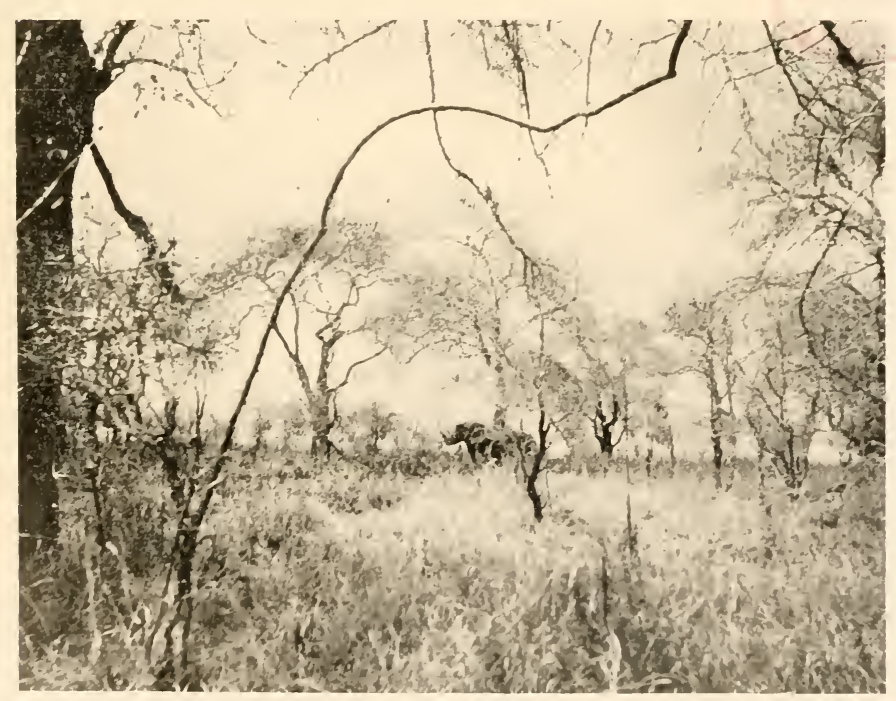

A RHINO LOOKING NASTY IUST BEFORE CHARGING 



\section{Rhinoceros}

fortunate for the caravan that it should be upwind! If it wasn't, how could the rhino scent it ?) Q.E.D.

On these occasions porters hurl their loads (they have no brains, or these would go too) into oblivion, and shin up trees. Every one who is armed loads in a desperate hurry. Master shouts for his big rifle, and everybody is on the qui vive to see what is going to happen next.

It is true a beastly rhino, on a similar occasion to the one depicted, came across my own roll of bedding, and actually charged it from a distance of exactly two yards, and what is more, he knocked spots off it. He tossed it, and finished by sitting and rolling on it, thinking, no doubt, that there was one man less in the world. I laughed immoderately.

On another occasion I had just lined out some hundred Masai armed with spears and shields to rush a hostile village, when a rhino turned up, going like smoke. It was most interesting to see how little they made of it. Eight or ten skipped out of the way. He passed through the line, and I saw him still going strong in a cloud of dust two solid miles away on the sky-line. This took place on the River Tana under Mount Kenia.

The funniest thing I ever saw connected with one of these antediluvian beasts was when five porters had with great difficulty climbed, and 


\section{Big Game Shooting}

were sitting in, a very flimsy thorn tree, and were hanging on by their eyelids. The rhino, unfortunately for them, couldn't see the tree, and by a great mistake hit it with a leg in passing, and must have been more than horrified to find five fine fat porters come hurtling past his ears, having been shot out like so much rotten fruit. No one was damaged, and I am sure the rhino must have been more frightened than any one.

It is quite true that on certain occasions they are really nasty, and do charge in a most vindictive way. A great friend of mine had the misfortune to lose his arm thereby. Doctor Kolb lost his life in a similar manner, and I know of a case in which a poor old native woman was charged without provocation and was killed. I myself was charged once. I met a rhino running away from the caravan, and thought he was doing a charge. I fired at fifty yards, and stupidly hit him too far back. That was all he wanted. He was hurt, and charged the flash, having discovered where I was. I found I had only one cartridge left with me, so had to let him get to fourteen yards to make a "cert" of him through the neck.

A cow rhino with a young one is, of course, quite different. She is a real brute.

Again on Laikipia plateau, I was being taken by some Wandorobo (excellent local hunters) to a place for eland. I appeared carefully and 


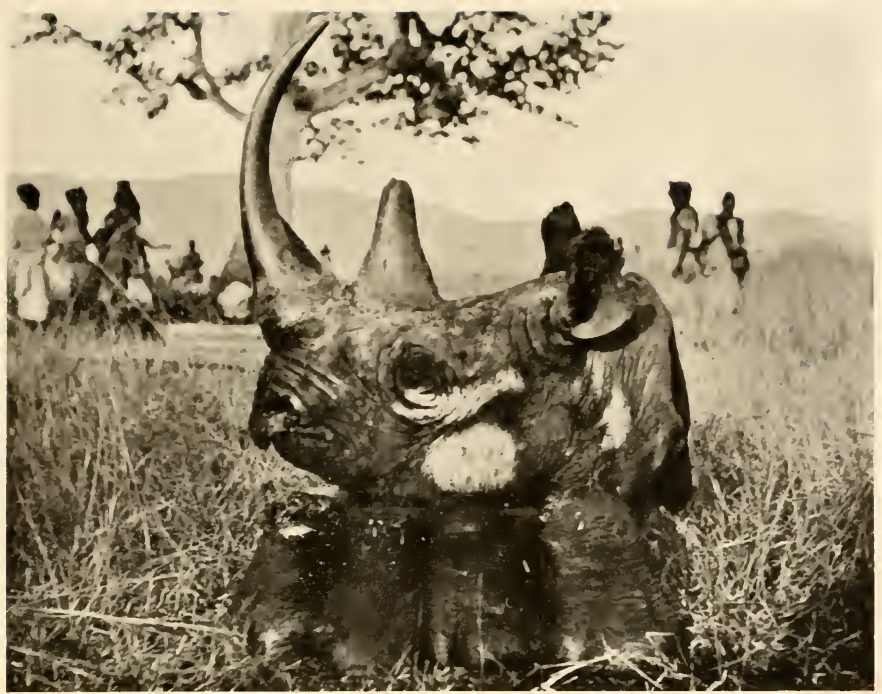

A GOOD HEAD

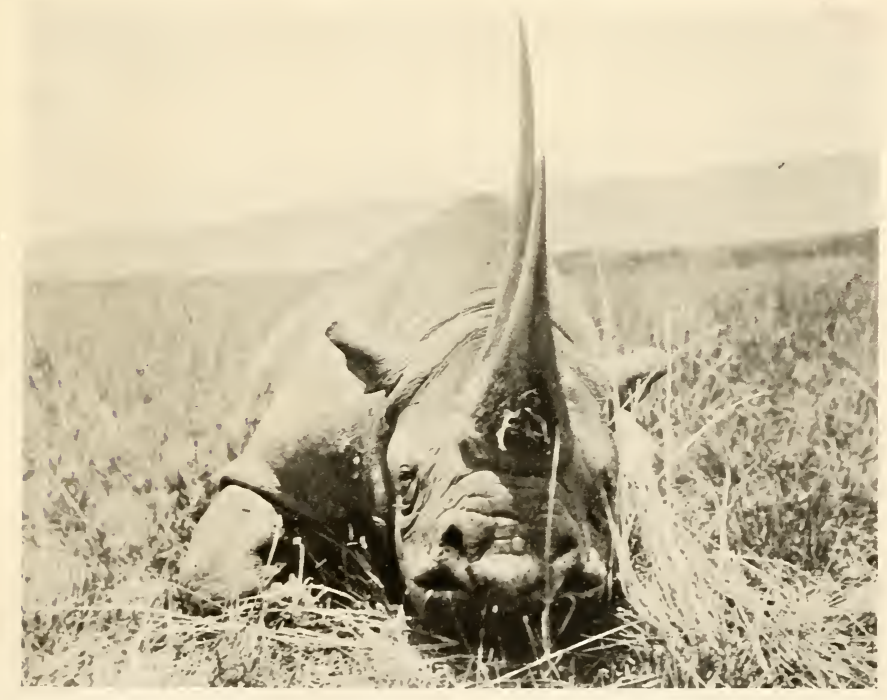

AN ABNORMAL HEAD. THE BACK HORN IS IONGER THAN THE FRONT ONE 


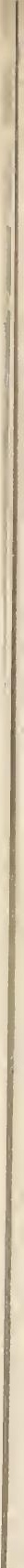




\section{Rhinoceros}

quietly from some thick bush, and was horrified to find myself surrounded on three sides by four rhino, the nearest twenty yards, and the farthest fifty yards away. All had got my wind, and had their heads up. I did not like taking on the chances of four rights and lefts, added to which I did not want a rhino at all, as the eland ought to have been round the next corner (and were). I hoisted the white flag, and thanked my stars when I had got clear.

Their hide is a good inch thick, and polishes with oil and sand-paper till it is quite transparent. Table-tops made of the skin look very well, and whips and sticks are also admired. The whip is the toy with which punishment is administered to the naughty porter, and is misnamed "kiboko," that being the native name for the hippopotamus. A short horn is worth keeping, as it makes a firstrate inkpot or paper-knife. The bull has a thicker horn and usually a shorter one than a cow's, which sometimes grows to a yard in length.

On the Tana River they drank at 5.30 a.m., fed till ro a.m., and appeared again after their siesta at about 4 p.m. On Laikipia they seemed to sleep less in the middle of the day. On the Guaso Nyiro, on the German border, I only saw a small one, although I know for certain that there were some huge ones there. In that district they always fed in the night, and had gone to lie up in the thick stuff by 5 a.m. My friends 


\section{Big Game Shooting}

saw them, and I their traces, but I could never set eyes on the beasts themselves. Their times of feeding differ according to the heat or cold of the various districts they are found in.

The first time I ever shot one in East Africa I thought I had got quite close enough, sixty yards, but that did not please my Masai orderly, who seized me by the arm and made me go to twenty-five yards before he was satisfied. I did not like it one little bit, but I found myself under his orders and so had to do it. Nothing happened, of course, except the death of the rhino, and my terror of them disappeared from that date, although they are awkward-looking at times.

They are found almost all over East Africa, though they are not so numerous near the dwellings of men as they used to be. From Kiu to Kilimanjaro, on the Tana River, and up north on the Guaso Nyiro are their favourite localities apparently, and they are found round Lake Natron, on the Laikipia plateau, up to Lake Baringo, Kitui, and all down the German boundary.

A good average front horn is twenty-eight inches. 


\section{A RED-LETTER DAY}

NE day, at the beginning of February, on my way from Nairobi to join the Anglo-German Boundary Commission, during a march of five days, I had an afternoon's shoot which is worth while recording. Some twenty-five miles from the Soda Lake, Magardie, which the East African Syndicate are proceeding to develop, we had stopped for the day at a large water-hole at the foot of one of the mountains of that district, to camp for the night.

The country in this southerly part of the Rift Valley greatly resembles North Somaliland in several ways, in its bare and desolate character in the hot weather, as well as in its vegetation and animal life. The stony plains, sparsely covered with burnt-up grass, trees, and low umbrella thorn bushes, clumps of "hig" aloes and cactus, and the bare, rocky mountains of a volcanic nature, bring back old scenes in the campaigns against the "Mad" Mullah very vividly. The greater kudu is there, although I did not come across any, and so is the Waller's 


\section{Big Game Shooting}

gazelle, or gerenuk, of which I secured a fine specimen next day. Lesser kudu I did not see either, but he would not be very far away, to complete the similitude.

After a hasty lunch of various tinned odds and ends, I wandered along the valley for some distance before turning up the hill-side, and on rounding a corner in the low scrub of thorns and high grass, surprised a couple of rhino, one wallowing in a small mud bath, and the other looking on, evidently waiting till "pa" had finished and his turn should come. They were neither of them more than sixty yards away, and jumped up at once, snuffling and grunting, and apparently highly annoyed at their privacy being disturbed.

Rhino have notoriously very bad eyesight, and rely almost altogether on their sense of smell, for which reason I fancy that they had got a strong puff of our wind, but had not actually seen us. It was awkward for a moment, as one never quite knows what a rhino will do next on being disturbed; however, I reached my hand behind my back for my big rifle, in case of accidents, and stood motionless, waiting for what might happen. As usual, they both made tracks straight for where I stood, most likely running away up-wind, as is their usual custom.

Now a rhino is a nasty-looking thing as he comes galloping up, puffing like a steam-engine, 


\section{A Red-Letter Day}

and swaying his head from side to side to try and find out more about what has frightened him. He looks something like what I have heard described as an ironclad let loose at full steam ahead with its steering gear gone wrong.

There was nothing to do in this case but shoot, and as they were so close I knew there would be precious little time for reloading, in case either or both were not knocked over with one shot apiece.

However something had to be done at once, and there was no friendly tree to get behind into the bargain, though if there had been a tree near it might have added to the predicament, since if I had got behind it they would have been bound to spot the movement, whilst as it was there was just the chance that they had not as yet seen anything definite. My Masai gunbearer behaved splendidly, and neither moved nor shouted. The first rhino was coming in a bee-line in my direction, and being by now thoroughly alarmed on getting our wind strong, luckily had his head well down, so that I could get in a shot with my 400 cordite over his head into the junction of his neck with his body. $\mathrm{He}$ must have been about thirty-five yards away when I fired, and, as luck would have it, I hit him where I wished, and dropped him in his tracks, throwing up dust and grass, whilst squealing like a stuck pig. 


\section{Big Game Shooting}

There was no time to trouble about him, however, as Number Two had seen where the flash of the cordite came from, and the bang of the rifle as well as the downfall of his pal had angered him, so he certainly did put all his weight into an outright charge, and was in fact "out for blood."

It is very little use trying to dodge a rhino when he means business, as in spite of his ungainly bulk, he can turn like a polo-pony; so something very much to the point had to be done with the one cartridge remaining in the rifle, without further delay. He gave me a rather more difficult shot, as for the first twenty yards there was a thin bush between me and him, and it would have been madness to chance my last shot through this bush; but he would have to port his helm a trifle to round the obstacle, giving me a side shot in so doing, and I waited for that instant.

It turned out as I expected. I got the rifle up and drew a careful bead, and in the twinkling it took him to slew outwards, caught him fair and square in the base of the neck, raking him from stem to stern, and flooring him on the spot, eighteen measured yards away.

A neck shot always drops an animal, but I had got my friend in the heart as well, so there was only Number One to finish off. I had not wanted to shoot them particularly, as their heads 


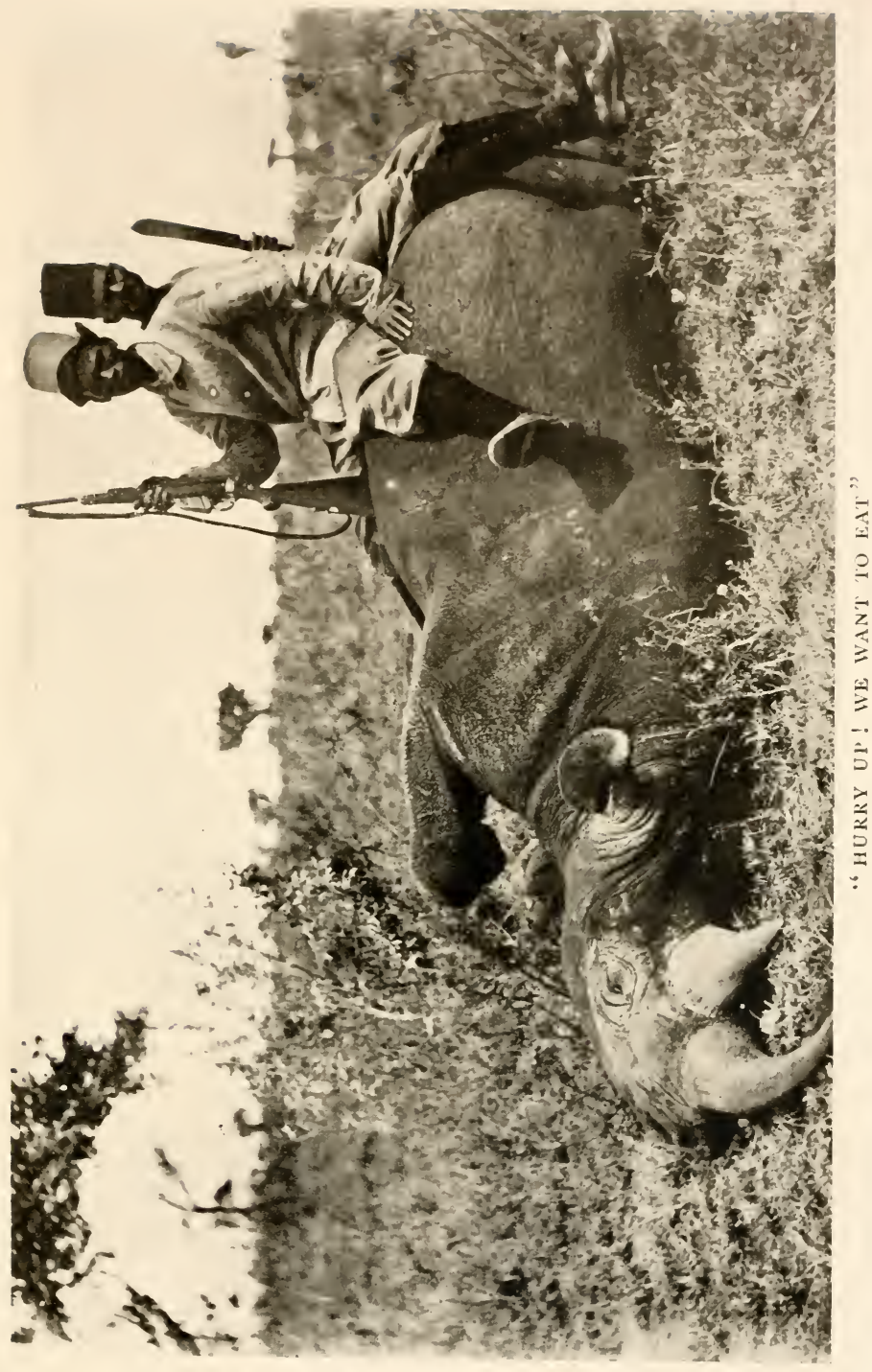




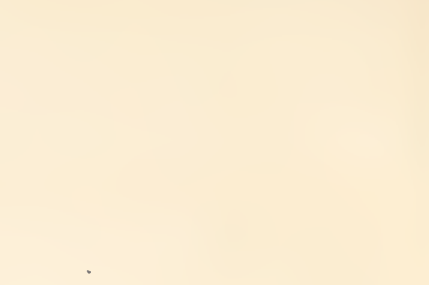




\section{A Red-Letter Day}

were not specially big, but the dreadful deed had to be done in self-defence. It is somewhat startling to be suddenly set upon, in an absolutely unprovoked attack, by a couple of unwieldy monsters who mean serious business; one would have been bad enough, but two together without any warning makes one think a bit.

However, there was ample meat for my men, and rhino-tail soup for master, but I wanted meat as well. After a short detour on the lower slopes of the hill before returning to camp, amongst some bushes, in half an hour or so, I came upon two antelopes of the dik-dik species, standing together about eighty yards away in a small clearing. I had my Mannlicher with me, and, sitting quietly down, put a lucky bullet behind the shoulder of the nearest, killing him instantaneously. His pal stood motionless, as they will often do for a few seconds, which enabled me to reload, and by great good fortune I shot him as well. I paced the distance and found them both quite dead. There was meat for me without further trouble.

The dik-dik is almost the smallest antelope in Africa, standing about eighteen inches at the withers, and is very good eating.

I had thus killed with two rights and lefts, within half an hour of one another, specimens of almost the biggest and the smallest animals in 


\section{Big Game Shooting}

Africa, and was back in my tent within three hours of leaving.

Needless to say, the singing and noise in camp that night was enough to wake the dead; and some of the porters were unable to march next day owing to the overdose of meat. 


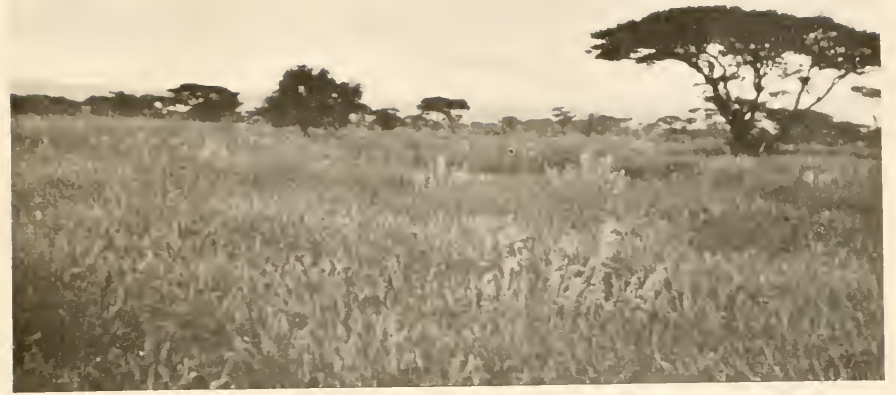

RHINO GROEND WITH KIIINANJARO IN THE IISTANCE

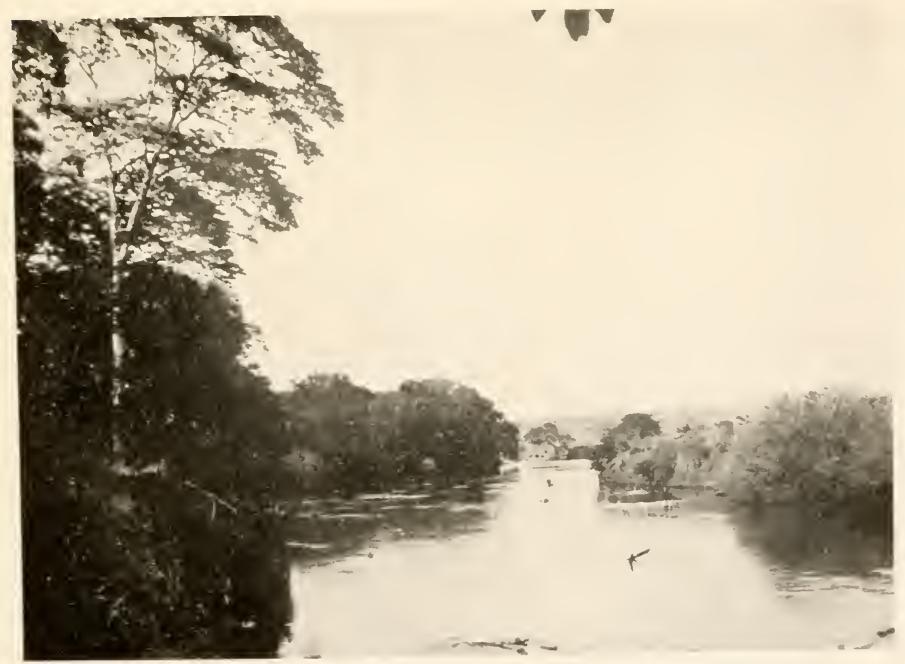

A FAVOURITE HIPPO POOL ON THE TANA RIVER 



\section{HIPPOPOTAMUS}

\section{Swahili: Kiboko. Masal: Ol-makaU}

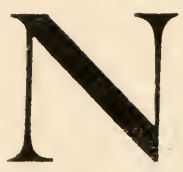

TEXT to the elephant, the largest inhabitant of the African continent.

He has an unwieldy head with a great square nose and mouth, and his eyes and nostrils, when his head is held at a certain angle, are the only projections above the water. The beasts sink, and rise again to blow, every two minutes or so continually. Their voices are to be heard booming by day like the bass pedal of an organ; they make no noise at night, as they are out on the banks of the river or lake feeding on the grass and riparian vegetation.

To kill a hippo he must be hit in the brain, i.e. the usual place half-way between the eye and the ear. He then sinks at once, and will float earlier if hit in the evening than in the morning, because his last night's food is digested, and he is consequently fuller of air. One wants to have men constantly on the look-out for his carcase when it rises to the surface.

I am told that when found on land feeding they are only dangerous when the pursuer is 


\section{Big Game Shooting}

between them and the water; and then only, I should imagine, if they tripped and fell over one. Three solid tons is rather an effective roller.

When they are shot in the water from a boat, beware! They have a very nasty habit of pursuing the said boat; and one crunch with their huge jaws smashes the concern to matchwood. A steel boat on Lake Albert was recently charged by one, and the shock started a three-quarterinch plate so badly that the occupants only just managed to get her ashore before she sank. They are more likely to fall foul of a boat if one is launched on a place where few boats have been before, probably because they approach to interview the new intruder and consequently get hurt with a bullet. They are no mean adversaries in their element.

Their backs are sprinkled with longish hairs; that is to say, on seeing one at close quarters out of the water in broad sunlight on Lake Naivasha he seemed undoubtedly to be so covered.

I have shot one in the Tana River, but having rolled over three or four times, he sank, and I never recovered him.

That river is full of big crocodiles, and I expect he got stuck in a hole, and was devoured by them. I had the top and bottom of the pool watched continuously for two days, and he never appeared. 


\section{Hippopotamus}

As I say, shooting them from a boat is most exciting, not to say dangerous, as if the boat is upset-"Bus! Hogya!" as they say in India.

They are found in lakes Naivasha, Baringo, and Olborlossat, as well as in all the big lakes, and on the Tana, Mara, and Kiboko rivers, and also in some marshes at the foot of Kilimanjaro.

A good tusk is thirty-two inches in length. 


\section{GIRAFFE \\ GIRAFFA CAMELOPARDALIS}

Swahill : Twiga. Masai : Ol-o-ado-kiragata

T $\mathrm{N}$ proportion as the buffalo's sense of hearing is so well developed, so is the giraffe's sense of sight.

Bar none in the jungle he has the most extraordinary eyesight. It is extremely seldom that you will see a giraffe before he has seen you. And I do not think that that is necessarily on account of his great height. They seem to have the faculty of detecting moving objects. At eight hundred yards and a thousand yards' distance one will just see them quietly cantering away (if their gait can be so described) for that reason.

With their wonderfully long neck, which seems to bulge slightly forwards at the junction with the shoulders, their high withers and sloping back, and then their long legs into the bargain, they are a reminiscence of a prehistoric peep.

When moving at what seems a slow sedate canter, hardly placing one leg before the other apparently, they are in reality covering the ground to some purpose. Finally, their haughty 


\section{Giraffe}

way of observing one from over the top of a tree makes them look most absurd animals.

The bull is the biggest in the herd, and distinguishable, as he is darker than the rest. As is well known, they are splotched with big chestnut marks, separated from one another by narrow white lines. Their colour varies very much, from an almost blackish bull to a brilliantly marked fawn-coloured cow. I think that the fact of their various colourings being lighter or darker bears not the smallest relation to their different species, but a cow is always much lighter than a bull.

I have met with the five-horned as well as the three-horned giraffe under Kilimanjaro. The former carries five horns, all covered with skin; two in the usual place about four to six inches long, and a third attempt at a horn nearly as low as between the eyes and shorter, and two more horns growing from the back of his skull behind his ears; whilst the three-horned variety is without these two latter horns.

He likes fairly open or thin bush country, with plenty of thorn trees, which form his staple food.

I have never seen one drinking, nor have I seen their tracks round water.

I have come across them in great numbers round Kilimanjaro, in herds of from four to ten, and I know of one instance of over fifty-two, but that last is quite out of the common. They are also to be met with near the Thika-Thika and Tana rivers, and north of Lake Baringo. 


\section{$\mathrm{LION}$ \\ FELIS LEO}

Swahili: Simba. Masai : Ol-ngatuny. Ol-owaru-kitok

T would be absurd on my part to go in for a lengthy description of this enormous cat. Everybody knows all about it from their nursery days.

It is, I fancy, more or less of a fallacy to suppose that there are different species in Africa, as on any one having shot one, a rider is always added to the story of his death: "A splendid black mane," or "No mane worth talking about." A good mane is a matter of luck.

I have only been in at the death of one lion in British East Africa. We came upon him near Lake Hannington quite unexpectedly ; my friend stopped him with a split Mauser in the neck, and I raked him with a 400 down through the chest.

In Somaliland I had great sport one morning, which is worth describing, as the methods were peculiar to that part of the world and to the chief who ran the show. I think any one who has been in the locality must have known and 


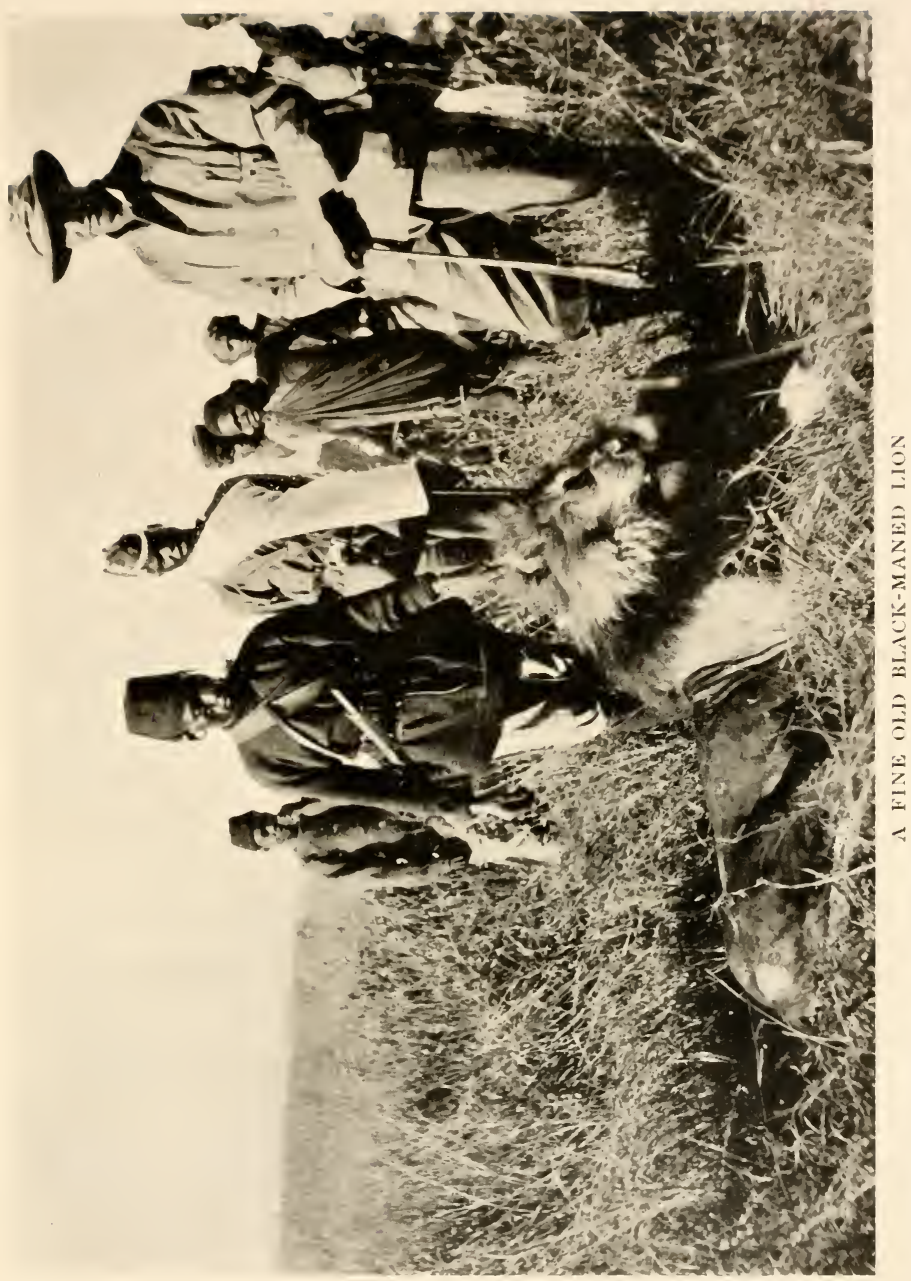





\section{Lion}

made friends with one Askar Gerad, who lives west of Hargeisa-a tall man with a huge aquiline nose, and a good chap to boot. His brother and company on horseback having located a lion in a patch of dry grass and bush, the procedure was as follows. I was posted down wind of the patch and fairly close. Near me was a man mounted on a white pony, about sixty yards from the bush and also down wind. The local savages then lighted the grass to windwards and made a fearful hullabaloo. After five minutes or so I saw the lion, indistinctly, moving on my edge of the grass. A moment later, when things were getting too hot for him, out he dashed past me and my gun-bearer, going straight for the pony. The rider was quite ready, of course, and galloped off. I had a nice side shot as he was crossing my front at twenty yards or so, and floored him. The idea is, they say, that a lion under similar conditions always goes for an animal (which must be a speedy one in case the lion is missed) rather than for a mere man on foot. I should say that now and again the notion might fail, but it certainly came off then, and is Askar Gerad's usual method of hunting lions.

This is rather a digression, however, as hardly had the lion bit the dust than his mate turned up, this time charging the gun-bearers, who had run to the carcase of the first one. I was walking quietly towards it, and, luckily, had my rifle 


\section{Big Game Shooting}

still in my hand. I was not, however, able to save "grief" altogether, but did prevent what might have been a very nasty thing. The lion got it in the heart all right, but before he actually died his death-rush carried him into the midst of the crowd: but he only succeeded in knocking down a couple of men, whereas there might have been a very nasty mauling for some one.

It is very hard to place lions in any particular localities in East Africa, except on the Athi Plains and round Kiu Station on the railway, as they are to be found practically anywhere where there is plenty of game, throughout the length and breadth of the country. 


\section{OTHER CARNIVORA}

7 HE leopard, cheetah, and serval come under this heading; and although they are to be met with, and are found in fair numbers all through the country, they are so very rarely seen, only now and again, and that generally by good luck, that it is hard to say much about animals that are so well known to many sportsmen in other parts of the world as well as East Africa.

The cheetah can be told at a glance from a leopard by his build, which compares to a leopard's as a greyhound's to a cat's. They are almost the same size as one another, however. When the skin is lying before one the distinction is easier still, as the former, again, is covered with smallish black spots, whilst the latter has black irregular rings instead. To continue, the cheetah's claws are non-retractile like a dog's, and the leopard's disappear at will like a cat's. No mistake ought ever to be made in this latter difference.

A serval is a smaller edition of a leopard, but very high on the legs and short-tailed, and is a true cat; only short streaks take the place of the leopard's spots, and seem to follow one 


\section{Big Game Shooting}

another in rough lines along the back and flanks.

The leopard frequents thick forests, and is seldom seen or heard of till the evening and night. The cheetah prefers more open jungle, not to say thin bush, as he does more stalking to get at his prey (finally catching the unwary one with six or eight huge bounds) than the leopard, who waits in a bush until something comes along-for choice one's favourite spaniel. The serval is often to be met with right out in the open in long grass. The Nairobi foxhounds come across one frequently, when it makes a bolt to some big tree that is handy and shins up it in no time.

Leopards generally do their hunting singly, but not so cheetahs. On one occasion in Somaliland I saw three of the latter together doing a most diligent stalk towards a herd of antelopes. Unfortunately they saw me and galloped off, otherwise I should have been in for a very pretty sight. I have heard of another case when five were seen together, trotting along in single file, seeking for something to devour. The native princes in India use them for stalking blackbuck with. It is, I am told, a very interesting and pretty sight to watch. Those they use in India are not more than half tame, and can never be altogether depended on; but the leopard, on the other hand, like the bear, can never be tamed, so they saythey are bound to turn savage before very long. 


\section{Other Carnivora}

The leopard is very fierce, and many authorities hold that it is more dangerous than a lion or a tiger, and it certainly is endowed with enormous vitality. They are worse nuisances to the colonist in East Africa who goes in for sheep and cattle ranching than the lion. When one hears a lion roaring it means that he has fed; otherwise the tremendous noise, that can be heard for miles on a tropical night, would put all the game on the qui vive; but the leopard never makes any noise at all at night, sneaking all round the place and looking for a hole to get in at. The only noise he makes is sometimes by day, when he may be heard coughing in his den right up on the cliff side in a mountainous district. A man-eating leopard is a distinctly nasty animal, as he goes about it in such a stealthy manner.

The leopard and cheetah are found anywhere and everywhere, but are, as I said, usually come upon by chance. 


\section{GREATER KUDU \\ STREPSICEROS KUDU}

Swahili : Malo m'kubwa. Masai : Malo

68

THE finest antelope in the world, bar none!" is how I first heard this species described, and I am sure most people will agree. It is, I suppose, allied to the harnessed antelope, but it is of a slate-grey colour instead of the bright red which characterizes the above. The body is string-marked down the flanks, but is rather scantily covered with hair, and it has a beard all the way down the neck. Its splendid horns make complete spirals, and when set up with its mask, in which the white chevron meets over its nose, together with three white spots on its cheeks, it forms one of the finest trophies imaginable. The does carry no horns.

I cannot claim to have shot one in this country, as it has not been my luck to get into the Baringo or Rudolph countries, where there are a goodish few, and in all other districts it is preserved. They are also to be found in German territory. I have shot them in North Somaliland, however; 


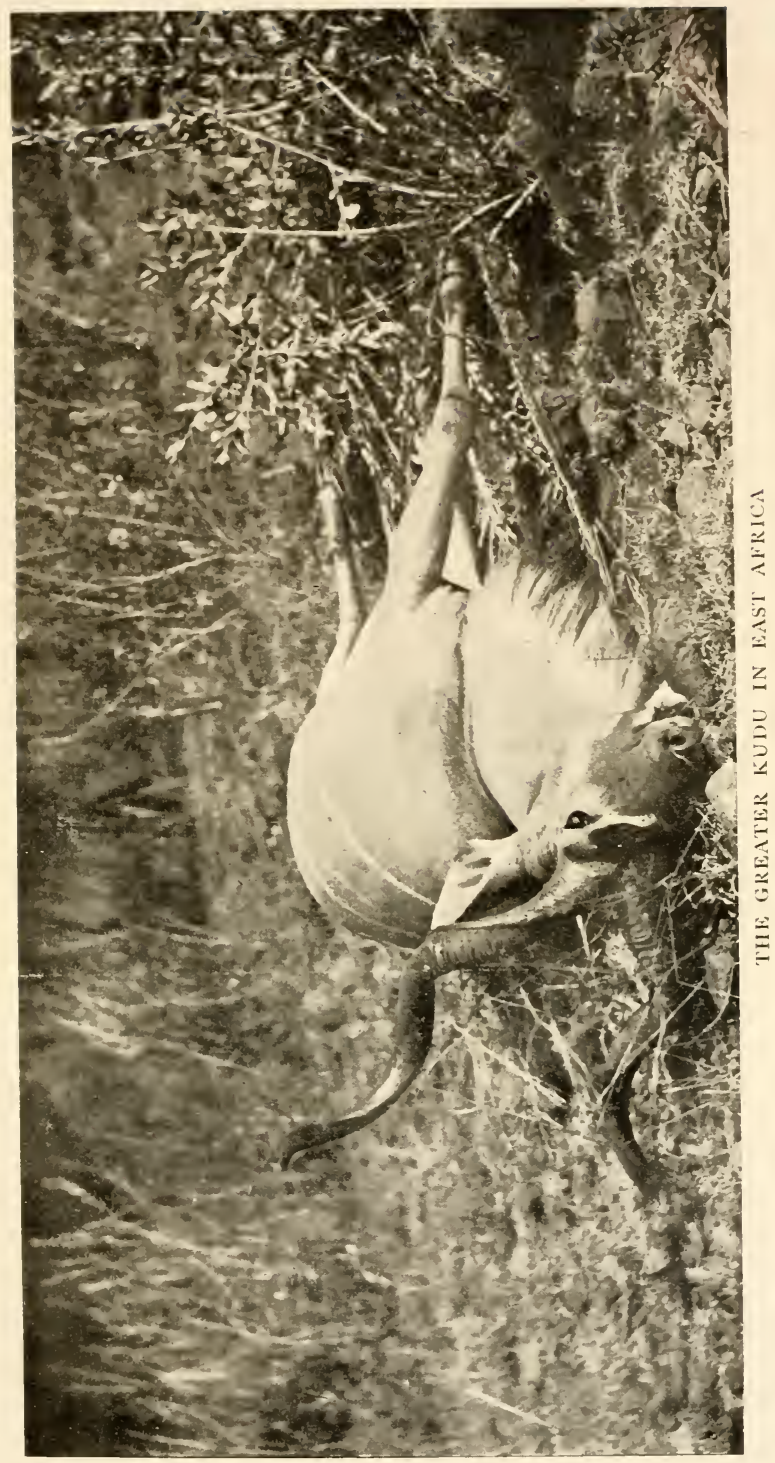





\section{Greater Kudu}

and as they deserve a place in my book, I put them in this.

They frequent high hills, nice and rocky, with plenty of ravines and bush jungle. I always tried, besides keeping my own eyes and those of my shikari very wide open, to stalk any big tree that came in my path on the Golis Mountains, as they were so often disturbed from the shade of one, till I discovered that tip. They can move over bad mountain ground to some purpose, and they possess great acuteness of smell and hearing.

In Somaliland I used to keep a couple of natives on the look-out for them-one to keep one marked down, and the other to bring in the news. A wild man would rush into camp and say he had found a monster, stretching his arms wide apart in his endeavour to show me the length of its horns. Alas! many was the long, difficult, sweating trek from which I returned, having found the animal was a small one, before I discovered how beautifully the native can lie. But then, all natives are brought up to "exaggerate" as a fine art! On giving news of a rhino the savage stretches out an arm and invariably puts the palm of his other hand into his armpit, saying with a beatific smile, "So long!" However!

One male kudu keeps company with, say, six to eight females as a rule. A solitary bull is sure to be a good one. They wander a fair amount and are not "local." They drink every day, but 


\section{Big Game Shooting}

all round the country and not necessarily at the same place; and at odd times of day, as I have seen different ones drinking at the same stream on four different times of day.

It is a case of taking one's lunch out and making an all-day job of it and no mistake, with the greater kudu, and it is no "cert" then by any manner of means. A friend of mine keeps a special pair of boots with rhino-skin soles for stalking them over the rocky hills.

They live up in the hills all day, and wander down lower at night to feed, so the very early morning is the time to see them, but one must be there in time for that.

A decent head will measure fifty inches round the front curve. 


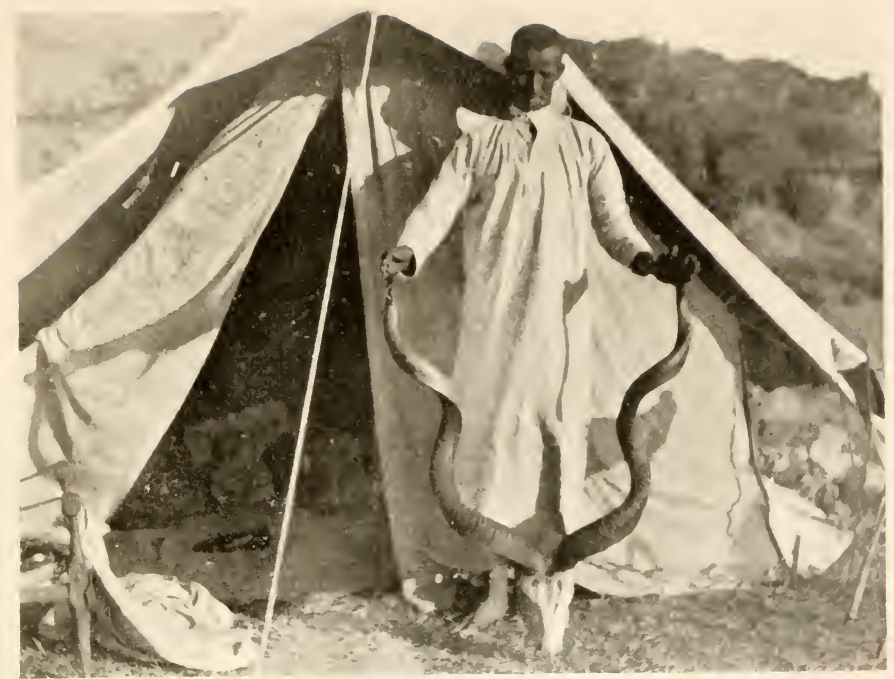

GREATER KUDU IN SOMALILAND

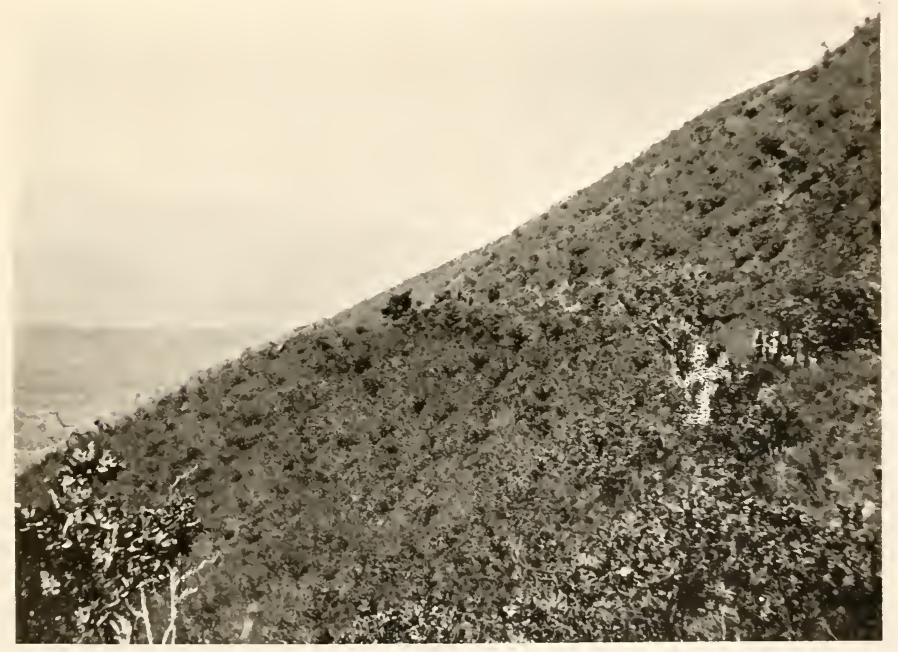

GREATER KUDU COUNTRY NEAR LAKE BARINGO 



\section{LESSER KUDU}

STREPSICEROS IMBERBIS

Swahili: Malo n'dogo. Masai: Malo.

7 HIS miniature of its peerless brother, the greater kudu, is an animal well worth adding to any collection, as much on account of its beauty as owing to its shy and retiring habits.

It is of a greyish sandy colour, and has a rather fluffy or shaggy coat, with several narrow, white, string-like vertical lines down its flanks, and also a bushy tail. Its legs are of a distinct fawn colour. Its head is of a still darker colour, grey almost verging on black, with two or three small white spots on the cheeks, but the white chevron in the lesser kudu does not meet on the bridge of the nose. It has a thin mane and two large conspicuous white crescents under the neck. Its ears are very large for its size. Its horns are shorter, have a closer spiral and a smaller divergence than the greater kudu; the does carry no horns, as in that species.

The lesser kudu buck is found by himself, and 


\section{Big Game Shooting}

also with a few, never more than two or three, does in his company.

In Somaliland they like thick bush and are plentiful amongst the thorn trees. and patches of "hig" aloes on the lower slopes of the Golis Mountains, as well as further south round Kirrit. In East Africa they are rather more exclusive, only, I think, being found round Kismayu, and then near Teita and Kilimanjaro, going as far north as Lake Magardie.

They do not seem to bother themselves much on being disturbed, as they stop and peer at one from behind bushes and trees constantly, until thoroughly alarmed, when they gallop off amid the bushes and over the stones to some tune, and go as if they meant keeping it up. I have seen them in rather bigger herds in Somaliland, but I am dealing now with East Africa.

Although Kilimanjaro cannot be anything like shot over so much as other places, lesser kudu are rare, and so one wonders what happens to the calves, or whether they breed so prolifically as other game.

They are to be found sometimes out in the open, under the shadow of a big tree at midday; but this is lucky.

As a rule they feed in the plains (if there are any) at night, and by eight o'clock in the morning they are higher up in the cool.

"Lesser kudu country" is a well-known term, 


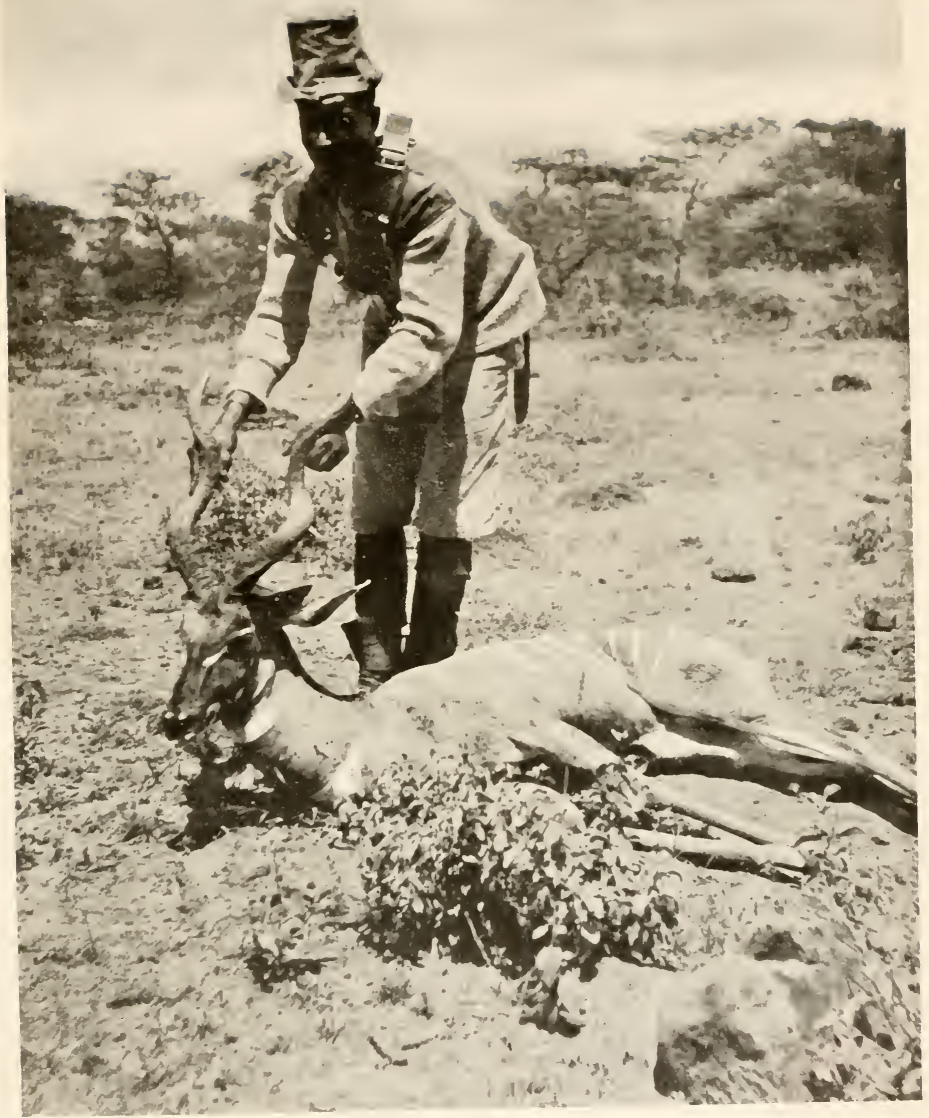

LESSER KULE 



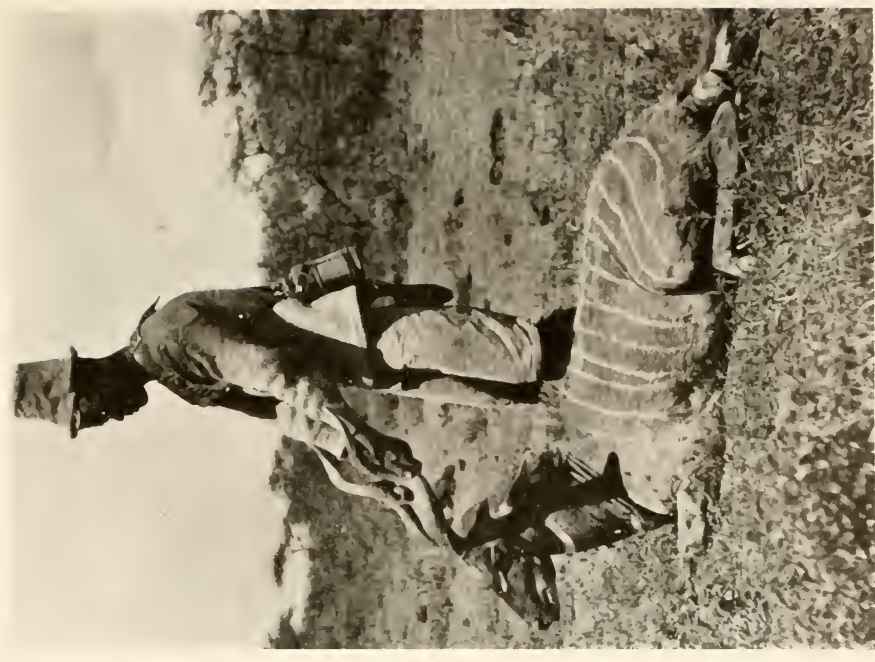

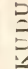

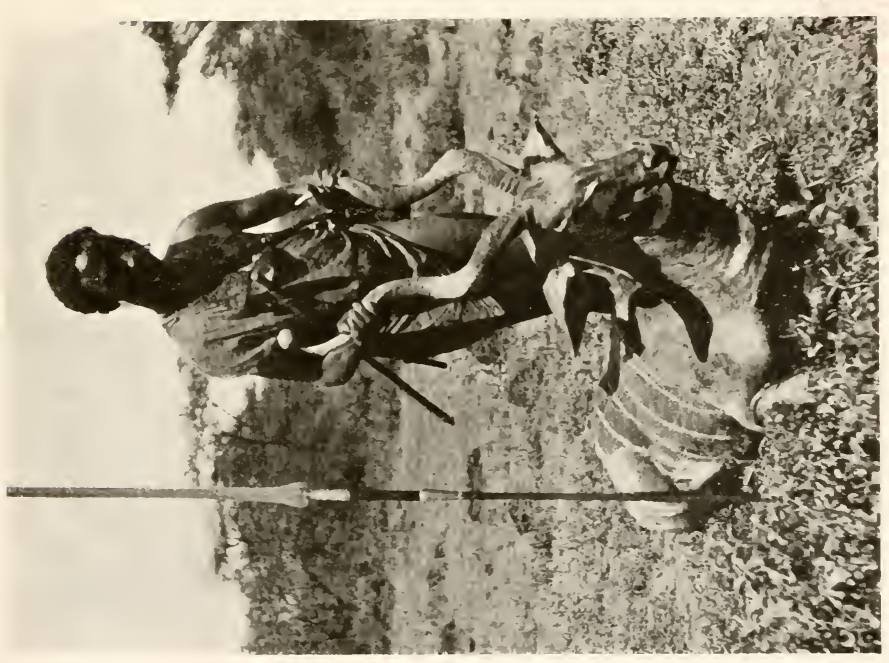





\section{Lesser Kudu}

and, if once shown one, it is not hard to recognize in another land. I am sure that this is correct, as it was corroborated recently by a friend, who used almost the same words.

These antelopes are rather more confiding to get at than some other animals I have met in the same thick bush country.

A twenty-eight-inch head is not bad. 


\section{BEISA ORYX \\ OR YX BEISA}

Swahili : Cheroa. Masai : Ngimosorrok

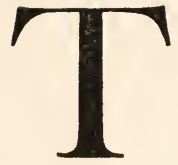

1HIS is an antelope whose distribution in the north of Africa is very wide; from Hargeisa, in North Somaliland, to as far south as Laikipia.

They stand about four feet at the withers, are of a grey-fawn colour, with a black stripe down the eye, another down the gullet going down the under part of the neck, black cannon bones, black marks above the knees, and, lastly, a black stripe separating the colour of the back from the white belly.

Both sexes carry horns, the female having as long horns as the male, if not longer. The horns grow in the same plane as the face, curving very slightly backwards and regularly divergent. They are ringed at the base fairly heavily in the male, with the last eighteen inches at the point smooth.

In this country I saw one with a single horn on Laikipia, in very thick bush, and caught a glimpse of another as he crashed off, whilst I was creeping about doubled up.

This was on the banks of the Guaso Narok, and I cannot account for those two being in the 


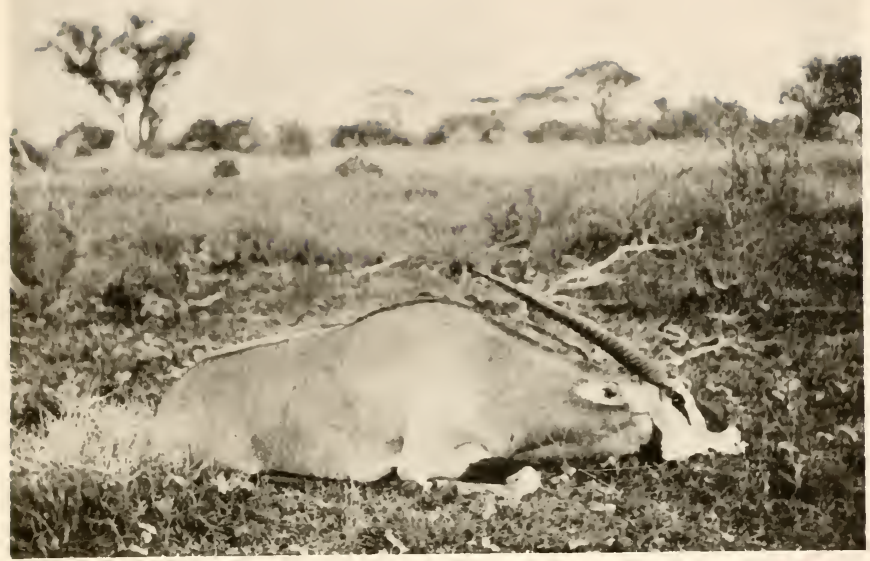

THE ORYX BEISA

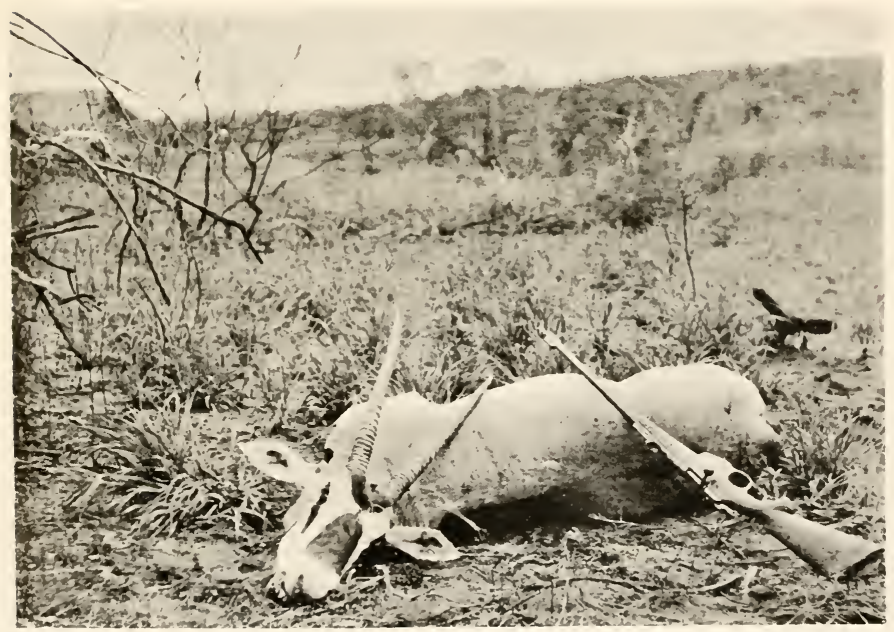

ORYX BEISA

NOTE THE EYE STRIPE A.ND THE ABSENCE OF HAIR ON THE EARS 



\section{Beisa Oryx}

desperately thick bush they were in, as they frequent open plains and wander in innumerable herds on the Guaso Nyiro in the north, whilst they are found at Lake Baringo and northwards to Lake Rudolph.

They are, or used to be, seen round the Pesi Swamp; but I have only seen their tracks there.

Round the Guaso Nyiro it was not hard to get at them in herds of ten to twenty and forty; but at the time of year I was there the grass was all burnt up by the sun, and the animal was really a very bad target, as the background was the same colour as itself, and judging distance was extremely hard in consequence.

They inhabit flattish and undulating plains with no cover to speak of, and do not seem to care about a drink. That applies more so, if anything, to them in Somaliland.

I was only lucky enough to bag one on the Guaso Nyiro, simply and solely on account of the nature of the ground. One's shooting goes off on occasions certainly; but mine was all right then, judging by other animals I secured at the same time; but hit the beisa I couldn't!

The oryx is possessed of great vitality, and will go on and on if not badly hit. They are rather ungainly animals to look at, with their highish withers.

I think one can rather take liberties with them in stalking in this country, though in Somaliland 


\section{Big Game Shooting}

they are as wild as hawks. They stare at one seemingly stupidly for a time, but they have got all their wits about them, and long before you have taken them in thoroughly, they are off at a gallop, whisking their tails, and, what is more, they then disappear, and there is seldom the chance of a second shot. Beware of taking on a bull mixed up with zebra. He will lead you a nice dance, and then you won't get him.

I have shot them in Somaliland, where the horns run bigger than in East Africa; but at the right time of the year, when the rains have made the grass grow down the Guaso Nyiro, they are to be found there in their hundreds.

I was there in November and saw a quantity, so what must they be like when there is plenty of pasture?

In Somaliland the Midgans (hunter class) pursue them with dogs. The skin on the withers is a good inch thick, and is greatly prized by them for shields.

They are striking-looking beasts. It is very hard indeed to pick the best head out of the forest of horns that show up in the herd. A single oryx will be a bull, and usually one worth shooting.

If badly wounded, they will stand at bay with tails to a bush, and, on one's getting close, will lunge out with their long pointed horns in a very nasty way.

An average head would be thirty-four inches. 


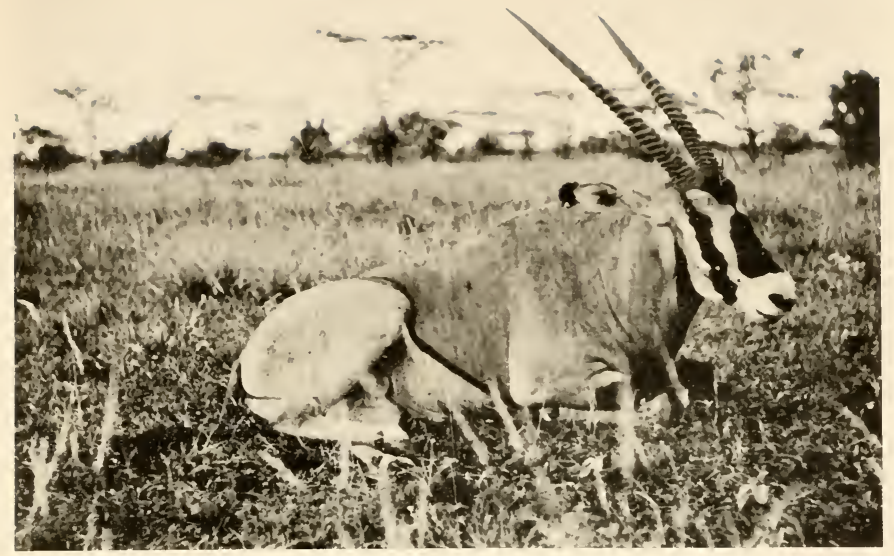

THE FRINGE-EARED ORYX

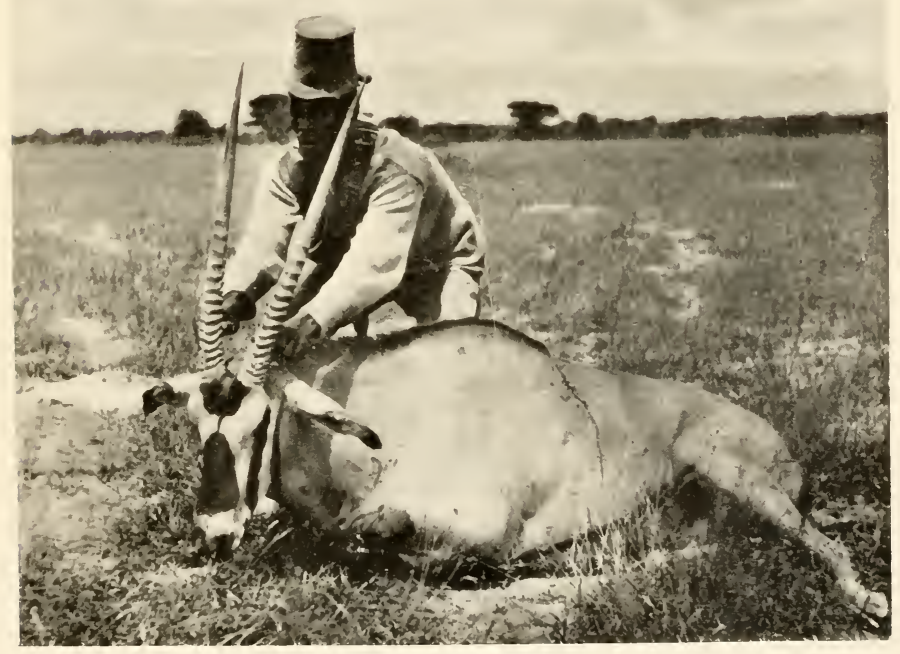

FRINGE-EARED ORYX 



\section{FRINGE-EARED ORYX ORYX CALLOTIS}

Swahili : Cheroa. Masai : Ngimosorrok

I

HAVE lately come across this animal on frequent occasions on the German boundary. As a matter of fact, he is of exactly the same shape as the beisa oryx, but smaller in build, and does not stand so high by a hand. The face markings also differ, the eyestripe coming right down to the bottom of the jaw ; and in this and the tufted ears lies the chief distinction between the two kinds. He is a greyish fawn colour with a black stripe down his back from the withers to the tail, which is also black; has a black line at the junction, on the flanks, of his fawn back and white belly, black splotches above both knees, the black eye-stripe extending broadly to the black line under his lower jaw, and, lastly, the tips of his ears are tufted as above mentioned.

They are found singly and in herds of four to even ten and sometimes twenty, and I recently came across a herd of forty-eight under Kilimanjaro, which, however, I look upon as being quite unusual. 


\section{Big Game Shooting}

They are very wary and want a lot more care in the stalking than the beisa oryx in this part of the world, but are, in my opinion, never such a bad target, as they chiefly inhabit green bush country. They are also, of course, to be found in stony country, almost bare, where they are extremely hard to get up to. One cannot take the same liberties with them in the matter of stalking as with the beisa oryx in this country. They have a way of looking apparently aimlessly in one's direction when one first sees them-say four hundred yards away-but that simply means that they have spotted one long before.

Their horns are of the same shape as those of the beisa oryx, but shorter. They are, like the beisa, possessed of great vitality, and will stand at bay in the same way; in fact, their habits are practically the same.

They astonish me a little bit in a way, being of course only a close offshoot from their ally the beisa, because, as well as liking dry, waterless, stony plains, they do not seem to mind wet ground and bush country. I was surprised to meet them, for instance, round Lake Nyeri under Kilimanjaro, a soda lake, and with marshes and big swamps all round; but there they were in quantities, apparently liking the wet. It was so different from the country on Laikipia and in Somaliland, which two localities resemble one another to an extraordinary degree. 


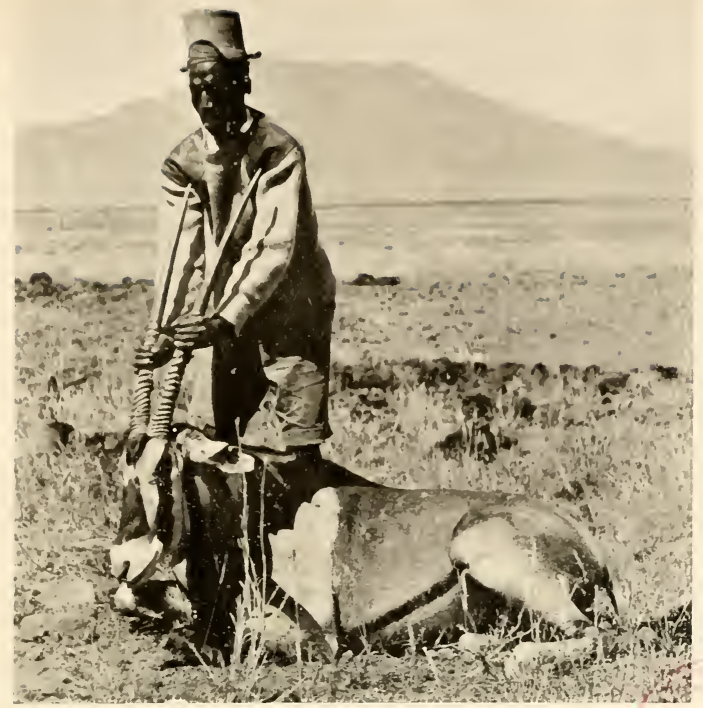

FRINGE-EARED ORYX

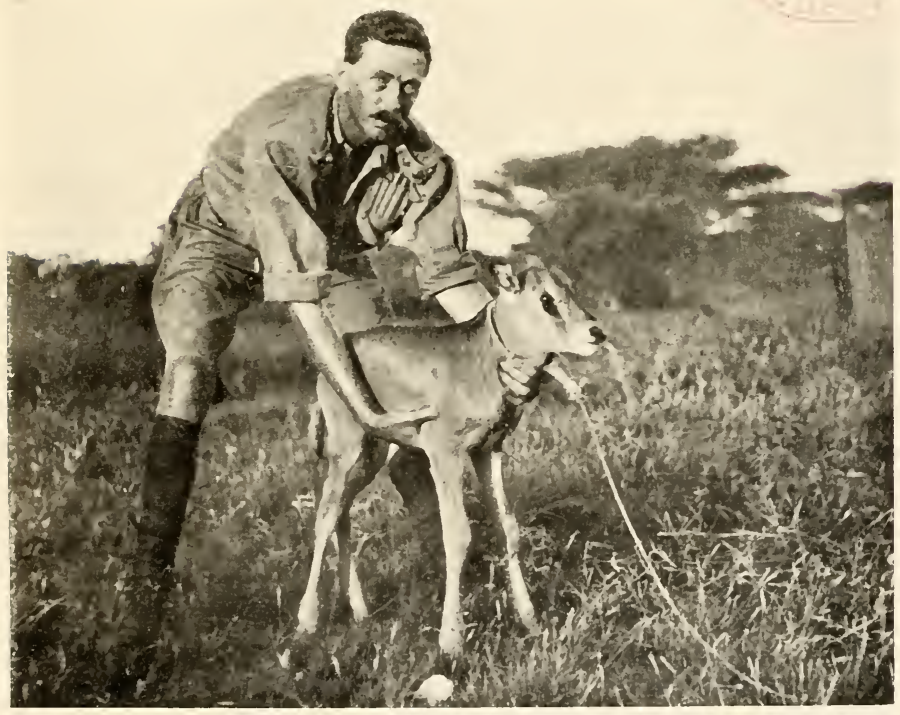

A BABY ORYX CALLOTIS 


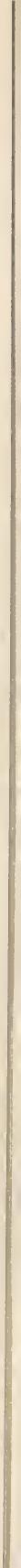




\section{Fringe-Eared Oryx}

Another point is that the beisa does not necessarily drink water, like his ally the gemsbok of the Kalahari Desert in the south, but the callotis does, and rather likes it. They used to water regularly every day in a hurried way, and get straight back again to their grazing ground at once.

They are found from as far south as the Taru Desert to Kilimanjaro, and thence north to lakes Natron and Magardie, and I saw a single one in the Reserve under the Ngong Hills on the edge of the Rift Valley near Nairobi.

I should say they are not found north of Mount Suswa, an extinct volcano in the Rift Valley.

Twenty-nine inches would be a fair head. 


\section{BUFFALO \\ BOS CAFFER}

Swahili: M'bogo. Masai : Ol-laro and Ol-osōwan

7 HIS is an animal which I must approach, as regards its habits, with great diffidence, as this is only my own small experience, and other people may know so much more about them. It is true I have had the most exciting morning of my life with them, as I shall show in a sketch at the end of this, and that is, to all intents and purposes, one of very few encounters compared with the chances I have had of observing the habits of other game animals.

The buffalo stands about fifteen hands high, and has a thickish black skin covered sparsely with black hairs. His legs are very short indeed compared with his height, so that his bulk is enormous. The skin under the neck is abnormally thick, on account, I suppose, of the fact that he has to make his way through the thickest of thick bush, which he does with his head up. When he charges, on the other hand, his head goes down, and the enormous horny bosses on 


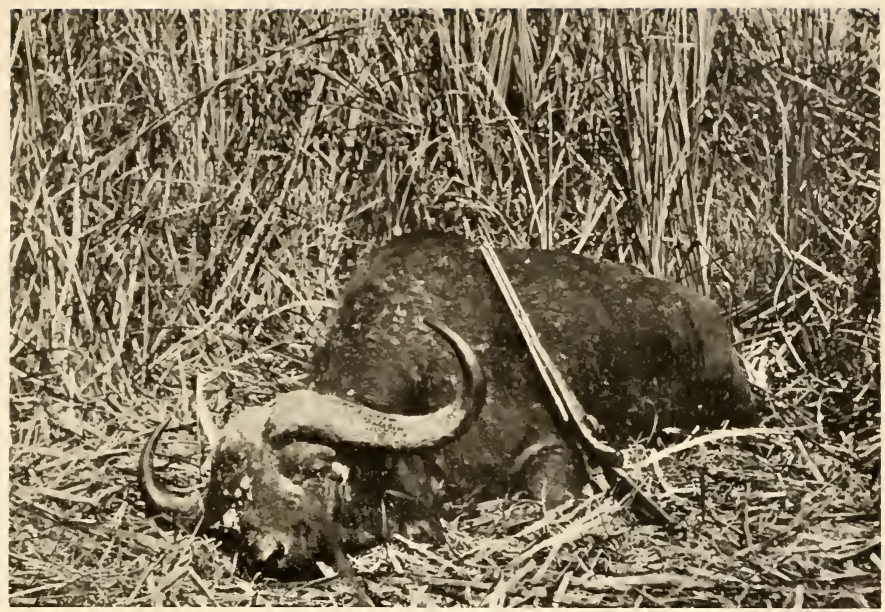

BUFFALO

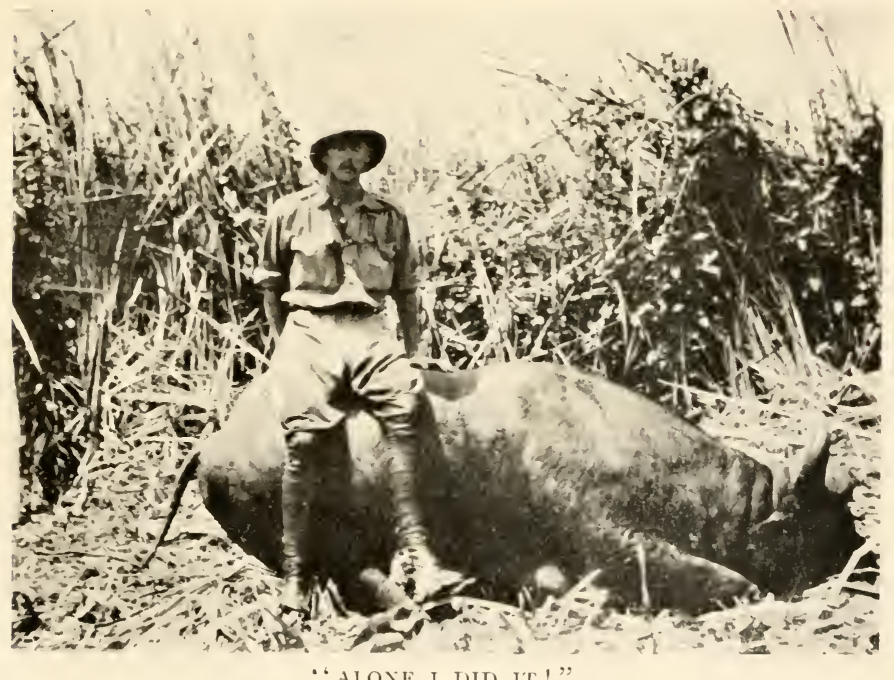




\section{Buffalo}

his forehead, separated by only an inch or so, afford a complete protection to the vulnerable parts, his neck and chest.

Of all animals in the jungle, he possesses far and away the best sense of hearing. To my own knowledge he will stand for two mortal hours absolutely motionless, quietly listening. His eyesight is also developed to a remarkable degree. Both sexes carry horns, but those of the cow are, as usual, thinner and smaller than those of the bull.

He appears to be going quite slowly, even through thick reeds and scrub, but in reality he is travelling to some purpose.

Buffalo are found in the most awful places, as a rule, that I have ever struck in any jungle. The first time I came across them was when a herd was concealed in twelve-foot scrub, high up on the side of a mountain. There were eight or ten Masai warriors to help me find them in the gullies on the hill-side, and all of a sudden I found myself in the thick, literally, of a snorting he $d$ of twelve or fourteen, charging and crashing promiscuously about. To add to the confusion, an ancient and very crusty old cow rhino, with a calf, turned up. I was in terror of my life, and all I saw was a black object for an instant, but too quickly to make out if it was a Masai or a buffalo. It struck me as being lucky to get out of it. 


\section{Big Game Shooting}

Since then, in much the same swampy, marshy country as is depicted in the sketch hereafter, I have been mixed up in small herds, biggish herds, and two or three at a time. Often whilst walking along in buffalo country one would "get up" with a rush and a snort from the opposite side of the very bush I was creeping round on all fours.

The sum total of it all is, that when unwounded an African buffalo runs away as an almost certain rule. If he is hit anywhere whilst running away, beware! He goes on, and retracing his steps parallel to his path, lies up within two or three yards of his former tracks. His idea is-and a very good one too-that the sportsman with the rifle has him on toast in ordinary country. $\mathrm{He}$ therefore disappears hurriedly to what he knows is the country that suits him-in other words, swamp with plenty of clinging mud and a bit of water, and reeds fifteen to twenty feet high - so that he can meet his pursuer on even terms. If you follow him you can see nothing one short yard on either side, whereas with his sense of smell, to say nothing of sound, you are charged before you can say knife. If he is hit charging and not knocked down, he may come on and will do a little hunting of the hunter, but a second bullet in a nasty place may turn him. The buffalo has the most extraordinary vitality.

They feed and water at night, and wander in 


\section{Buffalo}

thick swamps casually, or lie up in thick dusty dry scrub by day. They have finished watering and feeding long before five o'clock in the morning, as a rule. Of course every animal does odd things now and again. A friend recently saw one standing under a bush out in the open, and had a bang at it, making sure that only a rhinoceros would be out in the burning sun at Ioa.m. He was fiercely charged for his temerity, but managed to slay the brute all right.

I was run at in thick bush by two on another occasion, but they had to stop to listen for me, as I happened to be the right way of the wind. Master never took such pains in his life to get out of the way.

I may say it is little short of madness to crawl on one's hands and knees up one of their pathssome two-and-a-half feet high by two feet widein their pursuit. Both sides are impenetrable, and one deserves to be soundly kicked for doing so. I might almost put that under my "Don't" headings. It would be very difficult indeed to shoot at all, considering that, firstly, one is quite blown in the first hundred yards, and the sweat is pouring into one's eyes with the exertion of making one's way along in an unnatural position ; and secondly, it is quite dark enough without having a crashing and snorting brute charging down to worry one, besides making the passage forty thousand times darker than it usually is. 


\section{Big Game Shooting}

However, every one does it till they find out for themselves what it is like.

Buffalo are found all down the German boundary, particularly near Lake Natron, on the Ngong Hills behind Nairobi, on the Tana River, on both the North and South Guaso Nyiro rivers, and near lakes Solai and Baringo, where there is plenty of thick bush with a bit of swamp. A good head would tape forty-five inches, but the bosses should be well crinkled and broad. 


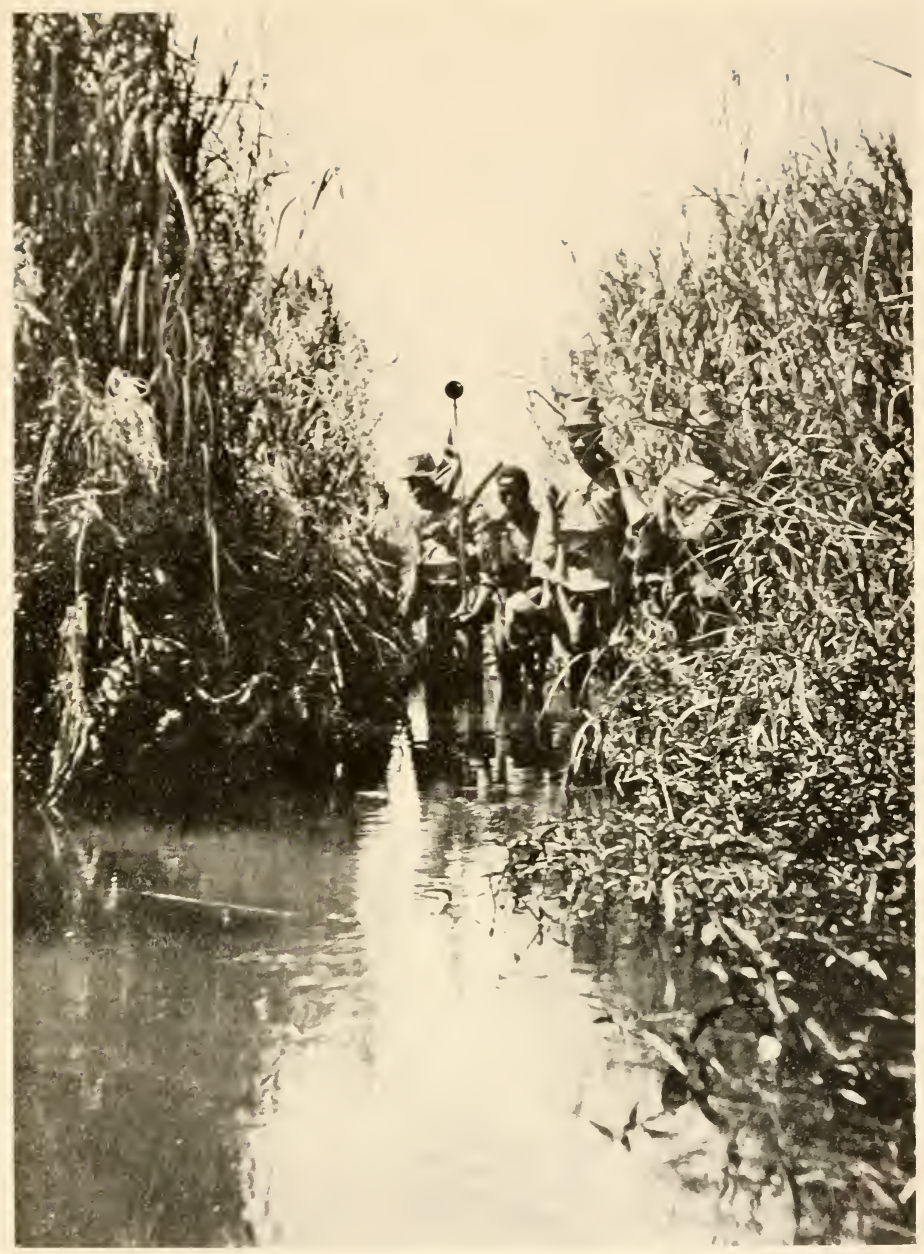

THE RNTฬANCE TO THE SIVAMP 



\section{A BUFFALO DRIVE}

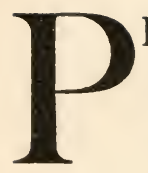

ICTURE to yourself a huge swamp, some ten miles long by three across, of reeds fifteen to eighteen feet high, and underfoot a boggy slush over one's ankles. It is early dawn, and the mosquitoes, that will soon be dispersed by a brazen sun, are biting and sucking for dear life, as it is not often they meet a confiding man to feed off in this part of the globe, and him white into the bargain. Dead silence prevailed everywhere except for the brass band provided by the mosquitoes playing all round us.

Some time previously we, my friend Wilson and I, had come to this very place in pursuit of game and had put up a herd of buffalo, but could not get in a shot owing to the impenetrable character of the undergrowth. Since that we had on frequent occasions tried again, but always with the same want of luck, so eventually we decided to build ourselves perches-a thatch of sticks and grass raised some eighteen feet high on stout uprights sunk in the ground, and firmly lashed with cross-pieces to withstand a considerable shock. We had built them on the edge of 


\section{Big Game Shooting}

the swamp referred to, where the grass was moderately short, between it and a patch of very dense scrub jungle, which the buffalo frequented to lie and sleep in, to pass the heat of the day.

Our plan was to creep round by a detour cautiously to these thrones, and then beaters, who were timed to start an hour after us, were to come out and fire a few shots into the air, and so to stampede the herd towards the swamp on to us lying in wait for them.

Of course, if a buffalo had hit a perch in his flight into their sanctuary it would most certainly have collapsed, and the unfortunate sportsman would have been in a bad quandary. As it happened, the whole idea could not possibly have proved a greater success if one had spent a year of thought over it-from the point of view of driving the buffalo out; but of course the shooting might, and certainly ought to, have been straighter. They came out like the best-driven partridges, and I can never hope for better.

On the appointed morning, Wilson and I started off to our perches, hoping that time enough had elapsed to have driven away the smell of the men who had been cutting the wood and moving about, and allowed the buffalo to come back to their lying-up places for the day.

I and my Masai orderly, Wilson and his Somali gun-bearer, on nearing the perches, put up about five of the animals, which charged off 


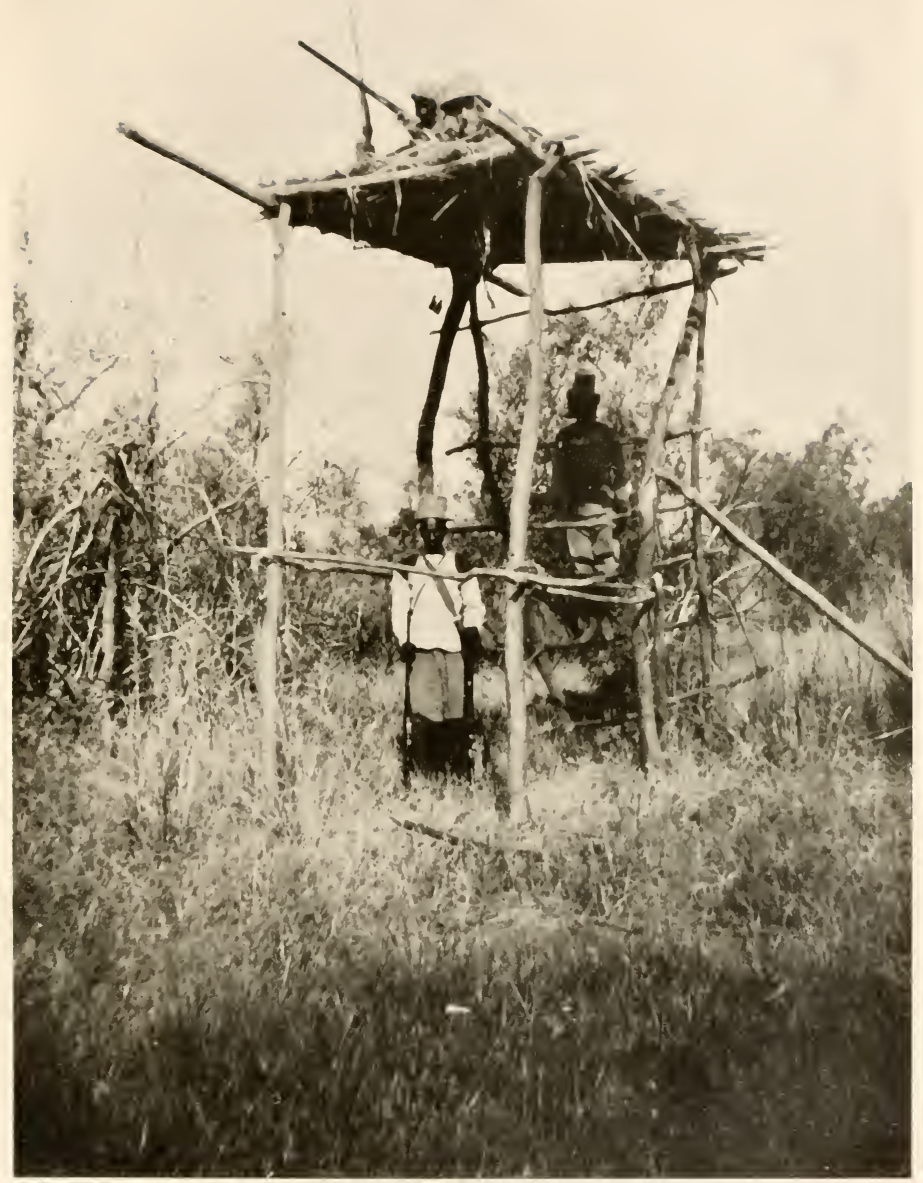

ONE OF THE PERCHES WE BUHT FOR THE BUFFALO DRIVE 



\section{A Buffalo Drive}

into the thick stuff in the wrong direction. We thought all was over and felt correspondingly sick at the thought, as we made quite certain that they would give the alarm and that everything would leave the bush as well.

However, I lit a cigarette and tried to put the best face on matters, as the mosquitoes had redoubled their efforts, when suddenly, before the beaters, who were due to arrive at $6.30 \mathrm{a} . \mathrm{m}$., had turned up, there was a scrimmage in a bush thirty yards from me. It seemed as if that bush had gone off its head without any warning, as it began to crash and sway about, where before was perfect peace and quiet.

Five buffalo charged out towards the reeds in the swamp. Like a fool, I had a shot at the first that appeared, which happened to be a small one, as I thought this was absolutely bound to be the first and last chance we should have that morning. I managed to knock him down, but he went on. At that moment (I had opened my rifle to put in a fresh cartridge) a large bull dashed past my perch ten yards away; but the beastly rifle jammed. I cursed volubly, and my orderly, who evidently thought I was slanging him, nearly fell off the perch in his agitation, as I was leaning on and over him. However, I got in two shots when the beast was twenty-five and forty yards away, the first smashing his foreleg, and the second flooring him. 


\section{Big Game Shooting}

This was most satisfactory work, as he was a very nice bull indeed, with a great spread of horn; besides which it was very early in the day, and I had begun well, and so was much pleased. I thought I would wait for a moment for the end of the drive, and in case anything else broke cover from close by-and as it turned out it was a most lucky thing that I did not kill him under the perch, as I should have been down ten minutes later admiring and measuring the brute-when sure enough six more rolled out from the same bushes.

It was a most extraordinary thing, as the banging of a 400 cordite makes a fearful row, and I had had five shots - all getting home, as I found later. Whether they tried to mystify us by coming out unexpectedly and in small parties I don't know, but they certainly executed a masterly retirement, only, unfortunately for them, they were badly mauled in so doing.

Well, one of this second batch retreated into the swamp with three bullets in him. I wanted to make certain of another and try and kill him in full view; and so I suppose I was far too excited to take real good aim, and, in fact, lost my head a bit.

Then I made up my mind that that was absolutely the last we should set eyes on, but luckily again sat tight, till ten minutes later three came back out of the swamp across a tongue of grass, 


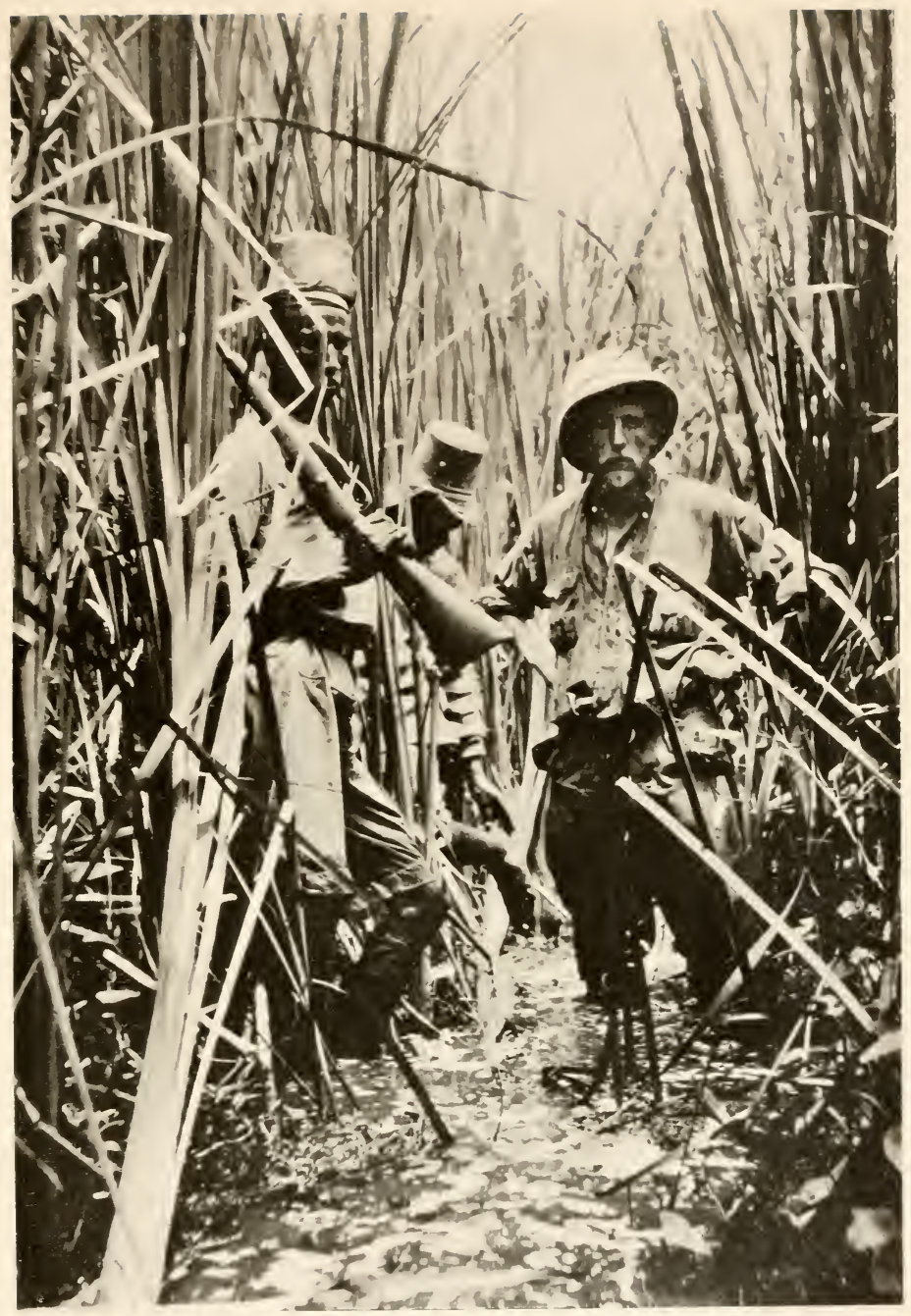

INTO THE SWAMP AFTER A WOUNDEI BUFFALO 
. 


\section{A Buffalo Drive}

giving me a hard shot. It must have been the last lot, who had been lying up, hoping and praying that some misguided being would pursue them into their own stronghold. Their part of the game is, on being hit, to disappear down one of their paths-boggy underfoot, with a dense mass of impenetrable reeds on each side-and after a short distance to turn on their tracks for some way parallel to their former path, and stand motionless about three yards away from it, waiting for the most cautious footsteps, and then have a sudden dive at their pursuer. They are most wonderful brutes for their sense of hearing, and will stand without twitching an ear for hours if they think they can play their little game, and attack on ground of their own choosing. The worst of the thing is that when they succeed in getting their charge anything like home, their heads being down and the tremendous horny bosses protecting their brain and their wide sweeping horns their chest, nearly all their vulnerable parts are automatically armour-plated. A softnosed bullet from a heavy cordite rifle will do the trick in the right place, which is between the bosses, and will kill the brute, or, if it misses the brain, knocks him down with a bad head to boot and turns him; but their vitality will take them a long way, and they are just as nasty after being knocked down twice as at their first straight-away charge. 


\section{Big Game Shooting}

However, to continue. Up to this, Wilson had had the misfortune of not having had a shot, but of looking on from three hundred yards away at what he thought (so he told me afterwards) was my firing wildly at bushes and grass moving.

The next thing that happened was the beaters beginning to loose off outside the bush, and at once a huge bull dashed out, giving Wilson a chance shot at i 80 yards or so. He came past me about forty yards away, and I distinctly heard the right and left tell somewhere. The idiot, as I thought him, stood after that a little further on behind a thin tree, and I got one more shot in, when down he flopped. I patted myself on the back, and the orderly said "splendid," or I translated it as that!

After that more came out and went across me, and I got another two shots in, which told. But I'm afraid the recipients went on.

Soon after, I saw Wilson's gun-bearer playing about between our perches. I must here say in explanation that when the fourth lot came down on me I had a shot with a solid Mannlicher, and at the same time I heard Wilson's '450 cordite tell loudly on the animal. One of that lot came towards me grunting in pain-Wilson's of courseand the lot shot into a strip of bush between us. Five went in, and four came out. That is in parenthesis. The beaters began firing odd shots again, and there was a tremendous stampede in 


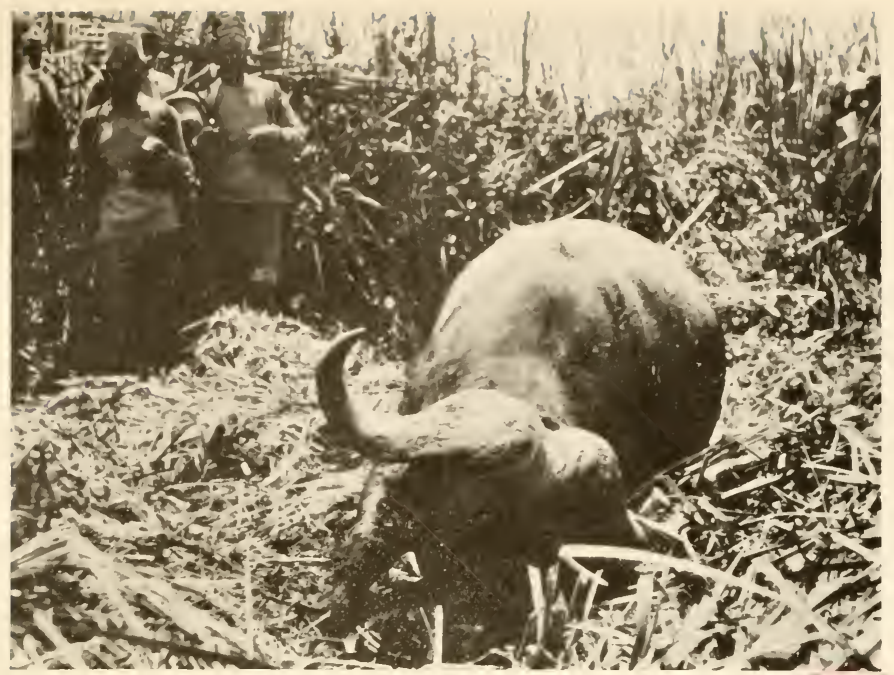

A FINE OLI BULL BUFFAI.O

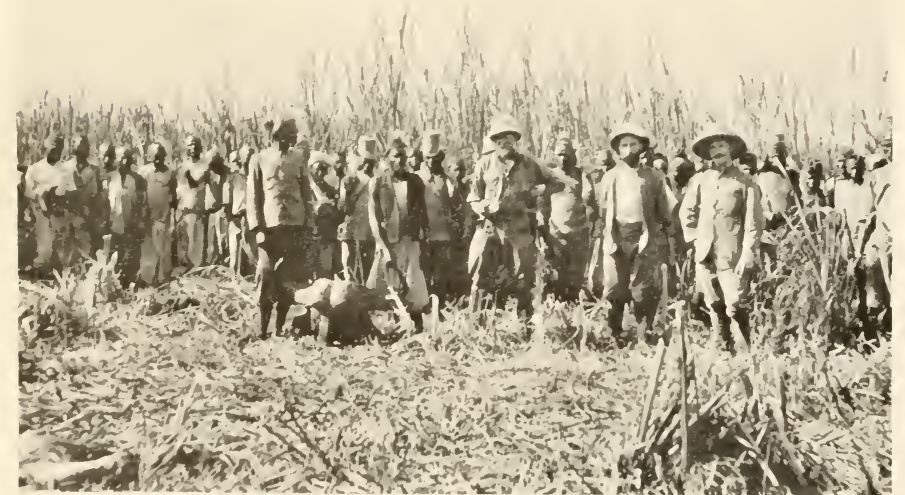

THE END OF THE BUFFALO IIUNT 



\section{A Buffalo Drive}

front. There must have been forty or fifty more sitting quite tight in their places whilst the fusillade before described was going on. We never saw this last crush, but Wilson's orderly ran back to his master's perch in a hurry. In a short time I saw him advancing with a Mauser, quite casually, to me again. He came and delivered his message, and talked for a few moments, and returned, stopping on the way to do a bit of prowling about "on his own." He was a short distance from me, still messing about, when all of a sudden there was a crash and a cloud of dust, and a buffalo charged out at him from quite close, and I saw him hoisted up on the brute's horns, very slowly, which I couldn't understand at the time. He slid off its back, and then the buffalo turned round and, as I thought, gored him with her horns when he was on the ground. I imagined it was all over with him. It was a beastly sight. The buffalo then disappeared again where it had come from, and to my great relief I saw the man stagger up and walk off. I shouted to Wilson, "The man is up." As there was a tall bush between him and the scene of the occurrence, and beyond, a snorting and a cloud of dust, he had only been imagining things.

Then we talked or rather shouted to one another, still on board our perches, and then finale!

On comparing matters on our way home, I had 


\section{Big Game Shooting}

two buffalo and Wilson one, which was a splendid cow which he had got in the neck. As his orderly, who, I may add, had escaped quite unhurt except for a severe shaking, said, the blood on him was the buffalo's, as if she had not been very badly wounded, "he would have been dead."

This agrees with what I saw when she tried to toss him; that it was not a toss, but a great muscular effort of the neck of a very far-gone beast.

It would have been madness to follow into the swamp five buffalo, wounded and angry, to say nothing of their friends and relations who were also horribly annoyed at our impertinence in worrying them, so we left them for next day, and went home, having had, from my point of view, the best morning's sport, bar none, in Africa, I have ever hoped to see, and expecting that the vultures, or later perhaps the hyenas, and the smell, would lead us to them, which proved to be the case. 


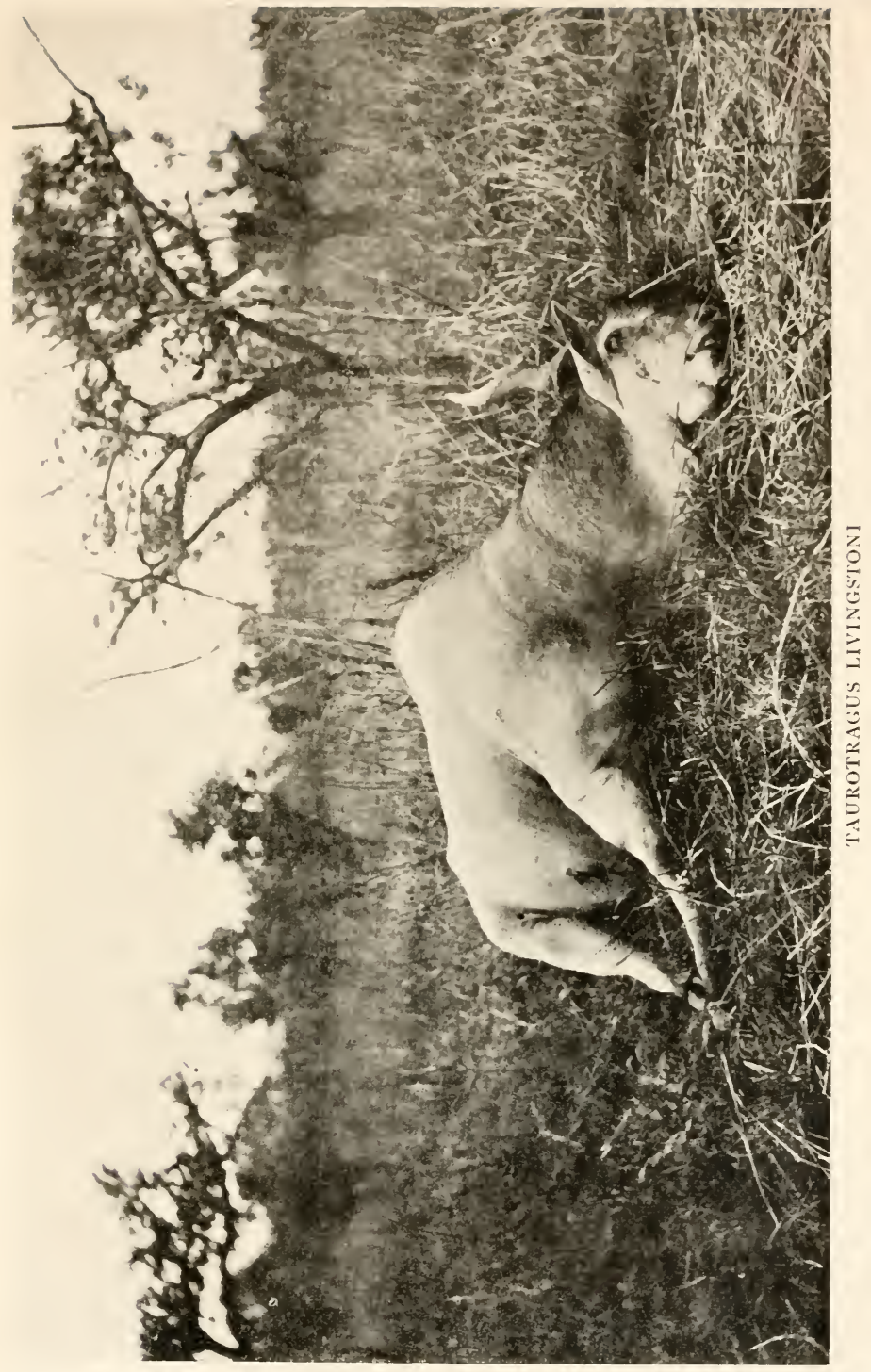





\section{ELAND}

TAUROTRAGUS LIVINGSTONI

Swahili : Pofu. Masai : O-sirua

$7 \mathrm{HE}$ eland is the largest of all antelopes to be met with on this continent. A bull stands very near eighteen hands at the withers, and is a fine imposinglooking animal to meet.

In shape they are a mixture between the antelope of commerce and Devon cattle, the bull having a hump on his withers and an enormous dewlap. It is Livingstone's eland that is found up here in the north, and this is distinguished from the Cape species by its darker colour, chestnut-fawn, with a brownish knee-mark and vertical thin white lines from the spine, rather more marked in the bull than in the female. The bull has a big tuft of hair on his forehead. The cow is of a rather lighter shade in colour. Both sexes carry horns, shorter and thicker in the bull than in the cow, in which sex they are, as usual, long and thinnish. The horns are straight, screw-shaped, and slightly divergent, leaning backwards all the way. 


\section{Big Game Shooting}

Eland are found in herds of from five or six to twenty, and sometimes fifty and sixty. The bull (there is, as a rule, only one big one to the herd) invariably comes last.

I cannot help thinking that the eland is quite the most difficult animal in the jungle to get near. It may be my stupidity in stalking, but I have come across lots of herds, and up to date I hold that opinion. Anyhow, if a sportsman does a really careful stalk, I hope Luck will befriend hirn better than she has me. The first eland that I killed was a cow, I am sorry to have to relate, and that was also through my stupidity. I had done a most painstaking stalk to within sixty yards, and thought that at last my patience was going to be rewarded. However, something startled them, and the bull and an unfortunate cow got mixed up behind a bush; at any rate they came out wrong way on, and in the rush I bagged the cow with one shot. I found that one 256 Dum-dum bullet was sufficient to lay her out on the spot. I mention this, as lots of people tell me that they are as a rule very difficult animals to stop.

I have before and since pursued them violently in bush, grass, and on a fairly open plain, but I suppose I am fated not to get a real big bull, or anywhere quite near a herd.

On going down to water, the cows and calves come first, and very often pretend to be frightened 


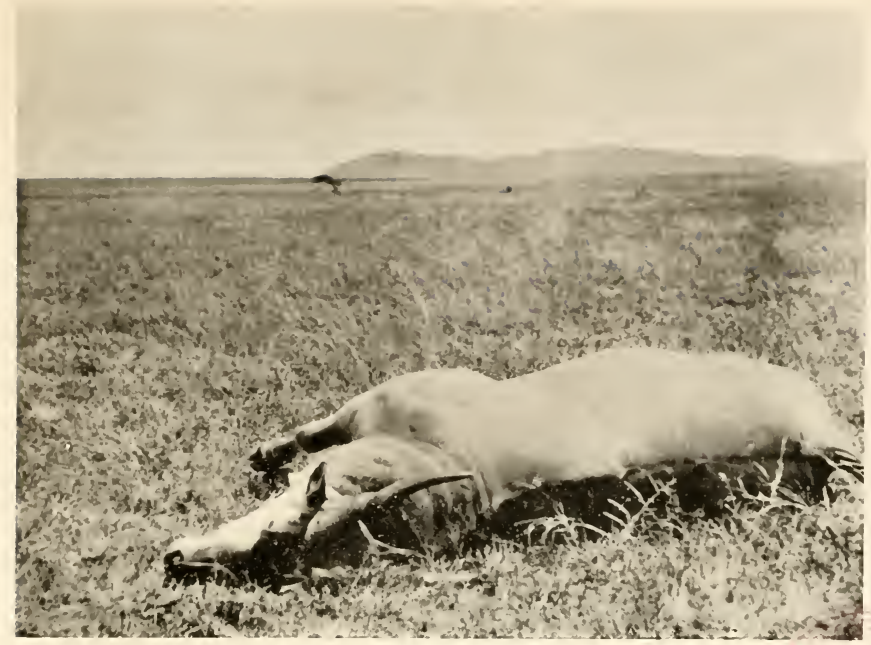

A BULL ELAND

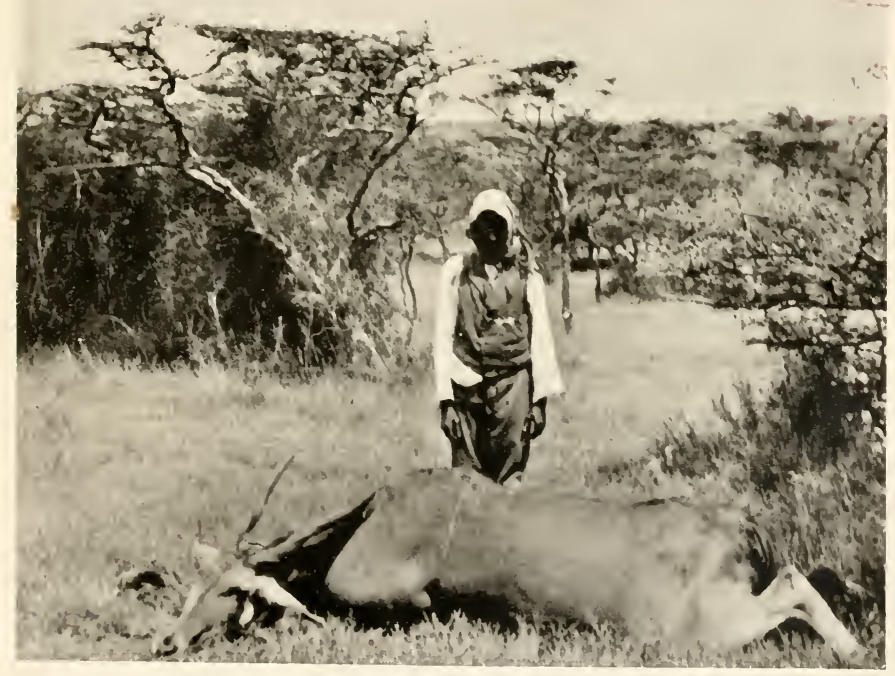

A COW ELAND 



\section{Eland}

and run for a short distance; they all return at once, and then the bull appears; they all drink for five minutes or so, and then walk off fairly fast, as if they distrusted everything. This last is from personal observation at different places for three or four days each, and so I think there is something in it.

They are "local" animals, provided they have not been frightened and have not seen one, or what is just as important to an eland's nerves, have not heard a gun go off. Otherwise one may hunt for them day after day, and never a one will be seen.

I have found them on Laikipia, but not in large numbers, and there are a few on the Athi Plains; round Kilimanjaro, Arusha, and Erok they are very plentiful; and further north on the German boundary in the Mara River district they simply swarm-so it appears as if they are recovering from having been decimated by the scourge of rinderpest of ten years back.

An average bull should measure thirty inches, straight. 


\section{ROAN ANTELOPE}

HIPPOTRAGUS EQUINUS

\section{Swahili : Nelgut. Masai : Lalgut}

7 HIS is an animal I do not pretend to know much about.

It is of a grizzled red roan colour, with a long mane and huge ears, and its face is marked in front, something like an oryx's, with a big black blob. Its annulated horns have a backward sweep, something like a water-buck's, but turned the wrong way, and regularly divergent, besides being more curved. A friend of mine mistook a roan for a water-buck once when the former was "on the list"! He only saw its head, I must admit. The females carry horns, but they are thinner. It is quite hard to distinguish between the two sexes in a herd from some distance away.

I have only met roan for ten days, and managed to secure a nice head. The animals being only found in certain districts makes it hard to describe "roan country," but it frequents grassy bush, and is quite partial to hills thrown in now and again. It likes a well-watered country, and 


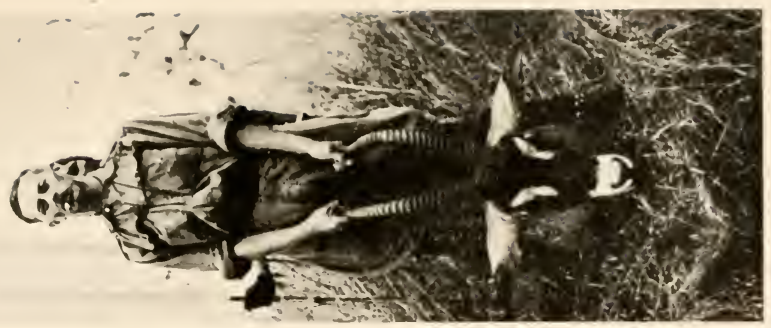

4

$=$

$\equiv$

.

논

50

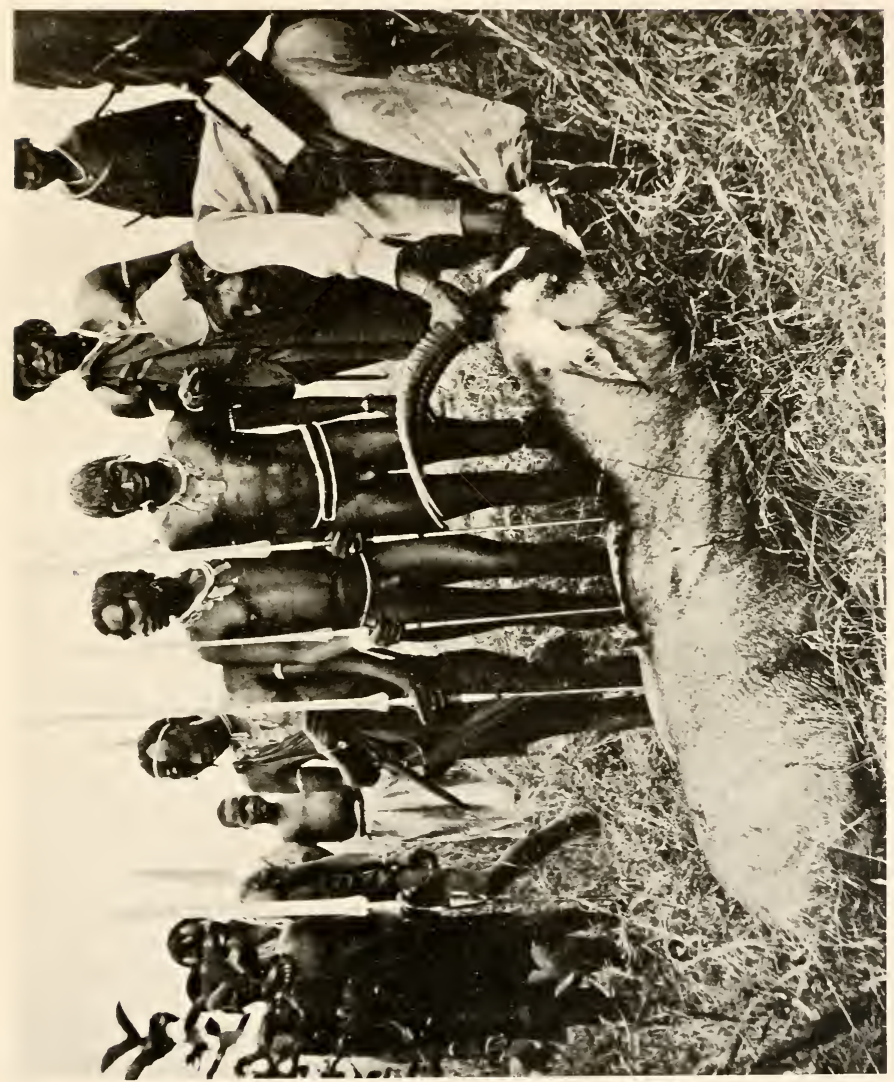





\section{Roan Antelope}

sometimes collects a stray Jackson's hartebeeste to help do "sentry go"; although roan are pretty cute by themselves.

I think they want a lot of stopping, and I fancy the consensus of opinion is that they must be hit in the right place "in once," or that otherwise they will go on.

They are met with in herds of from six to fifteen and thirty, and a single buck is usually pretty good, that is to say for East Africa, where the heads run smaller than they do further south.

I very much regret not having joined the Anglo-German Boundary Commission sooner than I did, as very large herds were met with nearer Lake Victoria than the part of the country I shot them in. I am told they were excessively common in the certain district on the boundary.

They are hard to get at, and take a deal of trouble in stalking. They are rather sought after in East Africa, as they have only recently been taken off "the list," and also they are so striking-looking set up on the wall. Perhaps this last fact makes them harder to get near, as when a sportsman hears of a herd in the vicinity he stays an extra day or two to get one if possible, and therefore their being shot over tends to make them shyer.

Properly set up with their masks the heads make a most handsome trophy. 


\section{Big Game Shooting}

Roan are found in certain places only, I think; in quantities on the German boundary near Lake Victoria on the Mara River; at Mohoroni on the Uganda railway; and I have heard of a herd or two behind Donyo Sabuk, north of the Athi plains.

An average head is twenty-eight inches. 


\section{IMPALAH \\ EPYCEROS MELAMPUS}

Swahili: Swallah. Masai : Ndarawet

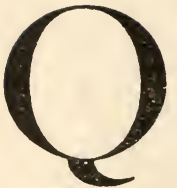

UITE the prettiest of the smaller antelopes it is possible to imagine, I think. Bright foxy red, with most beautiful spreading horns. One notices in this species, in common with a few other African antelopes, that when it is looking at one the inside of the ears seems all barred black and white, which adds greatly, in my opinion, to its beauty. It has two tufts of black hair on its hind legs just above the fetlock, which I fancy are altogether peculiar to the species. The females carry no horns.

On being alarmed, the herd very often cannot make head or tail of the strange object in front of them, and the females stamp and snort before they make off. Directly one moves hand or foot, and fires a shot, however, the whole herd goes off with a series of tremendous bounds, sometimes over bushes, but generally over nothing. This is another peculiarity of the impalah, and a very pretty and extraordinary sight 


\section{Big Game Shooting}

it is to see the whole herd simultaneously flying, so to speak, through the air.

They are usually found in herds of about fifteen to twenty.

It by no means follows that a solitary buck is a real big one-rather the contrary, I think. The big buck of the herd comes after the other bucks, and there are, as a rule, not more than two or three bucks to a herd. If herds of ten or more bucks are seen together without any female, they may be left alone, as one may be practically certain that there is not a "head" amongst them.

They will not be found at any distance from water; in fact, I have noticed that impalah and water-buck are the most regular drinkers in the jungle.

For instance, on the Tana River, after an early but short morning shoot, having had breakfast, we used to go to a high bank opposite a favourite drinking-place of all sorts of game, to where a screen of thin grass had been erected, to take photographs from behind. After we had found out their habits, we timed ourselves to be there roughly at IO.I 5 a.m. The impalah always arrived first, at 10.30 to 10.40 ; and immediately after they had cleared out, the water-buck turned up at 10.50 or so till I I.30, when they were all done. Both were punctual to ten minutes or so, if the wind was right and they had not been disturbed. 


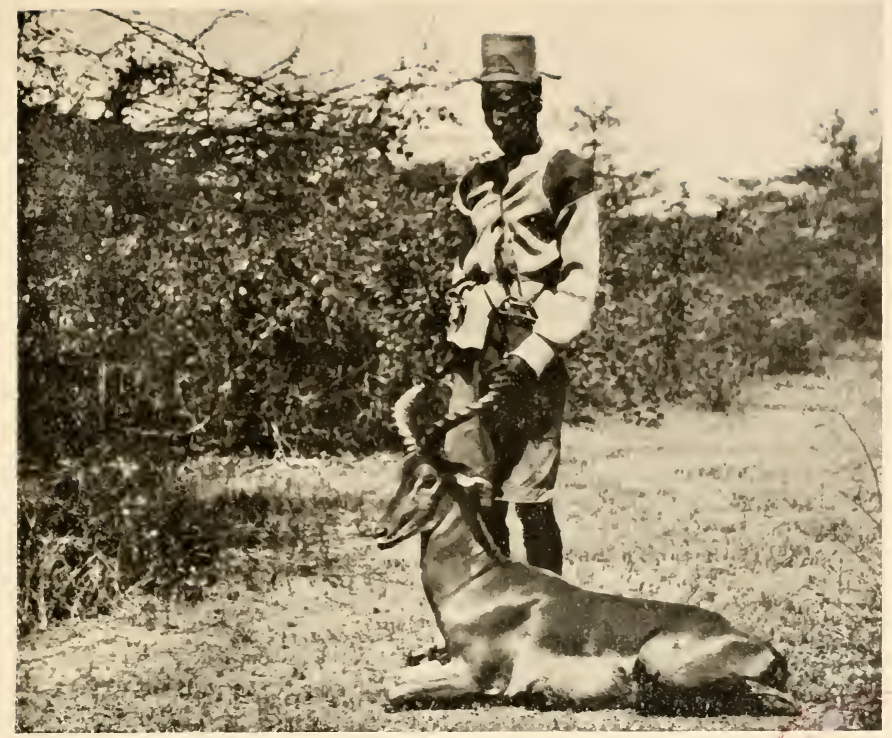

A. IMPALAH BUCK

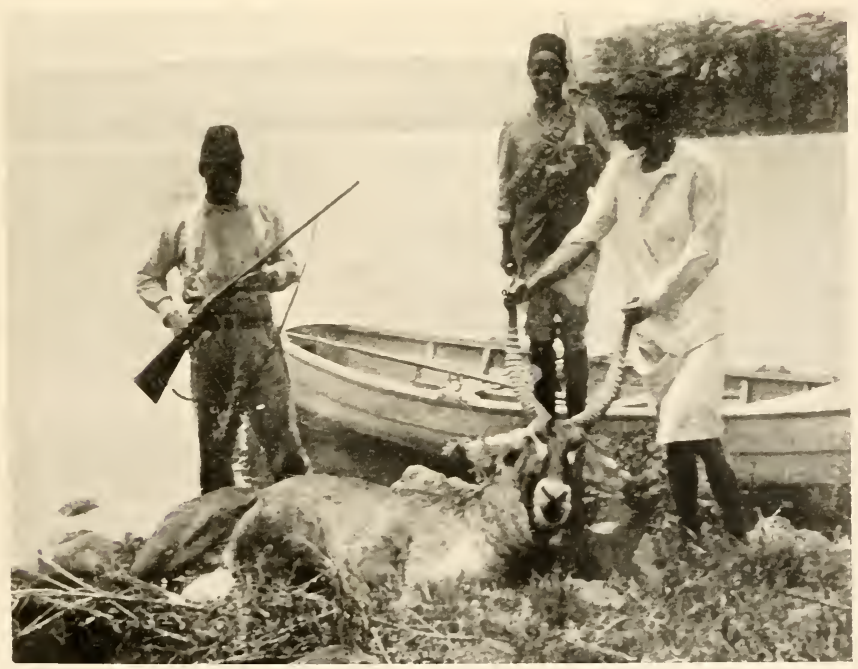

A WATER-BUCK ON LAKE NAIVASHA 



\section{Impalah}

I think the water-buck sent the impalah first, because the latter are better sentries, to see if the way was clear.

Again, at a certain camp on the Anglo-German Boundary Commission, where I stayed for a month, I had ample opportunity to verify this. Regularly every morning, down a certain path, I met the same herd of impalah at about 5.30 a.m. coming back from drinking. I met them so regularly because I never fired at them. Further along I always saw in the same place two herds of water-buck feeding away from water at about 5.50 or 6 a.m., and again, ten minutes after the latter, a splendid old water-buck, which I mentally marked down as mine every day, but could never fire at, as he was too close to the buffalo ground. I got him in the end.

The reader must please not think I have got mixed up with impalah and water-buck, but the fact of two species of game with quite different habits occurring together like this makes me wish to get that fact off my chest by taking the similarity together.

The impalah is what one may call a "local" beast.

This antelope has, in common with Grant's gazelle, one of the most deceptive heads I know, to decide about as to whether it is worth having or not. If his head, when seen "end on " as he looks at one, curves in very much at the tips, 


\section{Big Game Shooting}

leave him alone-he is not worth having. A good head is parallel at the tips, if not slightly divergent.

I fancy that a herd will be found hard to stalk, as they usually manage to see one first, and at once make off. They will probably be found to stop and graze slowly away a hundred yards further on, but as a matter of fact are thoroughly alarmed, and most likely are well on the move by that time. I should say the single buck is not quite so hard, as he has to find out everything for himself, and has no helping hand to aid him.

They are very widely distributed in East Africa, being found in suitable districts where there is water, from Laikipia to Kilimanjaro, and from Nakuru to the Tana River.

A good average head would be twenty-seven inches. 


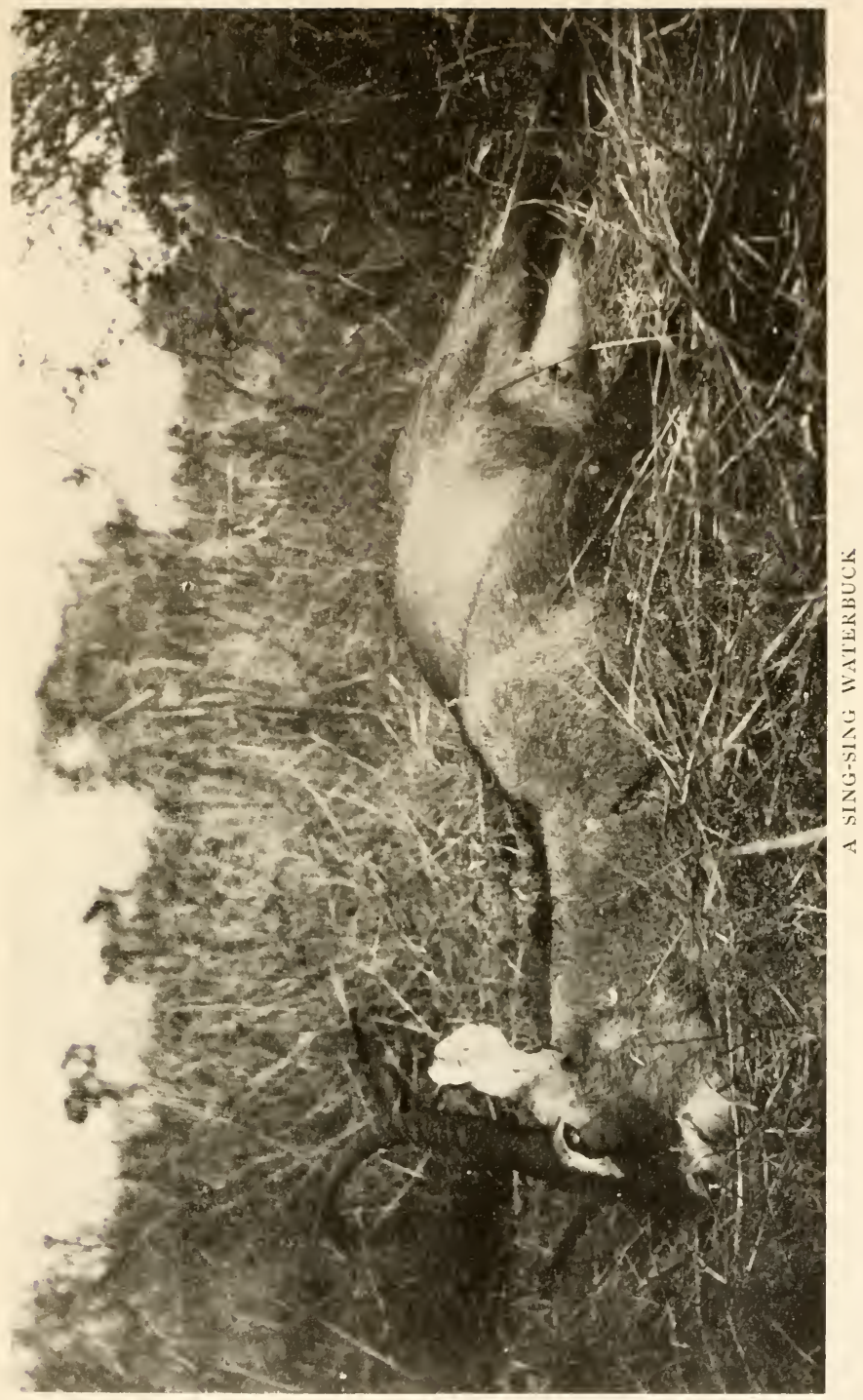





\section{WATER-BUCK}

\section{COBUS ELLIPSIPR YMNUS AND COBUS DEFASSA SING-SING}

Swahili: Kuru. Masai : Ol-kipulege

7 TERE are two well-known species of this handsome antelope in this part of the world-the sing-sing and the ellipsiprymnus; but after describing the difference between them, so that they may be distinguished at once, I may say the habits of one apply exactly to the habits of the other as far as I can make out, so they will be taken as one for that reason.

His rufous colour, with his long shaggy hair and the splendid backward, upward, and then forward sweeping horns, all combine to make this fine, upstanding animal look a gentleman, "from the word go." $\mathrm{He}$ is not unlike a Scotch red-deer, bar his horns.

The difference in the species lies in the presence of an elliptical white crescent on the buttocks, which extends downwards to the thighs, in the case of the ellipsiprymnus, whilst the sing-sing has a large white patch on the buttocks. Other- 


\section{Big Game Shooting}

wise there is no difference worth mentioning. Possibly the sing-sing is in some localities rather redder on the mask than its ally, but when the old bucks of each get grey with age, defend us from expressing an opinion! At the same time I doubt if the difference in colour is so marked in East Africa as all that.

They go about in herds of from three to fifteen and thirty, with one big buck and possibly one or two smaller bucks as well. The buck with two or three does only will probably be a good one, and so in all likelihood will be the solitary buck. If a herd of bucks by themselves is found, leave them alone; there will be no head worth having.

These and the impalah are the most regular of all animals in the jungle in their habits; but I have said all that under the heading Impalah.

As their name implies, they must have water quite handy. It is unusual to find water-buck in the vicinity of water in the middle of the day in East Africa, so don't trouble to look for them there then. Their times for watering vary : early in the morning in some districts, later in other places. I think that varies in relation to heat and cold.

The big buck of the herd is the last to approach water, but after they have all drunk he leads the way almost invariably to their lying-up place for the heat of the day. They usually go one or two miles away from water, grazing as they go, to the 


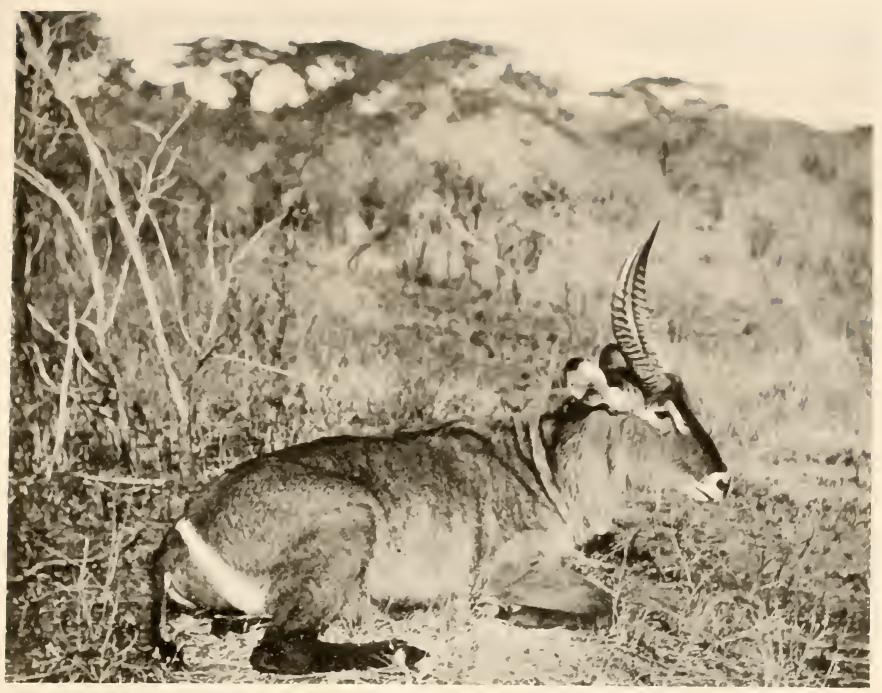

A SMALL ELLIPSIPRYMNUS

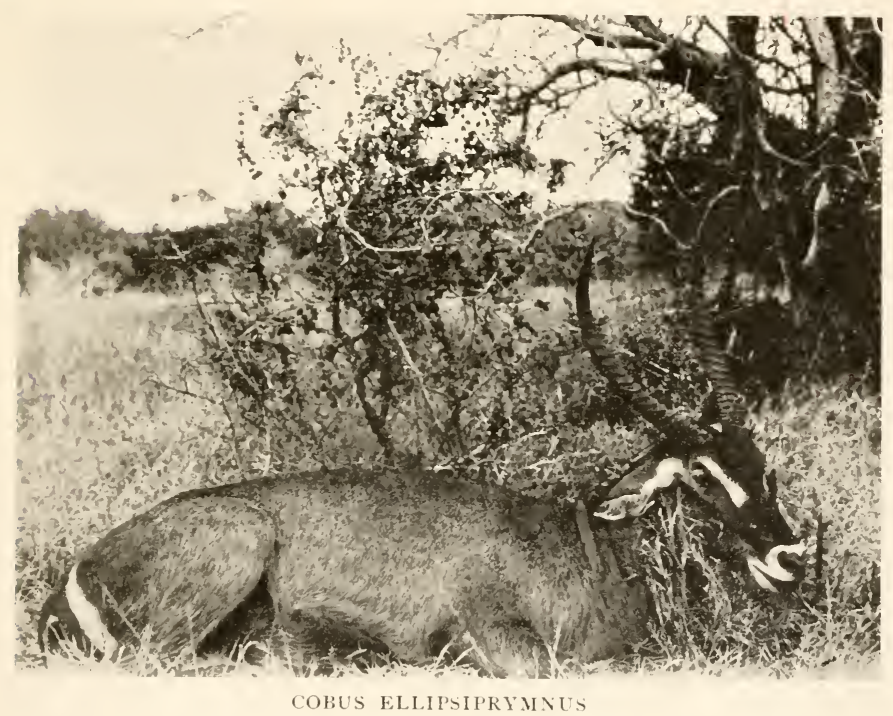





\section{Water-Buck}

friendly shade of some trees or thick bush. If you hunt for him there you must be careful, because, as like as not, he will have heard you first and will have left hurriedly! The water-buck is also a "local" animal.

I have heard them make such a noise when disturbed, crashing through bush and reeds, that I have mistaken them for buffalo.

They are not as hard to kill as most animals I have come across : that is to say, one bullet will almost always do the trick, where five in the same place will make no difference to the hartebeeste.

It will be seen in Mr. Rowland Ward's book, Records of Big Game, that in East Africa the sing-sing carries a bigger head than the ellipsiprymnus: that is to say, when one has been shooting each kind, the sing-sing will probably be found to have come out on top.

I got a most unusual one on Laikipia. Its horns were almost straight, and made an equilateral triangle with the tip to tip measurement. It is an ugly, although an enormous-looking head.

A water-buck, on catching sight of one, usually in bush or long grass of course, stands and stares for a few seconds. When he bounds off he will usually stop again within fifty yards to have another look. Be ready for that shot if you consider the head worth having. His head-the females do not carry horns-is a little bit deceptive, but not so hard to decide on as other animals. 


\section{Big Game Shooting}

I think that if the horns seem to spread outwards and then in at the tips, and at the same time the head looks big, it will be found to be a much bigger head than one that goes outward and then straight up. That is only my idea, but I have found that that rule answers to a certain extent.

They are to be found almost anywhere where there is water-on the Tana, on Laikipia, on the German boundary, on any river or lake in the Rift Valley; in fact, it would be hard to mention a biggish river that does not own its water-buck, either one kind or the other. On a certain very big swamp and its surroundings on the German boundary I found both kinds together, that is to say, each in their proper herds. I cannot explain that, but it makes me certain that their habits and likes and dislikes are the same. At the same time, I am equally sure that they were not crossbreds or hybrids, as I shot both kinds there to verify that and compared each with former notes.

Twenty-eight inches for either variety ought to be all right. 


\section{WILDEBEEST \\ CONNOCHETES ALBOJUBATUS}

Swahili: Nyumbu. Masai : O-engat.

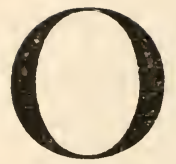

$\mathrm{F}$ the genus Gnu, the white-bearded species or wildebeest, as it is called locally, is the only kind that occurs in large quantities in East Africa; that is to say, having heard from one or two people that the white-tailed gnu has been seen by them, I won't take my oath about it. At any rate, the latter are protected and so are no use from a shooting point of view.

The gnu is in colour slaty-black, with darker brindle markings on its fore quarters and on the base of its neck. These are rather due, I think, besides its colouring, to the hair on these markings not lying down in the same way as on the rest of its body. The cow is marked in the same way. In certain lights in the sun, the animal has the appearance of looking quite a whitey-grey colour, and then seems to be a huge brute. The hair on the bridge of its nose is blacker than on the rest of its body. The tail has a black tuft on the end. It is in shape not unlike the North- 


\section{Big Game Shooting}

American buffalo as seen in pictures in boys' books, bar the shaggy skin and short horns.

Its horns spread outward from the boss, slightly downwards, then upwards and inwards towards one another, and backwards (rather like what a very small and thin Cape buffalo might be like). It has a black hog mane, a most distinct Roman nose, and a longish white beard extending from the gullet to the breast-bone, nearly.

When seen on an open plain two miles or more away by itself, it can easily be mistaken for a rhino, till one gets one's glasses to bear on it. Its bulk looks even then enormous for some unknown reason.

They are found on plains, as a rule, very sparsely covered with bushes (or absolutely bare, as on the Athi Plains) in herds of from twenty to fifty. Single bulls are very often seen standing right in the sun and without any cover. Such a one then looks more than half asleep, and exactly as if he had lost himself.

Sometimes the herd will disappear in a cloud of dust when one is on the horizon; at other times one may take great liberties with them. I think that depends entirely on whether they have been shot over much, which is by no means the reason for other kinds of game bolting.

They must drink every day, and seem to hang about over the water for two or three hours at a stretch, always with a sentry, however. 


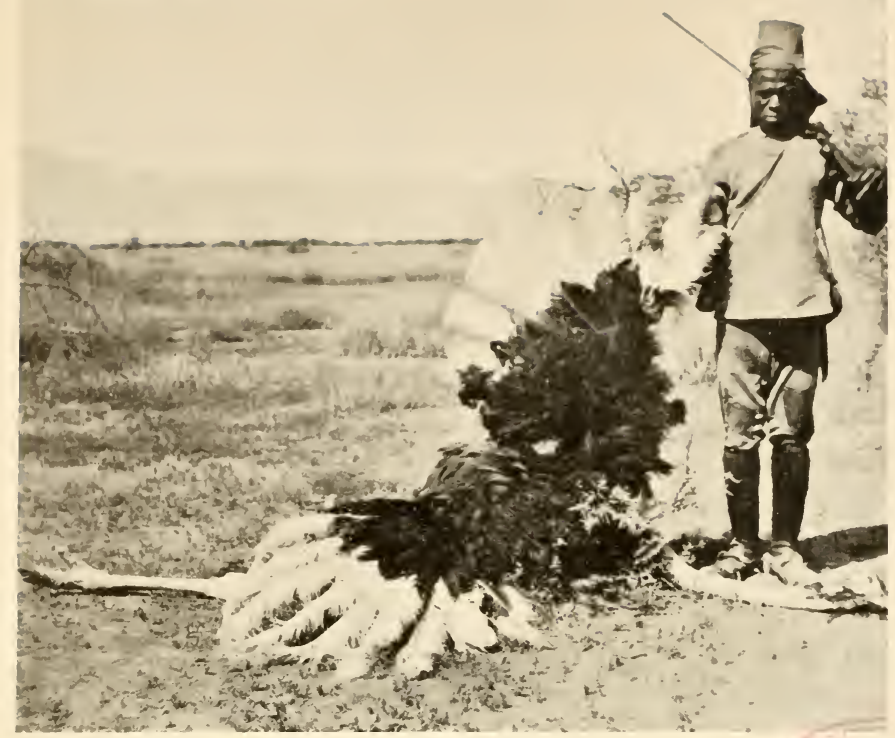

A COCK OSTRICH IN FULL PLUMAGE

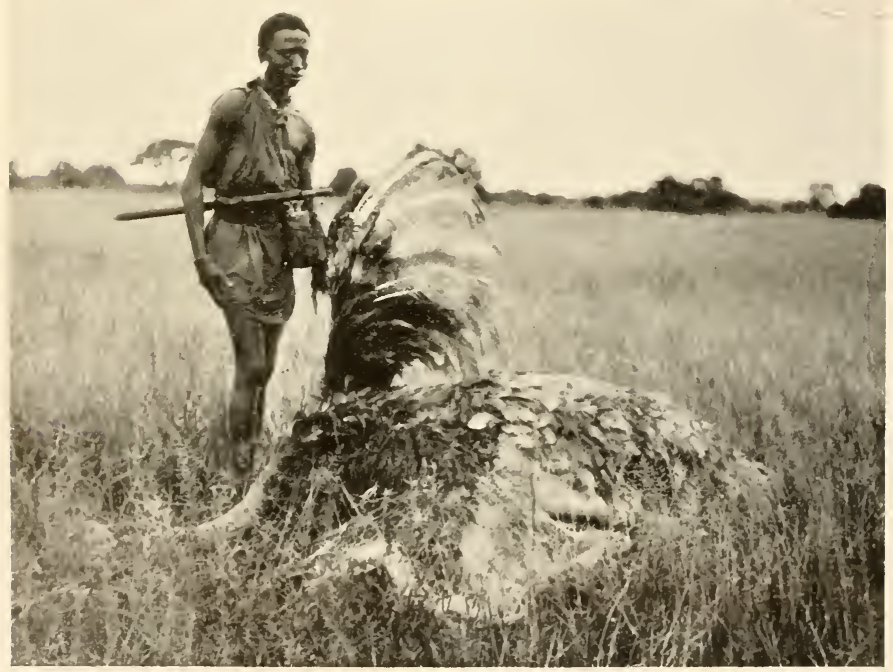





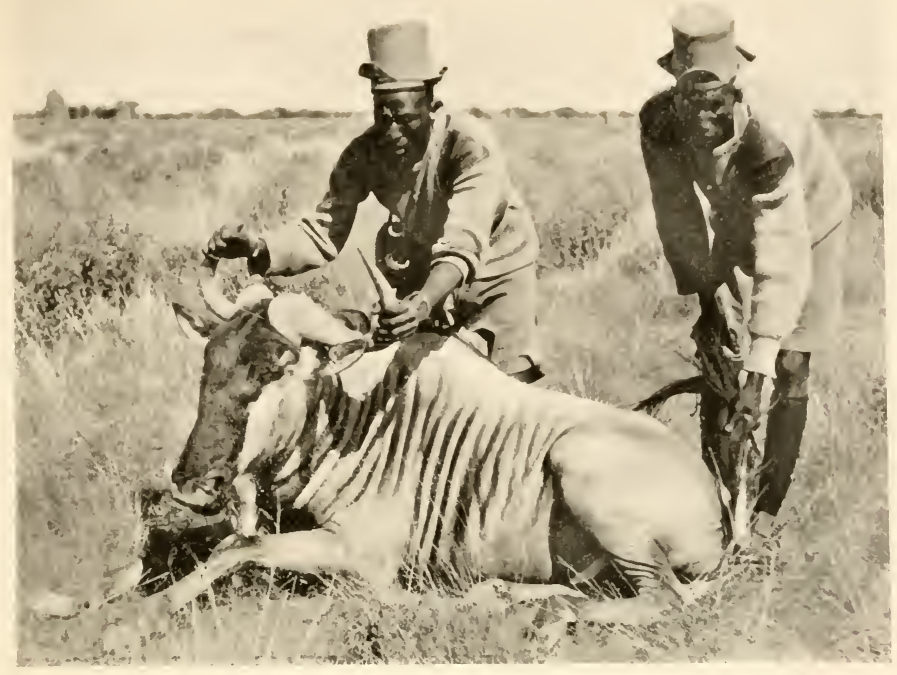

A BUtL. WILDEBEEST

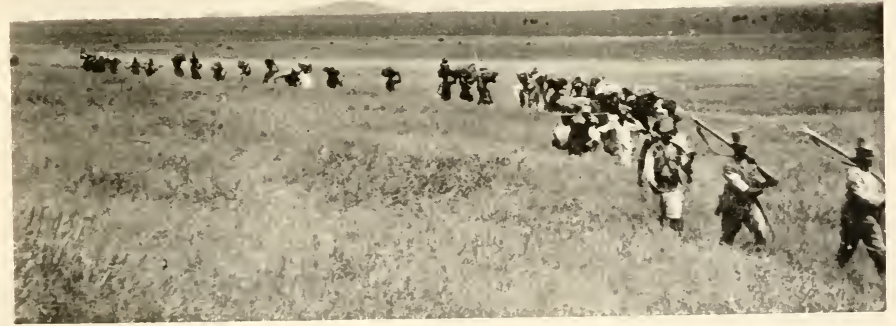

A "SAFARI" ON THE ATHI PLAINS 



\section{Wildebeest}

An old stray bull will often be found impressed to do "sentry go" for other game.

When they are disturbed they go off at a lumbering gallop, whisking their tail round in a circle, but they cover the ground to some purpose. When wounded badly, and one gets to close quarters, they will as often as not charge, or try to, with a snort.

They are as a rule distinctly shy brutes, but I do not think they are very hard to stalk.

I have found the Wildebeest on the Athi Plains in small numbers. I fancy he wanders in smail herds in that district in the dry season in search of water and green grass by the rivers. I came across a very large herd indeed, of fifty at least, on the Guaso Nyiro on the German boundary, and then, with a distinct break, afterwards under Kilimanjaro in the same large herds. 


\section{HARTEBEEST \\ BUBALIS JACKSONI. BUBALIS NEUMANNI. $B U B A L I S$ COKEI}

Swahili : Kongoni. Masai : Olkond

7 HE three kinds of hartebeest that occur in this country had almost better be bracketed together for the sake of describing their habits, which will, I think, be found to be identical in every case.

The Jackson's, Neumann's, and Coke's hartebeests differ rather uniformly, if I may use the word, when taken in the above order.

The ground colour in the three species is rich fulvous fawn, darkest in the Jackson's, lightest in the Coke's. The Jackson's face goes to the darkest shade of the three; and the rump of the Coke's is lighter than the others. All three, in shape, stand very high at the withers, and their backs slope down to their quarters.

The horn pedicle in all is high, highest in the Jackson, lowest in the Coke. Jackson's horns go roughly straight and $\mathrm{V}$-shaped up before they bend backwards; Neumann's bend more outwards half-way up, looking at the head end-on; 

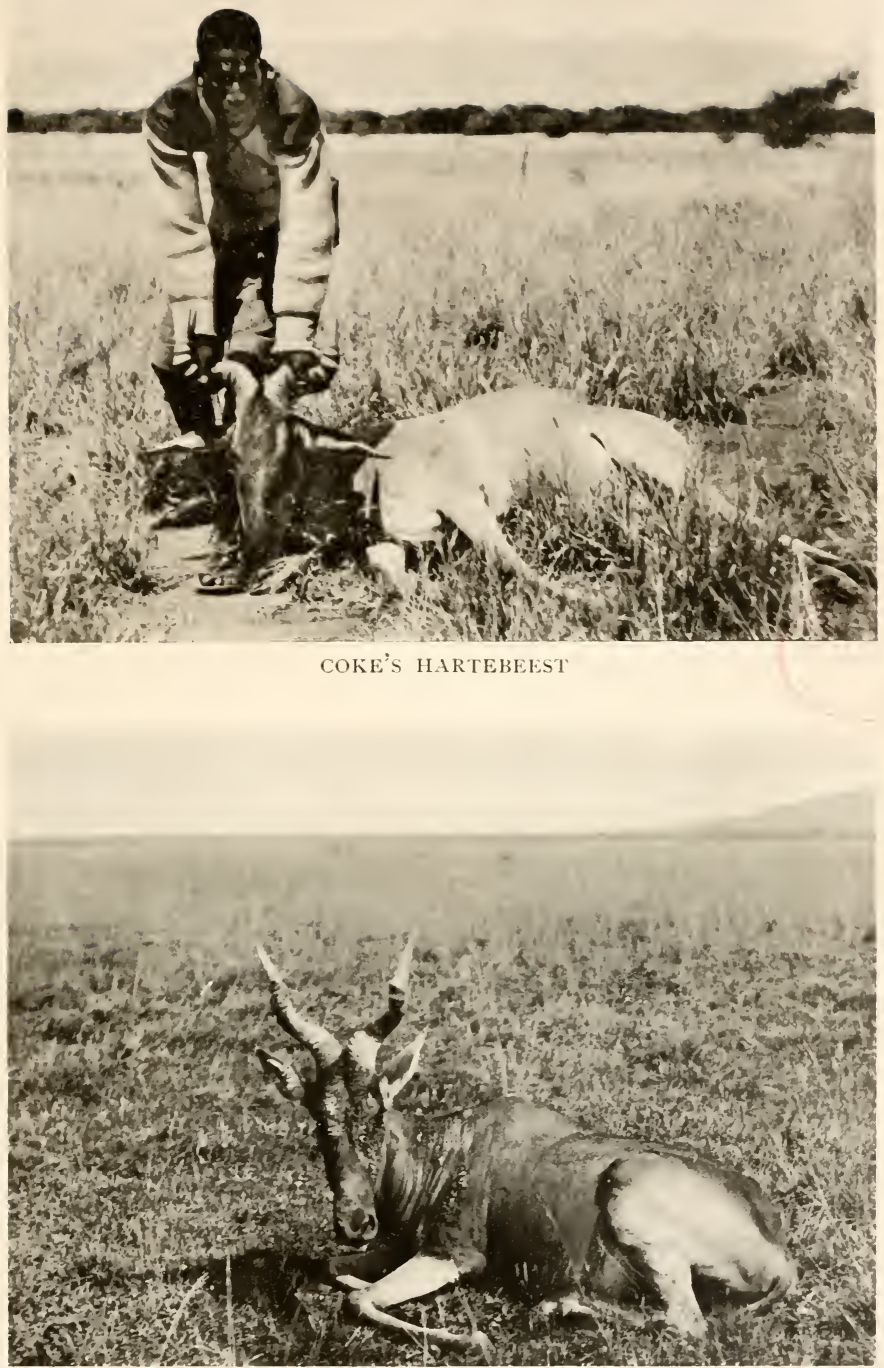

NEUMANY'S HARTEBEEST 



\section{Hartebeest}

whilst Coke's are almost exactly like an inverted bracket, ascending quite a short distance, bending out at right angles, and then upwards and backwards. Jackson's carry the heaviest and longest head of the three kinds.

But they are as easily known by their heads as by the district they are found in, which I am taking in the same order as that which I stated, and which may be said never to alter.

Jackson's are found more north and across Lake Victoria than the others, across the Mau escarpment to Lake Baringo, and on Laikipia now and then. Then comes Neumann's, north of lakes Nakuru and Elementeita to Lake Solai in the Rift Valley, and underneath the Aberdare Range on the foot-hills from the north. Last of all, from Naivasha to Kenia, and thence across the Athi Plains to Kilimanjaro, and a little beyond, come the Coke's.

I am leaving out a variety about which nothing certain is known, that I have heard much aboutthe hybrid hartebeest, between Jackson's and Coke's. It was supposed that all those that I locate as Neumann's round Elementeita were hybrids.

The Dutch gave them the name hartebeest, being "hard beasts" to kill. They have great vitality and will carry a lot of lead. I shot one lately, with one bullet in the base of the neck, and another in the lungs, and then had to give 


\section{Big Game Shooting}

him three more in a quarter of an hour. But that is really quite a common occurrence.

They are extremely numerous each in his own district, and are the most difficult beast, I think, to get close to, as they invariably have their sentries posted in a wonderful fashion. In fact, so vigilant are they that it is a well-known thing, and very common withal, that other species of game have two or three hartebeest tacked on to their strength to help keep watch for them.

A gallant major, who is a well-known sportsman in Siberia, told me that he had christened them "nasty beasts," and I was not surprised either!

One has to take up one's rifle prepared to shoot really straight, as unless hit in the right place at the first time of asking, you may follow him for a whole morning or more, and then lose him. It is wonderful what a distance they will go with a "swinger."

Their flesh is coarse and not much good for eating.

To my mind every hartebeest head is spoilt unless one keeps the mask, as, their faces being so long and cadaverous-looking, it is only their ears that help to save the situation, when set up on the walls of one's baronial hall.

Talking about long shots, these are the only animals, Coke's in particular, which it is permissible to take on at three hundred, or some- 


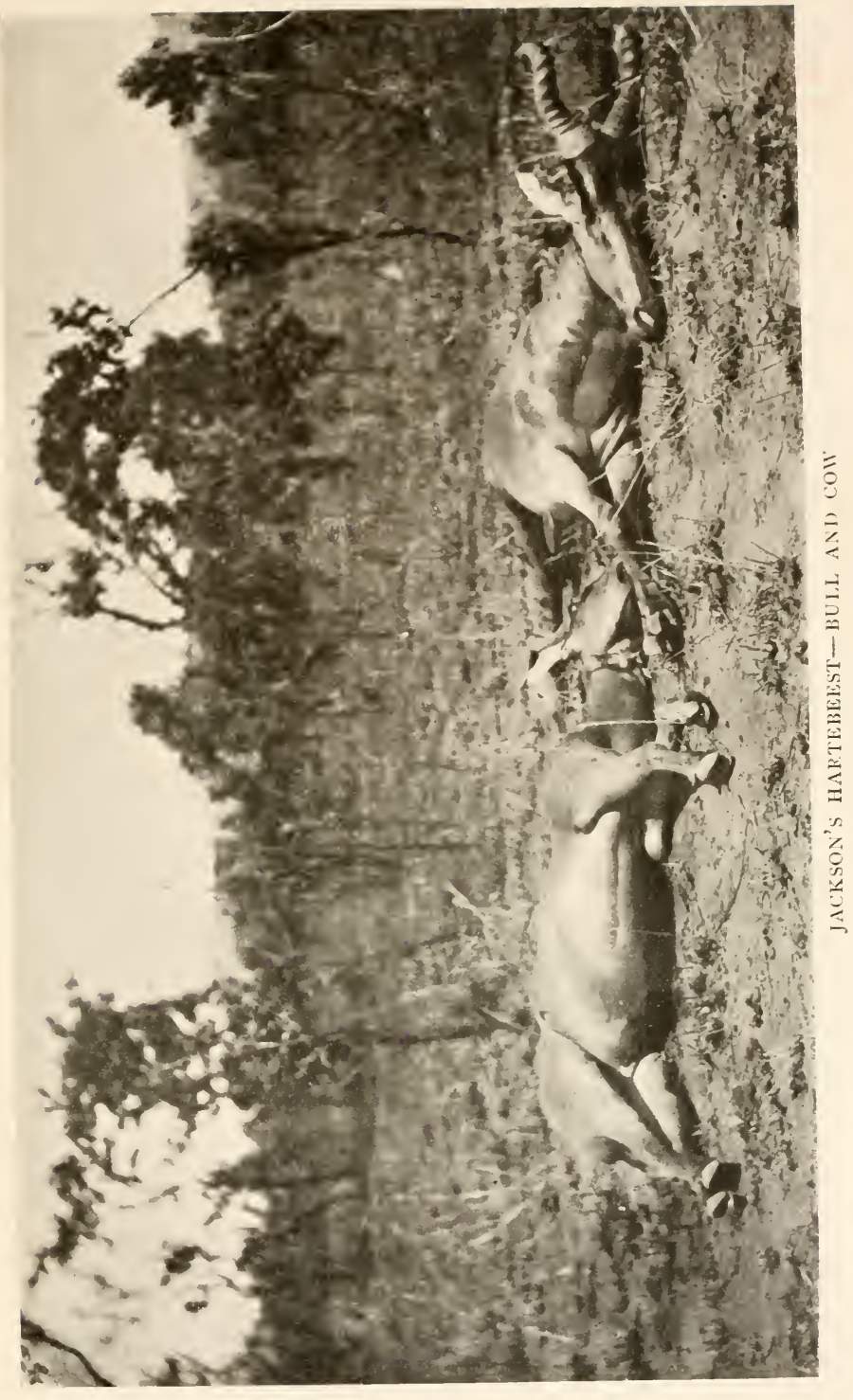





\section{Hartebeest}

times four hundred yards. On the bare expanse of the Athi Plains, where there is never a bush, and not enough grass to crawl in, it has to be done.

I have found Jackson's in herds of from five to twenty, Neumann's about the same, and Coke's from ten to one hundred. The latter are by far the most numerous.

All hartebeest want a certain amount of water, but I should say do not necessarily drink daily.

If one manages to get near a herd unobserved, they invariably stand and give one a second shot in twenty or thirty yards, if frightened suddenly.

When galloping they go off with an easy lolloping canter, moving very high and springily, with all four legs distinctly off the ground at the same time; so they make tremendous headway through long grass.

When found lying down in the middle of the day, three or four are invariably seen posted round the herd, usually standing on old antheaps, or on a little rise. 


\section{TOPI \\ DAMALISCUS JIMELA}

Swahili : Kongoni. Masal: Kinyangoswa

NEAR relation to the hartebeest, but
distinguished chiefly by its shorter
face and different shaped horns, is the
topi.

It is sometimes called "topi hartebeest," but as its Latin name is "Damaliscus" as against "Bubalis" of the true hartebeest, this is a misnomer.

The topi is smaller, however, and its horns are short, thick, and heavily ringed, being very often much worn and broken at the tips; they bend slightly outwards and then try to meet, whilst slanting backward all the way. The cow carries a head as well, thinner, as usual, but extremely hard to distinguish, in a herd, from a male's. I remember well my sickness at my first two. I made certain they were both bulls, and the biggest in the herd to boot, but found I had made another error.

In colour the topi is darkish brown, with curious purple-black markings on his face, flanks, and fore-arms. 


\section{Topi}

They are difficult to approach, but as they inhabit more bushy country than the hartebeest " of commerce," they can be more easily stalked. They also have sentries posted out, but are not so careful. It is rather hard sometimes to get close to them, as, there being trees about, they are apt to spot one first and then disappear, after having had a good look at one before they are seen themselves behind a bush. I fancy in that case they do not give one a shot again, but clear straight away.

They are found in tens or so, and in big herds.

They are very common in Jubaland, and swarm on the Anglo-German boundary, near Lake Victoria. Mine I got near Mohoroni, on the Uganda railway, where they are fairly common. The country there is long grass-which is very wetting-sparsely dotted with thorn bushes and trees.

The topi also bounds when he moves, like a hartebeest.

The purple markings on the skin make them quite distinguishable when one first sees them, and they are rather striking-looking. Also the purple mask helps to set off the otherwise somewhat ordinary-looking head and horns, and should be preserved, as is, of course, my invariable rule.

Fifteen inches is an average head. 


\section{THE ZEBRA \\ EQUUS GREVYI AND E. BURCHELLI}

Swahili : Punda-millia. Masai : Ol-oitigo

7 HIS is far and away the most annoying animal that is to be met with in the jungle. To begin with, they run it very hard indeed with the hartebeest for widespread distribution, being met with everywhere. To go on with, one is just getting to within nice distance of some animal one has had great difficulty in stalking when suddenly, without the slightest warning, a beastly zebra gets in the way, and gallops off, alarming the animal one had begun to think was as good as dead, and everything else on the face of the earth as well.

It is very few zebra that have enough sense of decency to disappear quietly; they usually neigh in the most shocking way, and that in a most peculiarly high-pitched tone. To any one new to the country, it is rather like the barking of a fox, but repeated several times and very quickly indeed.

They are striking animals, with their broadly 


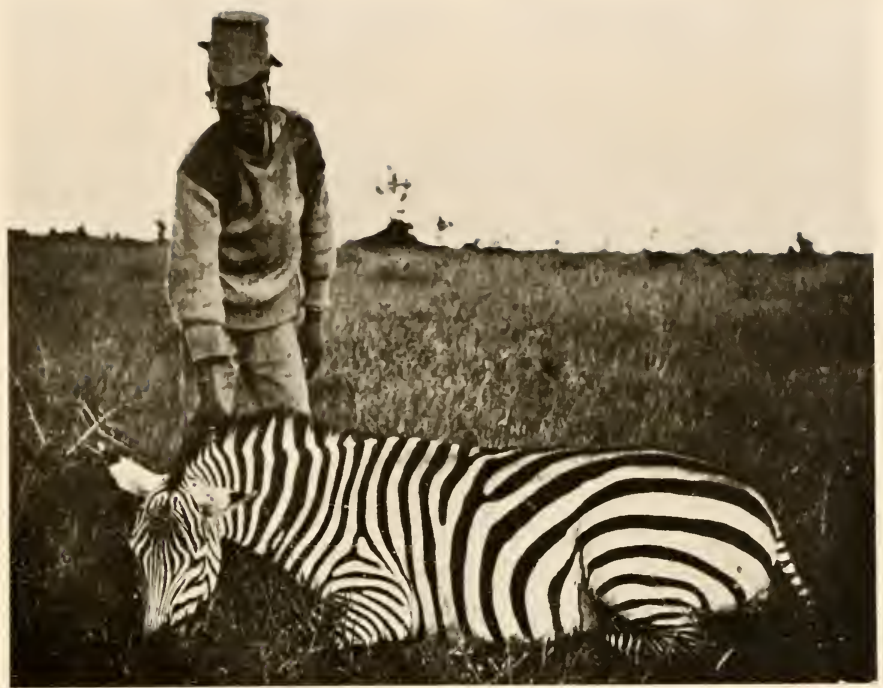

BURCHEI.L'S ZEBRA

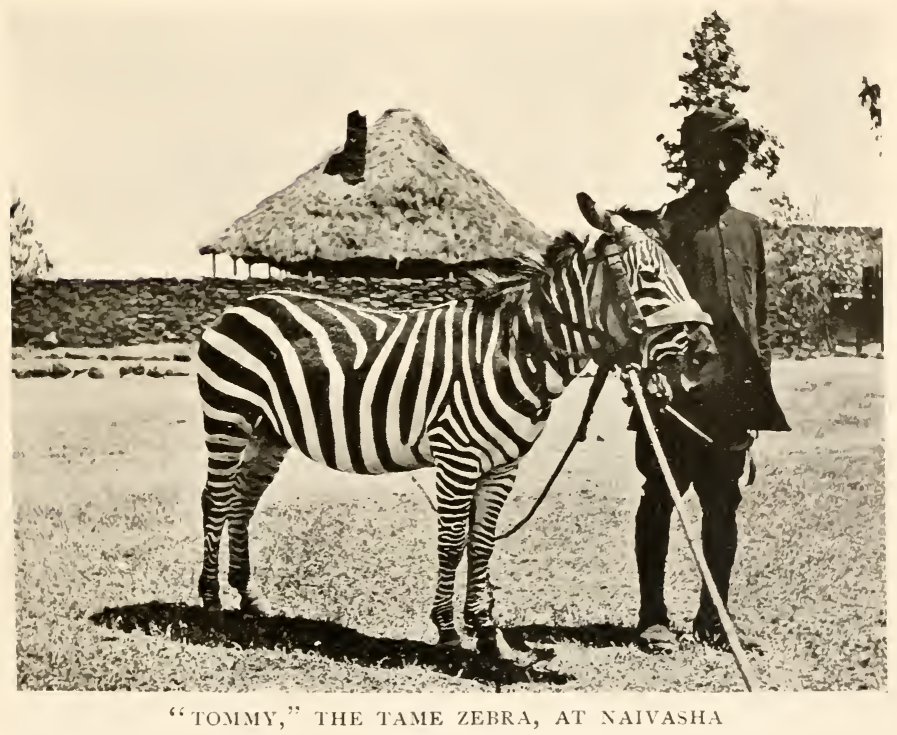





\section{The Zebra}

striped skins, finely pencilled faces, and hog manes, added to which they usually look nice and sleek and well-cared for, but that by no manner of means makes up for their ruffianly habits and noisiness. No one wants to shoot one except as "meat for the porters." The flesh is too tough and strong for the white man.

Both species are to be met with in British East Africa, Grévy's and Burchell's. Grévy's zebra is much bigger than Burchell's, and is much more narrowly striped; besides, the stripes on the flanks and quarters do not turn backwards as they do in Burchell's (as the pictures of the latter show), but run up nearly straight almost to the black stripe down the back, from which they are, however, separated by a narrow space of plain white. The latter is the kind ordinarily met with.

No! I hate the zebra. $\mathrm{He}$ is a very "loud" animal, taking him all round.

They have been caught in large herds for the purpose of trying to domesticate them, and of breeding from them by crossing the mares with pony stallions, but with small success, I fancy. The capture of them is undertaken by a few of the officials, who organize a large mob of Masai savages to drive the country for miles around, gradually closing in ; and eventually an old decoy zebra entices the herd, if the drive is at all successful, across a ford in a river into a specially 


\section{Big Game Shooting}

prepared "corral," the fences round which are concealed as much as possible and firmly braced in case the zebras took it into their heads to stampede.

The zebra farm on the Morendat River, near Lake Naivasha, is well worth going to see when they have any animals there. I append a photograph of the tamest there, "Tommy" by name, if I remember right, which was quiet in single and double harness, and had carried a lady. I once, however, saw a four-in-hand of zebras start from Naivasha railway station, and patted myself on the back that I was not handling (or hauling at !) the ribbons.

They are very common indeed, and wander about in herds of from ten to twenty and upwards of two hundred.

They are occasionally requisitioned by other animals to keep watch for them.

The native is very fond of their flesh, and is always begging one to shoot them. 


\section{BUSH-BUCK \\ TRAGELAPHUS SCRIPTUS}

\section{SWAHILI : IMBAWARA}

THAVE never shot a bush-buck, and it has been my ill-luck to have met them on very few occasions.

They are bright foxy-red in colour with numerous white spots and stripes on their body, and are easily recognizable by their shortish straight horns, which have a twist on them rather like that of an eland's horns. Females carry no horns. These animals are, no doubt, closely allied to the harnessed antelopes.

They are very wary and secretive animals, being only met with in thick bush, on hill-sides for choice, and they are hardly ever seen, as they keep themselves to themselves.

The only way to get a shot at one is to make a business of it, and go out along a native path to some small clearing in the forest, arriving there about 4.30 p.m., and sit down quietly by oneself and wait motionless. If the locality is in any way frequented by bush-buck, in half an hour or so a shrill whistle will be heard. That is the 


\section{Big Game Shooting}

bush-buck calling and being answered from all round. Remain quite still, and perhaps one of them may condescend to show him or her self. If not, do not be disappointed, but return next evening, and wait for your buck.

If one does appear, it behoves one to shoot straight and quickly, as they will bound off into the bush and hide themselves in less than no time.

They are widely distributed, so it is impossible to give any strict directions as to locality, except that one should scour the forest-land for them.

An average head will measure sixteen inches. 


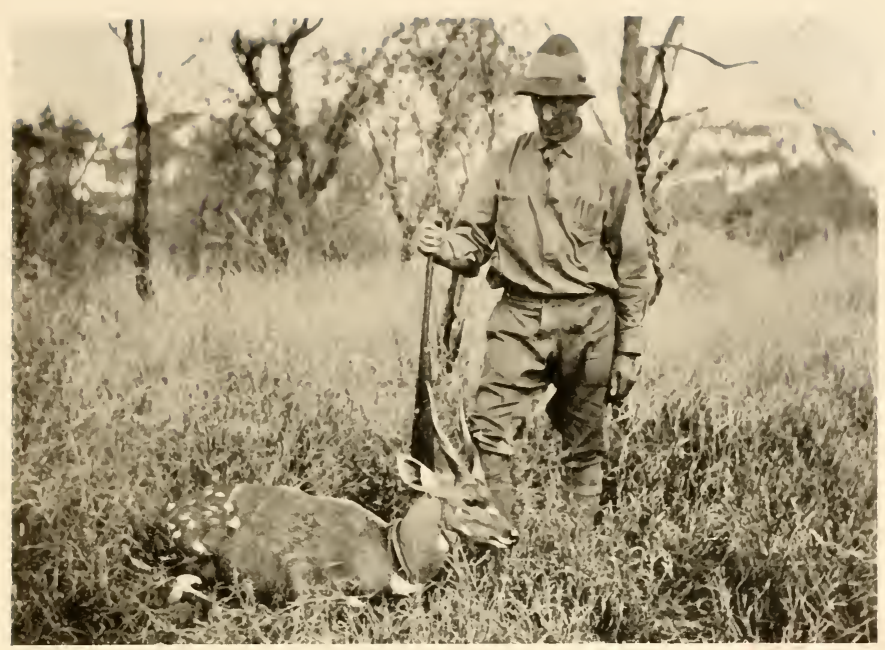

A BUSH-BUCK

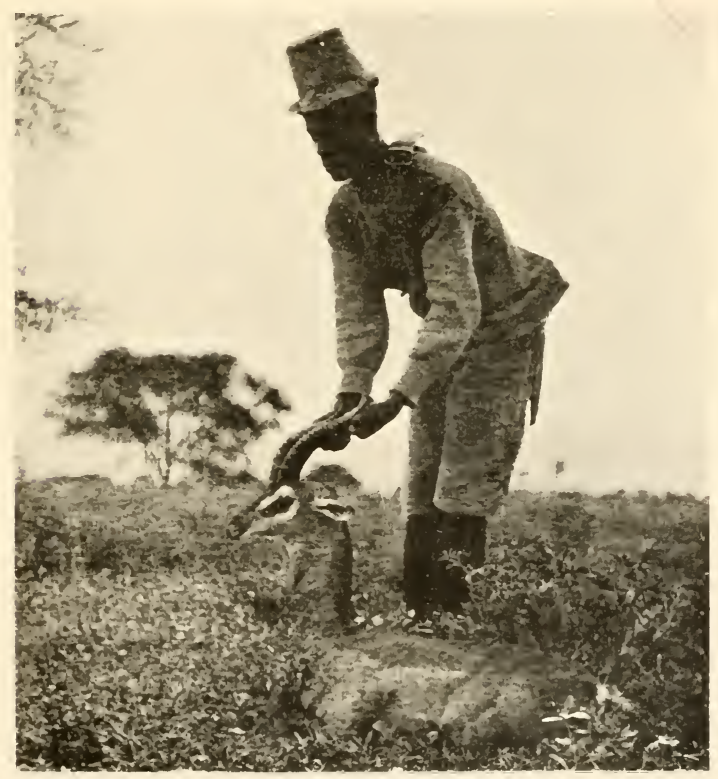

WALLER'S GAZELLE 



\section{WALLER'S GAZELLE}

LITHOCRANIUS WALLERI

Swahili: Swallah. Masai : Nanjaat

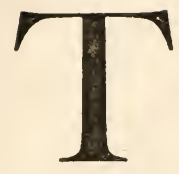

1 HE Waller's Gazelle, or Gerenuk, as it is called by the Somalis, is one of nature's freaks in the antelope line.

It is in colour of a rufous fawn all over, with a broadish darker line along the middle of the back. It has an abnormally long neck, and the head is very nearly six feet high when the animal stands up on all fours. As its neck is to the body of the giraffe, so does the gerenuk's neck compare to the body of this strange beast. Its legs are also longer and more slender than are usually found in other species of antelopes.

The male carries thickish ribbed horns, oval in section, curving back and then sharply forward at the tips; whilst looking at them end-on they are lyre-shaped.

One of its chief peculiarities is that when grazing on thorn bush, which forms the chief part of its diet, it stands on its hind legs like a goat and draws down the top branches with its forelegs, and so can reach very high up on to the bush with its long neck. 


\section{Big Game Shooting}

They seem to care very little for water, as they frequent very barren country indeed, country that in the dry weather is burnt up, and with no water within miles. I have never come across them drinking in Somaliland, where they abound near Hargeisa, or for the matter of that in East Africa ; in fact, they should be hunted for in any suitable barren, desert, dry parts, and then only in certain districts which are known to be inhabited by them.

When running they do not often gallop or bound in the usual gait of the antelope, but they run carrying their heads low down in a straight line with their backs, as if to afford them greater cover from view. This is very much more noticeable in Somaliland than in East Africa.

From experience, I think they are very much harder to get at here, unless the sportsman can spot them before he is himself seen. They are found in herds of one buck to usually two females. A single buck is as a rule a good head.

It is not at all improbable that if either gerenuk or lesser kudu are seen in a certain place, the other will be found there, or thereabouts, as well. This applies to Somaliland equally with East Africa.

Some say their meat is hard and coarse, but I think it will be found to "go down" all right. In East Africa they are found in certain 


\section{Waller's Gazelle}

districts only, on an open, dry, stony plain, rather more commonly than in Somaliland; but there will be fairish cover at no great distance. Round Kilimanjaro they affect bush country with long grass and boulders; in fact, any one who has shot them in Somaliland will recognize their whereabouts in a twinkling.

They are "local" beasts.

Their only habitat in East Africa is the country round Kismayu, the Taru Desert, and thence to Kilimanjaro and as far north-west as Lake Magardie, where they will be met with in considerable numbers.

A good average head will be fifteen inches. 


\section{GRANT'S GAZELLE GAZELLA GRANTI}

Swahili: Swallah. Masai : Ngoldi

7 HIS is a splendid gazelle to look at as he wanders about, more on account of the length and thickness of his horns compared to the size of the animal, and the graceful way in which he carries them, than anything else. It is rather surprising that such a comparatively small animal can carry such a big head as he does.

$\mathrm{He}$ is so common, and his markings and colour are so well described in different books, that I need make no comment beyond saying that he is sandy-fawn. He has rather a podgy nose, that makes him look as if he had a badly-stuffed head. The female carries horns, thin, and as a rule about twelve inches long, and has a black stripe on the flank that is absent in the mále; in fact, she is like a male Thomson's gazelle. The buck is most misleading with regard to a big head. I find that the apparently splendid head in a herd, which sticks well up in the air and can be seen a mile off, is nothing like as good as the 


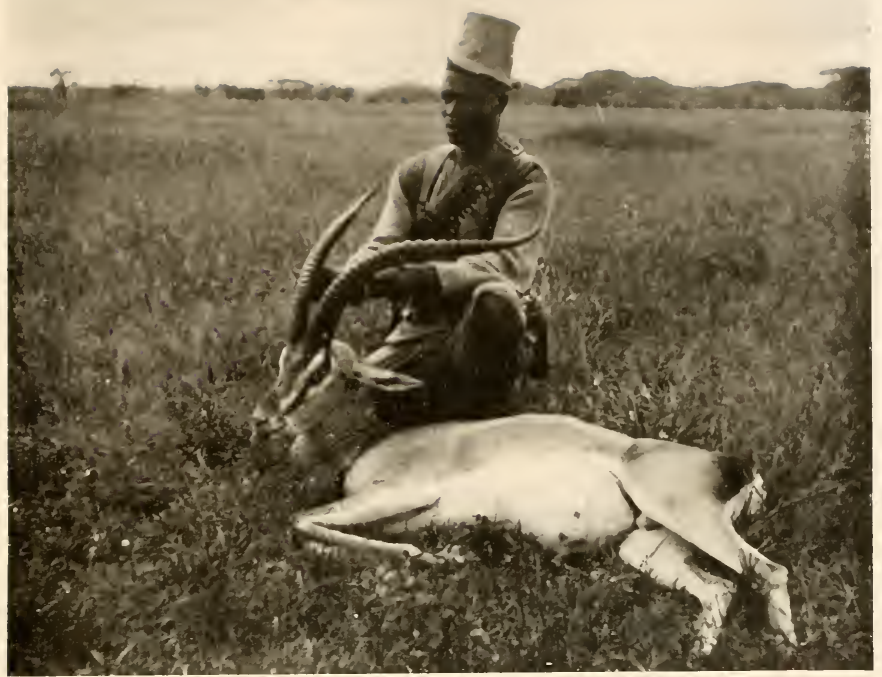

GRANT'S GAZEILE

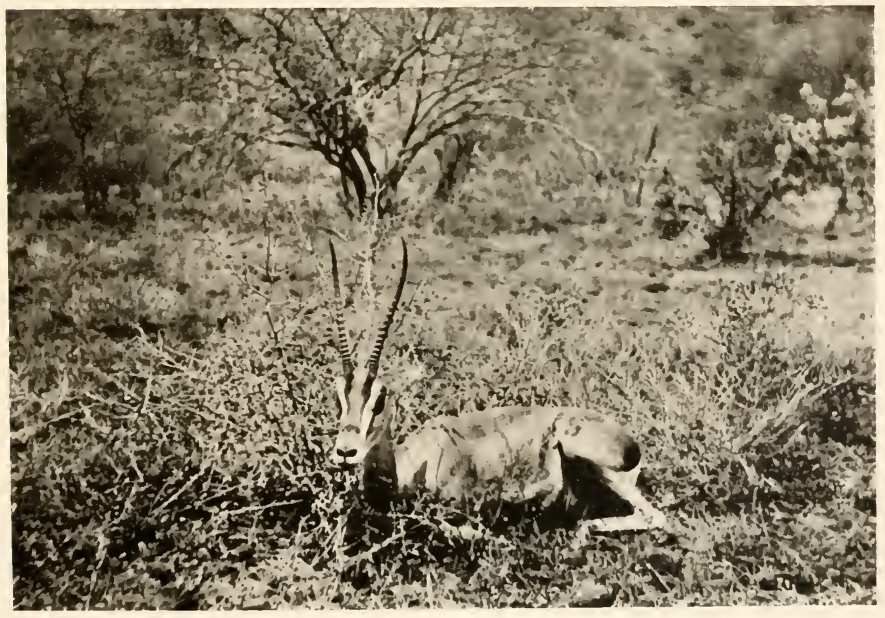

A FEMALE GRANT'S GAZELLE 



\section{Grant's Gazelle}

seemingly smaller one that lies well down with a big backward sweep. It is extremely hard to make up one's mind whether or not to shoot a Grant for his head, for that reason.

They go about in herds of ten to fifteen or more, and in threes, and also may be met with singly occasionally. Again, this does not mean that a solitary buck has an exceptionally good head. The buck walks rather towards the end of the herd unless he is badly frightened, in which case he leads till he is five hundred yards or so away. The bucks fight like anything if they come across an intruder into the herd. On such occasions it is comparatively easy to approach them, as they are so occupied with their adversary. Sometimes they are quite tame on an open plain, at other times they are very hard to get at. It seems that if they think they dislike the looks of one they bolt, and then, when far enough away, they break into a trot, and afterwards go at a walk for a bit, and when one gets closer they will break into a trot again; and so it goes on in a most exasperating way.

They frequent stony and almost barren plains, and undulating country generally, with a sprinkling of bush.

When they are alarmed they sneeze like a goat, and they seem rather inquisitive.

They are never found in or near a forest.

If one has shot a buck, the herd very often 


\section{Big Game Shooting}

stands a little way off, so that one can pick out another buck if necessary.

This species, zebra, and Coke's hartebeest might almost be said to have a hard fight for it as to which is the most common. Their saving clause, when mentioned with the above, is that they do not do "sentry go," and do not give such a fearful signal for retreat when they bolt as do the other two species.

They swarm round Kilimanjaro to the Athi Plains and right away to, I suppose, Baringo as well as Laikipia, and over the Guaso Nyiro, and I am sure further north.

From my experience, one gets a much bigger head in the south round Kilimanjaro than one does north on the Guaso Nyiro. Twenty-three inches was my best in a month's shoot on Laikipia, whilst I managed to bag a beautiful buck $30 \frac{1}{4}$ inches under Kilimanjaro.

Twenty-eight inches is a nice head, and the bigger spread the better. 


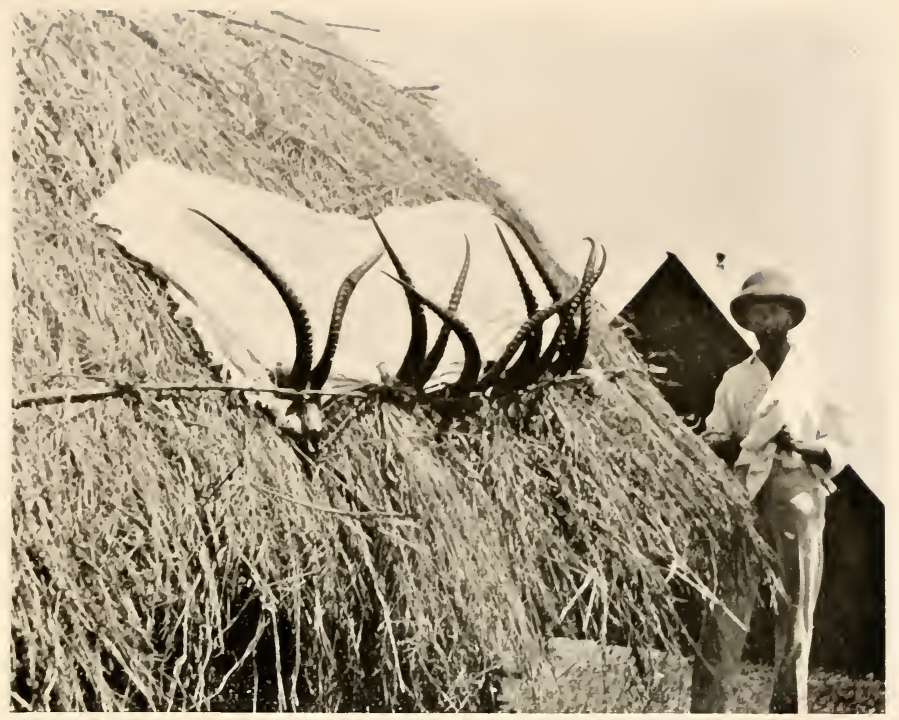

SOME HEAIS OF GAZELLA GRANII-ROBERTSI

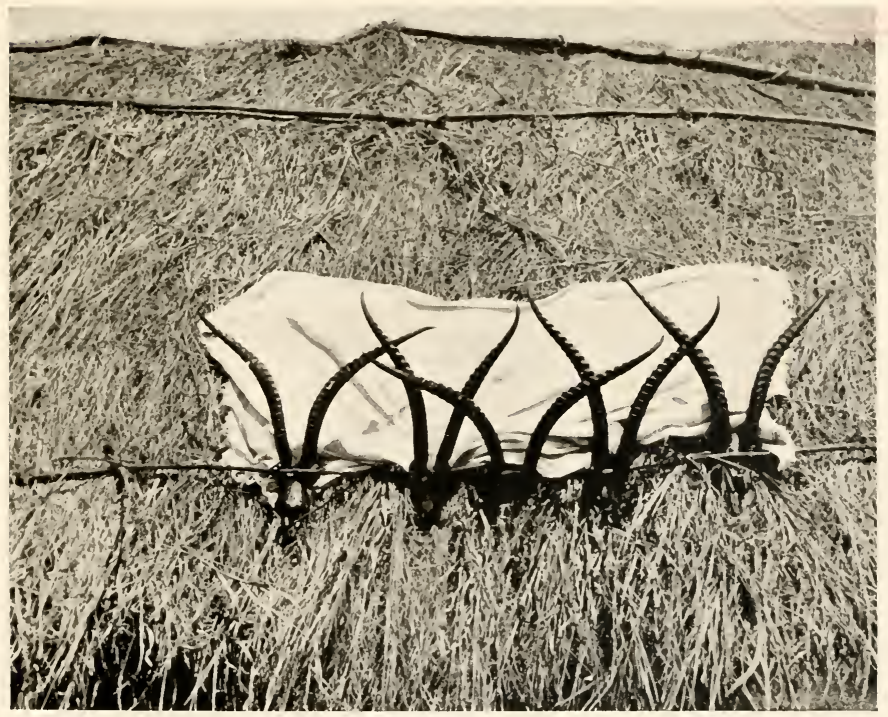

THE SAME AS ABOVE A'T A DIFFERENT ANGLE 



\section{ROBERTS'S GAZELLE}

\section{GAZELLA GRANTI ROBERTSI}

7 HERE has been discovered a new species, or perhaps variation would be the correct term for it, of Grant's gazelle in the last few months by $\mathrm{Mr}$. Russell Roberts, designated as above. I have been lucky enough to obtain a head on the Anglo-German Boundary Commission, very small it is true, but showing the characteristics partly.

$\mathrm{He}$ is exactly the same as the Grant's "of commerce" in colouring, but the difference is in the head. The horns start straight like an ordinary Grant's, but almost at once begin twisting inwards, so that the tips bend backwards.

In an oldish beast the spread of the horns is enormous, and is quite ugly, and in the ordinary Grant's abnormal. My head shows the twist, but one of the photographs of five of the best heads of this animal, shot on the Commission, which I insert, shows the extraordinary spread of its horns, more especially that of the middle one. I hear that there is a head of a Robertsi in the German station Sherati, on the Lake, with a bigger and much flatter head than the one depicted. 


\section{Big Game Shooting}

It is most uncommon and more than "local" in my use of the word, as it is only met with in two or three places, and quite small places at that. Mine came from Ndesegara; on the German boundary. I do not know where Mr. Roberts shot his. 


\section{PETERS'S GAZELLE GAZELLA PETERSI}

Swahili : Swallah. Masal : Ngoldil

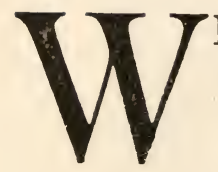

E now come to this rather rarer animal, which can be broadly described as a very near relation to Grant's gazelle. Formerly it was only known in the coast districts north of Mombasa, through Lamu and Witu as far as Kismayu, with here and there an outlying herd or two in certain parts further inland. I, in common with a few other sportsmen, have found it in a comparatively new place, on Laikipia. The specimen I secured was pronounced by competent individuals to be an undoubted Petersi, but on account of its being a very good head and the fact of the skin having had to be destroyed introduces a certain doubt into the minds of others.

$\mathrm{He}$ is a little bit like a "Tommy," and very much like a Grant's gazelle, but rather smaller than the latter. There is also a difference in the colour of the tail and adjacent parts, the Grant being white at the base, which colour also surrounds the part where it is set on, whereas in 


\section{Big Game Shooting}

Peters's gazelle the base of the tail is brown, which runs up gradually to the brown of the back.

His habits are the same as either the Thomsoni or the Grant, as one finds him mixed up with both in the same country.

I have only met with three herds, so prefer not to say much about them, although I think there is little more to be said for that matter, as their habits seem to be the same as the two species mentioned in this connection.

One herd I met on the Guaso Narok not far from its confluence with the Guaso Nyiro, and the other two herds on the other side of the Guaso Nyiro, about twenty miles farther north again. They frequent open rolling plains, and I met herds of eight, six, and eleven. One or two bucks go to the herd.

I am inclined to think that in that country it is a matter of taking careful observations through glasses, as probably many have been casually let off on account of the small size of their heads compared with the surrounding herds of Grant, and therefore that people think they are of necessity a very small Grant's gazelle, and therefore not worth shooting. Otherwise more might be found in that district.

An average head will go seventeen inches. 


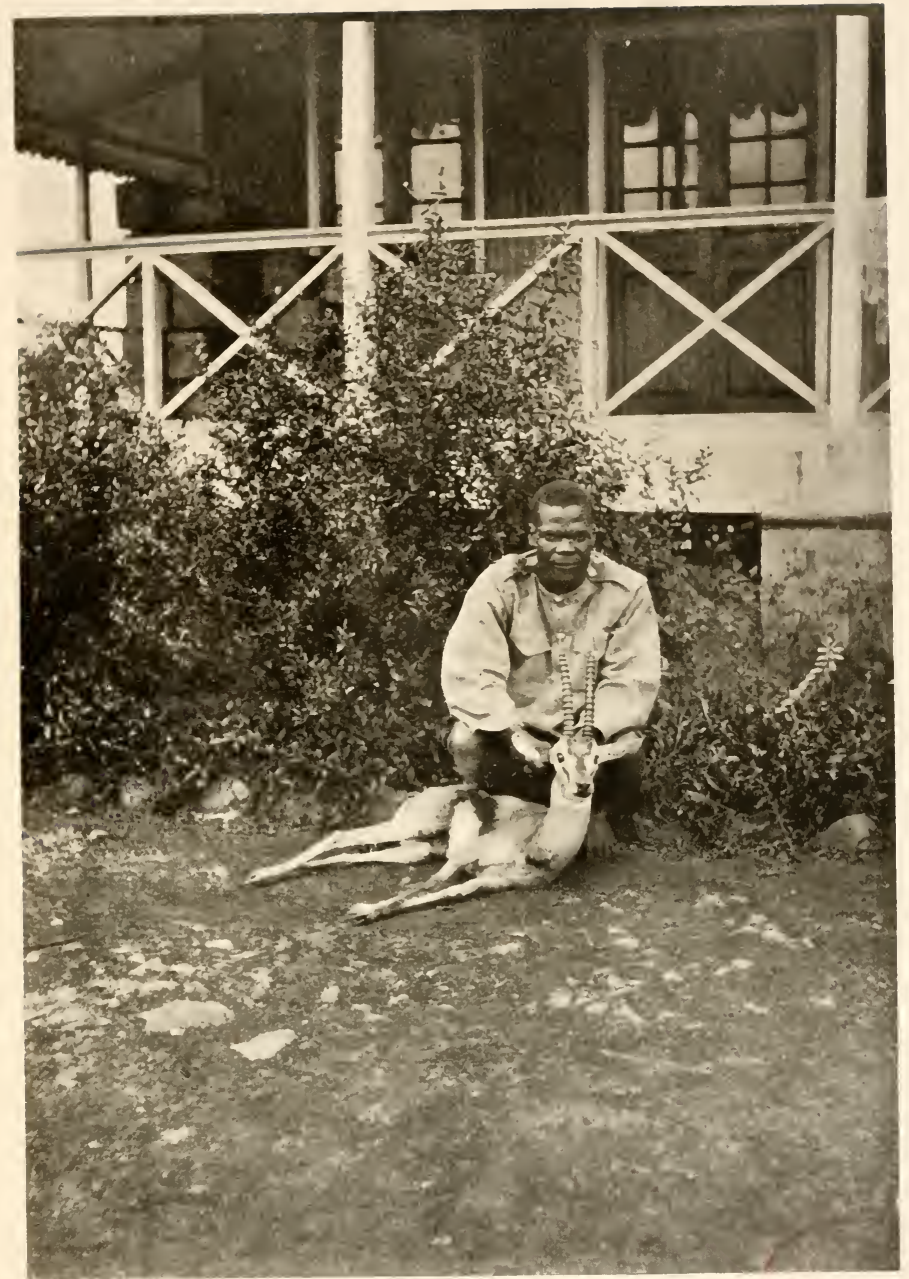

THOMSON'S GAZELLE 



\section{THOMSON'S GAZELLE GAZELLA THOMSONI}

Swahili : Swallah. Masai : Ngobära

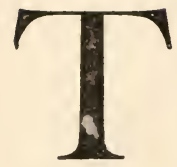

HE Thomson's gazelle, or "Tommy" as it is called locally, is so well known in East Africa as to hardly require a description. By the way, it is extremely awkward that the Swahili name for this, the Grant and the impalah are all the same- "Swallah." This is most misleading on occasions.

It is a deep sandy-rufous, with a black nosepatch, and has a broad, clearly defined black band dividing the white of its belly from its back. The horns are ringed and rather frontal, curving slightly backward, and straight when looked at end-on, with the tips smooth and bending forward a trifle. The female as often as not carries horns. They are to be seen with and without in the same herd. Whether they are easily broken or not, to account for that fact, I do not know, as I have never shot one with a broken horn.

They are pretty little things, and are found in herds of from ten to twenty and more. Those at Naivasha between the station and the Zebra Farm on the Morendat River are preserved. 


\section{Big Game Shooting}

They are as a rule very tame, and can be approached with ease in a country where they have not been much shot over. They are very good eating.

It is very easy to mistake this animal for a female Grant, at a certain distance, of course, and without glasses, or vice versâ, as each has the black stripes on the flanks.

I have found them on the south and east slopes of Kilimanjaro as far as Arusia in German territory, and across in small numbers to the Athi Plains, where they swarm. They are equally plentiful round lakes Naivasha and Nakuru, and extend northwards in considerable quantities up the Rift Valley to Lake Solai; thence over Laikipia, and all down the Guaso Narok to its junction with the Guaso Nyiro some way north.

A good average head would be $13 \frac{1}{2}$ inches. 


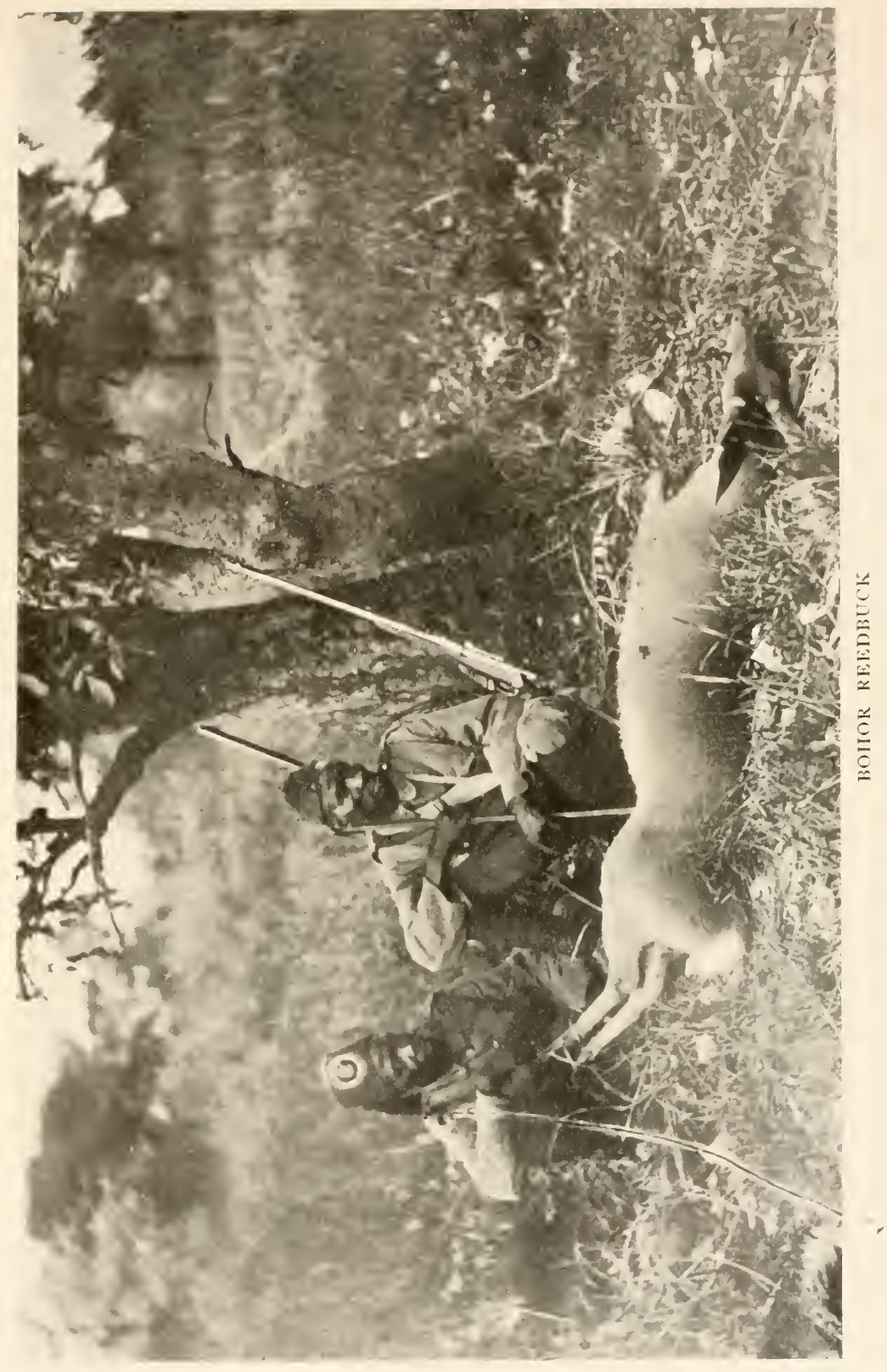





\section{BOHOR REED-BUCK}

CERVICAPRA BOHOR

Swahili : Kari. Masai : Mbarras.

7 HE reed-buck is a not very distant relation, I believe, of the water-buck family. They are easily distinguishable by their shortish horns, hooked forward, and by a bare black patch of skin under and behind the ear, added to which the bohor "of that ilk" is found in longish reeds and grass, never very far from water.

The female carries no horns. The horns are ringed at the base as far up as where they curve forward. The base of the horn usually tries to come off in flakes, but must be left alone.

The bohor is uniformly fawn-coloured, with longish, fluffy hair, and also has a bushy tail.

He goes about singly or in pairs, either bucks or does, singly or together. I have seen as many as four or five within the same half-mile, but should not call them a herd by any means.

When alarmed he utters a peculiar whistle, and eventually goes off, bounding fairly high above the long grass. They will not stand close for 


\section{Big Game Shooting}

a second shot as a rule, unless they have taken cover behind a bush for the purpose of seeing what is going on and watching one ; and then, of course, one cannot see them.

They are very good eating.

The bohor is not at all hard to stalk, and does not necessarily see one first, as is the case with most animals.

One has every chance of seeing them in the same place very nearly every day, so an awkward shot can be left till to-morrow; that is to say, they are "local." In the heat of the day they take cover away from, but fairly close to, water, in thick dry reed beds, and are then quite unapproachable, as they sit very tight at such times.

I have noticed, but do not know if it is a common occurrence, that on two occasions, when alarmed by a whistle from another buck, they squatted down in the grass on the spot, and I thought they had bolted. I saw this, and did not understand their game at first, so hid myself and stayed quite still, waiting for something exciting to happen; after a bit, however, they got up and started feeding again, apparently quite unconcerned. I do not know if any one else has noticed this. 


\section{WART-HOG \\ PHACOCHERUS AFRICANUS}

Swahill: Ngurruwe. Masal: Ubidir

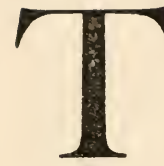

1HIS is a strange and weird animal, and fierce-looking withal. $\mathrm{He}$ is, of course, a pig, black and covered thinly with a few black hairs. Their skulls are rather flat, and they have three pairs of warts about an inch and a half long on their faces: hence their name. They are peculiar in having their upper tushes long, instead of the lower ones, as in the Indian pig.

They attain a much bigger size in Somaliland than in East Africa, added to which their tushes are longer still, and they grow a huge bristly mane in the former country, which sometimes nearly touches the ground. Their upper tushes curl over the nose at right angles to the line of their head, and the lower ones are quite thin and almost straight.

Their two main characteristics are amusing. First, when alarmed and trotting off, the tail is stuck straight on end into the air. Secondly, if one has the chance of riding one, and he has the 


\section{Big Game Shooting}

good luck to get to ground, there is a cloud of dust at the mouth of his hole, and one just sees him turning round and going down backwards way on in the middle of it. I take it he does that so that any unfortunate pig, on being violently pursued, may be ousted at once by a prod of his tushes. It might be stuffy for more than one, or again he might be thinking of his family affairs; but both views of him make one laugh immoderately on first acquaintance.

Pig-sticking has been started in Nairobi with some small success, and I have frequently ridden them in Somaliland, though usually there with a native spear, which lent excitement. On one's closing with them on horseback, they "come in" all right, but not in the determined way an Indian pig does. They may not have been brought up to a good charge, as the Indian pig has been, by generations of pig-sticking.

On being wounded with a rifle they may charge at times. I had one charge me in thick bush once, and it was quite unpleasant, as I was upset. He was hit high up and too far back, and I had managed to get him again in the act of charging, so he did no damage beyond a tear or two to my clothing.

They are found almost anywhere in grass and scrub jungle, so it would be useless to give special localities.

Eight and a half inches is a good tusk for a boar. 


\section{OSTRICH}

STRUTHIO MASAICUS

\section{Swahili : Mbussi. Masai : Sidai}

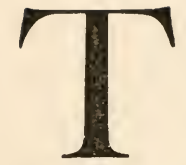

HIS fine bird may be counted as game, I take it, although it is not found in many books on the subject, but every one is anxious to shoot his maximum number-two-for the sake of the feathers, to give away to " his sisters, and his cousins, and his aunts," let us hope!

They are hardly worth shooting except when they are in full plumage, which is, I fancy, in November and May, that is, in the rains. A cock ostrich, as every one knows, is black-and-white; the hens, which one may not shoot, are light brown-the "natural colour" of furriers. A cock ostrich in full plumage is easily distinguished through glasses, as he has a red neck. If one is lucky enough to bag one "at six hundred yards running," this redness will be found to be in the skin, which has a covering of a nature more hairy than feathery. Excellent oil can be extracted from an ostrich by boiling down the fat, of which there is any quantity. It is excellent 


\section{Big Game Shooting}

when used as dubbin, or for the outside of guns and rifles, when one has run short of vaseline, or whatever one's peculiar grease may be. This is rather well worth knowing.

They are found on almost any plain, open or bushy, from Kilimanjaro right up to Northern Somaliland, and extend south as well, of course.

They may be seen in herds (one would hardly call them flocks) of from three to eight; fourteen I saw together the other day, and later still, under Kilimanjaro, I saw thirty-seven, all cocks, in single file, trekking hard across the plains like a train. I just saw a long row of heads over a rise, and then they all came into view. It was a very pretty and curious sight.

They have usually started running before one has spotted them. If one meets an ostrich at one hundred and fifty yards or so, stand still and let drive on the spot. It ought to be a "picnic" ; and being as astonished as oneself, they may just stand for the single shot.

They leave their nests half covered over with sand, and the sun helps to hatch the eggs. A single nest may have from ten to fourteen eggs in it. The eggs are very good. I remember, when wounded in Somaliland, one egg serving its turn three mornings running for omelets, and going down quite well.

On another occasion there I caught three 


\section{Ostrich}

young ostriches standing from two to three feet high. Amongst other food we used to put dates into their mouths, and press them down with our fingers. It was most amusing to see the doubtful look on their faces as to whether they would taste nice at the bottom or not. 


\section{AN IMPRESSION}

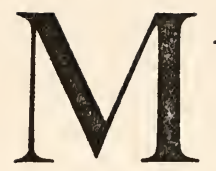

AY I attempt to describe a scene on my return journey from Kilimanjaro along the German boundary?

Imagine yourself standing on a solitary outcrop of granite rocks about a hundred feet high in the midst of a vast plain.

I looked at the sun setting in a cloud of golden glory due west, between two distant blue mountains, over the low blue ranges further off, over the hills and undulating rise and fall of the ground. There was light enough to distinguish that the foreground was waving green, shadowy grass that on the morrow would wet one to the waist with dew.

A long, long vista of greenery disappeared south-west between the hills, quite flat, growing narrower by degrees, and then darker as it caught the shade of the mountains. It vanished on the horizon quite blue, and quite suddenly into space. It vanished into the west, into the orange sky. It seemed like a road that had its way broad, open, and was calling on the travellers to follow it into the unknown. It was borne upon me once again that the "unknown" and the "peace" of an African wild are one and the 


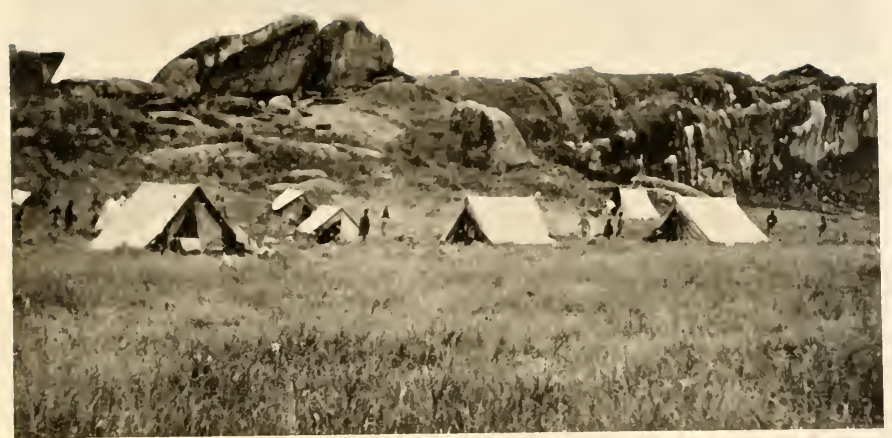

A TYPICAI, CAMP UNDER KILIMANJARO

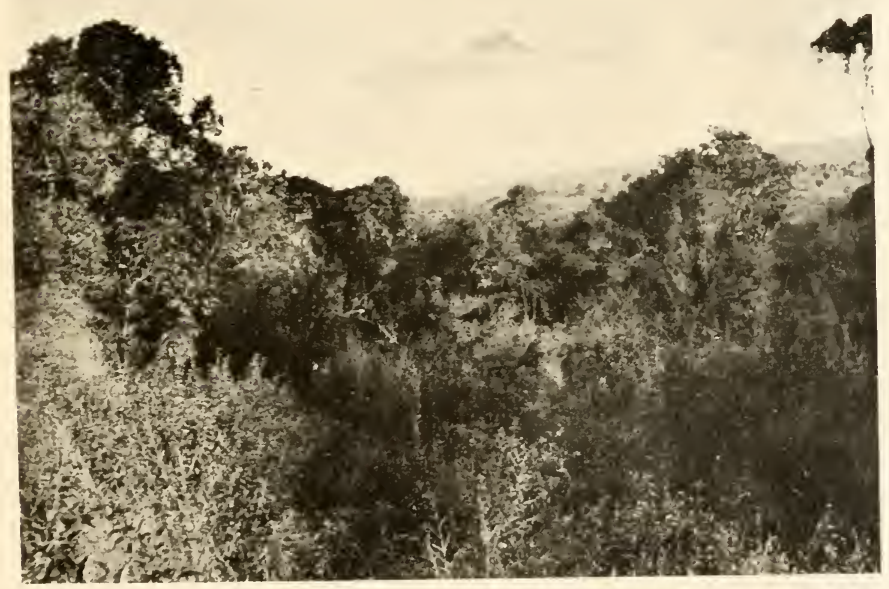

KIBAWENZI, THE LESSER PEAK OF KILIMANJARO AT MIDDAY 



\section{An Impression}

same thing. The invariable question comes"Where and what?" The answer as invariably one catches on the air, quite quietly, "Come and see"- - a mere whisper! I forgot camp noises, and lights and sounds. I was alone in illimitable space. I waved my arms and could not feel anything, as there was room! Nothing but space! Nothing but the birds and animals, the rocks and the grass, and myself. A few fleecy rose-red clouds lingering as the rear-guard of the rainy season floated overhead, whilst on the horizon to the north and south they hung grey and heavy-solid banks of clouds lowering and ominous, as if they intended themselves to frame the sides of the picture.

Longiedo and Erok-the former in German territory, the latter in English - rose sheer out of the waving sea of grass, craggy and fierce, like sentinels, each guarding their post on the frontier, ready to topple over and fight with one another. Blue and indistinct, with rings of damp white clouds near their peaks, their rugged outline showing clear against a turquoise sky, with the setting sun between them and colouring their inner edges purple-red, these two veterans, nature's obelisks of bygone times and countless ages past, frowned at one another.

A low misty blue ridge in the far distance found its home out of sight in the orange-red glow of the sun. 


\section{Big Game Shooting}

I turned round suddenly and descended a step or two. A mechanically-lit cigarette, a seat on the ground with my back to the rock and my feet in the grass, and I forgot the world.

Immediately, peace, perfect peace! The "Peace of Africa!" A peace which no one knows who has not been to see.

But I saw a sight that made me stare with wonder and amazement, whilst taking in the scene.

Framed in a deep blue sky, so clear and gradually turning into pale turquoise and shaded green on the horizon, the whole split into rays of pink with the after-glow (wonderful rays! right up into the heavens!), towered the snow-capped head of Kilimanjaro, the blue and purple of its lower slopes set off by a brick-red bank of clouds behind and in the far distance. I saw this wonderful spectacle, this everlasting sign of nature's stormy moments, this monument set up to outlast ages and cycles to come, a huge mass that told me of fire and smoke-of earthquakes, tremblings and thunderous salutes from the hidden batteries of volcanic artillery discharged in the making of it. It told me of all this, and in the telling, its peaks were slowly changingquite slowly! White, yellow, yellow, orangerosy-red, redder, pale crimson-cold blue white! The sun had gone to rest.

If possible more imposing than ever, the 


\section{An Impression}

mountain was also at rest, white and frozen, with a full moon rising over its lower ridge and a star like a watch-fire just appearing above the snow.

All was hushed! The same peace overspread creation. The mountain, outlined clearly, ever more clearly, against the rose and green background, spoke of peace!

Close by! Again grass, nothing but grass, meets the eye on a dead-flat plain. More seas of grass, with the tiny birds that live and build their funny little delicately woven nests in it. Nests on three stalks, that ought to fall down, but don't! All twittering and chattering, preparatory to going to sleep. The quail that have been kicked up all day on the march are finishing their incessant plaintive whistle. The sandgrouse are flighting to the water with their peculiar hoarse, croaking note, and a few herds of oryx and zebra and Grant are grazing, happily unconscious of the near proximity of human beings, although a solitary ostrich or two further off have their heads up, as if not quite satisfied with everything!

One takes the scene all in at a glance. One thinks of the sky or of one of the objects of the earth, and thence follows one's sequence of thoughts. Details, as they seem, give rise to different thoughts-sport, shooting, fishing, the heat, the snow, India, the Himalayas, things and 


\section{Big Game Shooting}

places that one has seen before, people that one has known in them, faces, and then suddenly Africa! Africa in all its intensity. Back to the country one lives in at the moment.

One may well ask, "What is there in Africa that is so fascinating?" It is a question that I have often been asked and have asked. No one has yet given me an adequate answer. I say "The peace of Africa!" but what it means I cannot tell. Let me live in the African wilds for absolute enjoyment, content, and peace. I wish little more!

I thought I had made a mistake when Kilimanjaro told me of strife and turmoil in the midst of this quiet, till the harsh notes of a bugle behind clanged out "retreat." I returned to realities with a start, climbed up, and was face to face again with actual life, its worries, and its routine.

At the base of the rock are dotted the tents of the soldiers and porters, dirty with hard use in the rains. Little fires gleam haphazard below, and the blue smoke filters slowly upwards and blurs the scene, whilst the camp hums with the talk of men and porters lying lazily round their fires. A belated figure or two is hurrying in with a load of firewood, collected off the plain, only he himself knows whence. Another man shortly appears, like a Christmas tree, laden with countless water-bottles, and bending down with their 


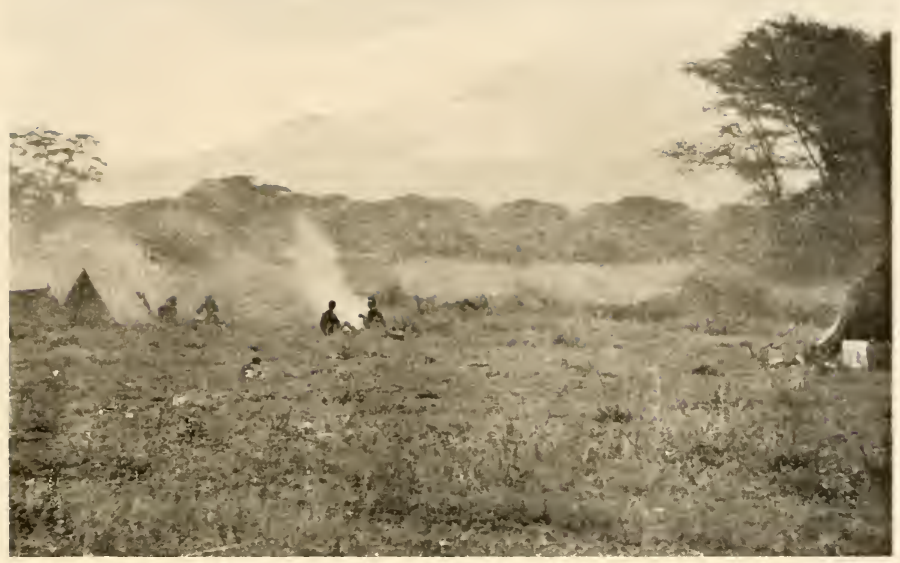

KIIIMANJARO BEFORE SUNSET

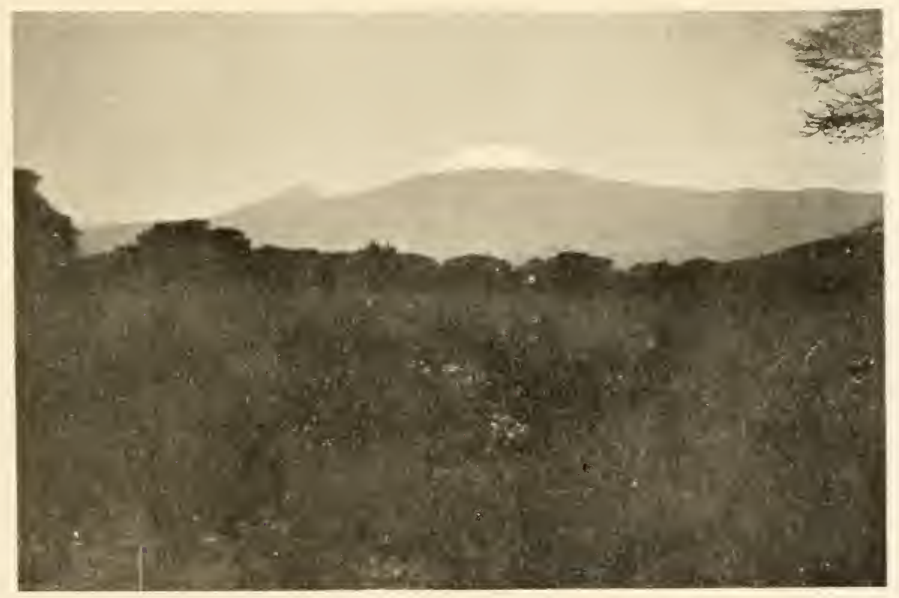

KILIMANIARO AT MIDNIGHT

(This was exposed for 25 minutes) 



\section{An Impression}

weight. He has been in his turn to fetch his comrades their water this evening. Horrid red legs and ribs of freshly killed meat, shot on this morning's march, are being divided up amongst all and sundry. The usual couple of porters are having a fight over a piece of what will be converted into tripe (without the onions!). My "guide, philosopher, and friend," in the shape of a savage Masai, comes and takes his spear with my little Union Jack on it, and puts it inside my tent, safe from the dew. My orderlies are rushing about packing up heads and skins that have been put out as usual to dry in the sun all day. The cook looks slightly worried, and the boy is standing ready with a change of shoes and socks.

The guard has fallen in by the camp fire, and the bugles are sounding the "assembly." The soldiers fall in, are called to "attention" and stood "at ease." The colour-sergeant arrives and gives his report; matters for the morrow's march are settled; sick men seen and attended to ; the headmen of the porters have their orders issued to them; and master retires to write this "Impression" with the aid of a lamp and a whisky and soda.

Shall I ever go to Africa again? Please don't bet about it! Go yourself and see what you think! Leave the shady side of Pall Mall and bury yourself in space, and peace, and Africa as 


\section{Big Game Shooting}

I have seen it. They are synonymous! In the heart of the forest, on the vast open plains, one is alone with Nature. I have heard it said that it turns one into a barbarian. I am afraid I don't agree. Sorry! But Nature is there, everywhere, and alive in all her glory. Leave shooting alone! What remains? Walk about and look, and there are the birds, the beasts, the insects, and the flowers! What more can one want? Study them. What do they do? How do they live? It is part of the programme of every man's life to look into these seemingly small details. Look into them, and it will be seen, I think, fairly clearly how it behoves one to live.

Have a try, and you will not be any the worse for having been in a lovely, lonely land and leading a wholesome life, useful to yourself and also to your fellow-creatures.

I could transport you to a view over the Athi Plains, from a certain tree where I found the peace-the only peace-I never had before; in the golden sunlight, in its fading glories, in the twilight!

I lived and loved it, and loved to the uttermost!

But I have said enough - not being a novelist. 


\section{WAYS AND MEANS}

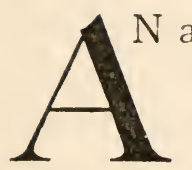

$\mathrm{N}$ account of the various shooting-grounds and districts, together with what game may be expected to be met with, as well as the best way of getting there, may be useful, and also of interest.

If I had to start off again I should, on landing at Mombasa, spend as little time as possible there, for the following reasons: the heat is always steamy and feverish, and there is little or nothing to be done by the sportsman who is probably keen and eager to be off into the wilds. Two days ought to suffice for the landing of one's rifles and dutiable impedimenta, and getting them through the customs, besides the shooting licence and the engaging of a personal body servant.

Then take the train and rattle up to Nairobi, where one makes up one's caravan, buys stores, etc., signs on the porters, gun-bearers, and headmen, and last, but not least, gets advice and tips about the country in general. Nairobi is also a very good central position from which to make a start. It is a very sound thing, if the sportsman intends making so long a stay as four to six months shooting in the country, to spend five days 


\section{Big Game Shooting}

wandering round the Athi Plains as a trial tripfirstly, to see how one's caravan shakes down and find out what one has forgotten; and, secondly, after lions, which are on the warpath in large quantities, pursuing the innumerable large herds of game collected here.

The south of the railway is a game reserve right up to the German boundary, extending along the railway from somewhere near Mount $\mathrm{Kijabi}$, at the edge of the Great Rift Valley, on the Kikuyu escarpment, as far down as Tsavo Station, where the Tsavo River makes the southern boundary to Kilimanjaro. So this side of the railway is barred, as well as a half-mile strip along the northern side.

A good trip for the above-mentioned purposes would be to march one's porters down by the side of the railway, cross the Athi River near the station, and proceed to Stony Athi. One could follow by train the next day, having got permission to stop the train at Stony Athi, as the station there has been done away with. The reed beds there usually harbour a lion, if not two. After which make a bee-line for Lucania, near the hills bounding the Athi Plains towards Machakos. Thence follow along the foot of the hills by Koma Rock, which rises out of the plain by itself and cannot be mistaken, camping there en route to Donyo Sabuk, where one can cross the Athi River, near the falls, and so back to 


\section{Ways and Means}

Nairobi; preferably over the plains, as it is shorter, or by the Fort Hall road, through the Kikuyu Forest, past all the settlers' houses, which is a very pretty, though roundabout, way. The plain is full of lion, as well as Coke's hartebeest, zebra, Grant's and Thomson's gazelle, with every chance of a rhino, and possibly a small waterbuck, not worth shooting, on the last two days. As a matter of fact Coke's hartebeest heads hardly seem to vary at all in size anywhere, but Grant's and Thomson's gazelles are smallish here, and the animals are very wild, as this is a very favourite trip for shooting parties, and lots of animals are shot at, particularly in the case of the latter, so as to get them off one's hands, and not have to bother about them later, when rarer and bigger game are on foot.

I would strongly recommend this as a trial trip for the reasons I gave before, as on reaching Nairobi after this short time lots of porters can be got rid of and replaced. It will be found that several are constitutionally weak, lots will have gone sick, and others will have had a scrimmage with their headman, and so will have to be drafted out as nuisances. On a long "safari," as it is called, everything ought to go like clockwork, and there should be no interference with the authority of the headman on any consideration whatever. It also gives the porters an opportunity of getting to know their master. They 


\section{Big Game Shooting}

are only so many children, and the old maxim, "Anything for a quiet life," is fully borne out here. One thing more: the aim and object of the shooting party will probably be a trip to Lake Baringo or, shorter, to the Tana River. At any rate, there are good places to pick out at first, preferably the former. Starting on that supposition, the porters who would have been engaged before the trial trip above-mentioned would have to be suited to these districts. For this reason the local porters to be obtained in Nairobi are excellent-i.e. Wanyamwezi from beyond Lake Victoria, who have carried loads half their lives, and will go on doing so till the end of the chapter-with a large proportion of Wakikuyu as well. The prefix "wa," I may mention, denotes the plural of a "person," and therefore, in most cases, the whole tribe. Wakikuyu are wild, but first-rate and cheap into the bargain, and the fact of their being engaged to go somewhere near their own country, and not to a far land, will keep them happy and contented.

We will take the trip to Lake Baringo first. Pack them all in the train and take your tickets for Nakuru, and on arrival, after about a ten hours' journey, during which the scenery is magnificent, pitch camp for your entourage close by the railway, and repair yourself to dine and sleep in the Station Dâk Bungalow. The first day's march is round the Menengai crater-which 


\section{Ways and Means}

is now extinct, but full of big rhino and more or less inaccessible-leaving it on one's left. The herds of hartebeest seen dotting the plains here should be violently pursued, and with infinite care, as this is one of the few places one comes across Neumann's hartebeest; so they should not be missed, especially as one loses them altogether two days' march ahead, and Jackson's variety takes their place. The second day one will camp near a large marsh-I forget its name, but it cannot be mistaken, as one can see a broad expanse of water and reeds on the left, not far from the Molo River. It is worth trying in the evening for a big water-buck. The following day Lake Solai will be reached, and a day's stay here will be amply repaid by a go at duck and snipe, to replenish the larder with some toothsome morsels, and Jackson's hartebeest into the bargain. This valley, I believe, is now very much settled, but that should not make any difference to speak of with regard to shooting on the high road to Baringo, which this is.

From here there are two routes onward: one on the left of the valley past Lake Hannington, which is full of flamingoes, and stinks for miles around, presumably on account of the droppings of these birds; and the other on the right, or east of the valley. I recommend the latter, as there is very much less traffic this way, and consequently game is more plentiful, whilst on 


\section{Big Game Shooting}

passing under the foothills of the Laikipia plateau, along the River Rongai, are rhino, a few buffalo, and herds of Jackson's hartebeest. I do not fancy that game preponderates in anything like the quantity by the other route that it does here.

And so on to Baringo, about three days away, with Laikipia overhanging this line of march on the right, and the Kamasia Hills and Elgeyo escarpment farther off in the distance on the west.

Baringo is a curious lake, full of hippos and crocodiles. They say that the latter are not man-eaters, and from all accounts that appears to be true, but at the same time I wouldn't care to give sixpence for myself if I tumbled in, although I believe it is correct that there are very few cases known of the women or children being killed by them. A great point of interest is a tiny rocky island near this end of the lake, on which there is a boiling spring, showing that the lake, which is in the Great Rift Valley, of course, still bears evidence to present volcanic action. Mount Andrew on Lake Rudolph, farther north, is still in action, and Mount Ebueru, close to Gilgil Station on the railway overlooking Lake Naivasha, although it does not erupt, spurts steam from twenty or thirty different fissures along its base, quite close to the railway, just like the safety-valve of an engine. In the 


\section{Ways and Means}

hot spring on this island in the lake it is quite possible to boil an egg, or a fish fresh from the lake.

The native town of Njemps is close by ; here supplies can be obtained for one's caravan, and this is a very good centre to sit down and shoot from. If the time of the year is right, and the surrounding country is covered with grass, the district will swarm with game of all sorts : giraffe, oryx beisa, Grant's (in small quantities), Thomson's, and Peters's gazelle, the zebra "of commerce" (which one will have got a horror of by this time, owing to the caddish way in which they alarm other animals), rhino, and up in the Laikipia Hills is one of the only haunts of the greater kudu in East Africa. Elephant pass this way as well, in their half-yearly wanderings from Laikipia to the Elgeyo escarpment on their journey to Mount Elgon farther west.

Stay for a good fortnight and shoot from this spot, making two and three day marches from it. Lion are also to be found here, as they had been all the way up from Nakuru, the startingpoint.

One must return by the same road at the end of this trip, as the Nandi forests on the west are devoid of game, and the Laikipia plateau is now a reserve; but in any case the march across Laikipia is a hazardous undertaking, except in the rains, on account of the water question. 


\section{Big Game Shooting}

There is little or none to be found on the way, and even then the natives don't at all fancy crossing in large numbers because of the shortage of this necessity to existence: There is not much game into the bargain up above, and one will get better shooting back the same way.

Once having reached the railway again, and having had another try at Neumann's hartebeest, near Nakuru, one might stop at Lake Elementeita and go to Camp Mbaruk for impalah and waterbuck, by way of varying the monotony and breaking the railway journey on the way back to Nairobi. There are also Grant's and Thomson's gazelle in any quantity, but the whole place has been so tremendously shot over, almost as much as the Athi Plains, because it is so easy of access, that I do not recommend it as a shootingground. It is easy shooting, in a way, as the game is at your front door, so to speak, but hard because of their timidity and shyness on an open plain, and after all one has probably got these animals before, and will not want to waste time.

Farther down the railway again, first-rate duck and snipe shooting can be got on Lake Naivasha if one cares to stop for it, as well as guinea-fowl on Crescent Island, on the lake, if permission can be obtained from the owner; as well as a problematical chance at a hippo from the aforesaid island, or at the western end of the lake. There are, too, some very big Grant's gazelles 


\section{Ways and Means}

on the Endabibi Plain far round on the western side, but this means a probable five days' outing.

If one does stay at Naivasha, a day at the Government zebra farm is well worth it. One might spend much time going farther and faring very much worse.

In any case, whether one stays at any of these places or not, a return to Nairobi is almost necessary to pay off porters, reduce their numbers, or probably to lay in a fresh store of food for one's own consumption into the bargain.

We will now take the other trip in the same sort of direction, north, from Nairobi to the Tana River. The best way to start is by the road, or rather path (all high roads, as they are called in East Africa, dwindle down to a mere path, at times very difficult to make out and follow, some of them simply game-tracks across the plains, through the high grass, round bushes and trees and mounds; but they are the means of connection between two distant places for all that), by which our friend came into Nairobi from the trial trip across the Athi Plains.

Instead of going as far as the Athi River Falls, branch off to the left to the Thika Thika River, cross it, and camp on the other side. The crossing is effected by means of a seat travelling on a wire hawser stretched across the river.

It was intended to build a bridge over it, but that had hung fire, and the hawser from bank to 


\section{Big Game Shooting}

bank, tied on to the piers on each side, was for use in hauling across the baulks of timber to build the main roadway upon. The river swarms with crocodiles, so that if the rope broke one would be hurled through twenty feet of space into water and the probable jaws of a gaping crocodile. No unmixed blessing! The camp should be pitched on the western side to avoid the ticks and jiggers of innumerable native caravans passing that way, who always choose the friendly shade of the big trees on the hither side and hope for the best as regards insect life. A water-buck or impalah-I saw a very big one there oncewill be sufficient reward for that evening's stroll, or, if one is unsuccessful, a succulent Grant's or Tommy's steak shot on the way, in the morning, will still come in useful. By the way, this stage will have to be undertaken in two marches, as it is about thirty-two miles. A short march of ten or twelve miles will suffice the first day, as there is always a lot of bother on one's first day's trek out of any standing camp, be it in a town or in the wilds. The next day, starting early, one wanders through rather monotonous rolling country, with the usual common game, and an occasional sight of a giraffe, to Punda Millia. There are lion there, but not many, and they tell me that there is a herd of roan in the neighbourhood to the north, but not worth going for. I can locate a herd in another place later on. On the follow- 


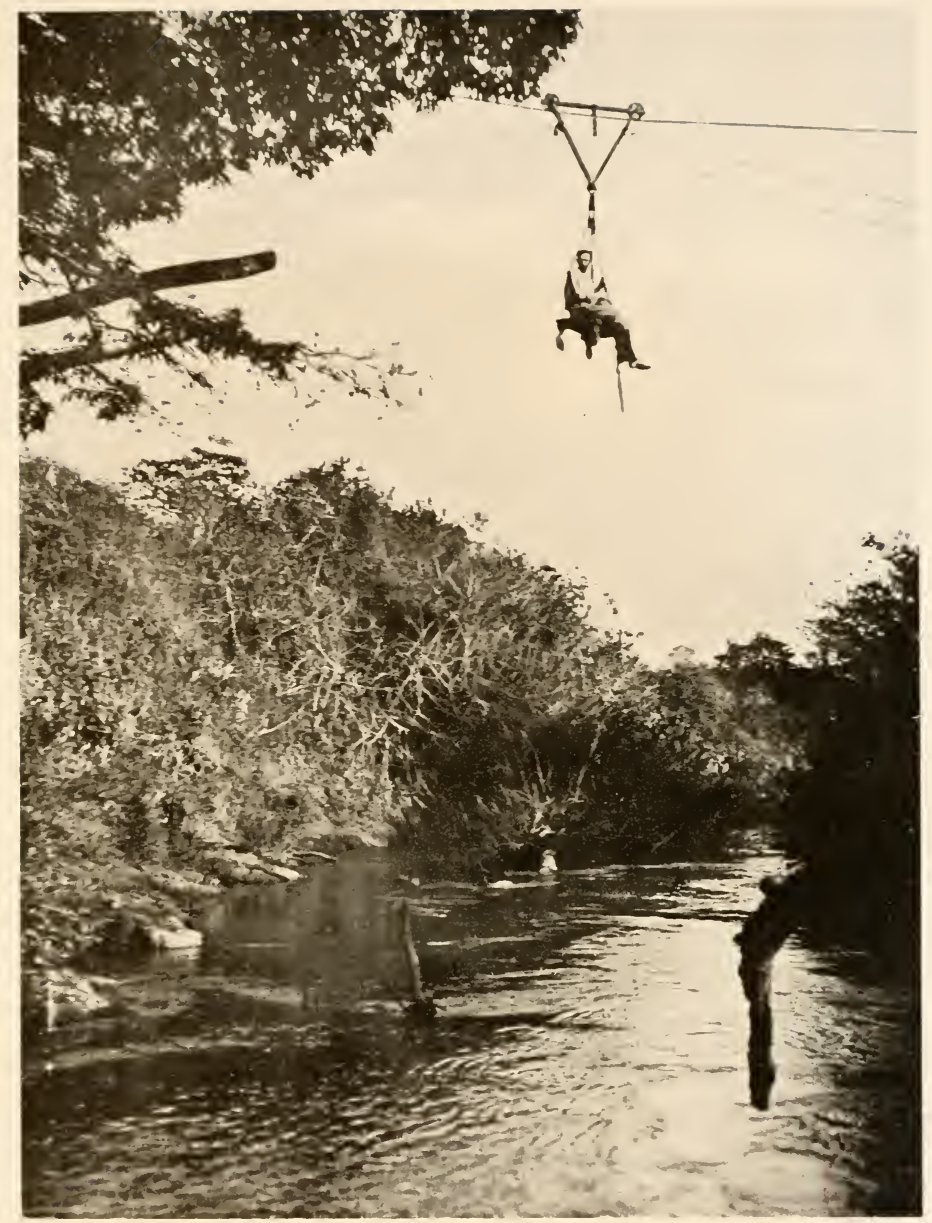

THE SWING BRIDGE AT THIKA-THIKA RIVER 



\section{Ways and Means}

ing day a pretty march, crossing rivers with primitive creeper bridges, more especially the Maragua River, up hill and down dale one arrives at Fort Hall, a fort with a collection of Kikuyu mud-huts around it, and the whole countryside covered with maize and matama (a species of millet), situated on the top of a hill, over the Mathioya River, a stream which supplies the community at large with water, ice-cold, from Mount Kinangop, of the Aberdare range, and a splendid view of the snow-clad peak of Kenia to the north. Many and many a happy day I spent there in the comfortable house belonging to the Sub-Commissioner of the province. We wandered about riding, shooting Chanler's reed-buck, and fishing, and then sitting by the river, under the shade of the fort perched above, smoking, and talking about everything and nothing in particular. However!

This is a place where one can replenish with supplies for the caravan, so it is a good thing to start one's porters quite light at Nairobi, with enough food to carry them through to Fort Hall, as food for the porters-matama, beans, and sweet potatoes-can be bought in any quantity here cheaper than at Nairobi, sixty-five miles away.

When "Richard is himself again" away we go, descending the hills to the banks of the Tana, the porters, full of food, all happy at their stay in what they are pleased to call a town, the Wakikuyu community in particular singing and 


\section{Big Game Shooting}

jingling their anklets rhythmically and regularly like one man as they move to our first camp, where the Maragua River joins the Tana, moving east now, which we shall go on doing for a week or so. A photograph or two of the ford over this river, accompanied by a picnic there, is all that is worth staying for, and the next day will find one in a beautiful game country: the Tana on the one hand, with grassy slopes studded with the ubiquitous thorn bush on the right, up to the hills above, dotted with herds of impalah and water-buck, down once more to the river, which is stiff with crocodiles of all sizes, along the valley we go, with every now and again a rhino showing its ugly self (and there are plenty of them there), to camp after camp. It is worth while going easy down here, always supposing that one is not pushed for time.

It is warm and nice, there is game in plenty and to spare, so one soon learns here to let animals off, to discriminate between the signs and lengths of various bucks' horns. Whilst the caravan moves slowly onwards, some ten miles at a march or so at most, one scours the country on the right bank of the river down which one is shooting twice a day. That is the proper way to do things, as different animals feed over the same ground in the evening compared to the morning. At length one reaches the main up-country affluent of the Tana, the Thika Thika River, 


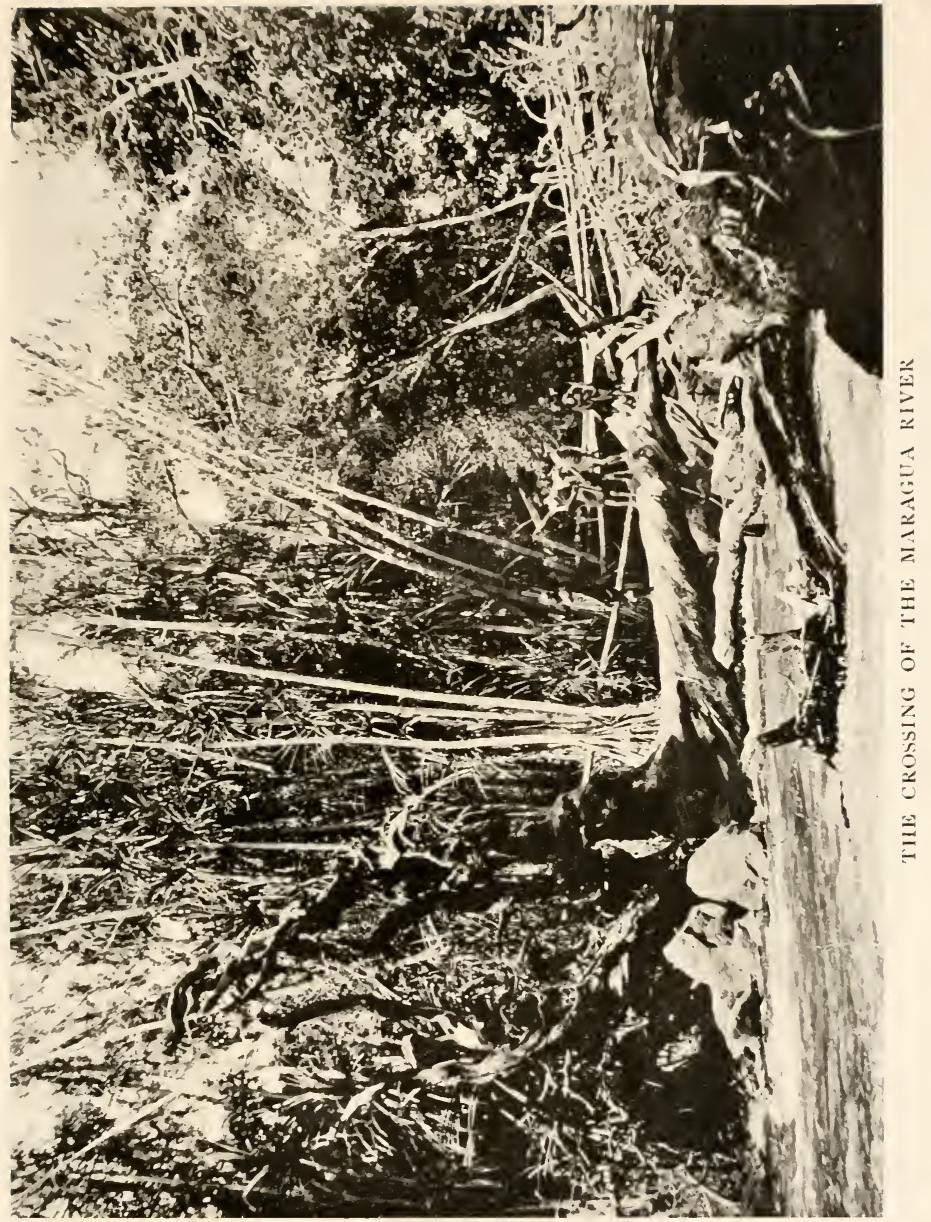





\section{Ways and Means}

which we crossed higher up on the way here in the swing-bridge. Here we come to Hippoland. There is a small herd in the big pools of the Tana here, but when shot they are hard to get out, as the banks are so steep. Here I counted five rhino one morning, when sitting on the bluff where the camp was pitched over the river, eating my "chota hazri," as it is called in India. There are buffalo, too, in the thick bush by the riverside. Quite recently a fine head was picked up by a friend in this neighbourhood, close by the skull of a lion, evidently showing that there had been a battle royal between the two, and that both had succumbed to their efforts.

From this point one has the choice of two routes: one rather farther afield, on to Kitui, and thence to Nairobi, the other round the hills to the right, making one's way by Donyo Sabuk to Nairobi. I doubt if the former will repay the sportsman to any very great degree, and it is somewhere on the latter road that an American friend shot the second-best eland. This species will be found, I think, in only small quantities hereabouts, so I should, on the whole, recommend a return to Nairobi by the latter route, to try and pick one up, added to which he will have more time to spare afterwards for another trip.

Food for the porters will have to be carried as far as Kitui on the first route, as one can buy more there, but about the same amount for the 


\section{Big Game Shooting}

journey back to Nairobi as would take him to Kitui by the latter route.

"We haven't got much money, but we do see life!" is a good old saying which appeals to most of us. The man who invented that ought to have been knighted for his pains! Apropos of this, a cheap trip, which is well worth taking, is up the railway to Mohoroni Station, on the borderland between the Nandi and Lumbwa countries, and about twenty-five or thirty miles from Kisumu (Port Florence) on the lake.

One wants no porters at all for this, and with luck one ought to get the two species one goes for well inside a week. One is roan antelope, which is a practical certainty there, and the other the topi. It is rather a pity to leave the country without having a try for either, as they are easily obtainable by the laziest man in the kingdom. One gets out of the train and lives in the Station Dâk Bungalow, which is very comfortable indeed, and frequented in the evening by possibly one or two settlers who drop in to hear the news. One has a good dinner and a chat with any one there. They are delighted to meet a new acquaintance, to pick up any news about the outside world, as they have been in comparative exile for months, slaving on their farms, and continually worried by Nandi raiders. They are real good fellows, and will do anything to help one. Imagine yourself tucked away and more or less forgotten! 


\section{Ways and Means}

Wouldn't you put yourself out of the way to hear all about old scenes? Tattersall's! Church parade in the Park! The theatres! And the Savoy to top up with!

Well, next morning you tumble out at the first streak of dawn, as this is a lower altitude than you have yet struck since Mombasa, and it is very apt to get unpleasantly hot and steamy in this sort of saucer in the hills. All you have brought with you is one gun-bearer and one body servant-the latter tidies up your room and proceeds to have a good time in the bazaar (a tiny one, but a bazaar all the same from his point of view), and the former, having been warned beforehand, has collected two or three tame Nandi as guides, who do not mind shouldering a leg or forequarter-the Nandi won't all do it-and away you go. Along the railway towards the lake, over a wooden bridge, stepping from sleeper to sleeper, and not looking down, as it is all openwork and there is nothing between you and the abyss below, till, reaching terra firma again, you strike off to the right or north. I spent a Christmas there, during a row with the Nandi, and on the $25^{\text {th }}$ December shot my first roan: nothing out-of-the-way large-still it was a most acceptable Christmas present.

That was after the short or autumn rains. The grass was long, and one got drenched with dew half-way up one's thigh on the way up to the 


\section{Big Game Shooting}

unmistakable mound, a landmark on the rolling plain, which stretched as far as the lake on the northern side of the railway, under the forest-clad precipices of the Nandi Hills.. As regards walking the country is rather difficult, as in the bottoms between the rises, narrow, muddy, bushed-up rivulets, with steep banks, run towards the "Cloaca Maxima" of the district, the Nyando River; and the steaming heat makes any exertion rather trying. The place is rather like a huge apple-garden, as the thorn trees in this part of the world are about the same size as apple trees and very much like them in appearance, there being no thick jungle of them. For game, one ought to make for this mound, and once on the top use one's glasses to find roan, topi, or Jackson.

The roan, I fancy, rather affect a low range of hills to one's right front of the line one has been marching on, but after having gone some eight miles or so leave them alone, if none have been seen up till then, till next morning, and have another try then. Devote your energies, making a wide sweep towards the railway on your return journey, to topi, which you have not met yet. One or the other you are bound to get in the first day's outing, and, as I say, both can be guaranteed inside of a week.

This may be called shooting at one's front door with a vengeance, as both these animals being met with so close to partial civilization, with none 


\section{Ways and Means}

of the expense connected with a camp and porters, and no trouble with either into the bargain, together with the fact of the almost certainty of bagging both species, is worth the comparative rest and ease and the slight expense incurred in doing so.

There is also another animal to be met with in the district. At the next station up the line towards the Lake, Kibigori, there is a very wellknown herd of elephants, which seem to haunt the place. They have been tremendously shot at, however, and consequently are very savage and vicious when met with, and the fact of several having been bagged out of the herd from time to time recently, makes it doubtful if they are worth while trying for, as there may only be cows, which are barred, in the herd, together with young males, which it is a shame to shoot. The country is open, covered with long grass, and orchard-like in appearance. It is necessary to obtain information from the station-master at Kibigori as to the whereabouts of the herd, and if they are some way off it may be waste of time trying for them.

A spare day at Mohoroni may very well be spent in a five-mile climb to Soba, a civil station perched up on a lower spur of the Nandi escarpment. It makes one a bit heated, to say the least of it, but the view is great. To the west the lake shimmers in the distance; in front are the Lumbwa Hills, in the comparative foreground, beyond 


\section{Big Game Shooting}

Mohoroni Station, with the Kisi or Kassova country rising above them, far away beyond the Nyando River; a train may be leaving its thin white trail of smoke on its. way through the Lumbwa and Sotik country towards the coast; whilst at one's back, peak above peak, covered with dense forest, rise the Nandi Hills, frowning over the peaceful valley, and resounding from hilltop to hill-top with the echoes of the wild-looking inhabitants, armed to the teeth on all occasions, passing the news from one to the other throughout the country. It is wonderful how this news travels. It may have to do with warfare, or the more peaceful occupations of their wives and families. It is one of the features of the country.

Apropos of the natives in this corner of the globe, a story is well worth telling of the tribe who inhabit the country round Kibigori and the east side of the lake, called Kavirondo. They, one and all, go about quite happy with not a shred of clothing adorning their bodies. One fine day a good lady, fresh from England, was going up to Uganda, and being horrified at the sight of these indecorous savages, stopped at Kisumu, the terminus on the lake, and purchased yards upon yards of the local cloth-merikani-which was sent down to the headmen in touch with the railway and the semi-civilization of those parts, for distribution to the local ladies of fashion. What was her disgust, on her return from a short stay 


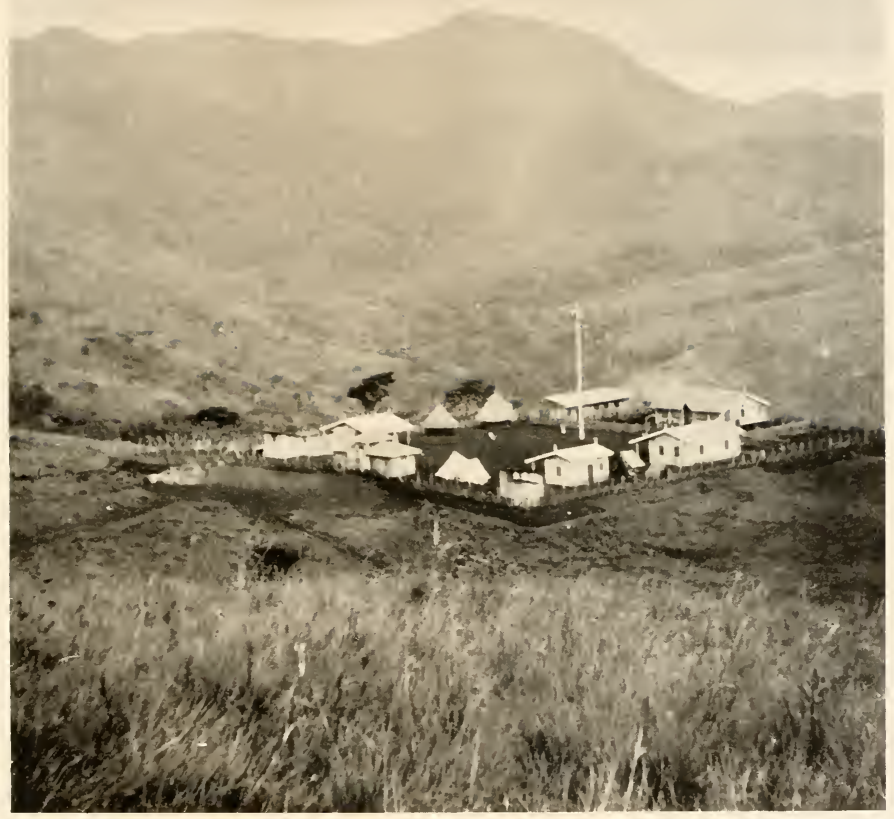

SOBA STATION IN THE NANDI HILIS 



\section{Ways and Means}

at Entebbe, to find these dusky belles still minus the conventional fig-leaf, and the husbands each wearing the strip of nice, clean, white merikani as a turban round their heads. She gave it up! That, I believe, is an absolute fact.

Another part of the country now claims our attention as a shooting-ground, and one well worth going to, but it will take more time and trouble than any of the former localities. That is round Kilimanjaro, and up the German boundary to Lake Natron. This expedition entails more expense as well, but considering the quantity of game, and the different varieties to be met with en route, it is worth the whole lot put together. One should provide oneself with a German licence to shoot in their territory, however, as, after leaving Kilimanjaro, British territory is barred, owing to its being a reserve. This is easily done, and it is inexpensive. One should engage one's porters at Mombasa, if it is found impossible to obtain anyat VoiStation, where one leaves the railway. This information can be obtained by writing to the official at Voi, who will tell you whether or not any porters are offering their services at the time. They will probably be Wateita if there are any, and they aren't bad in this barren, stony country. A letter should also be written to the British collector at Taveta, on the south-eastern slopes of Kilimanjaro, to engage porters there, which can easily be accomplished. 


\section{Big Game Shooting}

The reason for this is that the journey from Voi to Taveta is almost entirely without water at the best of times, so that instead of hampering oneself with a huge caravan of porters, it is cheaper and easier to get a few at Voi, send one's baggage, food, etc., over by relays to Taveta, and make one's real start from this latter place, with porters from the countryside there, who know the district to be traversed after the waterless part has been crossed. Whilst one's impedimenta are being collected at Taveta one can spend the time most profitably in a short journey to Lake Jipé over the border, where the shooting is very good. I have not actually been there, but it is so.

On leaving the train at Voi we enter the Taru Desert, and then one's troubles begin. This merges into a district known as the Serengeti Plain after leaving the Bura Hills behind to the left. Guinea-fowl are to be met with on the first part of the journey, which takes some four days, and fringe-eared oryx in small numbers, with small buck, the last part of the journey. However, it is best not to linger on the way, but foot it hard to get it over. All the game you meet there will be seen afterwards in greater quantities. - Lake Jipé I do not know, but a trip there would be better than wasting time sitting down waiting for the arrival of two or three caravan-loads of stuff brought over by one's best and most trusted headman. A trip up to the big German military 


\section{Ways and Means}

station higher up on the slopes of the mountain, Moshi, will be well worth while. It is worth seeing, and the officers are always glad to see and make friends with parties coming to shoot in the neighbourhood. By the way, elephants are barred in the Moshi district, which extends for a long way up the boundary, in fact, as far as Lake Natron.

When everything has been brought together at Taveta, all arrangements made with the help of the collector there, details settled, and all ready, the time has come to depart. One will start through cultivated land at first, banana groves which shake and whistle in the wind, sounding like rain on the leaves outside one's tent in the evening, through fields of matama and sweet potatoes straggling over the ground haphazard. They are a cunning race of husbandmen, these dwellers on the mountain-side. Keep highish up, with the mountain towering on the left, round the lesser peak of Kibawenzi, towards the district of Laitokitok. There will not be much game so high up on the mountain-side, but the view for two or three marches will compensate one for that, and more besides. The snow-clad peak turning rosy in the evening as the sun sets, with all the world stretched beneath in shadow, the horizon to the west clear-cut beneath a sapphire African sky, and the picture framed with forest trees, makes one think a bit. And so on the next day, when 


\section{Big Game Shooting}

the dome of Kibo comes in view, with its glaciers and the bare rock below, then a strip of white rhododendrons in full blossom, like a ring on the finger of a bride; lower, the dark bluegreen of forest seen first high up in the distance, and then clothing the mountain-side nearer to one, a broad belt of forest trees and impenetrable jungle; lower still, nearer oneself, between the forest and the observer, broad emerald-green waving slopes of grass, down, down to the plain beneath, dotted with herds of game in countless numbers. This is a lovely land worth living in, worth shooting in, worth coming back to? Yes, worth anything. Africa is always calling one back. There is a something mysterious in the country. Not a day passes but one sees or hears or learns something new about the great Dark Continent. Man has held his sway there for years, but it is well-named Dark. How many are the wiser as concerns its hidden mysteries? How many are there who really know anything at all about the strange people who live there? There is an extraordinary fascination about it all. The birds say "Come back!" So do the flowers and the trees when they rustle in the evening, and the very breeze that blows one away from Mombasa when homeward-bound sighs, "Come back! Come back!"

Laitokitok once reached, one's labours can be begun. The Nyiri marshes can just be touched 


\section{Ways and Means}

for shooting purposes, as they lie south of the reserve boundary on the Tsavo River, but afterwards one must keep rather more to the left. A good point to march on is the southern end of Donyo Erok (Donyo is the Masai word for mountain). This can be seen easily from the comparatively high ground before descending to the Nyiri marshes, and the very end of it is just in German territory. Shooting on the left-hand side is safe. At any rate, another good landmark which any local Masai guide will point out is Mount Longiedo, well over in German territory. That will do to march on at present. At the far end of these marshes are several conical hills, with dreadfully long unpronounceable names, about which, I believe, we had our legs thoroughly well pu' 'ed by the local savage. One of these, which we were told was named Olotoboiologunya, really meant something to do with our caravan! Take the one nearest to Kilimanjaro, where there is a spring of fresh water, and sit down for a short time. There will be game in any quantity from the lordly eland to the sand-grouse. Some very fine bull eland live there in peace and plenty, never disturbed by the sound of a gun, and seldom by the sight of a man. Fringe-eared oryx roam about in large herds. I came across fifty at the same time once, which is unusual. The lesser kudu is there, but they are always shy and very few and far between. There are a few rhino, and 


\section{Big Game Shooting}

there is every reason to believe they are big ones, well worth shooting when met with. Ostriches are also to be seen daily, though whether they can be got at remains with the wielder of the rifle. Hartebeest, Granti, Thomsoni, zebra, giraffe, and wildebeest! Ça va sans dire! "The poor we have always with us!"

After two or three days carry on. Remember food supplies are not to be obtained in front, and we must not wait too long in any one place till we know where we are and how we stand towards the end of our journey. We shall have to retrace our steps on pretty nearly the same route. So, having spied out the land, and where different species are to be found, we shall meet them all again later on our return journey. The next day one crosses either a large shallow marsh or what would be one in the rains. It depends on the time of year when one passes. When I was there in April it was more than knee-deep and about two miles broad, and the duck were there in swarms. A morning after big game, with a good evening shooting duck to follow, is all a man wants, and my friend and I enjoyed it to the backbone. A good camp will be found here, somewhere close at hand, the landmark being two large, strange outcrops of granite rocks sticking up out of the plain, and the left-hand one of the lot is the one to make for. We christened it "Whisky Camp," as we found, to our great 


\section{Ways and Means}

delight, on reaching it, a case of whisky, kindly left by our forerunners on the Anglo-German Boundary Commission, after we had been out of that commodity for a fortnight. I remember very well he shot a succulent Tommy, and I shot an ostrich, while we both had a good evening at sand-grouse in honour of the occasion. Then comes two days of rather monotonous trek, in rather than over grass, through the Matambatu country of the Masai.

I may mention that the Masai are very splendid fellows, born cattle-fanciers, and the old-time terror of the countryside for miles and miles around. They are still cattle-fanciers, and hard to beat at that, though their fighting propensities have died out somewhat, at least as regards terrorism. The enlisted company in the local regiment at Nairobi is, I protest, second to none, and they were jolly good fellows into the bargain, and quite the best friends in the savage line I've ever struck or hope to meet in this amazing world of ours. The tribe, as a whole, has been divided up into sub-tribes, who have certain districts given them, allotted in the old days by their one and only chief Mbatien, who, now he is dead, is revered by one and all as a god. It is their boast, and I believe perfectly true, that not one single order or command of his was ever disobeyed. That is extraordinary, if one knows the savage mind, and it shows to what a tremendous 


\section{Big Game Shooting}

pitch of organization this tribe arrived at. They are still regularly drilled in companies sixty strong, called "ip," in spite of the famine which did a lot to wipe them off the face of the earth some ten years ago. They are Nature's gentlemen, every one, if ever I saw one! Well, the various subdivisions of the one great tribe were allotted different grazing grounds for their cattle in the old days, and we are now passing through one of the biggest of the lot, the Matambatu country. Round Lanjoro Dis, which we shall reach in another two or three marches, comes the Kikinyuki district, and then in the Rift Valley, behind Nairobi and the Ngongo Bagas Hills, lies the Dogolani Plain. There are several others, but we shall not enter their domains.

If one marches on Donyo Erok so as just to miss it there are good camping grounds, with plenty of good water, at the very foot of the hill, and on the way thither one might have seen, if not shot, oryx callotis, eland, wildebeest, probably singly, and Coke's hartebeest, zebra, Granti, Thomsoni, and ostrich. This march is not worth while wasting time over. On reaching Donyo Erok, I should make a division in my caravan. This is to save expense. I should send back as large a proportion of porters as possible, with their bare rations for the return journey minus one day's food-as they will get that on their arrival at Taveta-to fetch up more 


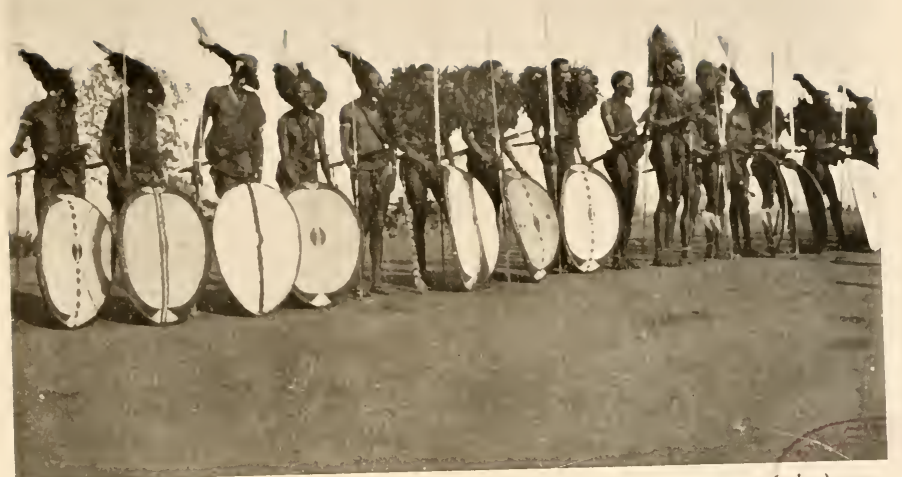

MASAI SPEARMEN SHOWING THE IDFFERENT COSTUMES (sic.)

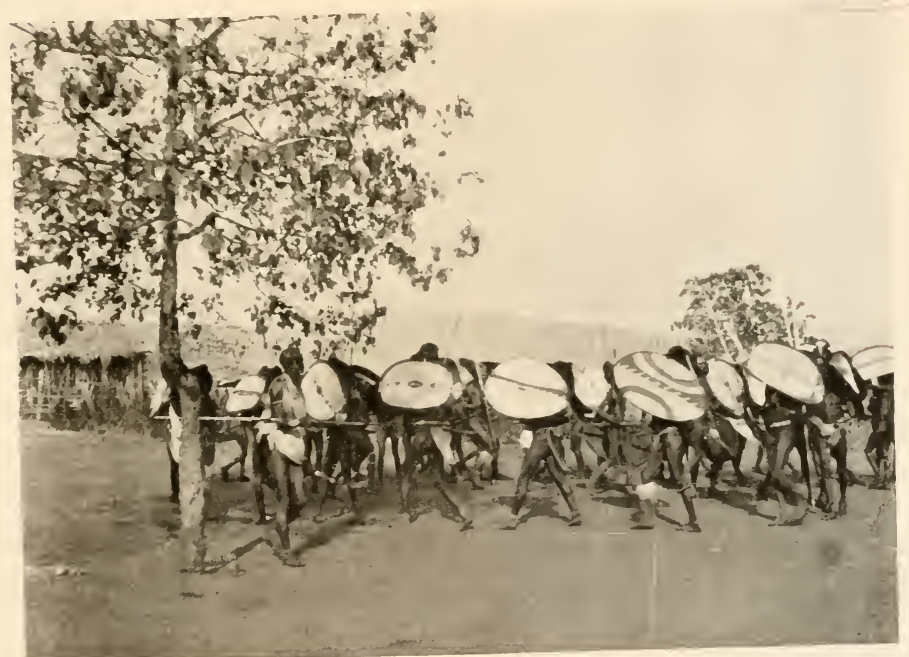

A MASAI WAR DANCE 



\section{Ways and Means}

stuff here, so as to meet them on one's return with supplies for the trek back. I should then load up all the remaining porters with all they can carry for a dash beyond Lake Natron, which, however, has been one's aim and object. They should be made to understand in the beginning that if rations are likely to go short on a serious trek, any animal one kills will be equally and fairly divided out as food for the lot of them, and a small proportion of matama or beans cut from their rations, so as to save food for a rainy day. They will at once agree, as they love meat.

Go hard for Lanjoro Dis, a spring on the side of a hill, Mount Kilibei, two good days ahead, with not much game to impede your progress in the interval except the common zebra and Grant in any quantity. I met a lion here as a matter of fact. The spring is in German territory, and one has a magnificent view from here over Lake Natron at one's feet to Mount N'gai at the south end, and Mount Sambu opposite; the Rift Valley dividing you from this continuation of the Mau escarpment that you met before perhaps overlooking Naivasha and Nakuru. On the way down the watercourse from Lanjoro Dis towards the bottom is first-rate lesser kudu ground, and a day might be well spent at the bottom, some seven miles from last night's camp, shooting well to the left so as to keep in German territory. You will want a Wandorrobo guide for this part 


\section{Big Game Shooting}

of the march, to show you where water is to be found. On leaving the camp under the hill it is best to go hard, of course shooting oryx, if you come across one with a big enough head, on the way - and there are plenty there-to a craggy hill, Shombole, at the north end of Lake Natron, which is unmistakable. The lower left-hand slope is all right, and for the last five miles before reaching it oryx callotis, eland, and the rare Waller's gazelle, the latter in considerable numbers, will be met with, and it is to be hoped taken on in single combat.

Lake Natron is a soda lake, and the water quite undrinkable, but the aforesaid Wandorrobo guide will make that all right by leading you to a spring near the foot of the mountain. Once there, sit down for as long as food will last, and shoot the above-mentioned animals, as well as wildebeest, in large herds, rhino, buffalo in the reed-beds round the lake in quantities, waterbuck (big ones), ostrich, and the commoner animals if necessary, bohor reed-buck, impalah, and giraffe, if you care to. If it can be managed, go farther afield, quite high, and scale the heights of Sambu to Ndesegara, or as near it as possible on the top to try for roan, which abound in large herds; but it is most probable that food is becoming a serious question by this time, and it will be all one can do to get back to Erok and the plenteous supply which you hope and trust will be there to meet you. 


\section{Ways and Means}

On the return journey, one having spied out the land, as I said before, one can choose one's own route, but I should recommend retracing one's steps to Lanjoro Dis in any case, as one gets another chance at one of the problematical lesser kudu, which are so few and far between, so shy, and so hard to meet. Mind, this whole trek is certain to be a hard one, and more expensive than any of the others; but it will be found hard to beat anywhere in the Protectorate, and if one can carry it through, it should be a very big feather in one's cap. The northern slopes of Kilimanjaro will have furnished good sport. Below Lanjoro Dis one will have met with a shy and rare animal, and on the shores of Lake Natron the climax will have been reached in the shape of buffalo. Of course, all this is from a more or less economical point of view, that is, to avoid a useless expenditure of vast sums of money when it can possibly be got over by playing round such corners as the splitting up of one's caravan to make a food depôt for the return journey, so as to enable one to travel further at the least possible cost. Arrived at Erok on the way back, one sees the highest mountain in Africa from a new aspect. I have tried my hardest to go into a sort of ecstasy over this elsewhere. I will not repeat it, but all I say is-go and see. Perfectly wonderful!

From here a "divarsion," as the Irish have it, may be made in one's return journey. It is 


\section{Big Game Shooting}

worth while thinking over, as instead of the long trek back to the railway at Voi viâ Taveta once more, one can reach Kiu Station in five days through the reserve, but full of the most truculent rhino to be found anywhere. And there are plenty of them! March north, skirting the foot of Erok, to the Elemobarasha Hills, and thence any Masai guide will lead you to the railway. But you will find the rhino a considerable nuisance. I met several, and had to stand on guard over them till the whole caravan had passed, in case they took it into their heads to make a bolt for the caravan; and even then I once heard a bang from a rifle in front, which meant that another was making his presence felt. So close as that ! They fairly swarmed-so much so that two miles from the station I saw three, two old ones and a young 'un, not more than three-quarters of a mile away. If this latter march is decided upon to get back to civilization once more, the food supply will be largely affected, as it may enable one to go further afield in the first place, and save rations and therefore expense secondly, and one might very well spend a profitable week in the neighbourhood before returning. This last trek to Kiu should only be attempted in order to stay longer on the shooting ground, as one can only shoot a rhino on the way in strict self-defence. Don't cut down things too fine, however, as one is almost sure to regret it when one has reached 


\section{Ways and Means}

one's furthest possible camp and can't stop there.

A wanderer in a strange savage land-Africa. Whether the red blood of youth runs hottest in one's veins in the quiet of an African swamp after a charging buffalo, or the roar of the ring on the English racecourse, or the excitement and dash of the Indian polo-ground when the ponies' hoofs fairly rattle, is a moot point. Slowly but surely the Dark Continent calls one back in the stillness of the night. 


\section{ROUND LAKE NATRON}

7. AWOKE with a start. What on earth is that? Somebody has got into my house! "Bwana! bwana!" (Master! master!). "Oh, it's only you, you brute!"

Overnight my friend and I had given orders to be called in heaps of time to get out early to have a try towards the swampy ground round Lake Natron-which is nine-tenths in German territory and the remaining one-tenth in British East Africa-for a big water-buck, which we had seen several times before when proceeding towards the swamp at the first streak of dawn intent on buffalo.

It is a very sound thing in organizing a day's sport the night before for the next day to make certain agreements as to what is to be shot at. Taking the different habitats of the game into account, as well as their habits, numbers in the district or rarity on the other hand, and the hundred and one different factors that one learns on the spot, this ought invariably to be done.

For instance, a lion or lions are always allowable, so are elephants and buffalo. Other antelopes must be taken as their frequency or rarity allows. 


\section{Round Lake Natron}

But such common animals as water-buck ought to be always barred. It is useless to go out for to shoot buffalo and on the way have a bang at a fine water-buck, no matter how big he is, provided you have a decent chance at the animal in question, besides running the risk of putting off your friend and spoiling his day's sport, to say nothing of one's own.

We had marked down this patriarch amongst water-buck in that very same way. Often when walking down the narrow footpath, all overhung with dripping grass as high as one's thigh, which does duty for a high road for all and sundry in these African solitudes, we had marked down this fine old bull-grey in colour, with his massive horns well separated in the graceful curve that an old bull carries, and which marks him out in the herd as one worth getting. We had several times remarked to one another that he was worth a little spare time to try for when we had had our surfeit of buffalo.

Thus rudely awakened by my "savage," who brings in a steaming cup of bovril at the same time, I lie awake for some ten minutes before I can prevail upon myself to leave the warm recesses of my "downy" for the chill morning air. A shooting camp is a place and an occasion for a lot of over-exercise and little sleep. Hard at work before dawn and all the morning, a short siesta (if any for some people) at midday, more 


\section{Big Game Shooting}

walking and shooting in the evening, and then a good dinner and lengthy chat till ten or eleven o'clock, puts one into a good humour and at peace with all the world; whilst seven hours' sleep"hogging it" as I have heard it expressed-is enough for most men when they are shooting hard. Those ten minutes in the morning, thinking over yesterday and its results, and the probable chances for to-day, are the best in the twenty-four. On Sundays an extra half-hour's think is almost the height of bliss. It must be remembered that in these high altitudes in East Africa the air is decidedly chilly in the early morning; so much so that in June and July out there, which correspond to our winter in England, there is often a touch of frost on the ground. Of course the sun soon clears that off, but a bucket of cold water rather makes one feel somewhat of a martyr at times.

We cross the river in the Berthon boat and start off. After five minutes' walking we are wet to the waist in the rank grass and undergrowth, sodden with dew as it usually is at break of dawn in the tropics.

Behind those bushes in front I expect to see my old friends, that herd of impalah which is always there at this hour of the morning, returning from their drink to get under the friendly shade of the giant umbrella thorn trees, which are part and parcel of the bush for some 


\section{Round Lake Natron}

distance along this side of the river. Sure enough there they are! Ghostly shapes-lithe and wiry - that stand and stare, partly from surprise, and partly from excitement, and then bound off wholly from excitement and joy that they as well as we are alive and well on such a morning. "Thanks, you may go; we don't want you. We know one another so thoroughly!" Never did either of us have a shot at our friends in that herd, and I rather believe that in the end they made up their minds that we were a gigantic farce, in spite of all their wild acquaintances' assurances that we were the very worst people in Africa, and sought for the blood, or rather the heads, of every animal around.

Nearing the place where we expected to meet our monster water-buck, we stopped and motioned the porters who accompanied us to sit quietly behind a bush. Silently and warily we advanced, with only one gun-bearer between us with a heavy rifle, in case of a charge from a belated buffalo or rhino that had been having a night out. The sky was getting pinker and pinker, the air colder and colder, as it does just before dawn, and the mist hung heavy over the swamp.

A reed-buck or two darted across our path, but we took no notice and crept on. A herd of waterbuck strolled across, feeding as they went, and our hearts beat loudly as this might be the lot we wanted. He was not there; so having waited 


\section{Big Game Shooting}

long enough for him to appear-the oldest will always come out of the grass last-we started forward again.

I thought it was not quite the right place, but we wanted no mistake, so with our hearts in our mouths still we went on. "We must get behind that big clump in front so as to be able to stand up under cover and have a good look beyond." "Right oh!" said he. Once there, we breathed again, straightened our backs, mopped our faces, brushed off the mosquitoes, took out our glasses, wiped them, and put them to our eyes. "By Jove! you're right, old chap! There he is!" And all by himself, daintily cropping the young grass shoots, every now and then raising his head in the air and sniffing round, stood "our" waterbuck, or so we fondly imagined him to be. We stared at him in admiration, standing with his lordly head raised erect, the personification of antelope life and strength, his shape and body like a Scotch red-deer, the old water-buck we knew so well, conspicuous in the fact that his horns were nearly straight.

"Cry!" said he. "Heads, says I. "Yours," moaned he. "Lucky devil!" Bang! went the rifle. "You fool," he shouted as the water-buck up with his head and bolted through the grass. Bang! went the second barrel; and there was an answering plunge on the part of our quarry "You've hit him!" 


\section{Round Lake Natron}

"Go on!" I shouted. "Let drive and knock him down before he gets into the swamp. We must have him!" My friend's rifle spoke, and again he lurched-badly this time-and disappeared. We sat down to give him time to stiffen and lie down before we followed him up. This is often necessary, as a wounded animal, if not pursued violently, when badly wounded, invariably lies down soon; and what with loss of blood and his nerves being unstrung, there he stays, till, being quietly approached, he affords a sitting shot, thereby enabling one to put him out of his misery instead of a long stern chase through the jungle, which usually ends in one losing him.

"Just time to smoke one cigarette before we follow him up, although I don't think he can have gone very far."

The sun was now showing over the top of Gelei to the south-east, and the mist hung all the heavier over the tepid waters of the Soda Lake. Everything was alarmed at the reports of the rifles: crashes in the reeds, the screaming of fisheagles, and the beat and whirr of strings of duck which were whistling round everywhere. When we had given him time enough we started carefully in pursuit. Blood everywhere, spattered on the broken reeds, showed us the trail. At one place the reeds had been battered down, and blood lay about in large gouts. "He took a bad 


\section{Big Game Shooting}

toss here evidently," said my companion; "loss of blood, I suppose."

He had kept on through this dense mass of matted vegetation in an extraordinary way, however, and we had covered some distance, but without proceeding at any pace to speak of, for fear of starting him off if he should be lying down. The tracks were now beginning to get mixed up with others, and I was afraid of losing him, so motioned one of the gun-bearers, a firstrate tracker, to go in front. After another fifty yards he suddenly stopped and stiffened, which somewhat surprised me, as if he had seen the wounded animal he ought not to have assumed the exact attitude he did. This was explained a moment after, as with a roar a lion bounded into the reeds and made off, grunting with annoyance. He had evidently been messing about within the fringe of reeds when the wounded water-buck, whose carcase lay on the ground, had stumbled into him, and had been instantly killed. He was, I suppose, hungry, so our inopportune appearance on the scene of action angered him.

Anyhow, there lay the water-buck - a real beauty, with a splendid head well over thirty inches, and the horns curving outwards so much as to be almost straight, their tips forming nearly an equilateral triangle with their length. However, there was no time then for congratulation, as the lion had to be followed "at once if not 


\section{Round Lake Natron}

sooner." And away we went. All we could do was to pursue the general course of his retreat, which was more or less sketchy, and hope for the best.

Now and again, when luck favours a man, and he knows, moreover, that his luck is " in," back it, and back it well! Spare no exertion, and follow it up. And it is on occasions like this that that jade "fickle Fortune" rewards one if one "plays up" one's luck.

She did us well now, as we tumbled out of the reed-bed slap on to a patch of sand, and it took my tracker the matter of a few seconds only to cast along up wind to the north to find the pugs of three lions in the ground. We hesitated a moment here, as we all knew there was one lion on the tapis, and so the tracks of three made us wonder if we were in reality after three, though only one had shown up, or whether they were another lot-say, an hour old. We decided, however, to follow them up faute de mieux. We backed our luck again! After some ten minutes' hard going, as the tracks were very plain on the damp ground, the tracker stopped. "Simba! simba! Tatu! tatu!" (three lions). "Wapi? Hyuko!"

But they had gone! Cursing, we ran hard, but only just in time to have a snapshot at a yellow flash disappearing behind a friendly bush into the jungle. To our unbounded disgust, they 


\section{Big Game Shooting}

had made off. No blood to be seen, which was hardly likely, as I doubted having hit the beast; and what made matters worse, we were now some little way from the swamp, and they had made off over hard, stony ground. Eagerly we started, working like niggers to pick up their trail, but all to no purpose. Luck had deserted us in a twinkling, as so often happens. We went on and on, separating and straggling all over the ground to try and find their pugs. It is no good bemoaning fate, so we metaphorically packed up our traps and set out for home. We consoled ourselves on the way by remembering that we had accounted for an emperor amongst waterbuck, which was, when all was said and done, a better morning's shoot than many and many another in the course of our experience of big game shooting in East Africa.

Our morning's trek had taken us some distance, and what with all the delays and excitement of tracking, the sun was well up, and it was now about eleven o'clock, so that we were pretty tired, having been awakened some seven hours earlier; and we walked homewards, not troubling ourselves, in single file, no one taking any care, talking loudly and discussing what "might have been."

Every animal in the jungle is enjoying his midday sleep by this time, and if not actually lying down in the shade of a friendly tree, is 


\section{Round Lake Natron}

standing under one dozing and lazily flicking off the flies with his ears and tail. As a matter of fact, one gets accustomed, however tired and worn one is, to keeping a sharp look-out in front, if not to each side, of the line of march.

"Hullo!" my friend exclaimed, "there are our old pals, the impalah!" Sure enough, there was a very fine buck, bigger than I had seen in the neighbourhood, and we had been there for some three weeks. "I don't think it can be the same herd," I said, "as they ought to be resting over by that old Wandorrobo village now. It must be another herd strayed down here, or else a single buck. It looks to me like the latter, as he's a bigger head than any herd-impalah I have seen here. Can you see any more?"

I think it must be intuition that teaches one habits of game, where to find them at odd times of day after one has been living in a certain district for any length of time. This latter factor most distinctly holds good, as by dint of hard work and sparing no pains to attain the end in view, as well as by keeping one's eyes very wide open in one's interviews with the hosts of local trackers who come into camp at all times of the day and night, one can collect endless information.

Whilst enjoying a comfortable smoke in the evening after dinner, one's "savage" approaches and says that a local pal of his wishes to talk. 


\section{Big Game Shooting}

Up he comes, and after inquiring towards one's welfare, asks what he can do for the "Bwana."

"Can you put me on to eland?"

"Certainly. If master starts an hour before dawn and marches hard for two hours-I will lead the way-towards the north; and you will be back in camp before the sun is half overhead with the finest eland you ever saw."

"Oh, but I can't possibly go out till midday."

"That simplifies matters, as if the Bwana will come out only half the distance towards the water springs to the north-east, I will show you the same herd lying under the trees they always go to at that time of the day, and it will make no difference."

"Then why did you advise me to start early?"

"Because, as we know Bwanas, they always like to start at the most uncomfortable time in the early morning, and sleep all day. It is the same!"

Of course one ought never to be taken in by the "biggest animal (of a kind) you ever saw." But as to locality and knowledge of the habits of different game, these denizens of the jungle are unrivalled. They know these things from their youth up; it has been ingrained in them ever since they were born, and is part of their education. They may be casual, but they appear much more casual than they really are. Make 


\section{Round Lake Natron}

friends with them, treat them well, and they will "do one proud," as the saying is.

On our return to camp after slaying the aforesaid impalah, which proved to be a single buck and an unusually large one at that, the first thing to be done was to change, bathe in the improvised bathing pool we had made by damming up the river with trees interlaced with thorn bushes, boulders, and mud, eat largely of the excellent fare provided by our Goanese cook (curry powder must invariably be taken on these shooting trips, as the rice part of the business fills up the cracks), and proceed to organize a small party of porters to wander out that morning and the early morning of the following day to scan the heavens for any signs of vultures or marabou storks over the scene of our adventure with the lions, just in case one of them might have been wounded by the snapshots. Birds are the surest sign in the East of the carcase of any defunct animal, wheeling round high in the sky, collecting other friends to the feast spread out for them below. Many and many an animal has been retrieved which had before been regarded as hopelessly lost by the never-failing "sign of the birds." It should also be remembered that a carcase found by means of the "sign of the birds" should be approached with extreme caution the next morning, more especially if the trees around be swarming with birds sitting in them, as it is quite probable 


\section{Big Game Shooting}

and more than possible that a lion or other beast of prey may be on the carcase, and have frightened the birds off the feed to the trees. At all events, never rush things. There is no such thing as time in the East. Every man's time is his own, except when columns on the warpath, marching through the jungle, have to meet one another at a certain place and time; then it is of paramount importance. But then, that is nothing to do with a shooting camp.

That night we made merry over the waterbuck, as it was a trophy worth getting; and I for one went to sleep in the "peace of Africa" as happy as a king. The day's work is done. Success has crowned our efforts. Surely this outdoor life of absolute freedom, when one has attained one's object, is preferable to a club chair in smoky, foggy old London, where so many say their happiest moments are spent, and where at the same time so very, very many have made the most egregious error of their lives. 


\section{TO NAIVASHA AFTER DUCK AND SNIPE}

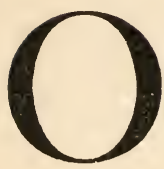

$\mathrm{NE}$ fine day, having made the necessary preparations in the shape of tents, cartridges, food, and the hundred and one things that appertain to duck-shooting -old boots, warm socks in heaps, sweaters, and the ordinary impedimenta that one cannot travel without-three of us seated ourselves at Nairobi station in the up train for Lake Naivasha.

It was a warm day in August, the IIth to be exact, as duck-shooting on Naivasha opens the next day, and having settled down in the comfortable carriage we proceeded to while away the time, whilst the train crawled up to the top of the Kikuyu escarpment overlooking the Great Rift Valley, with a novel and a whisky and soda. Higher and higher crept the train, at first through the cultivated land round Limoru, further and further till it reached the summit, winding its way through the cedar forests at the top of the range; and then a magnificent vista of mountain, forest, and plain, many thousands of feet below, broke on our eyes.

"But how in the world are we going to get 


\section{Big Game Shooting}

down there?" said the new-comer. "Oh! I suppose we don't go as far."

"Oh! yes you do: wait and see." And it was with amazing and almost dangerous (so it seemed) rapidity that the train plunged down through the forest passes, swinging round corner after corner, occasionally whisking with a subdued rumble over an iron bridge, all the time whizzing along at break-neck speed, till it drew up, half-way down the escarpment, at the station on the tiny plain, that seemed provided by nature for the buildings, tanks, and platform.

A shrill whistle is heard and off we go again, ever downward, to the plain three thousand feet below, until on rounding a corner and heading north-west again, Longonot appears towering on high on our left.

We are now on the floor of the Great Rift Valley, volcanic by nature and also in appearance. Longonot near by, and Suswa some fifteen or twenty miles towards the south-east, form excellent examples, being both extinct and therefore explorable, of the turbulence of this part of the globe in bygone times. They are only beaten by Menengai, which is far bigger and not so imposing, further up the valley, overhanging Nakuru station. Barren to their tops, they tower over the surrounding plain, and if one takes the trouble to scale their giddy heights one is rewarded by the sight of a mass of vegetation 
To Naivasha after Duck and Snipe at the bottom of their craters. The way down inside is dark and difficult, and the growth of trees so thick and impenetrable that different friends have told me that they have lost their way inside and have been obliged to stay in the gloomy recesses for more than a day at a time. The floor of these craters is quite warm, and, by the way, they all seem to swarm with guineafowl. Menengai is so big that one can be lost for days at a time at the bottom. This latter is the resort of innumerable rhinoceroses, with very fine heads withal, as well as being one of the feeding-places of the Laikipia elephants when they are moving about in their biennial trek. It is a difficult matter to get down, but quite a serious one to find one's way out, and they say the local rhino is very fearsome!

On goes the train. Naivasha is near by now, and from the carriage windows may be seen small herds of hartebeest, followed in quick succession by impalah and Grant's gazelle, with an ostrich or two in the background.

At last the lake looms into view, when one tops the last ridge, and the train rattles down the gentle incline to the station, situated near the lake, between it and the lower spurs of the Aberdare range, on a grassy plain sparsely covered with clumps of thorn trees, reaching for two or three miles to the Government Zebra Farm, on the Morendat River. A familiar figure awaits 


\section{Big Game Shooting}

us on the platform-broad in stature, happy in face, and ready to crack a joke and sing " Highland Mary" with the best. Ah! my friend, "always be merry and bright" is your motto as well as mine!

$U_{p}$ we went to the fort, where a good dinner awaited us, and the affairs of state and the following day's shoot were arranged.

Awakened in the morning, after breakfasting off the best, we repaired to the lake, intent on the numerous water-fowl we were to bring to book.

The plan of action is to line out, some on the bank and others wading through the reeds, and walk the birds up for some considerable distance, and then, whilst we are enjoying our lunch, the savage part of the population are dispatched some two miles further on to drive the reeds we have not disturbed back to us. Almost before we had cracked our last joke-some had not even thought of loading-the outside gun on the left in the lake spoke-"bang! bang!"--and down tumbled a couple of teal. The report echoed far out over the lake, resounding over the surface of the waters on this still, sunny day, and with a whirr, up got millions of teal and duck of all sorts. I imagined at first that we had disturbed the whole of the bird creation; but that idea was soon dispelled, as almost with every footstep a bang was heard somewhere down the line at 
To Naivasha after Duck and Snipe a duck getting up just in front. We naturally had to proceed very slowly to allow of the guns in the water keeping proper touch with those on terra firma; but still the sport went on. The air was full of duck, circling and wheeling round in big flocks, little flocks, and by twos and threes. On we went, with the birds settling, some in front and others behind, waiting to be shot at again. Now and again a fusillade opened on the right, on land, and on the question being passed down the line as to what they were shooting at, the answer came back, "snipe." The marshy, grassy bays reaching into the lake were swarming with them, and we took toll accordingly.

After some two miles of walking, during which the popping was fast and furious, we reached the big mimosa belt which ran down into the lake, and having safely negotiated the tree-trunk which did duty for a bridge, found luncheon-time had arrived.

The bag was counted, and the different species of duck duly admired at intervals between the beer and sandwiches. Spur-winged geese, Egyptian geese, pintail, pochard, a kind of wood-duck (apparently), mallard, a monster species of teal, as well as the ordinary kind, and a duck new to me, which had pinky feathers in the wing, and which was by far the commonest, were there, together with snipe that had been gathered, and we were correspondingly pleased. 


\section{Big Game Shooting}

However, we were not to rest long, as shortly our boss remarked that we ought to be "up and doing"; as the sight of the duck getting up at the far end and coming over us betokened that our savages had started in on their drive.

Quietly we took up our positions, wading slowly out to the farthest, most of us more than kneedeep in water, carefully selecting a thickish clump of reeds to hide behind. Bang! Down tumbled a duck, "pulled out of the skies," as the phrase has it. Soon the sport became fast and furious, quite a large number of duck, getting up behind us on account of the noise of the fusillade, coming over and making us keep our eyes open all round.

At last all was over and we trudged home, three sportsmen walking up the snipe ground and on the way back adding some five couple to the bag.

The day following was voted an off day, as work had to be attended to, and the duck allowed a rest to settle down again and regain their composure of mind after the slating they had received; but we visitors, who were in luck, were allowed to go out in boats and try our luck on the islands towards the western end of the lake and the reeds round the edge there, far away.

On a sunny morning, as before, we embarked with two trusty savages, who said they knew all about it; and away my friend and I went. We 
To Naivasha after Duck and Snipe were smoking and discussing the scenery and things in general, as well as the species of duck that swam on the surface of the water and wheeled round, when, with a snort and a grunt, out of a big reed-bed rushed a hippopotamus. It was interesting to me as it was the first I had seen in East Africa, and he was quite near at hand. It was also a most unusual place to find one, as it was so close to the station with its whistling and shunting of trains.

However, there he was, fairly caught after his night out, half plunging, half swimming out of the reeds till he got into deep water. The sun glistened on his wet back as he bolted in a terrible fright towards his home at the west end, whither we were going. We were so taken by surprise that we both stared for a moment, and then $\mathrm{my}$ friend seized a rifle and fired twice. I did the same in a twinkling. We both missed him, the bullets cutting the water up beyond him.

Another long shot or two, but he got off, and well he deserved it. I was very much struck by the rapidity with which he got through the water, his huge bulk making the spray fly on all sides, but the speed with which he moved was marvellous.

The sport was desultory, as all the duck were resting and feeding in yesterday's reeds round the edge ; but now and again we "struck ile" in the marshy parts of the islands. However, the 


\section{Big Game Shooting}

day was bright and beautiful and the weather warm, and it was in reality more our fault than the ducks', that we did not get a better bag. We had started out lazy and we slacked it thoroughly. On the way home it was impossible not to notice the beauties of nature around.

To the south and west the Mau escarpment, towering some four thousand feet high, purple and shimmering in the heat reflected off the sunlit lake. The sun almost down, and then edging the tips of the mountains with golden outlines. A sapphire sky above. Longonot standing out towards the south in sweltering brown and purple. We lay like logs, and bid the boatmen pull us home through it all. Through broad bays chokefull of water-lilies and other aquatic flowering plants, with the invariable, never-ending banks of papyrus fringing the whole, and towards the east the sunlit, placid waters, dotted all over with the feathered tribe. Content as we were with everything and ourselves, this was another example of the "peace of Africa."

I will summarize the third day's sport by saying that we combined shooting in the reeds as on the first day, and had natives in boats as well, so as to keep the birds fairly on the move, and profited accordingly; and break off into another day's duck and snipe shooting, in which I was the sole participant, this time on Lake Olborlossat.

We had had a very long and trying march 


\section{To Naivasha after Duck and Snipe}

over the northern slopes of the Aberdares, and at the end of it all a steep descent into the valley of the upper waters of the Gilgil River, which runs into Lake Naivasha. The Subugo Ololdian Mountain bounds one side, and the Aberdares, with Mount Olligollum towering over all, the other. The lake was full of hippo, which could be easily made out from the mountain-side, but which were quite un-get-at-able, I found out on investigation, owing to the matted reeds not being thick enough to allow of one's walking over them, and so being able to approach the clear water-way.

I had a hasty meal off a box of sardines as usual on arriving on the site of the proposed camp for the night, and sallied out with my gun to kill time, whilst the camp was being pitched and lunch prepared, and something for the pot as well.

The duck seemed very tame, and I tried a stalk. When I was quite close up he got up, flapping lazily, and was duly knocked down. I thought it rather odd and tried again, with the same result. The same thing happened again and again, and at last I tumbled to it.

I was in for a real big bag if I went about it in the proper way, and, moreover, there would be no waste, as the porters were short of food and would eat everything I managed to shoot.

A rush for camp, followed by a heavy feed, set me up, and with any amount of cartridges I 


\section{Big Game Shooting}

started in at the duck. The whole of the porters in camp volunteered to a man when I had only half got through my harangue, which spoke volumes, as they were all tired after the hard march. Their business was to drive the shallow part of the lake up to me. I may explain that there was some three miles of water to drive, all wadeable, with hardly any resting-place on the far side and none in the middle. It was a long lake about one quarter of a mile, or less, wide, that was wadeable.

The first thing that struck me was the quantities of snipe in the air, though as they were miles high I did not shoot, but thought the more. They might perhaps be got at afterwards!

Well, the hundred and twenty porters made a solid line and waded and shouted. The duck were so tame that at first they flew only a few yards and pitched. I saw this wall of men advancing with the duck in front in the distance and thought it would be a mere slaughter. To cut a long story short, the duck came over me as the beaters approached, and it was rather like shooting at clay pigeons to begin with, but the birds got enlivened up a bit at the banging and came better afterwards. In the middle of the proceedings I sent off a boy, who was standing by to pick up birds, with a message that half the beaters were to go out of the lake, retrace their footsteps, and do the whole thing over again. As 


\section{To Naivasha after Duck and Snipe}

it turned out, this move just about doubled my bag, as lots of duck had flown back behind the first line of beaters, and so were almost all brought up again over me.

When the first lot of porters who had been driving the birds arrived, their excitement was unbounded at seeing the carcases floating all round, and it was with great difficulty that they were induced not to make too much noise. At length they were pacified by the approach of more duck, which were shot and fell among them, and then, and only then, they were made to crouch in quiet amongst the reeds till the drive was over. At the end of all things the babel was stupendous as they dashed about collecting the killed. Tumbling over one another, shouting, cursing, each in his own language, fighting now and again over a wounded bird that some one had secured after a wild race for it, the hubbub fairly woke the echoes, and it was not until after I had lifted up my voice and proclaimed that, as usual, the slain would be taken home and piled in front of my tent for distribution that order was maintained.

This must be the invariable rule in every shooting camp, that any animal after being skinned and cut up should be carried back to camp, piled in front of one's tent, and parcelled out to all and sundry over the camp-fire in the evening, when the sergeants and headmen of the porters had made their reports. Any stealing of 


\section{Big Game Shooting}

meat is usually made a severe offence, as it leads to such ill-will and heart-burnings in the savage mind.

Whilst the bag was on its way home to camp I walked the boggy ground nearer the mountain for snipe, and had excellent sport. Both the fan-tail and pin-tail were there in quantities, and I got two jack-snipe into the bargain, which rather pleased me, as I had no idea that this species abounded in any number. The result of the day's sport would be hard to estimate, as a good many duck would be sure to have been stolen and eaten on the quiet, but I know that I divided that night lots of duck and snipe amongst the men, after keeping an exceedingly liberal supply for our own use. It was the best day's duck and snipe shooting I have ever enjoyed to my own cheek. 


\section{A DAY ON THE GERMAN BOUNDARY}

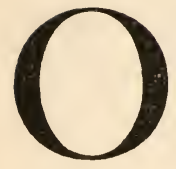

$\mathrm{NE}$ day at the beginning of February, I906, I found myself in camp on the River Guaso Nyiro, one of the back camps on the line of communications of the Anglo-German Boundary Commission, where I had been sent in charge of the escort. A long chain of camps was the order of the day. Parties used to go out a long way, some fifty miles ahead, to build beacons of wood covered with canvas, for the wielders of the prismatic compasses, theodolites, and the general impedimenta used for surveying purposes, to work their wicked will with. Thrown out on each side came the actual sketchers of the country, who went over every foot of ground, working on the general data and points that had been fixed definitely by the advance parties. Last, but by no means least, came those who had charge of the food depôts and main camps, whose duty it was to send along provisions as they were required, do all the dirty work of shifting camps and clearing off old ones - in a word, the general factotums.

As may be imagined, one had a certain amount 


\section{Big Game Shooting}

of leisure and time on one's hands, which was invariably employed in shooting and improving one's mind in natural history. The other officer, who was with me almost all the time, I am glad to say, held the same views as myself with regard to sport in general, from the "sport of kings" to shooting a bull buffalo, or a rat hunt. In his own language, he was "all over anything." Many and many a happy day we spent together in consequence.

Our camp was pitched on a grassy bend of the Guaso Nyiro in the open. The river was fringed with shady trees, and there were some big clumps at the neck of the bend also, which our men and porters made good use of to lie and cook their food under in shelter from the heat. The open ground stretched for about three-quarters of a mile, and ended in a belt of bush-jungle about one mile broad, merging into open sandy desert further on. There was very little game in this bush, except a few impalah and wart-hogs, and an occasional wandering buffalo that had been caught by the sun on his way back to his lair in the swamp two miles off. In the sandy desert everything swarmed. The other bank of the river was very similar, but six miles away towered the bold bluffs and crags of the continuation of the Mau plateau, and there was more swampy ground towards the south. The camp itself was composed of a series of grass 


\section{A Day on the German Boundary}

huts, some thirty feet long by fifteen across, with a plentiful current of air passing under the roofs, some twenty feet high. Open at each end, they were cool in the heat of the day and comfortable at night. Each officer had one to himself, and others were built for the soldiers composing the escort, and for the porters as well.

One fine day my friend and I crossed the river in the early dawn, before light, in our Berthon boat, to trek back to our last camp and see if everything had been properly taken away and that nothing remained. We had sent a tent on in front of us in which to pass the midday heat.

This march would, as was invariably the case, be combined with shooting, and by starting long before dawn we hoped to get quietly to the outer edge of the bush and some way into the open plain beyond to try for the monster rhino which inhabit these parts. I may say I am firmly convinced that the rhino here carry bigger horns than in a good many other places, because owing to the heat they never appear by day, and therefore they have to do their feeding in the plains by night, and so they are seldom, if ever, seen. My reason for saying this is because in other higher, and therefore cooler, districts one tumbles on to eight to ten in a morning on occasions, that is to say, on the march up till twelve or one o'clock in the afternoon.

Well, we arrived, sat down in the open, and 


\section{Big Game Shooting}

waited silent for a time, hoping for the best and talking in whispers till the dawn broke. A large object, evidently alive and some one hundred yards away, immediately attracted our attention, but its huge bulk in the shadow gradually dwindled in the light of day to the ungainly form of the humble wildebeest. We were so annoyed with him on finding that he was not the object of our search, that he went off, galloping and wildly whirling his tail, into oblivion for all we cared.

On we trekked for some distance, marching parallel about two miles apart, each with our small posse of gun-bearers and porters, so as to give greater scope for our eyes and to cover more ground in which to find game.

At last I sighted a cock ostrich, then two, then two more, hens. Taking liberties as usual, to see how near one can get by walking casually by oneself, I found myself about four hundred yards off, and at once thought of a stalk. Another hundred yards in a crouching position, with a fifty yards' crawl on my stomach, brought me close enough, as there was little or no more cover, and I should only have pumped myself worse than I was already, and therefore should have been too shaky to shoot. A breather for five minutesduring which time the ostriches seemed to have an idea something was up-enabled me to recover my breath enough to draw a fairly steady bead on one of the cocks; but it only shows what a lot 


\section{A Day on the German Boundary}

stalking takes out of one when I say that the shot of my life followed on the press of the trigger, and I found on reaching him (he had sprung high into the air and fallen plumb on the spot) that I had hit him bang in the head. I need hardly say that a two-inch bull at 250 yards is Bisley marksmanship, but that, when one is aiming at his body some three feet underneath, is little short of a monstrous and shocking fluke. However, all's well that ends well, and my sister-in-law says she admires his feathers very much!

After a couple of porters had tied him on to a stout pole and shouldered him back to camp, on we went, and the next thing I struck was a solitary black-tailed gnu-the wildebeest of commerce. They seem to have a certain sense of humour, do these curious brutes, as they allow one to get within some three hundred yards, staring hard all the time, before they bolt off at a hard gallop, whirling their tails round and round like a catharine-wheel. This performance repeated often is quite enough to break one's heart, and means that it will be just as well to give up the chase and leave him alone, as there is no getting near him for hours afterwards that day. On the other hand, view him in the distance tail-on, and give up all other ideas but the bagging of him, take infinite pains, and stalk until you are blue in the face and "sweating blood" from every pore, get behind any decent semblance of a bush, wait and whistle from some 


\section{Big Game Shooting}

eighty yards away, and he is as good as yours. If he doesn't see you, and you miss him, he won't gallop twenty yards before he waits and looks round for you - and bear in mind that any animal shot at without previous warning is just as likely to gallop straight at you as in any other way. At the second shot, of course, he is yours, as the first shot will have told you any errors in elevation or direction. What I have just described actually happened, except that he galloped quite close to my bush before he stopped, and I began to wonder whether I was going to be run down or not, and then when I hit him in the heart (as I found out on cutting him up), he gave a rush and only missed the bush by a hair's breadth before he fell dead. So number two species was disposed of.

The next thing we saw was a herd of six giraffes, which I had not had the opportunity of observing quite close till then. The proverbially sharp eyesight of these animals enabled them to spot us long before we saw them, but on this occasion they saw my friend first, some one and a half miles from me. The wind being right, they headed straight for me, and I was somewhat alarmed by hearing the ping of a bullet in rather close proximity long before I heard the report of his heavy cordite rifle. Down we went at once to see what would happen. Giraffe move at what appears to be a slow lumbering gallop, with never 


\section{A Day on the German Boundary}

more than one leg in the air at one time, rolling all the while like a rocking-horse in a south-east gale, and still with a very aristocratic "don't worry me" gait. They came quite close to my position, to within some forty yards or so, when suddenly up we stood; they did not seem to bother themselves in the slightest, and, except for changing direction in a flash like a polo pony, still kept on at the same speed, lolloping over the ground in the easiest manner. On examining their tracks, however, they were quite half as long again as a sixteen-hand horse at full gallop. I didn't want one, so I didn't shoot, and they went off moderately happy, I presume.

That brought us near camp, or rather near our feeding-place, as we had previously made up our minds to return to the flesh-pots of last night instead of camping out. I am sorry, but I cannot understand the excitement of camping out down the Thames or anywhere else, and making oneself thoroughly uncomfortable for one night, or even a week, when one has got a more or less decent house to live in. Most picnics are pretty bad, unless one's best girl is there to amuse one! I suppose five years of discomfort in that line, hot or cold, wet or fine, teaches one that a cheery fireside with no scorpions or other noxious insects to invade one's bedclothes, and no minor worries of any kind, is the best thing after all is said and done. 


\section{Big Game Shooting}

However, lunch was almost ready, and after a soothing drink of something in the gin line, and scrambling out of our clothes into the river close by, we sat down as hungry as hunters to a delicious bit of liver (from this morning's wildebeest) and bacon, and the various other tinned delicacies which we had brought with us. I am afraid my readers' mouths might water too much if I set forth the whole menu-so we will cut that short.

A short siesta and a general look round proved that all was well, and we dressed again for the return journey. At about four o'clock on the way back I spotted a fine Grant's gazelle, which I determined to have a try at. I may here wander from my point for a moment again to say that if one does a march in the morning and back again the same day, it is very highly improbable that the same animals will be met with in returning as in going; also that one may see different species altogether in the evening from what one met with in the morning. The great reason for this is that herds of game are always on the move, and feed all day, resting at intervals, in huge circles. On the other hand, it is most probable that if you go over the same ground again the morning after that you will find the very same herd-not species but herd-that you saw there twenty-four hours before. This I am practically certain of, having proved it over and over again in different districts 


\section{A Day on the German Boundary}

one hundred and two hundred miles apart and more. I will say this chiefly seems to be the case with antelopes rather than other game, and at the same time by no means holds with single or solitary animals who have been chucked out by their former friends and have no further aim or object in life than to "eat, drink, and be merry," according to their own individual lights.

To return to my "moutons." That Grant was rather a brute and led me no end of a dance, but I secured him in the end by working him down amongst some bushes and then bluffing him that I was behind one certain bush when I wasn't. It was an amusing and interesting stalk, and goes to prove that by taking trouble and sparing no pains anything that is worth while doing is worth doing well - very well indeed.

On we went, and just before sunset-the sun always sets about six o'clock on the Equator-we spotted a marabou stork hovering over the defunct carcase of this morning's ostrich, which had been skinned by the porters to save them carrying home "overweight." Being in tremendous form in the shooting line from the day's experience, I thought I would start in at him. A marabou must be chanced at about two hundred yards, and he is not such a very big mark at that when all is said and done. However, being comparatively fresh, lying at full length on my "bread-basket" 


\section{Big Game Shooting}

- which is, I understand, the correct term used in pugilistic encounters by champions of the ringand drawing a steady bead, he plumped down in due course, bringing to an end a real good sporting day. I have made no mention of the numbers in the different herds of the game we saw, but it will, I hope, be understood that their name was legion. In a game country in the African wilds it is almost impossible to put into writing the countless myriads of game. One might almost be said to be spoilt for shooting big game after shooting in these paradises. One certainly often goes out amidst these innumerable herds without firing a shot, and comes home empty because one does not want any male head or animal for the sake of shooting it. One learns at first discrimination, which comes by experience, and from that is certain to be bred a higher term or use of the word "sport," which is used every day by the million and really thoroughly understood by so few. To my mind the term "sport" and "playing the game" are synonymous. "Live and let live" is another well-known proverb, and almost comes under the same heading.

Back to camp in the heart of Africa-with the gleam of the camp fires, the hum of the entourage of soldiers and servants, the fire-flies flitting through the trees like tiny electric lights, a sentry challenging now and again-with a good and tried friend who understands one, talking 


\section{A Day on the German Boundary}

comfortably in the warmth of a tropical paradise -with the remembrance of "her" at home; and then to bed, with perhaps the roar of the king of beasts in the far distance. Quite good enough, thank you! 


\section{THE PRESERVATION OF BIG GAME}

I

AM very much interested in the above and should like to make a few remarks in support of it. There are certain points which might be taken seriatim.

(I) Disease. - This is practically confined to rinderpest, at least in Uganda, British East Africa, and Somaliland, which countries I propose to deal with more especially. Years ago the ravages of this dreadful epidemic practically wiped out buffalo, eland, and greater kudu. Now, thanks to international game laws and the consequent protection of animals by means of large reserves, this has been stayed, insomuch as rinderpest is in a very fair way to have been stamped out, and the different species of game which are chiefly affected by it have had a chance to recover, and certainly their numbers are very rapidly increasing again, to the unbounded satisfaction of "all sportsmen. What could be more sad than that these princes amongst African big game should disappear from the face of the earth!

I have seen buffalo skulls bleached by the sun 


\section{The Preservation of Big Game}

and wind, probably thirty years old, lying about in large quantities in places that were well known to be swarming with these splendid animals years ago and now are comparatively denuded of them.

Round the base of Kilimanjaro I came on these evidences more than once, and again on the Northern Guaso Nyiro in Laikipia. In the former place they are rapidly increasing, I am glad to be able to state, more especially round Lake Natron, the Soda Lake, which is more in German territory than British. The bush in the latter place is too thick, and I had not sufficient time then, to go into the question thoroughly, but there were ample evidences all down the river-bank that there were plenty of buffalo there. Eland were also afflicted, as is well known, but as they are more nomadic in their habits and wander about the open plains, not depending on thick bush for cover, their remains are not seen so frequently or in such numbers as the former. When I got to North Somaliland in I90I I was told that greater kudu, which are very local there, inhabiting the Golis Mountains altogether, were just thinking about recovering from rinderpest, which had spread up as far north as that. I take it that any bovine antelope, or in the latter case the finest and biggest in the country, was attacked by this epidemic more than any other, which is curious. One never hears of the 


\section{Big Game Shooting}

water-buck, Grant, or dhero having been decimated in the same way.

I have often killed antelopes in both these countries simply smothered in bots. The botfly, as is well known, burrows in under the skin, lays its sac of eggs and climbs out, leaving these eggs to hatch on their own. They begin itching and the animal starts scratching the place and biting it, with the consequence that the maggots cover him all over-mouth, feet, and everything. Then they are swallowed in natural sequence, and the animal consequently gets scraggy and poor. Tsetse do not seem to affect any wild animal, nor does African coast fever or redwater, which plays such havoc amongst the cattle. This is strange, because rinderpest started amongst cattle and affected the game, so why do not the other two diseases do likewise?

(2) Camivora.-The hunting dog is by far the worst of all animals for killing game. A pack of these brutes-one cannot call them anything else-gets on to the track of an antelope and the unfortunate animal is pursued up hill and down dale till he is pulled down by his relentless foes. When a pack is sighted they should be slaughtered en masse-mere killing is too good for them. One longs for the old days of rack and thumbscrew to torture them with. Lions and the spotted pard take their toll no doubt, but in a more gentlemanly manner as a rule, 


\section{The Preservation of Big Game}

except when the latter lies up near a station, as they so often do, to feed on one's maiden-aunt's yapping lap-dog! That is the worst of the leopard, that besides the above-mentioned cur he takes it into his head to carry off one's best spaniel or retriever when trotting along beside one when one is absolutely unprepared. Sitting on an overhanging branch of a tree or in a bush beside the path, he makes one spring and the gruesome deed is done.

Carnivora must be shot in all game reserves, as otherwise $(a)$ they will kill too much game; (b) the antelopes, etc., being attracted there by the quiet and the presence of other species in very large quantities, so much more will the carnivora be attracted on account of the scarcity of game outside; when their presence will tend to drive out all these animals to be shot elsewhere, thus making what ought to be a sanctuary a holy terror after all. This could easily be done by granting previously tickets for a limited time each to sportsmen who would not overstep the mark, and it would not, I think, disturb the game unduly.

(3) The Black Man. - The chief hunting tribes in East Africa are the Wakamba, Wanyamwezi, who show ancient traces of cannibalism in their teeth, which they still file to a sharp point, and the Wandorrobo. The latter are from time immemorial professional hunters, and 


\section{Big Game Shooting}

are very shy of the white man and civilization in general. They are of very low caste, and are looked down upon by all their confrères almost as much as the Midgan of Somaliland, who are generally reckoned as the lowest of the low. Till the late game laws came into force, the Wakamba carried on a great trade in rhino horns, to which they still attach a great commercial value if they can be properly and successfully smuggled. The numbers of rhino skulls and skeletons that lie about Ukamba are extraordinary, and afford a suitable and excellent resting-place for the ubiquitous vulture, who sits like Patience on a monument wondering in which direction his next meal will sniff from. The Wandorrobo has nothing else to live upon except on what he kills, and I think they really are sportsmen. One comes across their villages on the Tana for instance, or hidden deep in the forests, from the Mau escarpment over Laikipia to Lake Baringo. Tiny huts, tucked away from the ken of man, composed of a few vertical boughs with a parlous roof of other branches, by no means calculated to keep out rain, but apparently simply huddled together for sympathy and "pro bono publico." They live on what nature provides, as is also shown by the honey-pots stuck up in the trees. A $\log$ of wood some five feet long by three feet across is hollowed out and the ends blocked up, with a little hole for the bees to get in and out of 


\section{The Preservation of Big Game}

They are visited periodically, and the contents are excellent at the end of a long march if one can by good luck make friends with the owners. Dirty and uncivilized to a degree, these people are the least known of all East African savage life. No, I think they are Nature's children and almost thorough sportsmen after their own lights. The Somali Midgan usually hunts with a pack of mongrel pie-dogs, and his chief object is the oryx. The skin covering the withers of this handsome antelope is a marketable article all over the country, as, being extremely thick, it is exclusively used for making the little round shield to be seen on every man's arm in the country. Some are embossed in rude patterns, others painted in red and black inside with sentences from the Koran, and others so splendid, according to their owners' ideas, that they are always kept clean and nice, tied up in "merikani" for high days and holidays. These are sportsmen too to a certain degree, and anyhow it would be almost impossible to prevent their oryx-hunting propensities, on account of the shield which, I repeat, is part of the equipment of the native gent and oi $\pi 0 \lambda \lambda o^{\prime}$ into the bargain. When shooting in Somaliland or in the wilds of East Africa it is indispensable to attach a Midgan or Wandorrobo, respectively, to one's personnel, as having gained their confidence and therefore their friendship (a state of bliss usually 


\section{Big Game Shooting}

attained through the medium of a gift of large quantities of raw meat), one will be told of localities for certain animals otherwise unthought of, or perhaps unreachable owing to a desert march without water, and facilities arranged for the bringing of them to book which might have been deemed impossible beforehand; added to which as general utility servants, for the sending of messages, and fagging all over the surrounding district, they are invaluable.

The professional black hunter is the only real nuisance to be dealt with as regards indiscriminate slaughter of game. He knows he is a nuisance, and he knows he is tabooed, and so he makes his plans accordingly, so as not to be collared redhanded in more senses of the word than one. All are well known, all should be absolutely barred. The word should go out north, south, east, and west that any black professional hunter without a licence should be brought into the nearest station and very severely dealt with. Furthermore, and more important still, no more licences should be granted to any one in the shape of a professional black hunter after a certain date. Very few of these blackguards, would be hurt, as the comparatively small number of individuals who could not gain a better livelihood trading-they know the ways of the world well enough-or better still entering their names on a list at the various coast ports to be taken 


\section{The Preservation of Big Game}

on as accredited shikaris to sportsmen proceeding up country to shoot, would be very slight. They would then live a life of comparative ease in their master's camp, with the certainty of getting their pay at the end of the trip, and would be benefiting the white man into the bargain, which, when all is said and done, is the be-all and endall of the black man.

After the word has gone forth, with plenty of time to make their terms and come to their senses and do what they are told, let them be severely dealt with, so as to stamp out the black professional in any and every country where the international game laws are in force. It would be the beginning, and in a great part the end, of the emancipation of African big game from the indiscriminate slaughter inflicted by the untutored brain of the African savage in modern civilized times.

(4) Lastly; the White Man! - There are several kinds of white man! As "Tommy" says, "All beer is good, but some beer is better than other beer!" There are some men who "know" and do it, others who "know" and don't do it, others who don't know but wish to goodness they did, and are always striving and slaving to play the game, and can't simply because they aren't told. How would it be to arrange a comprehensive meeting of some dear and real old sportsmen who have "been and seen" and know all about 


\section{Big Game Shooting}

it? Gather them together, those who have roughed it and shot the world over. Could not we have the benefit of their combined efforts and brains to elaborate a code of laws for the pursuit and final bagging of big game? Africa has of late become a fashionable country for shooting in. Crowds of sportsmen go there year in year out. All come back to Old England rapturous in their praise of the country and the shooting to be obtained in the most beautiful climate in the world. On the Equator, too! Who would have imagined it ten years ago? More and more are making up their parties to go and shoot there every year. Let us have some good broad-minded shooting rules laid down in black and white for the guidance of those who don't know. Most of them would "sell their souls" (as the expression goes) to know. It would go a very long way indeed towards the protection of big game all over the world. Whilst they are at it, i.e. this committee-meeting of sportsmen, whose names one could hazard a very good guess at, they could legislate for the icy peaks of the Pamirs and the Altai Mountains, as well as the Central Provinces and the African Equator, even comprising far-away New Zealand and its stags, with the Rockies into the bargain.

Reserves are all very well in their way, and are the only possible means up-to-date. They are certainly absolutely respected by all and 


\section{The Preservation of Big Game}

sundry, but the time will soon come when game will get scarce, now the world is being so tremendously over-populated. Take South Africa for example. They tell me that there was once a time within the ken of modern man when the country teemed with vast herds of antelope of all sorts. Millions of elephant abounded there, and everything that one can imagine to do with Africa. Look at it now! Where are they all? Gone-like the North American bison. That is the simile I want. Countless millions, so common that no attempt was made to preserve them, and the one poor little herd that now is kept alive in the Yellowstone Park is so important to all the world that its births, marriages, and deaths are duly published in The Times.

Take time by the forelock. Let us get in any little wedge we can before it is too late, to heave up the whole stupendous block before it sinks into oblivion. We don't want to have to fall back on the British Museum, or at least our offspring does not, to go and gape and see what used to be in days gone by. If things are common let them be kept in multitudes instead of being wiped out. The international game laws existent are very good, but certain animals, at present none too numerous, might very well be added in some small degree to the list of prohibitions. The thin end of the wedge might be started by making some animals, if not exactly barred for a term of 


\section{Big Game Shooting}

years, more expensive to shoot. Some might be taken off the front of the licence and put on the other side of $i t$, with an extra $£_{3}$ or $£_{5}$ for permission to shoot one or even two. I don't think anybody can growl at the liberal allowance "to be killed" in the East African or Somali schedules, both of which I have before me. As a matter of fact, one does not shoot anything like the number one is allowed, because that would be slaughter. We want good heads and specimens, not numbers. It is not a rabbit shoot! On the other hand, settlers in some parts are allowed to kill off all the game on their land, with reservations. This is following apparently in the same footsteps as South Africa years ago. What will result? "La débâcle!"

Taking into account the game reserves as they are at present, the Somali reserves on the Golis Mountains amply protect the lordly greater kudu. Farther south, the Jubaland and Sugota reserves do their work well, whilst the Athi Plains reserve is splendid, and affords a safe harbour for any ship in distress. Who that has been up the Uganda Railway has failed to note with admiration the countless herds of antelope, with an occasional rhino or lion standing absolutely unconcerned at the sight of the passing train? They know the train is their best friend, so why worry!

Laikipia has, I believe, been added since, now 


\section{The Preservation of Big Game}

that the Masai has gone there. They are not a hunting tribe. More power to their elbow! The Lake Shirwa and Elephant Marsh reserves, in British Central Africa, much farther south, near the Zambesi, finish the roster on the East Coast, and do untold good.

To wind up and sum up the whole question into the proverbial nutshell: Disease can't very well be helped, and the slaying of animals by carnivora can't be helped at all, as they will work their wicked will at all hazards, and all the laws of the prophets can't stop it. The black man nuisance can, to a great extent, be avoided by stringent laws and the withdrawal of licences, whilst to crown the lot, let us have a code of rules for stalking and shooting, properly published and of wide-world fame, for the use of the novice as well as of the past master. One lives and learns, and there are many others who want to do the same, to say nothing of those who will follow and are not even yet thought of.

It seems now quite time that I should "dry up," as it is elegantly termed, for the reason I can find no more to say about the animals which I have brought under this brief discussion.

The animals that have been described are those that may be met with ordinarily in any shooting trip in East Africa; some are common as dirt, others rare; but if the latter are sought 


\section{Big Game Shooting}

for in the localities named, one has a fair chance of coming across them, though whether they are actually brought to book is a different bag of tricks.

One hears the same old lament from every shooting party on its return: "Yes, but I saw for half a minute a really splendid —, but, just like my luck, missed him."

One of the animals I can only casually mention is the beautiful sable antelope, because I know nothing about him. The only place he is found in is the Shimba Hills, some twenty-five miles from Mombasa, but they are few and far between, and their heads are small, besides which the locality is difficult, and there is usually a lack of water.

The sable is a little smaller than the roan, but is very similar in shape and style, though with smaller ears and larger horns. The body colour is very different-black in the bull and dark brown in the cow, with the belly white and the face marked much like the roan's, but with more white.

If the visitor intends returning to Europe by the Nile and Cairo, which is rather a popular route nowadays, there are other animals he may meet on the way, notably :-

The Uganda Kob.

White-eared Kob.

Mrs. Gray's water-buck (a most beautiful animal). 


\section{The Preservation of Big Game}

\section{The Harnessed Antelope.}

The very rare and difficult-to-find Situtunga, who buries himself in water, leaving only his nose above the surface.

And possibly one or two more.

I fancy, however, that shooting on the way down the Nile is a lengthy business if not almost impossible.

My object will have been achieved if these few words may be found to be of use to the big-game sportsman in East Africa, as well as the photographs, so that he can identify any animal that comes across his path at a glance.

"Morituri te salutant" (but kill outright). 


\section{EAST AFRICA PROTECTORATE}

QUEEN'S REGULATIONS UNDER ARTICLE 45 OF "THE EAST AFRICA ORDER IN COUNCIL, I897," AND ARTICLE II OF "THE EAST AFRICA ORDER IN COUNCIL, I $897 . "$

\section{Preservation of Game}

I. IN these Regulations-

"Hunt, kill, or capture" means hunting, killing, or capturing by any method, and includes every attempt to kill or capture: "Hunting" includes molesting.

"Game" means any animal mentioned in any of the Schedules.

"Public Officer" means a European officer in the public service of the East Africa or Uganda or Zanzibar Protectorates, or on the Superior Establishment of the Uganda Railway, or an officer of one of Her Majesty's ships on the East Africa station.

"Native" means any native of Africa, not being of European or American race or parentage.

"Settler" means a person for the time being resident in the Protectorate not being a public officer or a native.

"Sportsman" means a person who visits the Protectorate wholly or partly for sporting purposes, not being a public officer, settler, or native.

"Collector" means the principal civil officer in charge of a district of the Protectorate.

"Schedule" and "Schedules" refer to the Schedules annexed to these Regulations. 


\section{Game Regulations}

\section{General Provisions}

2. No person, unless he is authorized by a special licence in that behalf, shall hunt, kill, or capture any of the animals mentioned in the First Schedule.

3. No person, unless he is authorized by a special licence under these Regulations, shall hunt, kill, or capture any animal of the kind mentioned in the Second Schedule if the animal be $(a)$ immature, or $(b)$ a female accompanied by its young.

4. No person, unless he is authorized under these regulations, shall hunt, kill, or capture any animal mentioned in the Third Schedule.

5. The Commissioner may, if he thinks fit, by Proclamation, declare that the name of any species, variety, or sex of animal, whether beast or bird, not mentioned in any Schedule hereto, shall be added to a particular Schedule, or that the name of any species or variety of animal mentioned or included in one Schedule shall be transferred to another Schedule, and, if he thinks fit, apply such a declaration to the whole of the Protectorate, or restrict it to any district or districts in which he thinks it expedient that the animal should be protected.

6. No person shall within the Protectorate sell, or purchase, or offer or expose for sale, any ostrich eggs, or any head, horns, skin, feathers, or flesh of any animal mentioned in any of the Schedules, unless the ostrich or animal has been kept in a domesticated state, and no person shall knowingly store, pack, convey, or export any part of any animal which he has reason to believe has been killed or captured in contravention of these Regulations.

7. If any person is found to be in possession of any elephant's tusk weighing less than I I lbs., or any ivory 


\section{Big Game Shooting}

being in the opinion of the Court part of an elephant's tusk which would have weighed less than II lbs., he shall be guilty of an offence against these Regulations, and the tusk or ivory shall be forfeited unless he proves that the tusk or ivory was not obtained in breach of these Regulations.

8. No person shall use any poison, or, without a special licence, any dynamite or other explosive for the killing or taking of any fish.

9. Where it appears to the Commissioner that any method used for killing or capturing animals or fish is unduly destructive, he may, by Proclamation, prohibit such method or prescribe the conditions under which any method may be used; and if any person uses any method so prohibited, or uses any method otherwise than according to the conditions so prescribed, he shall be liable to the same penalties as for a breach of these Regulations.

IO. Save as provided by these Regulations, or by any Proclamation under these Regulations, any person may hunt, kill, or capture any animal not mentioned in any of the Schedules, or any fish.

\section{Game Reserves}

II. The areas described in the Fifth Schedule hereto are hereby declared to be game reserves.

The Commissioner, with the approval of the Secretary of State, may by Proclamation declare any other portion of the Protectorate to be a game reserve, and may define or alter the limits of any game reserve, and these Regulations shall apply to every such game reserve.

Save as provided in these Regulations, or by any such Proclamation, any person who, unless he is authorized by a special licence, hunts, kills, or captures any 


\section{Game Regulations}

animal whatever in a game reserve, or is found within a game reserve under circumstances showing that he was unlawfully in pursuit of any animal, shall be guilty of a breach of these Regulations.

\section{Licences to Europeans, Ec.}

12. The following licences may be granted by the Commissioner or any Collector, or such person or persons as may be authorized by the Commissioner, that is to say:-

(1) A sportsman's licence ;

(2) A public officer's licence; and

(3) A settler's licence.

The following fees shall be payable for licences, that is to say, for a sportsman's licence, 750 rupees, and for a public officer's or a settler's licence 150 rupees.

Provided that a public officer's licence may be granted for a single period of fourteen consecutive days in one year on payment of a fee of 30 rupees.

Every licence shall bear in full the name of the person to whom it is granted, the date of issue, the period of its duration, and the signature of the Commissioner, Collector, or other person authorized to grant licences.

The applicant for a licence may be required to give security by bond or deposit, not exceeding 2,000 rupees, for his compliance with these Regulations, and with the additional conditions (if any) contained in his licence.

A licence is not transferable.

Every licence must be produced when called for by any officer of the Protectorate Government, or by any officer of the Uganda Railway specially authorized in writing by the Commissioner.

In granting licences under these Regulations, a Collector or any person authorized to grant licences shall 


\section{Big Game Shooting}

observe any general or particular instructions of the Commissioner.

13. A sportsman's licence, and a public officer's licence respectively, authorize the holder to hunt, kill, or capture animals of any of the species mentioned in the Third Schedule, but unless the licence otherwise provides, not more than the number of each species fixed by the second column of that Schedule.

The holder of a sportsman's or public officer's licence granted under these Regulations may by the licence be authorized to kill or capture additional animals of any such species on payment of such additional fees as may be prescribed by the Commissioner.

I4. A settler's licence authorizes the holder to hunt, kill, or capture animals of the species and to the number mentioned in the Fourth Schedule only.

I5. A public officer's licence shall not be granted except to a public officer, and a settler's licence shall not be granted except to a settler; but a sportsman's licence may be granted to a settler.

I6. When a licence similar to a public officer's licence under these Regulations has been granted in the Uganda Protectorate, that licence shall authorize the holder to hunt, kill, or capture game in the East Africa Protectorate, in all respects as if the licence had been granted in the East Africa Protectorate, provided that such licence shall be first indorsed by a Collector or other authorized officer of the East Africa Protectorate: provided also that any authority to kill or capture additional animals or any animals not permitted under the corresponding East Africa licence shall be void.

I7. Where it appears proper to the Commissioner for scientific or administrative reasons, he may grant a special licence to any person, not being a native, to kill or capture animals of any one or more species mentioned 


\section{Game Regulations}

in any of the Schedules, or to kill, hunt, or capture, in a game reserve, specified beasts or birds of prey, or other animals whose presence is detrimental to the purposes of the game reserve, or, in particular cases, to kill or capture, as the case may be, in a game reserve, an animal or animals of any one or more species mentioned in the Schedules.

A special licence shall be subject to such conditions as to fees and security (if any), number, sex, and age of specimens, district and season for hunting, and other matters as the Commissioner may prescribe. And in the Uganda Railway zone, whether included in the game reserve or not, it shall be lawful to kill or capture any beast of prey.

When the Collector or Assistant Collector, or other European officer of the Protectorate Government, in a district comprising a game reserve, is the holder of a public officer's licence, the Commissioner may grant a special licence authorizing the officer to hunt, kill, or capture, in the game reserve, such animals as may be allowed by his public officer's licence.

Save as aforesaid, the holder of a special licence shall be subject to the general provisions of these Regulations, and to the provisions relating to holders of licences.

18. Every licence-holder shall keep a register of the animals killed or captured by him in the form specified in the Seventh Schedule.

The register shall be submitted as often as convenient, but not less frequently than once in three months, to the nearest Collector or Assistant Collector, who shall countersign the entries up to date.

Any person authorized to grant licences may at any time call upon any licence-holder to produce his register for inspection. 


\section{Big Game Shooting}

Every person holding a sportsman's licence shall likewise, before leaving the Protectorate, submit his register to the Deputy-Commissioner.

If any holder of a licence fails to keep his register truly he shall be guilty of an offence against these Regulations.

19. The Commissioner may revoke any licence when he is satisfied that the holder has been guilty of a breach of these Regulations or of his licence, or has connived with any other person in any such breach, or that in any matters in relation thereto he has acted otherwise than in good faith.

20. The Commissioner may, at his discretion, direct that a licence under these regulations shall be refused to any applicant.

$2 \mathrm{I}$. Any person whose licence has been lost or destroyed may obtain a fresh licence for the remainder of his term on payment of a fee not exceeding one-fifth of the fee paid for the licence so lost or destroyed.

22. No licence granted under these Regulations shall entitle the holder to hunt, kill, or capture any animal, or to trespass upon private property without the consent of the owner or occupier.

23. Any person who, after having killed or captured animals to the number and of the species authorized by his licence, proceeds to hunt, kill, or capture any animals which he is not authorized to kill or capture, shall be guilty of a breach of these Regulations, and punishable accordingly.

24. Persons in the employment of holders of licences may, without licence, assist such holders of licences in hunting animals, but shall not use fire-arms.

The holder of a sportsman's or public officer's licence while engaged in hunting animals mentioned in the Schedules shall not be accompanied by more than 


\section{Game Regulations}

one person provided with a settler's or native's licence.

In any case of a breach of this Regulation, the licence of every licence-holder concerned in the breach shall be liable to forfeiture, and such licence-holder shall be guilty of an offence.

25. The Commissioner or any person authorized by him in that behalf, may, at his discretion, require any person importing fire-arms or ammunition that may be used by such person for the purpose of killing game or other animals to take out a licence under these Regulations, and may refuse to allow the fire-arms or ammunition to be taken from the public warehouse until such licence is taken out. Save as aforesaid, nothing in these Regulations shall affect the provisions of "The East Africa Fire-arms Regulations, I 896."

\section{Restrictions on Killing of Game by Natives}

26. When the members of any native tribe or the native inhabitants of any village appear to be dependent on the flesh of wild animals for their subsistence, the Collector of the district may, with the approval of the Commissioner, by order addressed to the Chief of the tribe or Headman of the village, authorize the tribesmen or inhabitants, as the case may be, to kill animals within such area, and subject to such conditions as to mode of hunting, number, species, and sex of animals and otherwise, as may be prescribed by the order.

An order under this Regulation shall not authorize the killing of any animal mentioned in the First Schedule.

The provisions of these Regulations with respect to holders of licences shall not apply to a member of a tribe or native inhabitant of a village to which an order under this Regulation applies. 


\section{Big Game Shooting}

Save as aforesaid, the general provisions of these Regulations shall apply to every native who is authorized under this Regulation, and a breach of any order shall be a breach of these Regulations.

27. The Collector of a district may, with the approval of the Commissioner, grant a licence, similar to a sportsman's or settler's licence, to any native, upon such terms as to fees and other conditions as the Commissioner may direct.

\section{Legal Procedure}

28. Where any public officer of the East Africa Protectorate thinks it expedient for the purposes of verifying the register of a licence-holder, or suspects that any person has been guilty of a breach of these Regulations, he may inspect and search, or authorize any subordinate officer to inspect and search, any baggage, packages, waggons, tents, building, or caravan belonging to or under the control of such person or his agent, and if the officer finds any heads, tusks, skins, or other remains of animals appearing to have been killed, or any live animals appearing to have been captured, in contravention of these Regulations, he shall seize and take the same before a Magistrate to be dealt with according to law.

29. Any person who hunts, kills, or captures any animals in contravention of these Regulations, or otherwise commits any breach of these Regulations, shall, on conviction, be liable to a fine which may extend to $\mathrm{I}, 000$ rupees, and, where the offence relates to more animals than two, to a fine in respect of each animal which may extend to 500 rupees, and in either case to imprisonment which may extend to two months, with or without a fine.

In all cases of conviction, any heads, horns, tusks, skins, or other remains of animals found in the posses- 


\section{Game Regulations}

sion of the offender or his agent, and all live animals captured in contravention of these Regulations, shall be liable to forfeiture.

If the person convicted is the holder of a licence, his licence may be revoked by the Court.

30. Where in any proceeding under these Regulations any fine is imposed, the Court may award any sum or sums not exceeding half the total fine to any informer or informers.

Repeal, etc.

31. All previous Regulations as to the killing of game in the Protectorate are hereby repealed.

32. The forms of licences appearing in the Schedule hereto, with such modifications as circumstances require, may be used.

33. These Regulations may be cited as "The East Africa Game Regulations, 1900."

34. These Regulations are hereby declared urgent.

(Signed) ARTHUR HARdinge, Her Majesty's Commissioner and Consul-General.

Mombasa, October 7, Igoo.

Approved :

(Signed) LANSDOWNE,

Her Majesty's Principal Secretary of

State for Foreign Affairs. 


\section{Big Game Shooting}

\section{AN ORDINANCE}

ENACTED BY HIS BRITANNIC MAJESTY'S COMMISSIONER FOR THE EAST AFRICA PROTECTORATE

$$
\text { (L.S.) D. STEWART, }
$$

Commissioner.

Mombasa, August 2, I904.

$$
\text { No. I I of } 1904
$$

\section{Game}

IT is hereby enacted as follows :-

I. This Ordinance may be cited as "The Game Ordinance, 1904," and shall be read as one with "The East Africa Game Regulations, I900," hereinafter referred to as the principal Regulations.

2.-(I) An occupier of land may take out a landholder's game licence for the sum of 45 rupees, and may also take out a similar licence at the same fee for any person permanently employed by him in connection with the land.

(2) The licence shall only permit game to be hunted, killed, or captured on land in the occupation of the holder of the licence or of his employer.

(3) The licence shall not authorize animals mentioned in the first Schedule or the females or young of animals mentioned in the second Schedule to the principal Regulations to be hunted, killed, or captured.

(4) The licence will permit the animals mentioned in the third and fourth Schedules to the principal Regulations to be hunted, killed, or captured, and the limitation on the number of animals to be hunted, killed, or captured therein contained will not apply. 


\section{Game Regulations}

(5) Except as otherwise provided in this section, the holder of a landholder's game licence will be subject in all respects to the provisions of the principal Regulations.

3. Where a person holding a landholder's game licence holds also a settler's licence, animals killed or captured on his own land under his landholder's licence shall not count towards the number of animals he is entitled to kill under his settler's licence.

4. The Commissioner may, in special cases, grant, at a fee of 150 rupees, a sportsman's licence to a person entitled to take out a settler's licence, but such licence shall be deemed to have been issued under the principal Regulations.

5. Not more than one fourteen-day licence shall be issued to the same public officer between the 3ist March of one year and the 3Ist March of the next year.

6.-(I) All licences issued under this Ordinance or under the principal Regulations shall expire on the 3 Ist day of March next after the date of issue.

(2) The provisions of this section shall not apply to licences now in force, nor to fourteen-day licences issued to a public officer.

(3) The Commissioner may, on the expiration of licences now in force, issue to the holders thereof, if they desire to renew their licences, temporary licences of the same class expiring on 3 Ist March, at such fees and with liberty to hunt, kill, or capture such number of animals mentioned in the third and fourth Schedules as the Commissioner may think fit.

7.-(I) Ostrich eggs, heads, horns, bones, skins, feathers, or flesh of any non-domesticated animals mentioned in the Schedules to the principal Regulations 


\section{Big Game Shooting}

may be sold in the following cases and under the following conditions :-

(a) If they form part of the estate of a deceased person, by the Administrator-General or personal representative of such deceased person, with the consent of the Court granting probate or administration, and on payment of such fee as the Court directs, not exceeding 20 rupees ;

(b) If they have been forfeited, by the order of the Commissioner or of the Court by which they have been declared to be forfeited.

(2) The purchaser shall in each case be given a certificate specifying the articles and declaring that they have been lawfully sold under the provisions of this Ordinance, and such certificate shall be evidence that the purchaser has not obtained the goods in contravention of the principal Regulations.

8. Any person who is found in possession of any cow ivory shall, unless he prove that the ivory was not obtained in breach of the principal Regulations, be guilty of an offence against this Ordinance.

9. The Commissioner may by Proclamation remove any animals from any of the Schedules to the principal Regulations. Such Proclamation may apply to the whole of the Protectorate, or to any province, district, or other area.

I0. The Schedules annexed to this Ordinance shall be substituted for the third and fourth Schedules to the principal Regulations.

I I. Any landholder, or his servant, finding an animal mentioned in the Schedules to the principal Regulations spoiling his crops or doing damage to his holding, may kill the same if such act is necessary for the protection of his crop or holding, but he shall give notice thereof to the collector of the district without delay, 


\section{Game Regulations}

and the head, horns, tusks, and skin shall be the property of His Majesty, and shall be dealt with as the Collector may direct.

12. Animals mentioned in the Schedules to the principal Regulations killed or captured by the holder of a licence under the principal Regulations upon private land at the invitation of the occupier, shall not count towards the number of animals that person is entitled to kill under his licence.

13. No person shall be entitled to hunt, kill, or capture animals mentioned in the Schedules to the principal Regulations on private land in the occupation of another person other than his employer unless he is the holder of a licence under the principal Regulations.

14. Any person committing a breach of this Ordinance, or guilty of an offence against this Ordinance, shall be deemed to be guilty of an offence against the principal Regulations.

I 5. The Commissioner may by rule prescribe the forms of licences issued under the provisions of this Ordinance.

16. The following enactment is hereby repealed to the extent mentioned in the column:-

Game Ordinance 1903 . No. 4 of 1903 . The whole Ordinance.

D. StEwart,

Mombasa, August 2, 1904.

Commissioner.

\section{SCHEDULES *}

FIRST SCHEDULE

Animals not to be hunted, killed, or captured by any person, except under Special Licence.

I. Giraffe.

2. Mountain Zebra.

* These Schedules may contain the names of some species or varieti s not found, or only occasionally found, in East Africa. 


\section{Big Game Shooting}

3. Wild Ass.

4. White-tailed Gnu (Connochotes gnu).

5. Eland (Taurotragus).

6. Buffalo.

7. Elephant (female or young):

8. Vulture (any species).

9. Secretary-bird.

IO. Owl (any species).

I I. Rhinoceros-bird or Beef-eater (Buphaga), any species.

12. Ostrich (female or young).

\section{SECOND SCHEDULE}

Animals, the females of which are not to be hunted, killed, or captured when accompanied by their young, and the young of which are not to be captured, except under Special Licence.

I. Rhinoceros.

2. Hippopotamus.

3. Zebra (other than the Mountain Zebra).

4. Chevrotain (Dorcatherium).

5. All Antelopes or Gazelles not mentioned in the First Schedule.

\section{THIRD SCHEDULE}

Animals limited numbers of which may be killed or captured under a Sportsman's or Public Officer's Licence.

Kind.

Number allowed.

I. Elephant (male) . . . . . 2

2. Rhinoceros . . . . . . 2

3. Hippopotamus . . . . . 2

4. Zebras (other than the Mountain Zebra). 2 


\section{Game Regulations}

Kind.

5. Antelopes and Gazelles-

Class $\mathrm{A}$ -

Oryx (Gemsbuck Callotis or Beisa) . 2

Hippotragus (Sable or Roan) . . 2

Strepsiceros (Kudu) • • . . 2

6. Colobi and other fur Monkeys. . . 2

7. Aard-Varks (Orycteropus) . . . 2

8. Serval . . . . . . . 2

9. Cheetah (Cynoclurus) . . . . 2

Io. Aard-wolf (Proteles). . . . . 2

I I. Ostrich (male only). . . . . 2

I2. Marabout . . . . . . . 2

I3. Egret . . . . . . . 2

14. Antelopes and Gazelles-

Class B-

Any species other than those in Class A Io

I 5. Chevrotains (Dorcatherium) . . . Io

FOURTH SCHEDULE

Animals, linnited numbers of which may be killed or captured under a Settler's Licence.

Kind.

Number allowed.

1. Hippopotamus

2. The following Antelopes and Gazelles only-

(i.) Grant's Gazelle.

(ii.) Thomson's Gazelle.

(iii.) Hartebeest (Bubalis and Damaliscus).

(iv.) Impala (Aipyceros).

(v.) Reedbuck (Cervicapra).

(vi.) Duiker (Cephalophus).

(vii.) Klipspringer (Oreotragus).

(viii.) Steinbuck (Rhaphiceros).

(ix.) Waterbuck (Cobus). 


\section{Big Game Shooting}

(x.) Wildebeest (Gnu) Connochates (except the white-tailed species).

Five animals in all in any calendar month, made up of animals of a single species or of several; provided, however, that not more than ten animals altogether of any one species shall be killed during the period for which the licence is available other than Grant's Gazelle, Thomson's Gazelle, and Hartebeest (Bubalis and Damaliscus).

3. Serval

\section{FIFTH SCHEDULE}

\section{Game Reserve}

The areas bounded as follows :

I. An area bounded by-

I. The north-eastern limit of the Uganda Railway zone from the Tsavo River to the Athi River.

2. By the left bank of the Stony Athi River from the point where it is crossed by the Uganda Railway to the point intersecting a line drawn from the summit of Donyo Sabuk to the summit of Kijabi Peak.

3. By a line drawn from the summit of Donyo Sabuk through the summit of Kijabi Peak to its point of intersection by the eastern boundary of the Uganda Protectorate.

4. By the eastern boundary of the Uganda Protectorate from the last-named point to its point of intersection by the frontier of the German East Africa Protectorate.

5. By the Anglo-German frontier from its point of intersection by the Uganda Protectorate boundary to the point where it is intersected by the southern boundary of the Masailand district. 


\section{Game Regulations}

6. By a line drawn from the last-named point to the source of the Tsavo River.

7. By the left bank of the Tsavo River from its source to its intersection by the Uganda Railway.

II. An area bounded by-

On the north by the 3 rd parallel of north latitude.

On the east by the 39 th meridian of longitude.

On the south by the northern boundary of the Kenia district of the Province of Ukamba.

On the west by the boundary between the East Africa and Uganda Protectorates.

\section{SIXTH SCHEDULE}

No. I.-Sportsman's Licence (Fee 750 rupees), or Public Officer's Licence (Fee I 50 rupees)

$A$. B., of

, is hereby licensed to hunt, kill, or capture wild animals within the East Africa Protectorate for one year from the date hereof, but subject to the provisions and restrictions of "The Game Regulations, 1900."

[The said $A . B$. is authorized, subject to the said Regulations, to kill or capture the following animals in addition to the number of the same species allowed by the Regulations, that is to say :-

Fee paid (Rupees).

Dated this

day of

, 1900.

(Signed)

Commissioner [or Collector]. 


\section{Big Game Shooting}

No. 2.-Settler's Game Licence (Fee I 50 rupees).

C. D., of

, is hereby licensed

to hunt, kill, or capture wild animals within the district of the East Africa Protectorate for one year from the date hereof, but subject to the provisions and restrictions of the "The Game Regulations, 1900."

Dated this

day of

, 1900

(Signed)

Commissioner [or Collector].

SEVENTH SCHEDULE

Game Register

\begin{tabular}{l|l|l|l|l|l}
\hline Species. & Number. & Sex. & Locality. & Date. & Remarks. \\
\hline & & & & & \\
& & & & & \\
\end{tabular}

I declare that the above is a true record of all animals killed by me in the Protectorate under the Licence granted me on the I9.

Passed

(Signed)

190

(Signature of examining officer.)

List of game for which an extra fee is charged and 278 


\section{Game Regulations}

which is subject to alteration by order of H.M.'s Commissioner from time to time.

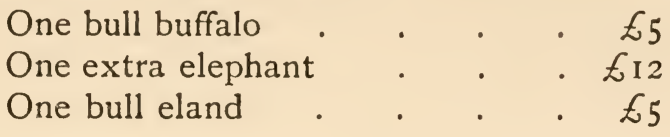

REGULATIONS FOR THE PROTECTION

OF WILD ANIMALS IN THE

GERMAN EAST AFRICAN PROTECTORATE, IST JUNE, I9O3.

Subject to Paragragh 15 of the last issue of the Game Regulations (Constitutional Law Book, 1900, s. 812) in connection with the order of the Chancellor of June Ist, I89I (Riebow, s. 326), an immediate abolition of all Game Laws governed thereby is ordered, and the following substituted :-

A. General Regulations holding good for Forcigners and Natives alike.

Par. I. One or more local regulations may be laid down, possibly within each civil or military district, for the preservation of wild animals in every shooting reserve, applying alike to every one. These will be promulgated as usual by official intimation within each district throughout German East Africa. In isolated districts elephant hunting may be forbidden from time to time in any determined territory. This needs the previous sanction of the Government, and is to be made known through the Official Announcer.

Par. 2. On plains with buildings, or fields, plantations, and indulgences, hunting is only to take place with the consent of the possessor.

Within the territory, in which the Governor permits 


\section{Big Game Shooting}

the practice of hunting, capturing, or shooting wild animals to certain persons, hunting may be carried on only by agreement with those certain persons entitled to so hunt, capture, or shoot there.

For the privilege of hunting, capturing, or shooting wild animals, the permission of the police is needed through the medium of a shooting licence.

For every licence a fee of ten rupees is to be paid.

Par. 3. All officers of the imperial districts, military and civil stations, are authorized to make out and issue these licences.

Par. 4. Game licences are valid for only the same calendar year in which they are made out. They will be made only in the name of the person entitled to them, and are not transferable.

Par. 5. The licencee must carry his licence with him.

Par. 6. The licence is to be shown on request. The administrating magistrates and their subordinates are authorized to control this within their districts.

Par. 7. Whoever loses his licence, and can testify that he owned one, will pay two rupees only for the making out of a duplicate.

Par. 8. The following persons may be refused a licence, who:-

(a) In the previous five years have committed an offence against the Game Regulations ;

(b) In the previous five years have been punished for committing an offence against property; or

(c) Are in arrears with the payment of shooting fees.

Par. 9. The applicant for a licence who has not his permanent abode in the country may be required by 


\section{Game Regulations}

the magistrate to give as deposit a security not exceeding 500 rupees. This security applies equally to those paying shooting fees as well as for fines for which the holder of a game licence may possibly be mulcted, and for the cost of law proceedings.

Par. 10. The hunting, capturing, or shooting of the following animals is forbidden :-

I. Giraffe. 4. Chimpanzees. 7. Secretary-birds.

2. Zebra. 5. Ostriches. 8. Owls.

3. Eland. 6. Vultures. 9. Kites.

The permission of the Governor may be obtained to kill or capture single specimens of these animals for taming or scientific purposes.

Par. II. The hunting of young or female game is, if possible, to be avoided. The buying and selling, or offering for sale, of any elephant's tusks under five kilogrammes in weight is prohibited.

Par. 12. Fishing with dynamite or other explosives, or poison, is forbidden.

Par. I3. The capturing of animals for trade purposes is only allowed by the special permission of the Governor.

Par. 14. All infringements of the Game Regulations of the Ist June, 1903, will, if they are not punishable according to the law of the German Empire, be punished with fines up to 450 rupees. In all cases of a conviction for breaking these regulations, the unlawful trophies and the game licence are handed over on withdrawal of the arms and ammunition.

Par. I 5. For killing a full-grown lion a bonus of twenty rupees will be paid to the killer.

For a full-grown leopard a bonus of ten rupees will be paid on handing over the fresh skin with claws and head. The skin can be repurchased for from three to five rupees. 


\section{Big Game Shooting}

If killed by means of the traps for beasts of prey, placed free in certain places by order of the Government, the bonus amounts to only ten and five rupees respectively.

\section{B. Special Regulations for Foreigners.}

Par. I6. For hunting, capturing, or shooting the following species a further fee is payable and is distributed as under:-

One elephant . . IOO rupees or one tusk.

One rhinoceros . . 30 rupees.

$\left.\begin{array}{l}\text { One hippopotamus } \\ \text { One buffalo }\end{array}\right\} \cdot 20$ rupees each.

One wildebeeste

One hartebeeste

One water-buck

One kudu

3 rupees each.

One oryx

One Colobus monkey

One Marabou stork

All other antelopes

and gazelles. . I rupee each.

The hunting, capturing, or shooting of beasts of prey and monkeys (with the exception of Colobus monkeys), of wart-hog, crocodiles, and reptiles, is also permitted without a licence.

Par. I7. On each licence (Formula A) blank spaces for game killed will be found for guidance, in which the number killed, with the imposed shooting fee of the various animals, is to be registered.

Par. 18. The licences, with the exception of the matter contained in Paragraph I, hold good for the whole country.

Par. 19. All district officers, collectors, and officers 


\section{Game Regulations}

of an independent military station, as well as their subordinates, are authorized to request to have the game registers laid before them at any time within their own districts.

Par. 20. Any person showing an incorrect return on his game register will, provided that no higher punishment is imposed by the Imperial Criminal Code, be dealt with under Paragraph I4.

Par. 21. The payments of shooting fees will be controlled by those authorities by whom the licence is granted.

Control can be assigned by request of a holder of a licence to another control office, which in this particular instance is to be endorsed on the licence.

This assignation of a licence to another control office, if it is to be feared that-

(a) Control of the game register of the sportsman cannot in sufficient measure be exercised; or

(b) A conviction will not arrive in the hands of the new control office before the Ist January,

can be cancelled.

Par. 22. At the end of the year, or after giving up hunting, the sportsman is required to render his game register, duly signed, to be examined, and the licence has to be handed in to the Corresponding Control Office for the purpose of correcting any errors.

If, by the Ist April of the following year for which the licence holds good, any error in the game register is not made good by the aforesaid sportsman, he will, without further appeal, be required to pay a fine of Ioo rupees without prejudice to the rights of the Control Office. 


\section{Big Game Shooting}

If a higher sum is due as a shooting fee than is shown on the game register, this will become payable.

The Control Office shail remind the possessors of the licences which it controls as soon after the expiration of the calendar year as possible, as far as the addresses are known, of the rendering of the game register, concerning wrong returns, unless the sportsman through the non-receipt of this reminder be freed from the regulations of this paragraph. In this case the Controller of the shooting fees and of the licence fee (Par. 2) will account afterwards for the mistake according to published orders in the administrative procedure.

\section{Special Regulations for Natives.}

Par. 23. By "hunting" in this case only hunting by means of the use of fire-arms is meant.

Hunting with spears, bows and arrows is generally allowed to natives without obtaining a licence.

Par. 24. Hunting is only permitted in the district within which the holder of a licence is settled.

A game licence holds good only for the district in which it is made out.

Par. 25. The killing and capturing of beasts of prey, wart-hog, monkeys, crocodiles, reptiles, and birds, with the exception of those mentioned in Paragraph 10 , is allowed without a licence.

Par. 26. The killing and capturing of elephants is only allowed by special permission of the authorities, which must be endorsed on the licence. This permission can only be granted to recognized and dependable persons.

For each elephant killed 100 rupees or one tusk are to be delivered to the Government.

Par. 27. Hunting parties may not consist of more 


\section{Game Regulations}

than six persons, each of which has to take out a licence.

These licences will bear similar numbers, viz.: 9a, $9 \mathrm{~b}, 9 \mathrm{c}$, etc.

Par. 28. Hunting elephants with poisoned spears or arrows, as well as hunting by means of fire, nets, or pitfalls, is prohibited.

Par. 29. The District Magistrates are authorized, in case of famine in isolated provinces, to allow the killing or catching of animals, with the exception of elephants and those mentioned in Paragraph ro, at stated times, without a licence. In this case hunting by means of nets is allowed. The same permission can be granted to villages if the prosperity of their crops is endangered through damage done by wild animals.

Par. 30. Hunting with breech-loading rifles or guns is prohibited.

This order, as well as all others for natives, includes all Askaris (soldiers, of the Police and of the Protectorate troops).

Par. 31. On the making out of a licence to every native, all rules applying to him by this Ordinance are to be read out and explained to him.

Dar-es-Salan, June ist, r 903.

(Signed) The Imperial Governor, GRAF VON GOTZEN. 


\section{Big Game Shooting}

\section{FORMULA A}

\section{A. For Foreigners. Control Office}

Licence No

Valid from ist January to 3 Ist December, I 9

for

The holder is entitled to hunt in the German East African Protectorate, having regard to the Regulations of the "Protection of Wild Animals Ordinance."

\begin{tabular}{ll|l|l}
\hline $\begin{array}{l}\text { The shooting of the follow- } \\
\text { ing is prohibited. }\end{array}$ & $\begin{array}{c}\text { Assigned at the Control } \\
\text { Office. }\end{array}$ & Date. \\
\hline Giraffe & & & \\
Zebra & & & \\
Eland . & & \\
Chimpanzees . & & \\
Ostriches & & \\
Vultures & & \\
Secretary-birds & & \\
Owls &
\end{tabular}

Signature of Holder

For this Licence a fee of ten rupees is to Duty be paid.

Stamp.

Signature or Stamp of the issuing Officer

N.B. - For shooting list and protection money tariff, see over. 



